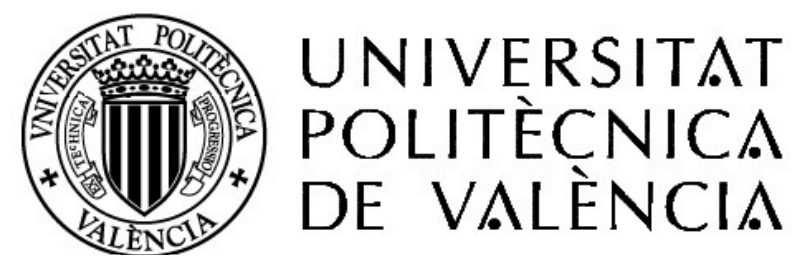

Departamento de Dibujo

Facultad de Bellas Artes de San Carlos

\title{
LA ENSEÑANZA DEL DIBUJO ARTÍSTICO EN CHILE: 1797-1858
}

\author{
por \\ Ignacio Villegas Vergara
}

Director de Tesis

Profesor Doctor Carlos Plasencia C.

2008 

A mis hijas Natalia y Valentina. A mi hijo Vicente. 

Agradezco a Carlos Plasencia C, por la experiencia aportada a esta investigación, a Ivón Isabel Ferreira, por sus comentarios, críticas y correcciones, a Josefina Olivos, Paulina Ramos y Danilo Espinoza por su paciencia en ayudarme con los textos e imágenes. 



\section{INDICE}

I. INTRODUCCIÓN

I.1. Justificación del tema

I.1.1. Antecedentes y estado actual del tema

I.1.1.a. Inexistencia de investigaciones sobre la materia

I.1.1.b. Importancia de conocer y comprender el clima político y social que rodeó la formación de cursos de Artes Plásticas

I.1.1.c. Importancia de las primeras iniciativas de enseñanza del dibujo ... 21

I.1.1.d. Existencia de mitos y errores históricos acerca del dibujo y las Bellas Artes en Chile

I.1.2. Esquema de las razones que justifican esta investigación

I.2. Delimitación del tema 25

I.2.1. Delimitación de contenido ......................... 25

I.2.2. Localización espacio-temporal …............ 26

I.3. Objetivos de la investigación

I.4. Hipótesis, metodología y plan de trabajo ................ 28

I.5. Plan inicial del tratamiento de la cuestión _..... 31

I.6. Delimitación conceptual de las materias abordadas ... 32

I.6.1. Enseñanza ............................................... 33

I.6.2. Dibujo .................................................... 40

I.6.3. Tipos de dibujo para esta investigación ............ 43 
II. CONTEXTO HISTÓRICO DE LA FORMACIÓN DEL PRIMER CURSO DE DIBUJO EN CHILE _ _ 59

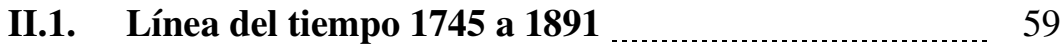

II.2. El mundo europeo 63

II.3. España 70

II.4. América del Sur 72

II.4.1. $\quad$ Aspectos geopolíticos ................................. 72

II.4.2. Aspectos culturales _..... 74

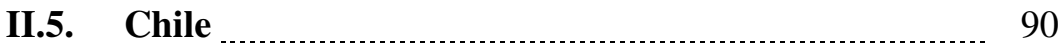

II.5.1. Aspecto geopolítico …............................ 90

II.5.2. Aspectos culturales _...... 95

III. ORIENTACIONES ESTÉTICAS EN CHILE EN EL PERIODO ESTUDIADO 99

III.1. En la arquitectura $\quad 99$

III.2. En Bellas Artes ............................................... 100

IV. ESTADO DE LA ENSEÑANZA EN GENERAL Y DEL DIBUJO EN PARTICULAR, EN CHILE HACIA FINES DEL SIGLO XVIII

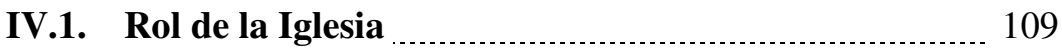

IV.2. Actuación de los gobiernos en la enseñanza .............. 112

IV.3. La enseñanza del dibujo en Chile en el siglo XVIII .... 119 
V. MANUEL DE SALAS Y LA ENSEÑANZA DEL DIBUJO. . 123

V.1. Biografía 123

V.2. Manuel de Salas, influencias políticas y morales: análisis de sus lecturas

V.3. Otras influencias relevantes en Manuel de Salas 152

VI. LA ACADEMIA DE SAN LUIS, PRIMERA INSTITUCIÓN QUE IMPARTE UN CURSO DE DIBUJO EN CHILE

VII. DESARROLLO DEL DIBUJO EN LA NUEVA REALIDAD CHILENA DEL SIGLO XIX

VII.1 El Instituto Nacional y el dibujo del natural

VII.2. La enseñanza del dibujo en Chile después de 1828 199

VII.3. Creación de la Academia de Pintura 202

VIII. CONCLUSIONES

VIII.1. Respecto a los mitos fundacionales: confusiones $y$ errores históricos sobre el origen de las Bellas Artes $y$ el dibujo en Chile, $y$ la influencia extranjera 213

VIII.1.1. Arte y Artesanía 214

VIII.1.2. La "influencia" francesa 216

VIII.1.3. La influencia española

VIII.1.4. La influencia de Palomino y Campomanes en Chile 
VIII.2. Dos aportes de Manuel de Salas al dibujo en Chile _... 219

VIII.2.1. Crea en Chile el primer curso de "Dibujo del Natural" y una metodología para su enseñanza

VIII.2.2. Incorpora en la enseñanza la relación entre arte (dibujo) y ciencia

VIII.3. Una casualidad y el curso de dibujo

VIII.4. Estrategia para el financiamiento de la Academia de San Luis

VIII.5. Una manera distinta de enseñar

VIII.6. El Instituto Nacional: ideas de Manuel de Salas y la enseñanza transversal

VIII.7. Bajo perfil del dibujo en la era republicana

VIII.8. Manuel de Salas impacta en las formas y contenidos de la enseñanza del arte en el siglo XIX en Chile

IX. REFERENCIAS BIBLIOGRAFICAS

IX.1. Autores en libros, revistas, anales, tesis y catálogos impresos

IX.2. Documentos electrónicos

IX.3. Periódicos 
IX.4. Documentos en el Archivo Nacional de Chile ............ 249

IX.4.1. Fondo Antiguo _......... 249

IX.4.2. Catálogo Claudio Gay .................................. 251

IX.4.3. Catálogo Colección Ministerio de Educación ... 252

IX.4.4. Catálogo Colección Ministerio del Interior ....... 253

IX.4.5. Catálogo Colección Vicuña Mackenna _........... 253

X. APENDICE 255

X.1. Índice onomástico _............................................. 255 



\section{INTRODUCCIÓN}

\section{I.1. Justificación del tema}

\section{I.1.1. Antecedentes y estado actual del tema}

Son cuatro las razones principales que otorgan sentido a la idea de realizar esta investigación: la inexistencia de investigaciones sobre la materia; la importancia de conocer y comprender el clima político y social que rodeó la creación de cursos de artes plásticas en Chile; la importancia (impacto o efecto posterior) que tuvieron las primeras iniciativas de enseñanza del dibujo; y la existencia de mitos y errores históricos acerca del dibujo y las Bellas Artes en Chile.

I.1.1.a. Inexistencia de investigaciones sobre la materia

Hay en Chile escasez de trabajos similares que indaguen en la formación artística con énfasis en el dibujo, en las etapas pre republicanas. Este vacío fomenta la circulación de inexactitudes históricas y teóricas en relación al tema. En las etapas previas al desarrollo de este trabajo, se comprobó la inexistencia de un análisis sobre las causas y consecuencias de los primeros cursos de arte y en particular de dibujo. Veamos el detalle de esta aseveración.

En el ámbito de los asuntos culturales, el estudio del período colonial chileno es pobre. Durante años, los historiadores han 
centrado su interés en el período republicano y sólo en los últimos años podemos constatar un aumento manifiesto de interés por investigar el período del siglo XVIII y anteriores. Sólo en los últimos 4 años se ha registrado un número mayor de investigaciones sobre música, tradición oral e historia, con recursos del fondo estatal de apoyo a las investigaciones científicas FONDECYT $^{1}$ y hemos conocido los correspondientes resultados en publicaciones recientes.

Las causas pueden ser varias y la dificultad en el hallazgo, tanto de los depósitos documentales, como de los documentos mismos es posiblemente una de ellas, ya que son numerosas las pérdidas que registran las instituciones sobre sus fondos documentales. A esto debemos sumarle la gran cantidad de documentos que se encuentran en manos privadas (colecciones particulares).

En la investigación preliminar para configurar el estado del arte e iniciar el diseño de la presente investigación, se comprobó de manera dramática la carencia de documentos sobre Bellas Artes; más aun, particularmente débil es el material documental referido al dibujo en Chile en los

1 FONDECYT es el fondo estatal para investigaciones científicas y tecnológicas administrado por la Comisión Nacional de Investigación Científica y Tecnológica (CONICYT). De este organismo depende la promoción, fortalecimiento y difusión de la investigación científica y tecnológica en el país. 
siglos XVII y XVIII. En efecto, en la investigación preliminar se detectaron sólo 906 documentos sobre dibujo ${ }^{2}$ en los 11 sistemas de biblioteca consultados en las ciudades de Santiago, Valparaíso y Concepción ${ }^{3}$. El número de documentos encontrados, divididos en categorías, se detalla en la siguiente tabla, en la cual las bibliotecas se agruparon por sistema: de una parte el sistema universitario y de otra el sistema estatal de la DIBAM ${ }^{4}$ en un mismo grupo con las bibliotecas independientes:

2 Considerando las diversas categorías de dibujo que se describen más adelante, en la sección I.6.2. 3 Se trata de ciudades que alojan a las universidades más antiguas, complejas (que realizan investigación) y que desarrollan actividades en el ámbito de las Bellas Artes.

4 DIBAM es la sigla de la Dirección de Bibliotecas, Archivos y Museos de Chile, institución pública dependiente del Ministerio de Educación. 


\begin{tabular}{|l|c|c|c|}
\hline $\begin{array}{c}\text { Categorías } \\
\text { de } \\
\text { Documentos }\end{array}$ & $\begin{array}{c}\text { Sistema } \\
\text { Universitario }\end{array}$ & $\begin{array}{c}\text { Sistemas } \\
\text { DIBAM y } \\
\text { Bibliotecas } \\
\text { Independientes }\end{array}$ & TOTAL \\
\hline Tesis & 87 & 4 & 91 \\
\hline Libros & 70 & 111 & 181 \\
\hline Catálogos & 56 & 91 & 147 \\
\hline Atlas & 6 & -- & 6 \\
\hline Artículos & 1 & 21 & 22 \\
\hline Folletos & 6 & 8 & 14 \\
\hline Fotos & -- & 39 & 39 \\
\hline Revistas & 12 & -- & 12 \\
\hline Dibujos & -- & 112 & 112 \\
\hline Mapas & -- & 36 & 36 \\
\hline Afiches & 1 & -- & 1 \\
\hline $\begin{array}{l}\text { Apuntes, } \\
\text { Cartas, } \\
\text { Informes }\end{array}$ & -- & 245 & 967 \\
\hline TOTAL & & & \\
\hline
\end{tabular}

Vale la pena repetirlo: en total se realizaron 906 hallazgos específicos sobre dibujo, desde la época colonial hasta el presente, en el total de colecciones consultadas. 
El análisis de la información encontrada nos lleva a concluir que el mayor fondo de documentos históricos en relación al dibujo ${ }^{5}$ y su enseñanza (que incluye informes, cartas, apuntes manuscritos, bocetos, registros $\mathrm{y}$ actas) se encuentra en el Archivo Nacional de Santiago de Chile. Del total de ese fondo documental, no más del $10 \%$ se refiere al período acotado en esta investigación.

Por otra parte, cabe señalar que el mayor número de libros sobre Bellas Artes se encuentra en la Biblioteca Nacional de Santiago de Chile, mientras que el mayor número de catálogos sobre dibujo se encuentra en la Biblioteca del Museo Nacional de Bellas Artes de Santiago de Chile. Se puede observar además que la mayor cantidad de tesis, memorias o seminarios sobre dibujo se encuentra en el sistema universitario; al interior de éste, en la Pontificia Universidad Católica de Chile, institución que posee además la mayor variedad de documentos sobre la materia (fotos, atlas, folletos, revistas, entre otros); llama la atención que en el sistema de bibliotecas universitario no existe ningún archivo de documentos históricos originales de gran valor que se pueda relacionar con el dibujo. Es destacable la colección Fondo Varios del Archivo Nacional en Santiago de Chile, que posee la más grande variedad de

5 Dibujo en general y dibujo artístico en particular. ver más adelante las definiciones instrumentales de estos conceptos que se emplearán en esta investigación. 
cartas, folletos, informes, legajos, expedientes y otros documentos acerca de la enseñanza de las Bellas Artes y del dibujo en particular.

Todos los documentos que se incorporan a este estudio fueron hallados en búsquedas bibliográficas efectuadas en los mismos lugares (in situ), salvo en el caso de la Universidad de Concepción, que posee un excelente catálogo en línea, abierto a consultas de terceros ${ }^{6}$. Cabe señalar que, en total, no más del $20 \%$ de los documentos están referidos al periodo colonial chileno, siendo el resto de los documentos referidos al periodo republicano.

Me aventuro a plantear otra posible causa de la ausencia de investigaciones sobre la materia. Se trata del interés político que observamos en los últimos años por consolidar una ${ }^{7}$ historia del Chile republicano. Luego de 17 años de dictadura, Chile ha debido recomenzar el tratamiento de materias antes consideradas conflictivas para el país. Al contrario de lo que sucedió

6 Para esta investigación se ejecutó un trabajo de revisión bibliográfica profunda, en las siguientes colecciones:

a. Sistema documental del Archivo Nacional

b. Sistema documental de la Biblioteca Nacional

c. Sistema de biblioteca de la Pontificia Universidad Católica de Chile

d. Sistema de biblioteca de la Universidad de Chile

$7 \mathrm{Al}$ decir "una" historia, me refiero concretamente a sostener un acuerdo sobre las versiones de los hechos en el período republicano. 
con las ciencias duras, el arte y las humanidades vieron detener el ritmo de las investigaciones y únicamente en los últimos 18 años (a partir de 1990) se ha logrado ampliar el marco de las investigaciones, no sólo en sus temas, sino además en los períodos históricos en los cuales es preciso buscar causas y razones. Sólo en los últimos 18 años hemos percibido la existencia real de un espacio para el cuestionamiento de algunos hechos que hacia las décadas de los 70' y 80' eran verdades absolutas. De esta manera, se han podido realizar investigaciones diversas que han abierto espacios para nuevas lecturas de nuestra historia y nuevas interpretaciones sobre causas políticas y efectos posteriores de hechos acaecidos hacia la segunda mitad del siglo XVIII y primera mitad del siglo siguiente. En otras palabras, la historia chilena no miró con detención hacia la colonia en el siglo XX.

A lo anterior se suma la proximidad con el bicentenario de nuestra independencia (2010), que ha hecho que comiencen a desarrollarse y difundirse investigaciones, artículos, ensayos y libros sobre cultura y sociedad, historia nacional, literatura, artes y antropología de autores tales como Villalobos, Salazar, Sagredo, Gazmuri, Salinas, Muñoz Correa, Millar, Retamal, Bengoa, Goicovic, y tantos otros, que permiten asegurar la continuidad de un análisis y pensamiento crítico, para enfrentar 
los vacíos de nuestra historia, sobre los hechos ocurridos en los siglos XVII y XVIII.

Finalmente en esta investigación, también se consultaron catálogos en línea, específicamente del sistema de biblioteca de la Universidad Nacional de San Marcos en Lima (http://sisbib.unmsm.edu.pe/); el catálogo en línea BN-Opale Plus de la Bibliothèque National de France (http://www.bnf.fr/), el Portal de Archivos Españoles (http://pares.mcu.es/) y el sitio Memoria Chilena

(http://www.memoriachilena.cl/), dependiente de la Dirección de Bibliotecas, Archivos y Museos de Chile. Todos los sitios señalados fueron consultados entre marzo de 2006 y diciembre de 2007.

El resultado de todo lo señalado, me permite aseverar entonces que en todos los hallazgos no existen vestigios de una investigación acerca de la enseñanza del dibujo en Chile en el período marcado en esta Tesis.

I.1.1.b. Importancia de conocer y comprender el clima político y social que rodeó la formación de cursos de artes plásticas

Es necesario comprender el ambiente político y social de Chile hacia fines del siglo XVIII, específicamente el marco cultural y educativo, para contextualizar los procesos de formación de escuelas y 
academias $^{8}$ ligadas a las artes plásticas, que permitan además comprender el salto cualitativo que supone crear en esta zona de Sudamérica -aún colonial- un curso de dibujo. Corresponde, para efectos de esta investigación ordenar los hechos, por una parte, y determinar la forma en que éstos impactaron en el proceso de construcción de una política de educación y cómo, en relación a ésta, se comenzó a desarrollar la inquietud por la creación de un curso de dibujo.

I.1.1.c. Importancia (impacto o efecto posterior) de las primeras iniciativas de enseñanza del dibujo

Partiendo del hecho de que Chile fue colonia de España, esta investigación pretende sentar las bases para el estudio de las influencias que las acciones emprendidas en Chile hacia fines del siglo XVIII y hasta la mitad del

8 Debo establecer una distinción nocional básica: por "academia" me referiré en esta investigación al mecanismo de enseñanza elemental libre, generalmente no reglado, que operó en forma paralela a la educación de primeras letras desde fines del siglo XVIII hasta mediados del XIX. Se trata de un mecanismo alternativo a las escuelas. Este concepto de academia, entonces, se diferencia de la academia europea, entendida ésta como un organismo cultural más complejo, que reunía a especialistas en una materia, más allá de la práctica docente. De esta forma, la Academia de Bellas Artes, que aún existe en Chile, no ejerce la docencia, sino que se constituye más bien en un cuerpo colegiado y especializado de reconocimiento intelectual y social sobre una materia. Existen además en Chile, entre otras, la Academia de Ciencias, la Academia de la Lengua, la Academia de Historia. 
$\mathrm{XIX}^{9}$ generaron posteriormente en el área de las Bellas Artes, en particular el dibujo. Esto permitirá a la actual estructura de enseñanza del dibujo artístico conocer su origen y las primeras influencias teóricas que recibió. Las fechas, si bien se explican en el punto siguiente -Delimitación del temacorresponden a la primera carta que un chileno envió a la corona solicitando se autorizara la apertura del primer curso de dibujo en Chile, al interior de una nueva noción de enseñanza reglada: la Academia de San Luis (1 de diciembre de 1795). Como límite de esta investigación he establecido el año 1858 , fecha en que se da nacimiento a la Sección de Bellas Artes.

I.1.1.d. Existencia de mitos y errores históricos acerca del dibujo y las Bellas Artes en Chile

A medida que avanza la complejidad de los espacios de instrucción en artes, se comienza a generar en Chile la idea de que las Bellas Artes y su enseñanza tienen un inicio con la fundación de la Academia de Pintura. Como explicaré en el desarrollo de esta investigación, esto recién ocurre 60 años después de la creación de los principales colegios y academias donde el dibujo primero y la pintura después, se constituyeron en las bases de la enseñanza artística en Chile. Particularmente, en dibujo

9 Las fechas mencionadas se explican en el punto siguiente, referido a la delimitación del tema en sus aspectos geográficos y temporales. 
de Bellas Artes se hace necesario esclarecer los orígenes de tales formas de enseñanza, con el propósito de evitar la generación de mitos fundacionales. Este estudio da cuenta precisamente de esos 60 años de gestiones que conducen a la enseñanza de las Bellas Artes y apunta a llenar un vacío de información y conocimiento de aspectos claves referidos al arte, la educación y la cultura en Chile. 
I.1.2. Esquema de las razones que justifican esta investigación

Investigación sobre los orígenes de la enseñanza del dibujo artístico en Chile

\begin{tabular}{|l|}
\hline 1. \\
Ausencia de \\
investigaciones sobre \\
el dibujo en el \\
período colonial \\
chileno: \\
a) Falta de material \\
documental. \\
b) Interés político en \\
construir una historia \\
del Chile \\
republicano, antes \\
que el colonial.
\end{tabular}

\begin{tabular}{|l|}
\hline 2. \\
Importancia de \\
conocer y \\
comprender el \\
contexto cultural y \\
educativo que rodeó \\
la formación de los \\
primeros cursos de \\
dibujo en Chile \\
\end{tabular}

3.
Importancia de las
primeras iniciativas
de enseñanza del
dibujo, para una
cabal comprensión
del fenómeno total y
actual.

4.

Existencia de mitos fundacionales $y$ errores históricos acerca de los orígenes y desarrollo de las Bellas Artes en Chile, en general y del dibujo en particular. 


\section{I.2. Delimitación del tema}

\section{I.2.1. Delimitación de contenido}

En este trabajo se pretende estudiar las circunstancias políticas, sociales e ideológicas ${ }^{10}$ en particular, en que se desarrollaron las ideas que incubaron los primeros cursos formales de arte en Chile, en particular de dibujo.

Las circunstancias políticas están referidas a la forma en que la organización del poder facilita o entorpece el desarrollo cultural y en particular del área artística. Las circunstancias sociales e ideológicas, nos permiten aclarar el tipo de idea que influencia al poder, lo que incluye la orientación económica imperante en el período estudiado, y la orientación estética reglada según las pautas dominantes en ese período.

Por último, será de nuestro interés en este trabajo, el estudio de las formas de enseñanza del dibujo en general y las aproximaciones de estas formas al dibujo artístico en particular en todos sus asentamientos educativos formales, es decir, colegios, academias y otras instituciones.

$10 \mathrm{He}$ decidido desglosar los aspectos que conforman la definición de cultura, para abordar

aquellos que resultan más pertinentes a esta investigación, excluyendo otros componentes, como los hábitos, el lenguaje y el patrimonio inmaterial. 


\section{I.2.2. Localización espacio-temporal}

Interesa iniciar este trabajo tomando como sitio y fecha de partida, la ciudad de Santiago de Chile en 1 de diciembre de 1795 que, como ya se dijo, corresponde a la fecha de envío de la primera carta que un chileno dirige a la corona solicitando se autorice la apertura del primer curso de dibujo en Chile. Posteriormente, otra fecha clave de esta investigación -que se ha señalado expresamente en el título de esta Tesis- es el 6 de marzo del año 1797 cuando es fundada oficialmente por Manuel de Salas ${ }^{11}$ la Academia de San Luis.

Ya señalé antes que como límite de este estudio he establecido el año 1858, fecha en que se da nacimiento a la Sección de Bellas Artes, que en la práctica constituye la primera Academia de Bellas Artes, pues reúne a las disciplinas de escultura y pintura; la iniciativa se denominará después Escuela de Bellas Artes (1891). La Sección de Bellas Artes reemplaza a los cursos de pintura de la Academia de Pintura, creada por el Presidente Manuel Bulnes Prieto, en el decreto del 4 de enero de 1849. Cabe señalar que el 17 de noviembre de 1850 se crea el curso de Arquitectura en Chile.

11 Parte importante de esta investigación se centra en la figura de Manuel de Salas C., razón por la cual he incluido un capítulo exclusivamente dedicado a esta figura. 


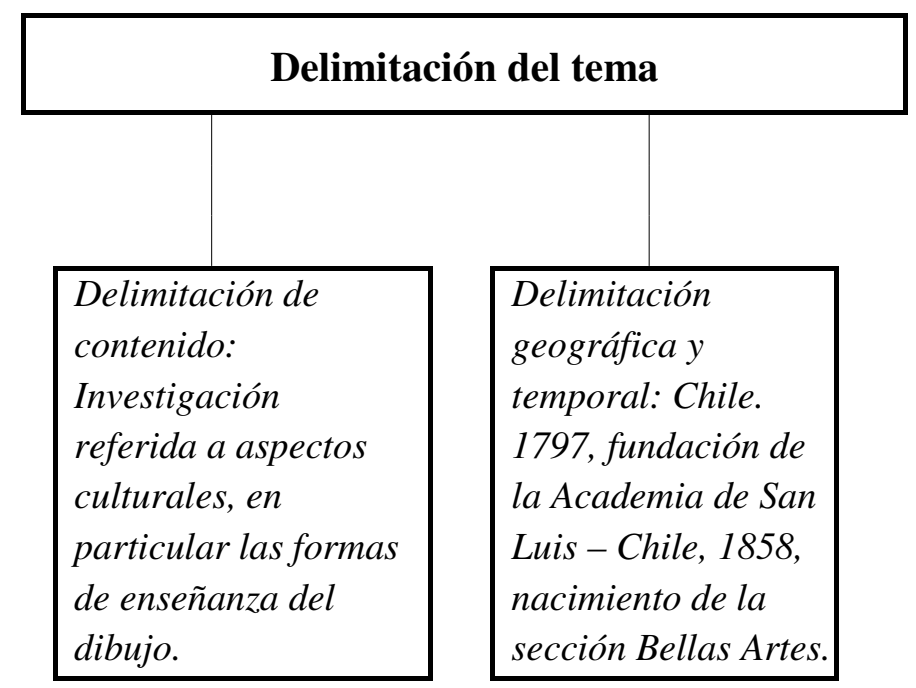

\section{I.3. Objetivos de la investigación}

Son seis los objetivos centrales que orientan esta investigación:

I.3.1. Reseñar la documentación pertinente que permita explicar las causas de la creación de los primeros cursos de dibujo en Chile; esta reseña abarca textos legales, discursos, noticias periodísticas y (o) cartas.

I.3.2. Discriminar entre las teorías, a las principales que incidieron en la creación de cursos incorporados a un sistema de enseñanza artística.

I.3.3. Comprender y exponer las principales directrices políticas y sociales del Chile de 1800 que permitieron la puesta en marcha de los cursos de dibujo, para corregir imprecisiones históricas en torno a la creación 
de las primeras iniciativas en el ámbito de las Bellas Artes en Chile.

I.3.4 Conocer los principales efectos que tuvo para Chile la creación de los cursos de dibujo artístico.

I.3.5. Determinar los hitos más relevantes en la constitución (fundación) de las primeras escuelas con cursos de dibujo en Chile.

I.3.6. Reseñar biográficamente a los principales promotores o gestores de las iniciativas de enseñanza artística, en particular a Manuel de Salas, para comprender la orientación de sus acciones en este ámbito.

\section{I.4. Hipótesis, metodología y plan de trabajo}

Esta investigación parte de la hipótesis de que el primer curso de dibujo en Chile nace a fines del siglo XVIII, de una iniciativa personal, alejada de toda directriz gubernamental. Este hecho está marcado por una parte, por la gestión de una sola persona, que recibe influencias directas de la Ilustración y en un momento político favorable, y por otra parte, por teorías y metodologías nacidas y aplicadas en España en el siglo XVIII. En esta hipótesis es necesario incluir la idea de que hubo mucho de causalidad en el impulso de esta iniciativa.

El método será básicamente de carácter cualitativo, a partir del estudio de documentos y análisis de contenido con detención en sus aspectos históricos, sintácticos y semánticos, acerca del tema principal en el marco temporal al que nos referimos. El estudio de estos aspectos parecen fundamentales, dado el lapso de tiempo que media entre los documentos que interesan y la fecha de realización de la presente investigación: 211 años. Por 
esta razón he ejecutado además, muchos análisis del tipo relacional, en donde es necesario vincular hechos con acciones y éstas con personas.

Tal como se ha señalado en páginas anteriores, en este trabajo se pretende estudiar las circunstancias políticas, sociales e ideológicas -es decir los aspectos concomitantes asociados al momento cultural- que favorecieron el desarrollo de ideas que condujeron a la creación de los primeros cursos formales de dibujo artístico en Chile. Tal como ya señalé, los aspectos políticos están referidos a la forma en que la organización del poder, en un período tremendamente convulsionado por los sucesos que ocurrían en Europa, facilitó o dificultó el desarrollo cultural en general y específicamente en el área de las Bellas Artes y el dibujo en particular.

Pese a que no se trata exactamente de una investigación histórica, abordé las circunstancias sociales e ideológicas, pues nos permiten comprender el tipo de idea que ejerció influencia en los gobiernos (el poder) y la tensión existente entre los grupos que pretendían sostener el control del territorio. En este aspecto es relevante señalar -aunque sea someramente- la importancia de comprender la orientación económica imperante en el período estudiado y la orientación estética, reglada según las pautas dominantes en el período histórico que interesa.

En esta investigación se abordará, además, la forma en que los diversos asentamientos educativos formales, es decir, colegios, academias y otras instituciones, fueron capaces de asumir la enseñanza del dibujo, que como veremos no tiene ni los rasgos ni la envergadura que conocemos hoy.

Indicado ya en detalle el período histórico que comprende esta investigación, cabe señalar que metodológicamente es preciso indicar los factores de particular relevancia presentes en ese 
período, que permiten establecer conclusiones sobre sus efectos en el siglo siguiente, a saber: fin de la colonia; inicio de un movimiento político mundial; cambio en la estructura de las ideas y finalmente el nacimiento de una capa de intelectuales chilenos tales como Francisco de la Lastra, Juan Egaña, José Antonio Rojas, Manuel de Salas, Manuel Blanco Encalada ${ }^{12}$, entre otros, quienes no obstante ser funcionarios del sistema colonial, jugarán un rol destacado en la construcción de la República.

Del análisis detallado de documentos de época capturados en $\operatorname{archivos} \mathrm{y}$ bibliotecas y de la literatura generada por especialistas en historia de Chile y en historia del arte, pretendo establecer vinculaciones o asociaciones cruzadas de ideas, fechas y acontecimientos (método relacional del análisis de contenido) que puedan arrojar conclusiones fundamentadas para satisfacer los objetivos de esta investigación.

Particularmente, mediante el sistema de cruces de ideas, vinculaciones de hechos e interpretación de datos históricos, pretendo probar que hubo mucho de casualidad en la creación del primer curso de dibujo en Chile. Para que ello ocurriera debieron reunirse un protagonista con un pensamiento que favorecía la transversalidad y que recoge las ideas de la Ilustración; condiciones políticas y económicas precisas y favorables a la implantación de una noción de educación popular; y finalmente, un reordenamiento político y administrativo en Europa que golpea con sus efectos a las colonias de ultramar.

12 Estos nombres aparecerán recurrentemente a lo largo de esta investigación. 


\section{I.5. Plan inicial del tratamiento de la cuestión}

Ha quedado señalado que el asunto central de esta Tesis se aloja en el período de 63 años que se inicia en 1795 y se extiende hasta 1858. El año 1795 marca el momento en que se realizan los primeros esfuerzos por lograr la aprobación por parte del Rey de España a la creación de una academia de estudios chilena, que incorpora en sus planes la enseñanza de la aritmética, el dibujo y la geometría. Finaliza el estudio hacia 1858, momento en que ya en plena República se formaliza la constitución de versiones rudimentarias de escuelas de Bellas Artes y de Arquitectura.

El plan entonces abarca los tópicos que se desarrollarán sistemáticamente mediante las siguientes vinculaciones o cruces, tanto verticales como horizontales. Veamos el esquema que los señala: 
Esquema del plan inicial

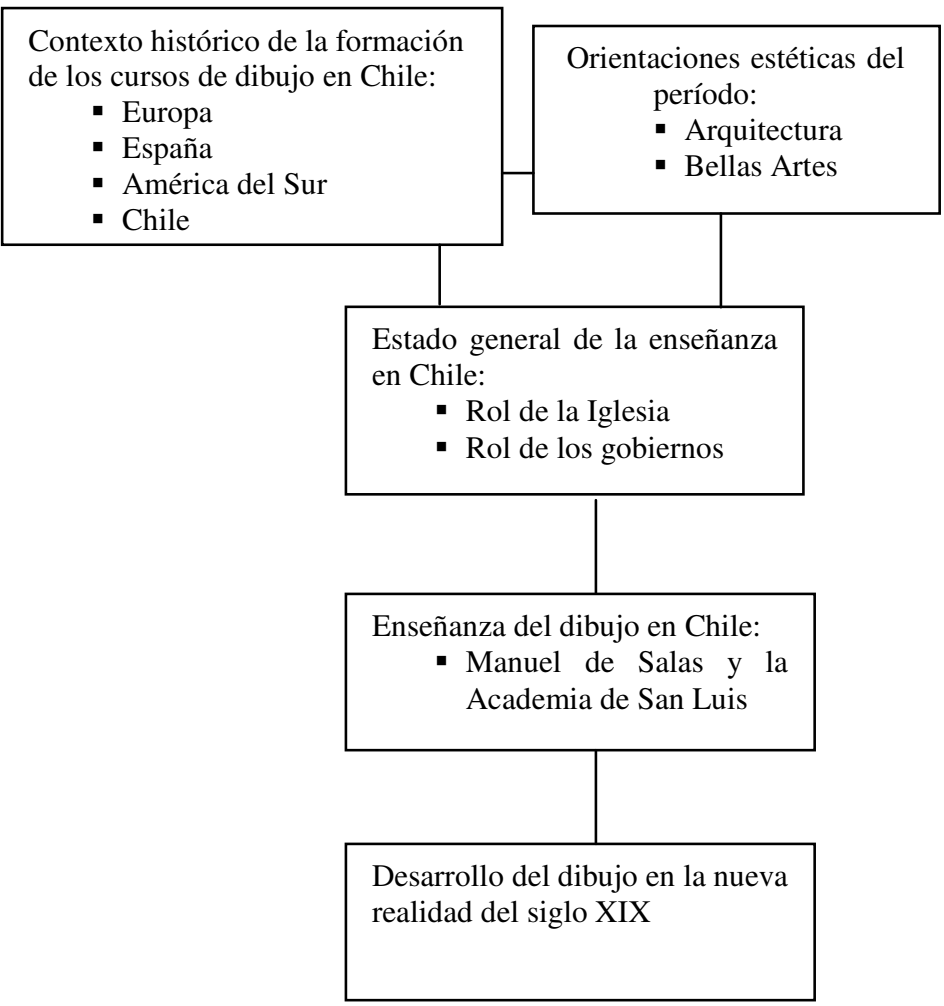

\section{I.6. Delimitación conceptual de las materias abordadas}

Dos conceptos resultan fundamentales para esta investigación y deberán ser explicados y acotados teóricamente aquí, pues ayudarán a comprender los límites de este trabajo: se trata de los conceptos de enseñanza y de dibujo. Me ha parecido relevante y pertinente conjugar planteamientos más contemporáneos en torno a la noción de enseñanza, contextualizada en los años en que esta investigación se centra. De esta forma, el lector podrá aproximarse aquí a nociones contemporáneas que generan la 
comprensión ampliada de la misma noción contextualizada al siglo XVIII.

\section{I.6.1. Enseñanza}

Emplear la denominación enseñanza o educación artística resulta desmedidamente exigente si pensamos aplicarla al período que abarca esta investigación. Sabemos hoy que dicho concepto es complejo, pero también sabemos que es un término bastante preciso. Comparto la sencilla explicación que da Rudolf Arnheim acerca de las tres áreas centrales de aprendizaje a las que colabora la educación artística en la labor de formar una persona plenamente desarrollada. Dice Arnheim:

"La primera de estas áreas centrales es la filosofía que instruye al alumno en a) lógica, es decir la capacidad de razonar correctamente, b) la epistemología, es decir la capacidad de comprender la relación de la mente humana con el mundo de la realidad, y c) la ética, es decir, conocer la diferencia entre lo correcto y lo incorrecto. La segunda área es el aprendizaje visual, donde el alumno aprende a manejar los fenómenos visuales como medio principal para abordar la organización del pensamiento. La tercera área es el aprendizaje lingüístico, capacitar al alumno para comunicar verbalmente los frutos del pensamiento." 13

13 Cfr. Arnheim, Rudolf en Consideraciones sobre la Educación Artística. Barcelona, Paidós estética. Primera edición 1993, p 89. 
Entendemos pues estas tres áreas como parte de un proceso mayor. Educación -y más específicamente educación artística- como una noción más compleja, no está refrendada documentalmente en Chile, en sus límites conceptuales, en el siglo XVII ni en el XVIII. Declaraciones que se dirigen a acotarla no se registrarían sino hasta mediados del siglo siguiente, concretamente cuando en 1836, se lanzan las primeras bases de lo que sería luego, en 1842, la Escuela Normal de Preceptores (Andrés Bello ${ }^{14}$ ). Es decir, en el período que nos interesa, no existe una declaración en el país que entienda el proceso de enseñanza aprendizaje como un procedimiento estructurado, aplicable a los sistemas de educación reglada. No obstante, a medida que avancemos en las formas de pensamiento de algunos iniciadores de los procesos de enseñanza artística en Chile, veremos que algunas de estas ideas centrales enunciadas por Arnheim, estaban presentes entonces, aunque de forma precaria.

En Chile, y en general en el Virreinato del Perú, la educación se entendía únicamente como la enseñanza de materias concretas, destinadas a la adquisición por parte del estudiante de habilidades o destrezas, cuando no de conocimientos generales (enseñanza de primeras letras), básicos. En otras palabras, la noción de educación o más bien dicho el proceso de enseñanza

14 Andrés Bello (Caracas, 1781-Santiago de Chile, 1865): personaje destacado en el panorama de la cultura chilena. Colaborador de Simón Bolívar, se establece definitivamente en Chile en 1829 y comienza a ejecutar importantes acciones en beneficio de la cultura y la educación superior. Realizó aportes como redactor en diversos medios de prensa. Fue profesor y jurista. Relevante fue su participación en la formación de la Universidad de Chile y en el proyecto de creación de la Escuela Nacional de Preceptores (profesores de primeras letras) en el siglo XIX. 
aprendizaje se centró durante muchos años en un solo aspecto del proceso, el acto de "entregar" y no en la metodología a emplear para que los que reciben, aprendan.

Según la destacada educadora chilena Amanda Labarca $^{15}$, los propósitos fundamentales para la implantación de este modelo de educación fueron por una parte el sometimiento y por otra el adoctrinamiento (1939). Esta explicación se basa en la noción de que para los conquistadores, la enseñanza era una forma de sometimiento de los indígenas, en tanto que el aprendizaje de la lengua española, facilitaba el trabajo esclavo. Por otra parte, el adoctrinamiento era la razón principal que justificaba la presencia de religiosos católicos en estas tierras y otorgaba respaldo ideológico a las incursiones ofensivas sobre territorios indígenas, justificando incluso las masacres. Según Labarca, la enseñanza de indígenas a base de los Colegios de Naturales dependientes de los jesuitas fue un fracaso por el escuálido número de estudiantes, y lo siguió siendo luego a manos de sus sucesores, los franciscanos. La razón, según esta autora, radica en que durante años se confundió enseñanza con adoctrinamiento, en una forma en que la construcción de una cultura equivalía a sobreposición cultural. En ese momento del proceso de colonización, las instituciones, las ideas y los

15 Amanda Labarca (1886-1975) tuvo un rol relevante en el fortalecimiento y renovación de la educación en Chile. Autora de muchos artículos, investigaciones y libros sobre su especialidad, su Historia de la enseñanza en Chile (Imprenta Universitaria. 1939, 364 páginas) fue el documento más completo sobre el tema, que circuló en la primera mitad del siglo XX. Para profundizar en la idea aquí enunciada, se pueden revisar en el texto aludido, los capítulos 1 y 2. 
productos materiales ${ }^{16}$, debían servir al propósito de los dominadores.

Estas causas, sistemas y efectos se mantuvieron en el tiempo, sólo que llegado un momento del siglo XVIII, cuando el grupo receptor (los indígenas o naturales) comenzó a ser sometido a un plan de pacificación que duraría 100 años, como parte final de la Guerra de Arauco $^{17}$, el proceso de educación (enseñanza) comenzó a paralizarse, segmentándose la población de estudiantes: el conocimiento comenzó a ser privilegio de una sola clase social. No obstante, hacia fines del siglo XVIII esta idea volvió a cambiar a propósito de suponerse que para un mayor desarrollo productivo de la industria, por muy precaria que ésta fuera en ese momento, era necesario capacitar o perfeccionar la mano de obra. ${ }^{18}$

Las diferencias fundamentales entre los distintos tipos de educación radicaban en la dependencia administrativa: Iglesia o Estado. Adicionalmente, en el

16 Según los componentes de la cultura enunciados por Chinoy. Ver Chinoy, E., La Sociedad. Fondo de Cultura Económico. México. 1966.

17 Se denomina Guerra de Arauco a la resistencia de los pueblos aborígenes a ser sometidos por los colonizadores. La Batalla de Reinohuelén en 1536, marca la fecha de inicio del conflicto entre los mapuches y el hombre blanco, españoles primero y chilenos después. El proceso conocido como Pacificación de la Araucanía concluyó en 1881, y marcó el fin del conflicto; fueron, en total, 345 años de guerra.

18 Resulta muy esclarecedor observar que las ideas de Labarca respecto a la implantación del proceso de educación en Chile, las que, aunque básicas, concuerdan con las expresadas por Gabriel Salazar en Construcción del Estado en Chile (Santiago, Editorial Sudamericana, 2005, 550 págs.), en relación a cómo el poder, hacia fines del siglo XVIII, estaba en manos de una élite intelectual y mercantil, ilustrada, lo que generaba dependencias de similar orden a las que se ejercieron en los inicios de la colonia respecto a los sujetos comprometidos en los procesos de educación en Chile. 
siglo XVII no era conocida en Chile la idea de un proceso instruccional dinámico, o la relación entre enseñanza y aprendizaje, la noción de currículo, la valoración de factores externos al aula tales como la familia o el ambiente afectivo; tampoco la noción de cultura -como la concebimos hoy- o las concomitancias socio económicas del estudiante o políticas del país o las áreas centrales de un proceso educativo que impliquen la participación de la filosofía, el lenguaje y el aprendizaje visual y, en fin, la suma de aspectos que sabemos hoy que mediatizan la efectividad de la formación de una persona desde el punto de vista cognitivo y afectivo.

Medina $^{19}$ y Labarca, que con una perspectiva histórica abordaron el estudio de la enseñanza en nuestro país, concuerdan en que la pobreza en Chile en los siglos previos a la era republicana era extrema y la educación o la vida cultural no estaban dentro de las prioridades de los colonos y colonizadores. Cabe señalar que tanto la pobreza como el desinterés de los administradores por la enseñanza, impidieron que se gestara una organización central y laica dedicada a la enseñanza. Esta situación comenzaría a cambiar con mucha lentitud, sólo hacia fines del siglo XVIII. Llama la atención la pobreza que se describe en el siguiente párrafo de un acta del Cabildo de Santiago y que ha

19 José Toribio Medina (1852-1930), bibliófilo, historiador, coleccionista e impresor chileno de gran producción historiográfica. Fue autor de importantes obras de metodología científica. Tres de sus obras fueron consultadas para esta investigación: La educación en el siglo XVIII en Chile (Santiago, Imprenta Elzeviriana. 1901); La instrucción pública en Chile desde sus orígenes hasta la Fundación de la Universidad de San Felipe (Santiago de Chile, Imprenta Elzeviriana. 1905, v.1 textos; 492 páginas) y La Real Universidad de San Felipe. Tomo I, Texto (650 pp.) y Tomo II, Documentos (373 pp.). (Santiago de Chile. Imprenta y Litografía Universo. 1928). 
sido consignada además en La Historia de la enseñanza en Chile ${ }^{20}$. Esta cita resulta ilustrativa al momento de acotar el concepto que nos interesa. La anécdota, si es que así podemos denominar al episodio, ocurrió hacia fines del siglo XVI, pero la situación de pobreza generalizada en Chile perduró hasta avanzado el siglo XIX:

"El 2 de septiembre de 1580 se presentó el susodicho Moya ${ }^{21}$ ante el Cabildo de Santiago, exponiendo que ya estaba enseñando gramática y pidiendo se le diese ayuda <porque no se puede sustentar con lo poco que gana y es muy útil y necesario en esta ciudad>, le subvencionó la corporación con $\$ 40$ anuales. Desde 1579 a 1582 se tienen noticias de su faena. Después se pierde el rastro. Los estipendios del Cabildo no alcanzaron a ser pagados; los hijos de los colonos carecían de recursos, el maestro no podía tampoco vivir sin ellos...."

La definición y límites de los conceptos de "educación” y "enseñanza”, casi siempre empleados como sinónimos, no constituyen el centro de esta investigación. No obstante, para efectos de comprender el alcance de estos términos en el asunto que nos ocupa, debo aclarar que emplearé más

20 Labarca, Op. Cit., p. 10.

21 Se refiere a Gabriel de Moya, quien junto al cura Juan Blas, fueron los primeros profesores de gramática latina o latinidad acreditados ante el Cabildo, que se registran en esa época. El latín fue la segunda lengua en Chile, hasta fines del siglo XVIII y, tal como lo señalan los documentos, fue Manuel de Salas la primera persona en Chile que decidió ofrecer clases en lengua de origen (castellano). Haré referencia extensa a Manuel de Salas en el capítulo V. 
recurrentemente el segundo -"enseñanza"- por ser un término más acotado a la acción de entregar un conocimiento específico. Esta limitación conceptual del término es muy pertinente en este estudio, dada la precaria condición en materias de educación y cultura ya señalada, del período que se estudia.

Por otra parte, las cartas, oficios y otros documentos oficiales emitidos en Chile hacia el siglo XVII, poco mencionan la palabra educación y únicamente se limitan a aplicar la denominación de maestro a quien enseña. La enseñanza sólo fue considerada una materia de preocupación para el Estado y concebida más complejamente como instrucción pública, una vez lograda la independencia de Chile y consolidada la república, cuando el proceso de reconquista española sobre sus asentamientos en las Indias había concluido sin éxito; esto es hacia 1814. Dicho lo anterior se debe destacar que hay dos chilenos que sí asumen a fines del siglo XVIII la noción más compleja de enseñanza: Manuel de Salas (ver capítulo V) y José Joaquín de Mora ${ }^{22}$. Ambos dejaron cartas y memoriales donde el tema es tratado con altura de miras y profundidad, y aportaron una visión adelantada acerca de esta actividad, sin embargo sólo el primer mencionado resulta pertinente para esta investigación.

22 José Joaquín de Mora (1783-1864). Nacido en Cádiz, llega a Chile en 1827. Redacta aquí la constitución política de 1828; un año después funda -con la ayuda del Presidente A. Pinto- el Liceo de Chile, el que posteriormente fue incorporado al Instituto Nacional. Expulsado de Chile bajo el gobierno conservador de 1831, vivió en Argentina y Bolivia, hasta volver a su patria y fallecer en Madrid. 


\section{I.6.2. Dibujo}

Entre los textos recogidos en esta investigación, fundamentalmente cartas y libros de historiadores chilenos de los siglos presente, pasado y antepasado, se puede observar una gran cantidad de términos que hacen referencia al dibujo en particular, y a las Bellas Artes en general. La literatura contemporánea especializada ha dado para las artes plásticas o Bellas Artes la denominación más amplia y por lo mismo más imprecisa de Artes Visuales. Esta imprecisión deberá ser siempre tenida en cuenta para efectos del desarrollo de esta investigación, toda vez que constantemente se deberán realizar "traducciones" o establecer equivalencias al lenguaje contemporáneo de los conceptos que se aplicaban en Chile en el siglo XVII, para el tratamiento de las materias de nuestro interés. Por lo mismo, emplearé más recurrentemente el sintema Bellas Artes, por corresponder con mayor precisión al significado actual de las manifestaciones artísticas chilenas en el período estudiado. No obstante, habrá que tener cuidado en reconocer que dicho concepto se torna borroso en la medida que nos alejamos del momento actual.

En la tarea de ser precisos, resulta particularmente pertinente a este trabajo la investigación de Gómez Molina $^{23}$ et al, en relación a los nombres del dibujo.

23 He tomado a Juan José Gómez Molina (Carcelén, 1943; Albacete, 2007) como un autor que establece mediaciones teóricas para comprender la aplicación de conceptos asociados al dibujo. Con este autor, pretendo establecer un acuerdo contemporáneo acerca de conceptos que se repetirán en esta investigación. En concreto, el libro Los Nombres del Dibujo (Madrid, 2005.

Cátedra. 576 pp. ) ha sido una fuente científicamente irreprochable para avanzar en la comprensión de términos asociados al dibujo. 
Un primer cruce que me interesa realizar dice relación con los nombres del dibujo que se asocian -al decir de Lino Cabezas ${ }^{24}$ - a formas de conocimiento y sus aplicaciones. Este autor desarrolla una taxonomía que diferencia el dibujo técnico y(o) lineal, del dibujo artístico, el primero estrechamente asociado a la noción de geometría clásica y el segundo de ejecución libre $\sin$ sometimiento "a normas obligatorias y uniformadoras". Pese a que Cabezas establece una separación entre dibujo artístico y dibujo artesanal, debemos recordar que la noción de arte, como principio epistemológico, era débil en Chile en la época que nos ocupa, por lo que la aplicación de una taxonomía más fina hacia fines del siglo XVIII era imposible. Arte y artesanía, siendo operaciones productivas distintas, tuvieron un adiestramiento común en el dibujo que, como se verá más adelante, sólo pudo separarse en Chile con la creación de la Academia de Bellas Artes y de la Escuela de Artes y Oficios en el siglo XIX

Hacia el 1750, sabemos que existía el oficio de "trazador", equivalente colonial a nuestro actual "delineante", "dibujante de arquitectura" o "dibujante de planos" $"$. El trazador, participante de los gremios de artesanos (pero que no figura en los registros de los gremios del Cabildo de Santiago antes del año mencionado), realizaba su trabajo en conjunto con los maestros albañiles y obviamente con los alarifes (maestros mayores), equivalentes a nuestros contemporáneos arquitectos. Por otra parte, podemos

24 Ibídem p. 226-283.

25 Se conoce esta actividad hoy en día también con el nombre de "delineante". 
reconocer que al oficio de trazador le podía corresponder la elaboración de planos urbanos y algunos bosquejos de fortificaciones. Hacia fines de 1700 y una vez creada la Academia de San Luis, sabemos que los trazadores y maestros de otros oficios podían acudir a la Academia a recibir instrucción para luego dar el examen y ser aceptados en el gremio de artesanos mayores. Deducimos entonces que la palabra "dibujo" era posible entenderla -en esa áreadesde el punto de vista de la representación gráfica de ideas para arquitectura y urbanismo.

La misma literatura consultada nos habla de grabados y petipie para referirse a bosquejos que, en el primer caso, no necesariamente estaban asociados a la reproducción mecánica de los dibujos $\mathrm{y}$, en el segundo, estaban asociados a pequeños croquis de ideas básicas. Ambos conceptos se emplean para referirse a dibujos con una amplitud de aplicaciones y ya no necesariamente asociados a asuntos técnicos ni a la arquitectura ${ }^{26}$.

La asociación entre las palabras dibujo y enseñanza propiamente tal, es establecida por primera vez por Manuel de Salas, para referirse al adiestramiento que recibirán en su academia los artesanos mayores en los diferentes oficios en que rinden examen. Se deduce de esto que concurren a aprender técnicas de representación gráfica fundamentalmente los trazadores, orfebres, técnicos mineros (excavadores), alarifes, mueblistas y cordoveses ${ }^{27}$. Sabemos además

26 Ibídem, p. 420. Cabezas, define Pitipie (petipie, del francés petit pied) como equivalente a un concepto de escala de medida y la relación entre la representación de un cuerpo con su real.

27 Expertos en diseño de objetos que mezclaban la talabartería y la platería. 
que al ampliarse el concepto de traza o grabado a una noción más amplia y genérica como dibujo, se posibilita el desplazamiento de ese oficio al mundo de la representación artística. Asumo esta interpretación como una parte substancial de lo que hoy identificamos con Bellas Artes, pero reconocida hacia fines del 1700 sólo por un puñado intelectuales chilenos, Manuel de Salas entre ellos.

\section{I.6.3 Tipos de dibujo para esta investigación}

Pero si pido al lector, en la lectura de este documento, hacer permanentemente "traducciones" contemporáneas al antiguo uso de este concepto ¿qué será "dibujo" entonces -como concepto contemporáneo- para esta investigación?

La palabra "dibujo" se filtra en nuestra vida cotidiana, "con un valor que parece exceder el uso de esa disciplina, para nombrar una serie de valores que pertenecen al fundamento de una actividad esencial, en el hecho mismo de nombrar y comprender las $\operatorname{cosas}{ }^{28}$ nos dice Gómez Molina. Esta amplitud, que por cierto complica una definición, no hace más que confirmar precisamente la esencia compleja, en su base, en su origen, de la disciplina del dibujo, de su acción y de sus resultados (productos) y por lo mismo se ha establecido un uso cotidiano que ha logrado internalizar esta noción en el lenguaje del arte, la educación y la cultura, con una amplitud inexistente en los siglos anteriores al XIX.

28 Las lecciones del dibujo. Gómez Molina, Juan José. Madrid, Cátedra. 1995, página 17. 
Comparto una noción amplia que abarque al dibujo tanto como acción creativa, y como acción representativa. Esta noción dual, aunque amplia, es práctica y funcional pues considera el ejercicio del dibujo y(o) su aplicación en diferentes campos. En esta dualidad, la primera zona más amplia abarca la interpretación de lo real, el posible significado concreto de lo trazado en términos de mundo simbólico y las ideas del dibujante, al margen de una realidad pura. Por otro lado, en una segunda zona a la que Otxotorena ${ }^{29}$ denomina dibujo e imitación, el dibujo está asociado a la mimesis y estrictamente a la relación entre dibujo y un modelo real o imaginario.

Entendido más en una visión epistemológica, que funcional, Gómez Molina señaló que

“...el dibujo se establece siempre como la fijación de un gesto que concreta una estructura, por lo que enlaza con todas las actividades primordiales de expresión y construcción vinculadas al conocimiento, a la descripción de las ideas, las cosas y a los fenómenos de interpretación basados en la explicación de su sentido por medio de sus configuraciones." 30

Esta definición de dibujo que comparto ampliamente es, en alguna parte, similar, cuando no

29 Tomo las ideas de Otxotorena que divide la disciplina del dibujo de manera dual, para efectos de acercarla a un análisis del dibujo como experiencia, representación y proyecto en arquitectura. Ver Otxotorena, J. Sobre Dibujo y Diseño. Pamplona, T6 ediciones. 1996, pág. 36.

30 Ibídem Gómez Molina, pág. 17. 
complementaria, a las ideas de Nauman cuando señaló: "dibujar es equivalente a pensar".

Dicho esto podemos colegir que cualquier idea acerca del dibujo que podamos tener hoy es diferente a la reducida concepción manejada en el siglo XVIII en Chile: dibujo era aquí la representación concreta en papel, mediante trazos, de explicaciones técnicas figurativas asociadas a las artesanías (objetos) y construcciones inmuebles, y bocetos para obras en otras disciplinas reconocidas como Bellas Artes. Esa noción, contenida en esta definición, abraza distintas formas de conocimiento y diversas aplicaciones. En el período que abarca esta investigación, es posible asociar incluso, la palabra dibujo a la enseñanza de la caligrafía, como manifestación "artística" incluida en formas elementales de enseñanza de la lecto-escritura. De la muy escasa producción de dibujos siglo XVIII que se guardan en los archivos y museos, y que podrían categorizarse como dibujos, abundan los planos de ciudades y pueblos, vistas en corte y elevación de algunos edificios públicos, junto con bocetos para insignias, o escenas callejeras. Es en este contexto que la palabra "dibujo", era en Chile, a fines del siglo XVIII, un concepto que sin diferenciar formas o tipos de conocimiento, era asociado a la idea de "dibujo artístico", es decir relacionado con las artes plásticas o Bellas Artes. No obstante, en el transcurso de esta investigación pude observar que a medida que transcurre el siglo XIX, el dibujo comenzó a especializarse cada vez más, independizándose de "otras disciplinas", tales como la cartografía, la arquitectura, la ilustración o el dibujo técnico. Así, podemos encontrar "dibujos artísticos" que tuvieron un valor propio, prescindiendo de una posterior 
elaboración en pintura o escultura; tal es el caso de las obras del artista alemán Mauricio Rugendas o de Claudio Gay, pintores a los que aludiré visualmente en páginas siguientes de esta investigación.

No obstante el uso amplio de la palabra dibujo empleada en el siglo XVIII en Chile, parece pertinente metodológicamente establecer un orden que permita referirse al dibujo en todas sus aplicaciones, lo que facilita ver y o distinguir su comportamiento y desarrollo. Esta taxonomía distingue los diferentes tipos de dibujos que existían en Chile en el siglo XVIII y primera mitad del XIX, según sus campos de aplicación, partiendo de la base que en dichos campos primaban las necesidades de las actividades gremiales (artesanales) y una noción de arte venida de Europa.

La revisión de las fuentes documentales permite sugerir los siguientes campos de aplicación del dibujo en Chile, que operan como variaciones de una noción (de dibujo):

Clase A. Objetos-Dibujo como obra de Bellas Artes o dibujo artístico: se incluyen dos categorías de dibujo:

Clase A, Categoría 1. Dibujos con estructura de trazos abstractos y (o) representacionales, con valor de obra final, entendidos como obra en dibujo. 


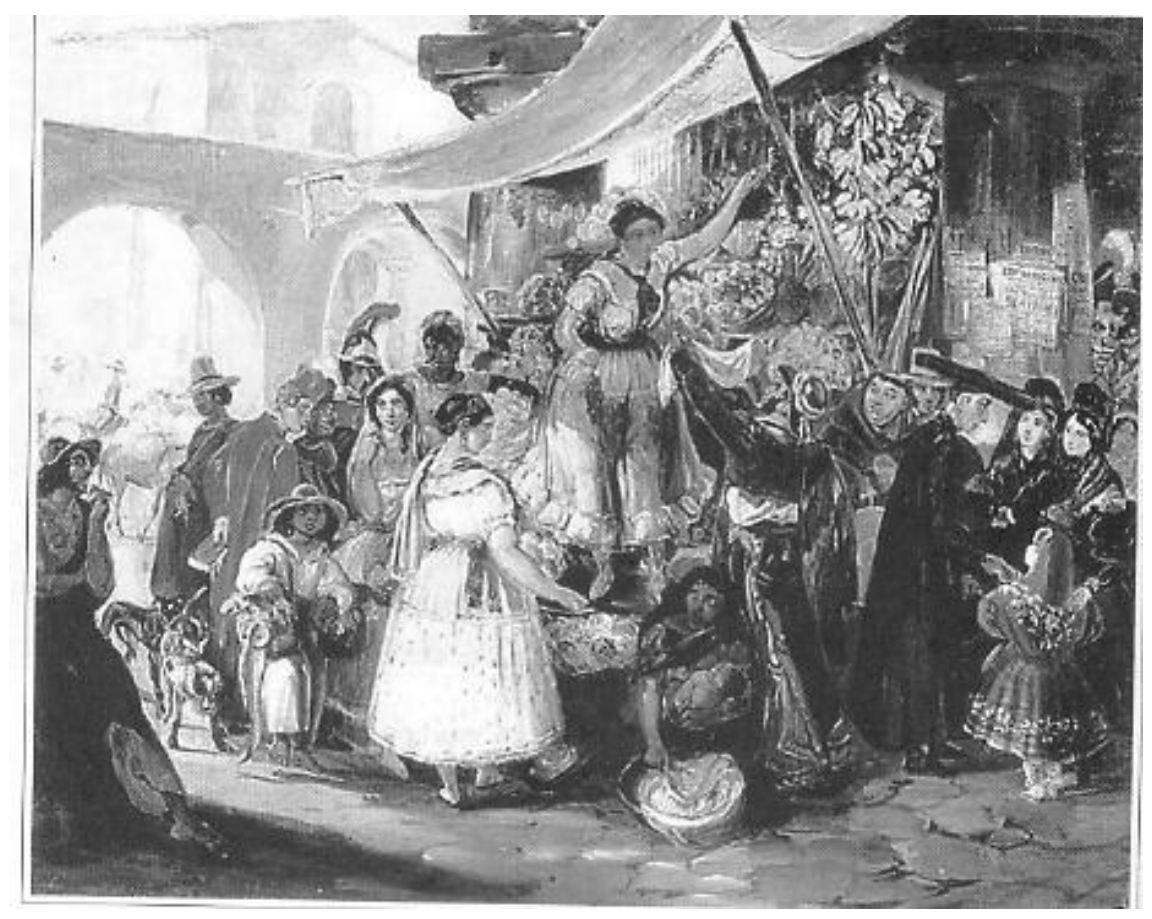

Lámina $\mathrm{N}^{\circ} 1$

Dibujo Clase A. Categoría 1. Dibujo con valor de obra final. La Reina del Mercado. México. M. Rugendas. Lápiz sobre papel. 1833. (De Rugendas, de T. Lago)

Clase A, Categoría 2. Dibujos con estructura de trazos abstractos y (o) representacionales, con valor de boceto previo, croquis o esbozo. Se incluyen también aquí los croquis sin resultado final en una obra "mayor" o definitiva. Se incluyen dibujos ejecutados para su reproducción en formato de grabado, lámina o ilustración. 


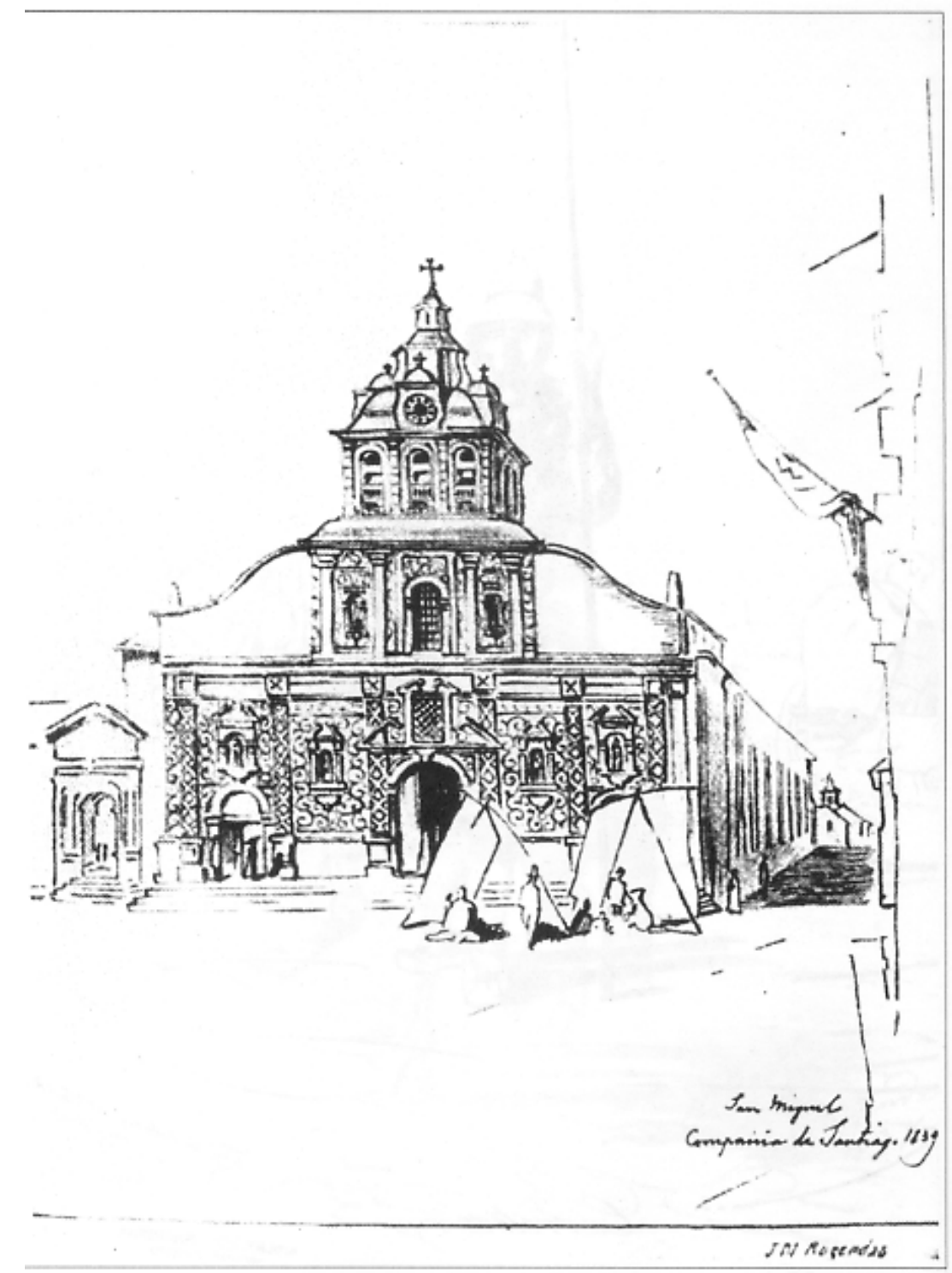

Lámina $\mathrm{N}^{\circ} 2$

Dibujo Clase A. Categoría 2. Croquis de la Iglesia de la Compañía de Santiago de Chile. M. Rugendas. Lápiz sobre papel. 1839. (De Rugendas de T. Lago) 
Clase B. Objetos-Dibujo como documento. Incluye cuatro categorías:

Clase B, Categoría 1. Dibujo Histórico: Incluye mapas con distintos grados de elaboración, croquis explicativos, diagramas de comportamiento de personas o sucesos con valor de documento histórico (esquemas de viajes, ocurrencia de matanzas, disposición de tropas en una batalla).

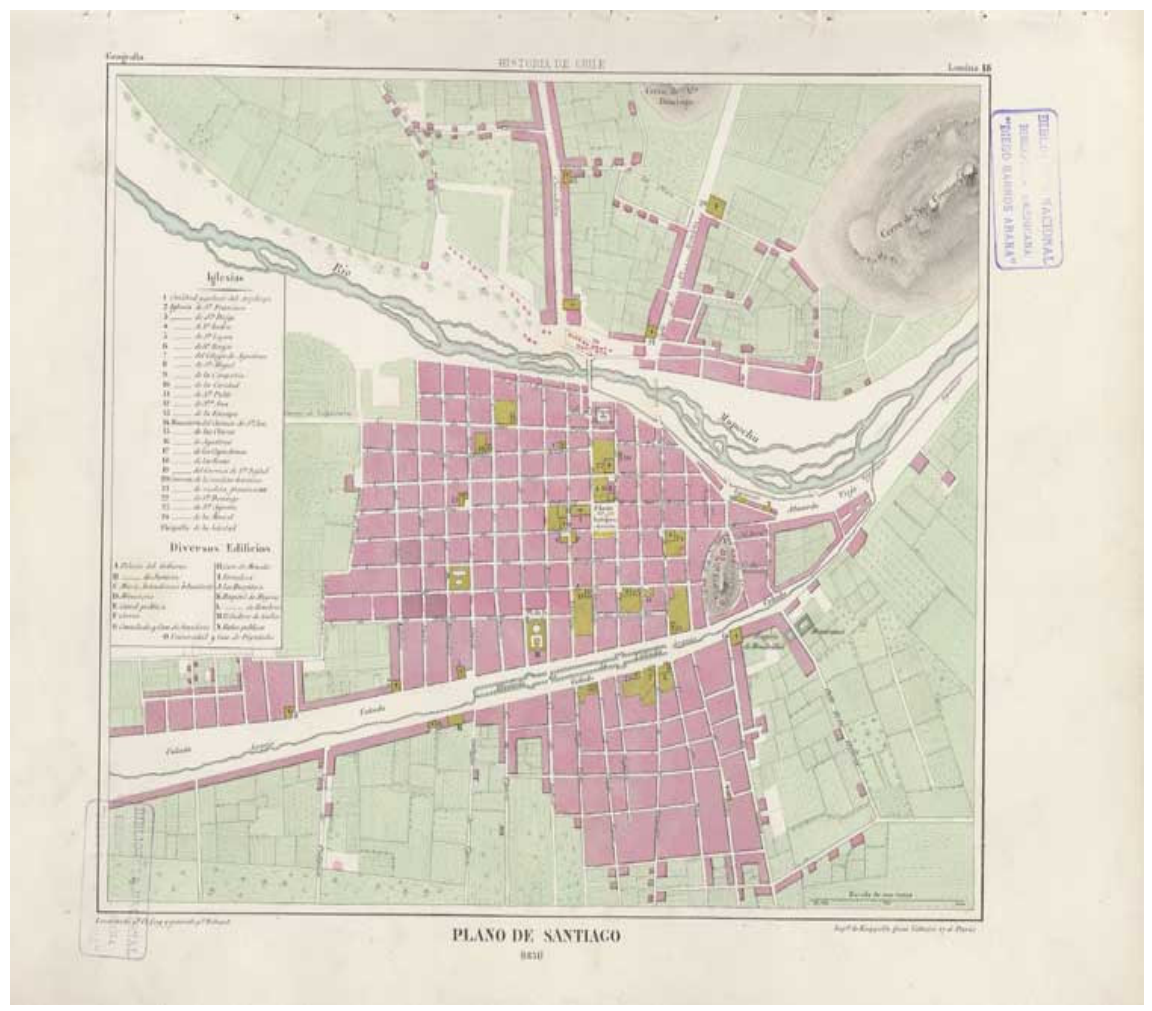

Lámina $\mathrm{N}^{\circ} 3$

Dibujo Clase B. Categoría 1. Mapa de la ciudad de Santiago de Chile, por C. Gay. 1850. (Biblioteca Nacional de Chile) 
Los principales documentos de esta categoría y que circularon antes, durante y poco después del período que nos interesa, se encuentran en carpetas de dibujos de la época y álbumes de reproducciones litográficas. $\mathrm{Al}$ respecto los principales son: el Atlas de la historia física y política de Chile. (Ed. Thunot, 1854), hoy llamado simplemente Atlas de Claudio Gay con paisajes y escenas costumbristas de Chile; y la obra de Johann Moritz Rugendas, con escenas urbanas y campesinas, con gran detalle de la vida cotidiana.

Clase B, Categoría 2. Dibujo Técnico: Incluye esquemas explicativos de funcionamiento; instrucciones de uso (de herramientas, aparatos, dispositivos, equipos e instrumentos); diagramas y descripciones de comportamiento (de compuestos químicos, físicos, de sólidos); de procesos (descripción visual de etapas, procedimientos y partes). Trascripciones de formas, volúmenes y planos según normas de proyección. Dibujo técnico aplicado. Dibujo como croquis de apoyo a la arquitectura, paisajismo y diseño.

En Chile, tanto en los archivos de las órdenes religiosas como en aquellos del Cabildo, se conservan dibujos que circulaban hacia 1600, con planos de edificaciones civiles y militares. En efecto, se guardan rudimentarios planos de ciudades elaborados hacia 1600, principalmente los de Fray Diego de Ocaña, cuyos dibujos abarcan además los incluidos en la clase B4, que explicaré más adelante. Otros del cura Alonso de Ovalle. 


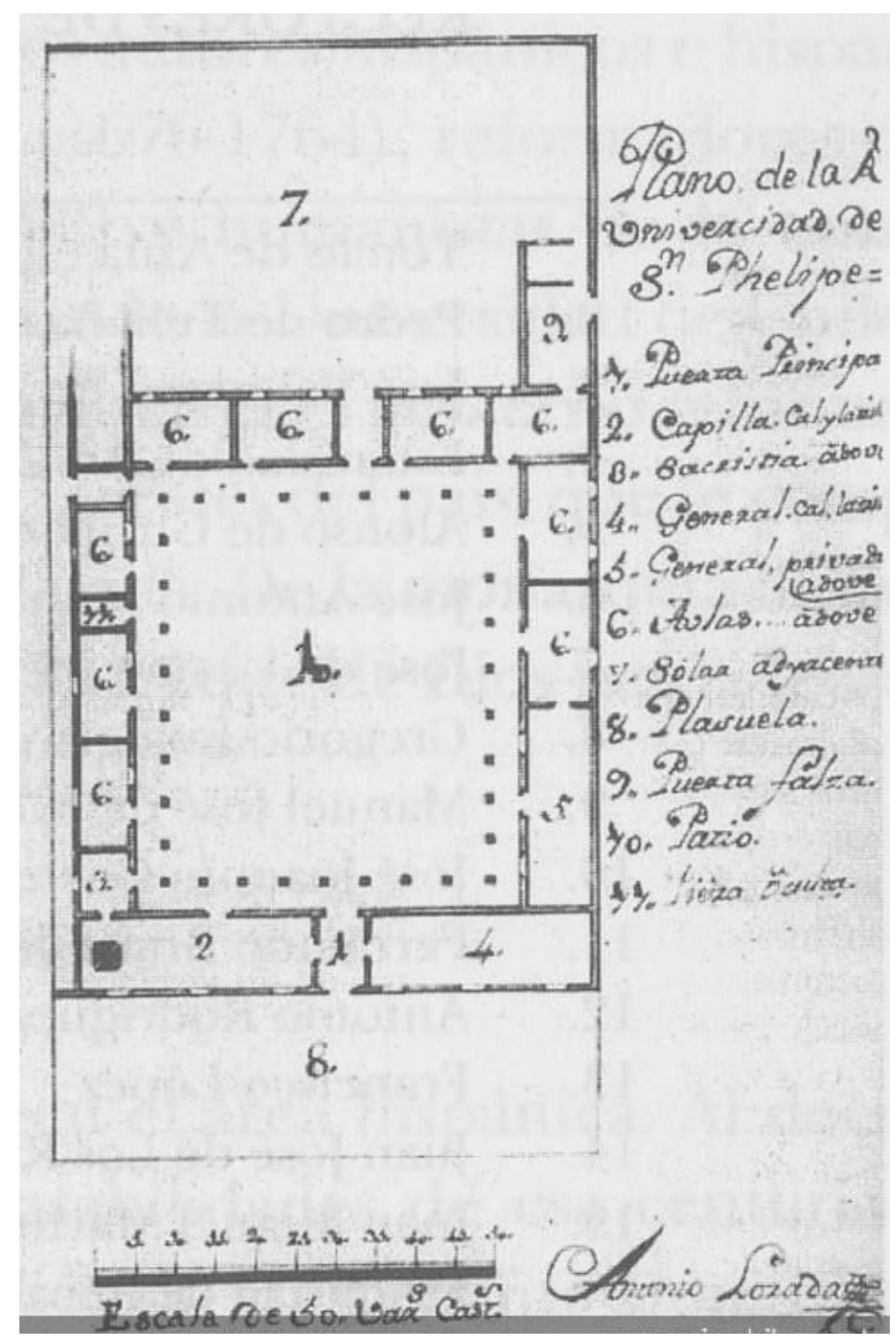

Lámina $\mathrm{N}^{\circ} 4$

Dibujo Clase B. Categoría 2. Plano de la Real Universidad de San Felipe, en Santiago de Chile, por Antonio Losada. Hacia 1750. (Archivo Nacional de Santiago de Chile) 
De la época que nos interesa, el Archivo de Santiago guarda planos de cárceles, de obras de mejoramiento urbano como los Tajamares del Mapocho y otras edificaciones públicas, elaborados por Joaquín Toesca.

Clase B, Categoría 3. Dibujo Científico: Incluye ilustraciones botánicas, zoológicas, entomológicas y antropomorfas de distinto tipo; ilustraciones de anatomía animal y humana normal y patológica; dibujo forense. La principal fuente la constituye la ilustración entomológica y botánica de Rodulfo Armando Phillipi, y las láminas de Gay pertenecientes a esta categoría incluidas en la carpeta ya mencionada como ejemplo en la clase B 1. 


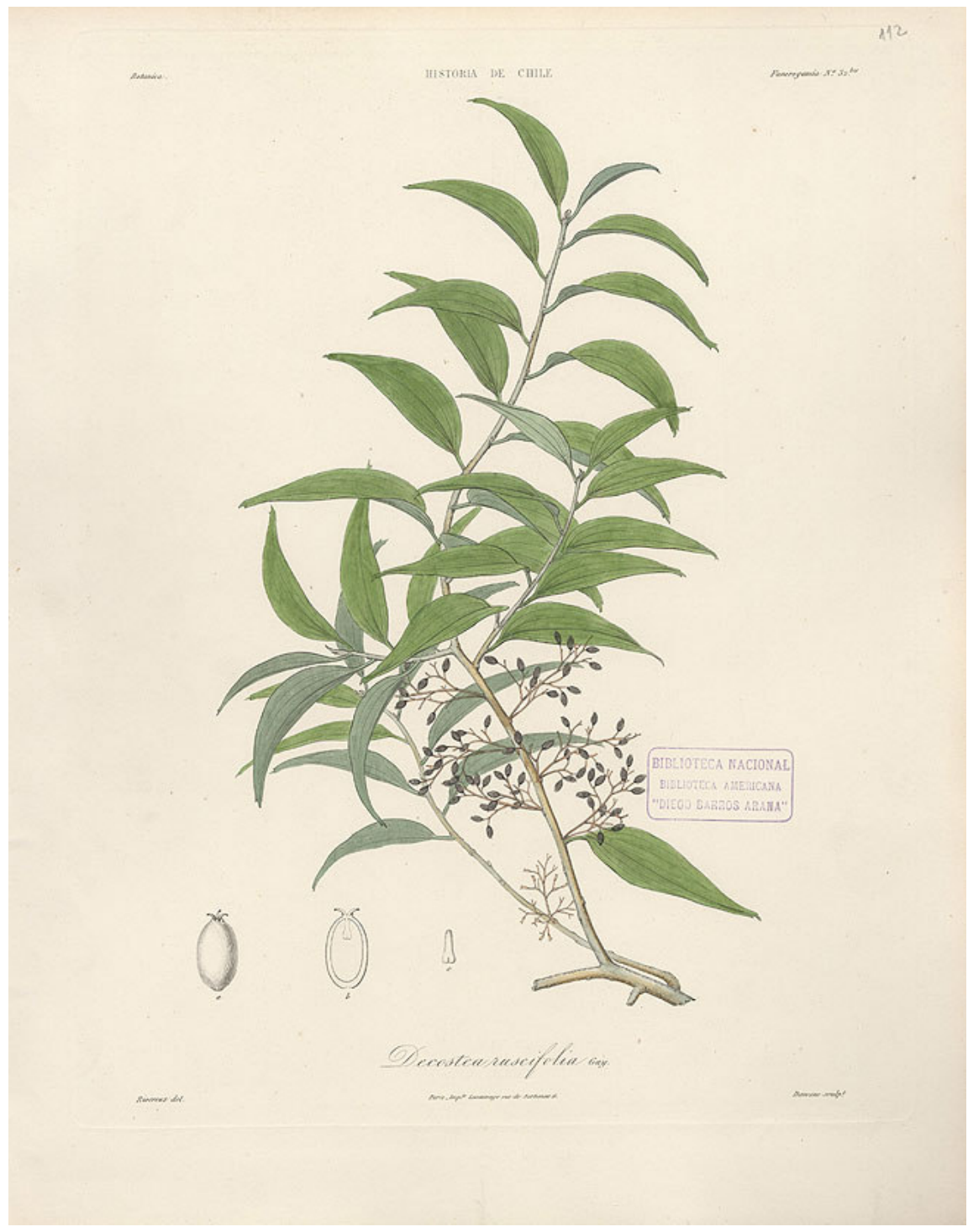

Lámina $\mathrm{N}^{\circ} 5$

Dibujo Clase B. Categoría 3. Ilustración de planta Costea Rustifolia del Album de Gay. 1854. 
Clase B, Categoría 4. Dibujo Social: Incluye caricaturas, descripciones de personas o hechos según usos y costumbres (nuevamente Gay; también y sobre todo M. Rugendas, ya mencionado). No obstante, la noción de caricatura no es manejada en Chile en el período de esta investigación; salvo por Rugendas, que hizo algunos dibujos de personajes con rasgos exagerados hacia 1840. La caricatura, propiamente tal, se conoce recién hacia mediados del siglo XIX.

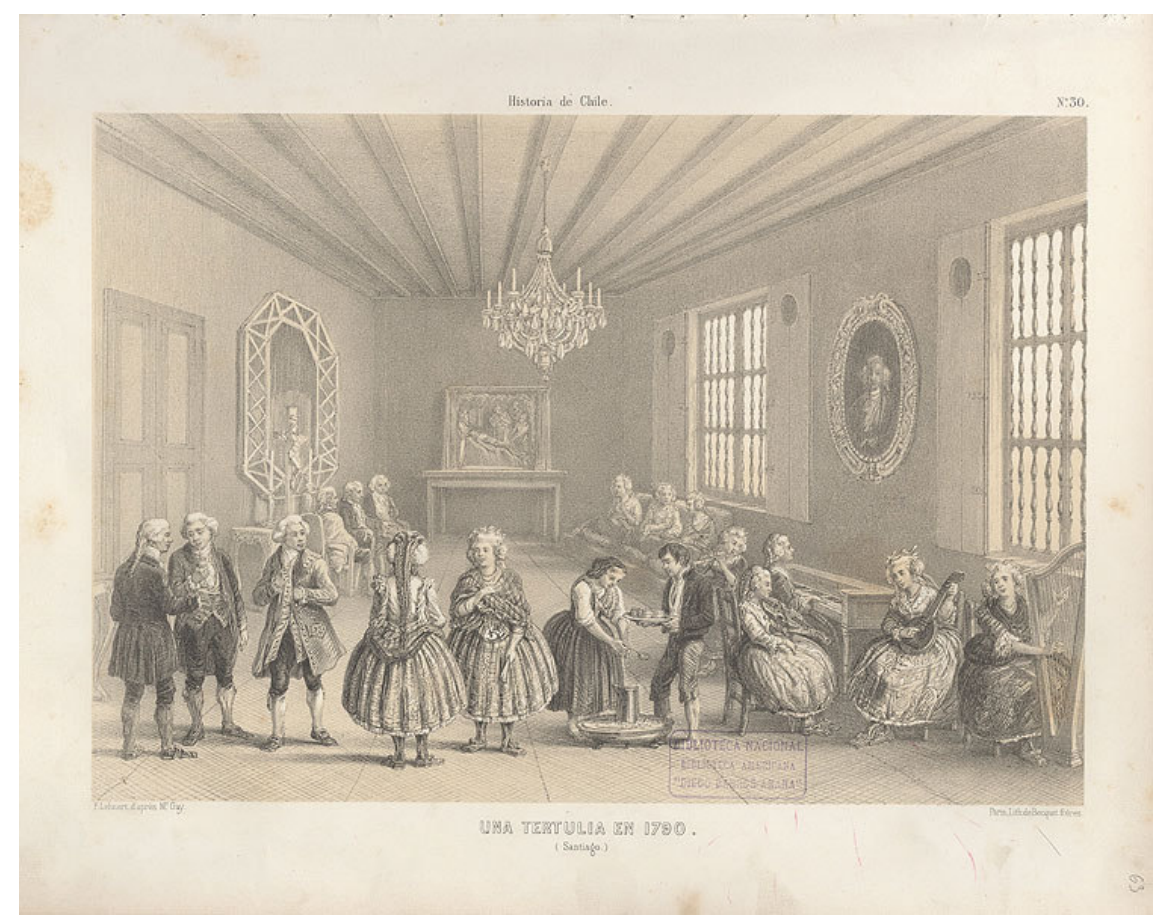

Lámina $\mathrm{N}^{\circ} 6$

Dibujo Clase B. Categoría 4. Una tertulia, de Claudio Gay. 1790. (Biblioteca Nacional de Chile) 
Clase C. Objetos-Dibujo como símbolo. Dibujos con o sin valor estético que además de su posible interés histórico como documento, posean en sí mismos un valor de culto por el peso simbólico. Se incluyen aquí los dibujos de populares de naturaleza religiosa (imágenes de santos) y los dibujos propios de los símbolos patrios o nacionales, o insignias ejecutadas según la definición ya enunciada. En esta clase se incluyen cartas manuscritas y bocetos de planos ejecutados por "próceres" o "héroes" nacionales, pues poseen valor de reliquia. Estos documentos se encuentran en el Archivo Nacional de Santiago de Chile. Sólo si la caligrafía es considerada una categoría de dibujo, estos documentos podrían incorporarse a un estudio del desarrollo del dibujo en Chile. 


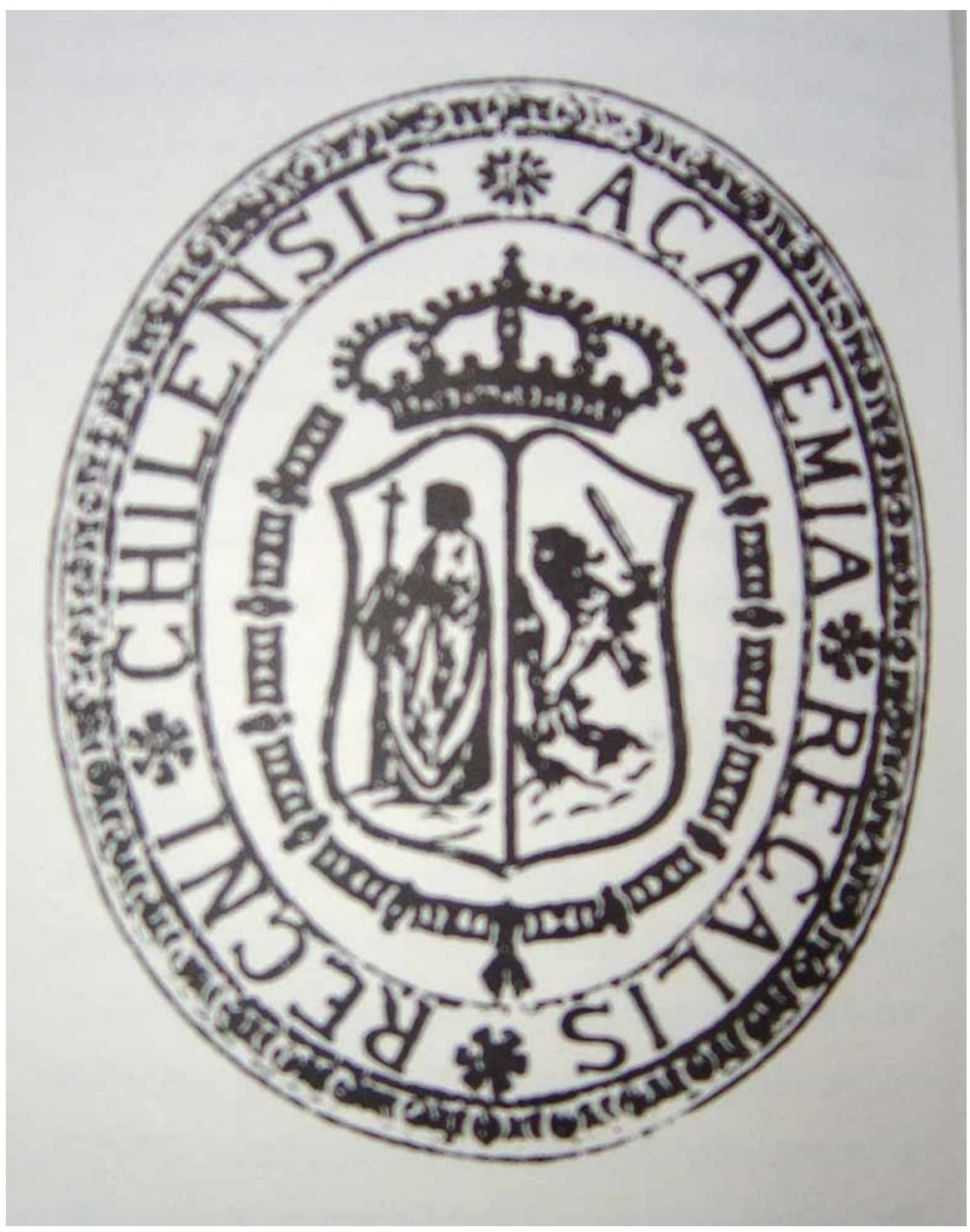

Lámina $\mathrm{N}^{\circ} 7$

Dibujo Clase C: Dibujo como símbolo. Escudo de la Real Universidad de San Felipe. (Biblioteca Nacional de Chile) 
Esquema que resume los campos de aplicación del dibujo en Chile. Siglos XVIII - XIX.
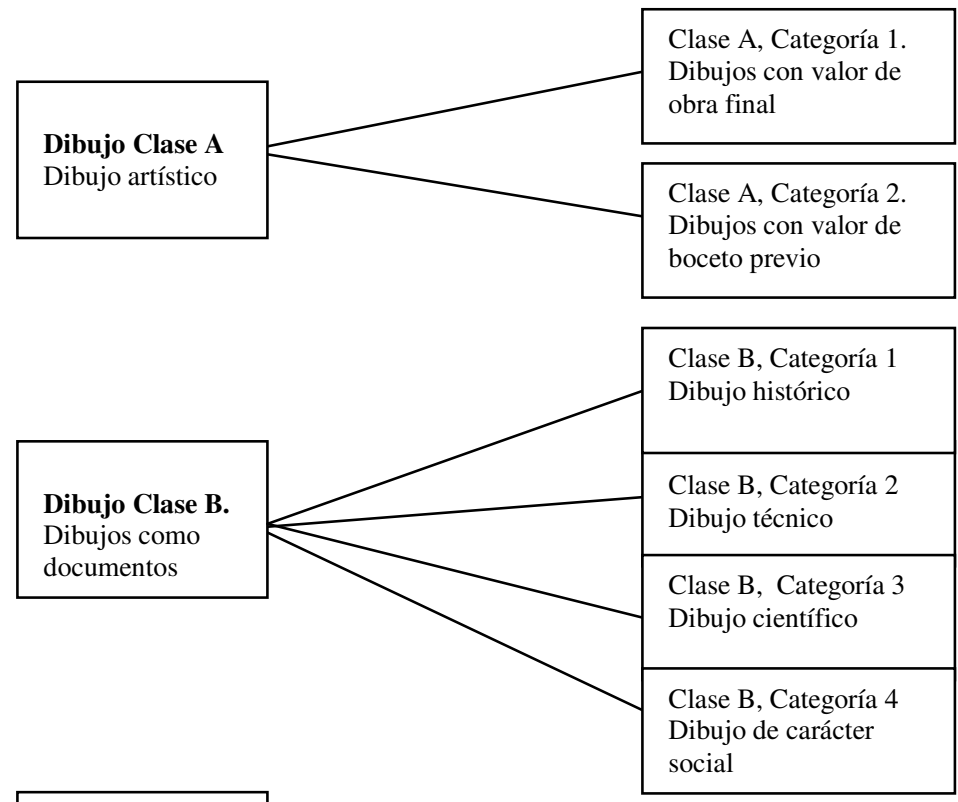

Dibujo Clase C.

Dibujos como

símbolos 



\section{CONTEXTO HISTÓRICO DE LA FORMACIÓN DEL PRIMER CURSO DE DIBUJO EN CHILE}

\section{II.1. Línea del tiempo 1745 a 1891}

Para efectos de contextualizar las ideas que aquí se expresarán y facilitar una correcta lectura y cruce de los hechos y sus circunstancias, me parece pertinente exponer en orden temporal los acontecimientos más importantes ocurridos en 146 años de historia. La línea del tiempo que expongo a continuación abarca el período que interesa a este estudio, pero incluye además los hechos ocurridos 52 años antes de la fecha con que se inicia esta investigación. La creación de la Real Universidad de San Felipe, marca el inicio de esta línea del tiempo, debido al valor fundacional para la enseñanza que tuvo en Chile esta institución. Se agregan a esta línea temporal, hechos relevantes posteriores a la creación de los cursos de pintura, escultura y arquitectura que constituyen el límite con el que concluye esta investigación, debido a la importancia de algunos hechos bélicos muy conocidos y de la creación de dos relevantes centros de estudio: la Universidad Católica de Chile en 1888 y la escuela de Bellas Artes en 1891. 
Línea del tiempo 1745 a 1891 
Esta hoja debe retirarse para insertar aquí el desplegable con la línea del tiempo y conservar así el correlativo de las páginas 
Una mirada al panorama del mundo occidental hacia fines del siglo XVIII, permite observar las condiciones culturales e ideológicas en las cuales se desarrollaron las ideas que conforman el sustrato teórico de esta investigación.

Las formas de instalación del Reino de España en Chile recibieron variadas influencias como resultado de la preponderancia política de distintos agentes y en distintos momentos. Esos asuntos impactaron en la generación de planes culturales en Chile.

Habiendo sido expulsados los jesuitas del Reino de España por orden de Carlos III en 1767, y disuelta esta orden por el edicto de Clemente XIV en 1773, Chile, que se organizaba culturalmente con una fuerte influencia de la Iglesia, acusó el golpe, con un retroceso del mundo de la cultura. Me refiero puntualmente a la gran capacidad demostrada en Chile por la Compañía de Jesús en la fundación de escuelas primarias o de primeras letras y en la creación de archivos y bibliotecas. Ese importante apoyo al desarrollo de formas básicas de institucionalidad cultural se detuvo abruptamente.

El mundo occidental comenzaba -en momentos distintos y de maneras distintas- a orientarse bajo las ideas la Ilustración. He creído pertinente realizar en las páginas siguientes una síntesis de la situación de Europa occidental en ese momento histórico, que permita contextualizar las acciones que se desarrollaban en Chile.

\section{II.2. El mundo europeo}

Dado que obviamente el "Nuevo Mundo" ha tenido una fuerte vinculación con Europa por más de 500 años, resulta pertinente abordar el panorama de ideas en el viejo continente y 
particularmente en España, para comprender posteriormente la manera en que éstas impactarían en el escenario de los últimos años de dominación directa del reino de España en Chile. Esta aseveración no implica negar que el impacto de dicha dominación fue mayor y más permanente, sólo que para efectos de esta investigación entendemos que en los últimos años del siglo XVIII y los primeros veinte del siglo siguiente, se vivió tal vez el cambio administrativo más relevante de la historia de Chile $^{31}$.

Hacia 1750, el principal asunto que ocupaba el espacio de las ideas en Europa eran las doctrinas racionalistas, que se propagaban como una respuesta al absolutismo del siglo anterior. Racionalismo e Ilustración irían de la mano en los años siguientes, conviviendo con los rezagos absolutistas que perdurarían en muchos países hasta el siglo XIX.

En la primera mitad del siglo XVIII la intelectualidad europea puso las bases de un pensamiento que no obstante declararse deísta $^{32}$, se oponía a cualquier forma de dominio divino sobre los estados y los individuos, lo que hace declarar a la Ilustración como una forma de pensamiento laico. Este rasgo resultó fundamental -como se verá en el desarrollo de esta investigación- para la transformación de la cultura en Chile. El desarrollo de la Ilustración -sabemos- no tuvo igual intensidad

31 No cabe duda de que el cambio en la forma como está organizada la administración de un país en sus aspectos más esenciales es un cambio político; a partir de esta aseveración habría que evaluar si la independencia de Chile del Reino de España y el golpe militar de 1973 son los dos hechos más relevantes en cuanto cambio de administración política del país, en toda su historia. 32 Término que hace referencia a la creencia en Dios pero no necesariamente en la Iglesia. El deísmo implica además una percepción personal de Dios y una interpretación personal de su manifestación, lo que básicamente significa optar por un alejamiento de cualquier forma de adoctrinamiento religioso. El dogma religioso, para un deísta, simplemente no existe, ya que privilegiará el uso de la razón para una interpretación de la manifestación de Dios. 
en los distintos países europeos. Destacan fundamentalmente Francia, donde el movimiento logró exponerse plenamente con La Enciclopedia de Diderot y D'Alembert ${ }^{33}$ y las ideas de Rousseau, Montesquieu y Voltaire; y Alemania, donde el movimiento fue conocido como Aufklärung, y donde la figura relevante de Kant permitió fundamentar los alcances de la razón para el desarrollo del hombre y la sociedad, asunto no menor que permeó las acciones de parte importante de la intelectualidad americana. En Inglaterra reconocemos a David Hume y a Adam Smith y su propuesta para una economía basada en el esfuerzo y la propiedad. En España, las figuras más relevantes fueron Jerónimo Feijoo ${ }^{34}$ y Gaspar M. de Jovellanos, a quienes revisaré en el punto siguiente.

La Ilustración impregnó los movimientos políticos y culturales de Europa y, por lo mismo, no tardó en propagarse entre los intelectuales del mundo, principalmente de las colonias, donde el poder de los imperios comenzaba a deteriorarse por la incidencia de los criollos, descendientes de los colonizadores, quienes comenzaban a ocupar cargos claves en la estructura del poder (Tribunales y Consulados). Cabe señalar que esta capa social criolla, fundadora de las familias más antiguas y adineradas de Chile, operaron con un estándar doble, por un lado la inserción en el aparto colonial, con diferentes fórmulas, les permitió generar y acumular abundantes riquezas y por otro lado al adquirir educación y cultura, fueron fácilmente motivados por las ideas y movimientos más avanzados de la época.

$33 \mathrm{Me}$ estoy refiriendo al más duro centro teórico que impulsa la Ilustración en Europa, personificado por Denis Diderot y Jean le Rond D'Alembert; Rousseau, Montesquieu y Voltaire. 34 Cfr. José Ferrater Mora, Diccionario de filosofía abreviado. Editorial Sudamericana, Buenos Aires, 1983478 p. 
Entre las principales características de la Ilustración podemos observar el nacimiento de un pensamiento optimista sobre el mundo, que abarcaba nuevas ideas en torno al desarrollo social y la noción de felicidad humana, esta vez desprendida del misticismo eclesial; la idea de justicia y la igualdad ante la ley y el Estado (derechos políticos y ciudadanos); la confianza en el conocimiento científico y en una cultura secularizada. Sin embargo, las antiguas formas de pensamiento persistieron en algunos países y zonas culturales por más tiempo que en otros, y allí sus representantes fueron denominados déspotas ilustrados. Entre quienes sostenían el poder político, este pensamiento básico, propio de la antigua estructura de ideas, comenzó a amalgamarse con las nuevas ideas de la Ilustración dando pie a un tipo de pensamiento y actuar que tomando los postulados de la Ilustración, los aplicaba en forma parcial. Las declaraciones acerca de gobernar con el pueblo y acercarse a él rápidamente se transformaron -en la práctica- en gobernar sin el pueblo. Todo para ellos pero sin ellos, contradicción que fue prácticamente disuelta hacia fines del siglo XVIII e inicios del siglo XIX con la desaparición de un grupo importante de gobiernos déspotas.

El mundo occidental comenzó a reemplazar las bases ideológicas establecidas hasta el momento. Los mitos culturales y científicos, los episodios oscuros relacionados con la justicia y la religión, y el conocimiento adquirido en el mundo antiguo comenzaron a disolverse, dando nacimiento a la idea de un ciudadano con derecho a la verdad, la felicidad, la justicia y el acceso a la adquisición de bienes personales y educación, con el consiguiente bienestar. En ciencias y artes surgen las ideas de "conocimiento", "razón" y "verdad", lo que actúa como un estímulo para el aumento de la cantidad y la calidad de los intelectuales: poetas, escritores, pintores, filósofos, arquitectos e ingenieros. La Ilustración cree en la naturaleza y el progreso permanente. No sería sino hasta fines del siglo XVIII que las nuevas ideas de Kant relativizaron las bases de la Ilustración, 
con postulados idealistas sobre la conducta humana, la noción de belleza y de naturaleza.

Un hecho fundamental ocurre en este siglo XVIII en materia de enseñanza. A raíz de las ideas antes planteadas por la Ilustración y el racionalismo, los contenidos de la enseñanza se establecen de manera más clara y con ello se adquieren y perfeccionan las metodologías. De este modo el principio de sistematicidad de la enseñanza se comienza a aplicar en los programas europeos y la noción de un sistema de enseñanza laico, comienza a imponerse como una forma viable y lógica para lograr la superación de la ignorancia, causa basal de la pobreza. Estos ideales de enseñanza, asociados obviamente a la adquisición del conocimiento y éste al desarrollo, resultaron un axioma básico de la Ilustración, y particularmente hacia fines del siglo XVIII en Francia fueron uno de los argumentos a favor de la Revolución Francesa y uno de sus posteriores impactos. En síntesis, los sistemas de enseñanza, los modos de enseñar, particularmente la sistematicidad del proceso y la acumulación del conocimiento para beneficio de los ciudadanos, constituyen un legado de esa época. De hecho la palabra "ciudadano" es una construcción de ese período.

A estas alturas, la noción de Bellas Artes aún es confusa, pero algunas ideas tomaban fuerza como concepción del mundo visual, particularmente se asentaba la idea de una construcción racional de los sentidos (Diderot).

En el ámbito del desarrollo de cursos y programas de Bellas Artes en general y dibujo en particular, en occidente se comenzaba a establecer una línea de investigación iniciada por 
el conocimiento previo ${ }^{35}$ desarrollado casi 200 años antes. Esa línea de ideas apuntaba a desarrollar aspectos como la forma, la composición, la óptica, el color, las nociones de belleza y su relación con la ciencia y las matemáticas. En estas materias el siglo XVIII europeo es particularmente aportador y rico en herencias recibidas de siglos anteriores y no son pocos los autores que en ese momento recogieron ideas previamente acuñadas para continuar con el desarrollo del conocimiento. Confeccionar un lista de autores y obras en estas materias siempre será poco exhaustiva o pobre, pero con el sólo propósito de reducirla a los documentos más relevantes y atingentes a esta investigación, cito algunos.

Descartes (1596-1650) había dejado como herencia su Geometría, que propone la representación de cuerpos según fórmulas que apuntan a la comprensión de ellos, más allá de su representación visual, y Jusepe Martínez su obra Discursos practicables del nobilísimo arte de la pintura, publicado a mediados de 1600. W. Hogart concluía en 1753 su The Analysis of beauty, with a view of fixing the fluctuating ideas of taste. Mathías de Yrala terminaba Método hacia 1739; Acisclo Antonio Palomino publicó en 1715 su obra en tres tomos Museo Pictórico y Escala Óptica, a la que nos referiremos en extenso llegados a la sección V de este documento. Andrea Pozzo publica en Roma en 1741 su obra Perspectiva Pictorum et Architectorum. Charles Batteux, escritor erudito, polígrafo, titular de filosofía griega y latina en el Collège de France y miembro de la Academia de Letras, publicaba hacia 1754 su obra Les Beaux-arts réduits à un même principe, que toca aspectos relacionados con la percepción, los métodos de dibujo, reproducción y pintura. Francesco Milizia publica en 1785

$35 \mathrm{Si}$ así pudiéramos denominar al trabajo reflexivo sobre la percepción, la representación, el dibujo y la pintura que realizaron G. Vasari (1511-1574), Miguel Angel Buonarotti (1475-1564), Alberti (1404-1472), Zuccari (1540?-1609), y tantos otros a partir del siglo XV. 
(Venecia) Los Principios de arquitectura civil; su Memorie degli architetti antichi e moderni (Venecia 1785) llegó a tener cuatro ediciones. En 1804 se publica su Dizionario delle belle arti del disegno ${ }^{36}$. En Berlín, Alexander Gottlieb Baumgarten publica Grundlagen der Ästhetik.

En el ámbito de las universidades, Europa es la que entrega a América la forma de estructurar la enseñanza por disciplinas. No podemos menos que reconocer la temprana creación y la larga trayectoria de las universidades europeas. La historia registra como una de las más antigua a la Universidad de Bolonia, cuya fecha de fundación aún se discute (para algunos fue fundada en 1159 por el emperador Federico I, para otros en 1088, fecha considerada oficial por la misma Universidad); la Universidad de Paris, que enseñaba -hacia el 1200- dialéctica, aritmética, geometría y nociones de astronomía; lo mismo Cambridge en 1208; o Palencia en 1212 y Salamanca en 1218. Hacia el siglo XVIII, esas instituciones estaban sobradamente consolidadas, lo que otorga a Europa un patrimonio de conocimientos que, como se verá más adelante, América conocería recién hacia el siglo $\mathrm{XV}$.

En síntesis: las transformaciones en Europa y sus resultados, impregnadas de los ejes del racionalismo y la Ilustración, impactaron fuertemente en el desarrollo de variados aspectos de la administración política, la vida cultural, la economía propia, así como en el desarrollo de la cultura y la administración de sus pueblos en ultramar (colonias americanas, en el caso que nos interesa aquí). Las ideas de "verdad", "autoridad" y de "felicidad" para los pueblos, contenidas primero en las pautas del empirismo, y luego en el racionalismo de la Ilustración generaron modificaciones en la educación, las leyes, la

36 Milano: P. Agnelli, dos volúmenes. 
administración del estado, y las formas de hacer ciencia y humanidades.

\section{II.3. España}

En España, el siglo se inicia con una nueva dinastía, la casa de Borbón, que sucede a la casa de Austria. Entre 1759 y 1788, Carlos III $^{37}$ ejerció un reinado absolutista en pleno período de la Ilustración. Los historiadores coinciden en que justamente por haber recogido algunos ideales reformistas propios de la Ilustración, y haber realizado reformas y cambios importantes en el modelo de Estado, Carlos III cabe en el modelo del déspota ilustrado.

No es menor el impacto del reinado de Carlos III en las Indias Occidentales (América), debido principalmente a que consolidó el dominio español, por la vía de permitir el desarrollo de los pueblos (virreinatos y capitanías) en pequeños pasos y proporción, bajo un sistema de administración que generó dependencia. Fue en su reinado que España debió protegerse de los intentos de control de América por parte de Inglaterra, y debió soportar a su vez el nacimiento de la clase intelectual en sus virreinatos, semilla que sembraría el descontento en la centuria siguiente.

Parece razonable suponer que las ideas de Carlos III acerca de la educación laica generaron en Perú y Chile un clima favorable para el desarrollo de formas de enseñanza seculares. Esta tendencia hizo declinar el desarrollo de las escuelas pertenecientes a las órdenes religiosas a favor de la división (años más tarde) de las escuelas y pequeñas iniciativas laicas de enseñanza, privadas primero y estatales después.

37 Perteneciente a la Casa Borbón. 
A la muerte de Carlos III, su hijo Carlos IV reinó en España hasta 1808. Fue un reinado lleno de agitación política interna y externa, con guerras y pactos. El escenario fue similar (y peor) durante el reinado de Fernando VII, también Borbón, quien había asumido la corona luego de la abdicación de su padre Carlos IV, quien, a su vez vivió exiliado en Bayona. Fue Napoleón Buonaparte quien intervino para que Fernando VII abdicara.

En materias de enseñanza, tomo una frase que a mi juicio explica de manera simple pero precisa la idea española del siglo XVIII, en el área de nuestra incumbencia: "En el ideal académico, existía la concepción de que la educación estética reunía a la vez la educación científica, la educación social y la educación moral" ${ }^{38}$.

Dichas ideas sólo se pudieron establecer con la presencia de figuras como Gaspar Melchor de Jovellanos y Jerónimo Feijoo. Este último desde la filosofía, expuso la doctrina de la moderación, que contemplaba frenar la creencia en una doctrina abstracta y, por el contrario, sostener la creencia en los hechos reales, lo concreto y científicamente probable y, por supuesto, la creencia en la exploración, la experimentación y la práctica instrumental, es decir lo opuesto a lo abstracto. De Jovellanos en tanto, impulsó -entre sus numerosas acciones en literatura, cultura y política- la creación de las sociedades económicas de amigos del país (España), institución singular que llegaría a América del Sur recién a mediados del siglo XIX.

38 Alegre, Antonio. La Enseñanza de las Artes. En: L'Academia de Santa Bàrbara i la Reial de les Tres Nobles Arts de Sant Carles. Facultad de Bellas Artes. Universidad Politécnica de Valencia. 2004, pp. 274-303. 
Basada en muchos de esos principios es que se crea, por ejemplo, en pleno periodo neoclásico (1754) la Academia de Santa Bárbara y la Real de San Carlos en Valencia. No obstante, el desarrollo europeo en materias de enseñanza superior ya estaba marcado por universidades como la Complutense creada en mayo de 1293, con el nombre de Studium General en Alcalá de Henares, o la ya mencionada en Salamanca, o Madrid.

\section{II.4. América del Sur}

\section{II.4.1. $\quad$ Aspectos geopolíticos}

En el siglo XVII todas las colonias de América del Sur estaban bajo el dominio de España, salvo Brasil. América se dividía en segmentos administrativos llamados virreinatos y éstos a su vez estaban divididos en unidades administrativas menores denominadas capitanías. Recordemos que hacia 1600 existía el gran virreinato de Nueva España, tal vez el dominio español de ultramar más grande que haya existido, ya que abarcaba desde México hasta Filipinas, incluyendo Guatemala, Santo Domingo, Cuba y Venezuela. Hacia el sur los territorios se denominaban Nueva Andalucía, Nueva Granada y Nueva Barcelona, respectivamente. Más al sur, se ubicaban el virreinato del Perú, creado en $1542^{39}$, y más tarde producto de la subdivisión de éste, hacia el Atlántico, el virreinato de La Plata.

39 La ordenanza suscrita por Carlos V en Barcelona el 20 de noviembre de 1542 crea el virreinato del Perú, y seis meses después nombra a Blasco Núñez de Vela como su primer Virrey. El 9 de diciembre de 1824, el ejército virreinal pierde la batalla de Ayacucho, lo que pone fin a más de 280 años de dominio español. El virreinato fue gobernado por 40 virreyes. 
En 1654, Holanda es derrotada en su intento de dominar Brasil, y se retira hacia el norte al territorio de Goianas ${ }^{40}$ pero manteniendo el control de las Islas Inútiles $^{41}$. Holanda termina estableciendo en el norte de América del Sur, junto al mar Caribe, la colonia existente hasta hoy. Francia hace lo propio en un territorio aledaño. Hacia 1715, el Caribe era el gran corredor del comercio de esclavos negros. Las incursiones por el control del norte del continente sudamericano concluyeron finalmente con la intervención de Inglaterra, Francia y Holanda, que se repartieron las Guayanas.

Como se puede ver, la preocupación de América del Sur estaba centrada en materias de administración y defensa de los territorios, más que en el desarrollo de los aspectos culturales, la educación o las artes. La vida circulaba aquí en medio de precarios sistemas de defensa frente a las grandes flotas navieras que recorrían el mundo en busca de territorios y fortuna para sus respectivas coronas. Si tuviéramos que ser drásticos, tendríamos que señalar que los ejes por los cuales se movilizaba en América del Sur el mundo colonial, eran el comercio y la defensa.

En materia de comercio e industria, América en general proveía de materia prima a Europa, tal como en gran medida hoy continúa haciéndolo. El Caribe con azúcar y tabaco, productos que años más tarde fueron demandados además a Colombia y Venezuela; el norte de América del Sur y Brasil con cacao;

40 Que hoy conocemos como Guayanas.

41 Conocidas hoy como Las Bahamas comprende además otras islas de las Antillas. Denominada así por el poco rendimiento que hizo de ellas España, que finalmente las abandona hacia 1700. 
México y Perú con oro y otros metales; Bolivia con plata y estaño.

\section{II.4.2. $\quad$ Aspectos culturales}

Un gran vacío en materias de enseñanza existía en estas tierras; ni abundante literatura, ni herencias sobre dibujo o pintura, ni conocimientos de propia producción se podían exhibir aquí en demasía. Las producciones literarias y visuales procedían de Europa y las que se generaban en suelo americano provenían de regiones muy apartadas entre sí como Perú, México o Venezuela, lo que impedía el conocimiento mutuo o la influencia entre ellas. No obstante, hacia la segunda mitad del siglo XVIII, una incipiente vida intelectual comenzaba a consolidarse en el área de la teología, la filosofía y la literatura, lo que ayudó a poner las bases de los sistemas de enseñanza formal en el siglo siguiente. Cabe destacarse que esta conjunción de disciplinas se mantenía, en esta zona, bajo el control político del catolicismo romano. Por lo mismo, y mientras las ideas de la Ilustración comenzaban a desarrollarse por intermedio de la clase dirigente, la filosofía pura continuaba en manos de las diversas órdenes religiosas y por esa vía se implantaba en el sistema universitario.

Dos importantes polos de desarrollo intelectual se pueden observar en América Latina de los siglos XVIII-XIX: se trata del Virreinato de Nueva España que incluyó México y lo que hoy conocemos como República Dominicana y el Virreinato del Perú.

Tres universidades podemos reconocer en esta extensa zona virreinal, las que siendo a su vez las más 
antiguas, dejaron una herencia académica en el continente. La Bula In Apostolatus Culmine, expedida en Roma por Su Santidad el Papa Pablo III el 28 de octubre de 1538, crea la Pontificia y Autónoma Universidad de Santo Tomás de Aquino en Santo Domingo. Las Universidades de San Marcos de Lima y Autónoma de México fueron fundadas en 1551. Estas universidades resultaron ser entonces los centros más relevantes para el desarrollo de la cultura, y por estar en poder de órdenes religiosas, la teología y como ya se dijo- la filosofía pura, eran sus principales focos de interés. No obstante, las Universidades de Lima y de México lograron hacia el 1700 ser verdaderos ejes de vida intelectual. Particularmente importante para Chile fue la Universidad de San Marcos de Lima, centro de formación superior al que acudía parte importante de la capa aristocrática y política del país y en cuyas aulas se desarrollaron muchas cátedras de filosofía aristotélica. El Colegio Máximo de San Pablo en Perú, por otra parte, llegó a ser el centro de enseñanza mejor dotado en bibliografía en todo el Virreinato, acumulando más de 40.000 títulos en su biblioteca en el momento de la expulsión de los jesuitas ${ }^{42}$.

En el área de la filosofía, es necesario detenerse un instante para señalar un hecho relevante: en América del Sur, la filosofía aristotélica fue el punto de contacto o denominador común de todas las instituciones de enseñanza regidas por el estado y las congregaciones religiosas ${ }^{43}$. En este sentido pareciera

42 Cfr. Hempe T., (compilador) La Tradición clásica en el Perú virreinal Lima: UNMSM, Fondo Editorial, 1999. 344 pp.

43 Ibídem, p. 55 
que este continente aún no toma verdadera conciencia de la importancia que tuvieron los comentaristas aristotélicos como Leonardo de Peñafiel en Perú, jesuita profesor del colegio de San Pablo de Lima, hacia mediados del siglo XVII, cuyas enseñanzas perduraron por muchos años o Jerónimo de Valera, quienes realizaron cátedras de filosofía, más que de teología, asunto no menor dado el fuerte dominio religioso en las instituciones de enseñanza. Este pensamiento puso las bases de la fortaleza de la orden jesuítica, que pese a su expulsión, logró consolidarse como un referente en materias de educación, persistiendo dicha fortaleza hasta el día de hoy. Es necesario destacar además a otros filósofos americanos, como el estudioso de Santo Tomás padre Francisco Suárez y el trabajo erudito del jesuita portugués Pedro de Fonseca, quien en 1632 había escrito un importante tratado de filosofía aristotélica denominado Commentarii in libros metaphysicorum Aristotelis Stagiritae.

En América del Sur, las ideas vinculadas a la aparición de la Ilustración tuvieron también como base y herencia la obra de peruanos y ecuatorianos del siglo XVI que desarrollaron un conocimiento humanista amplio y a veces hasta desprendido del componente católico. Tal es el caso de Pedro de Oña, que escribió la excelente crónica Arauco domado, o el Inca Garcilaso de la Vega ${ }^{44}$.

44 Entre otras obras publicó La Florida del Inca en Lisboa, en 1605, y la primera parte de los Comentarios Reales que tratan del origen de los Incas en 1609, que se conoció después como La Historia del Perú. 
Circularon también en América del Sur, por más de 100 años, la obra de Martín de Porres, Gaspar de Villarroel y Blas Valera entre otros, todos reconocidos como poetas, historiadores y cronistas, quienes produjeron un abundante material sobre historia de Sudamérica en ese período, asuntos todos que eran, como ya se dijo, los contenidos que circularon hasta mediados del 1700 .

Otra destacada figura que incrementó el acerbo cultural americano fue Felipe Guamán Poma de Ayala, cuya obra El primer nueva crónica y buen gobierno (sic) 1615-1616 consistió en una larga carta enviada al rey Felipe III de España, criticando las condiciones de vida de los indígenas del Perú. La obra contiene 1.200 folios y 400 dibujos ejecutados por el autor. 


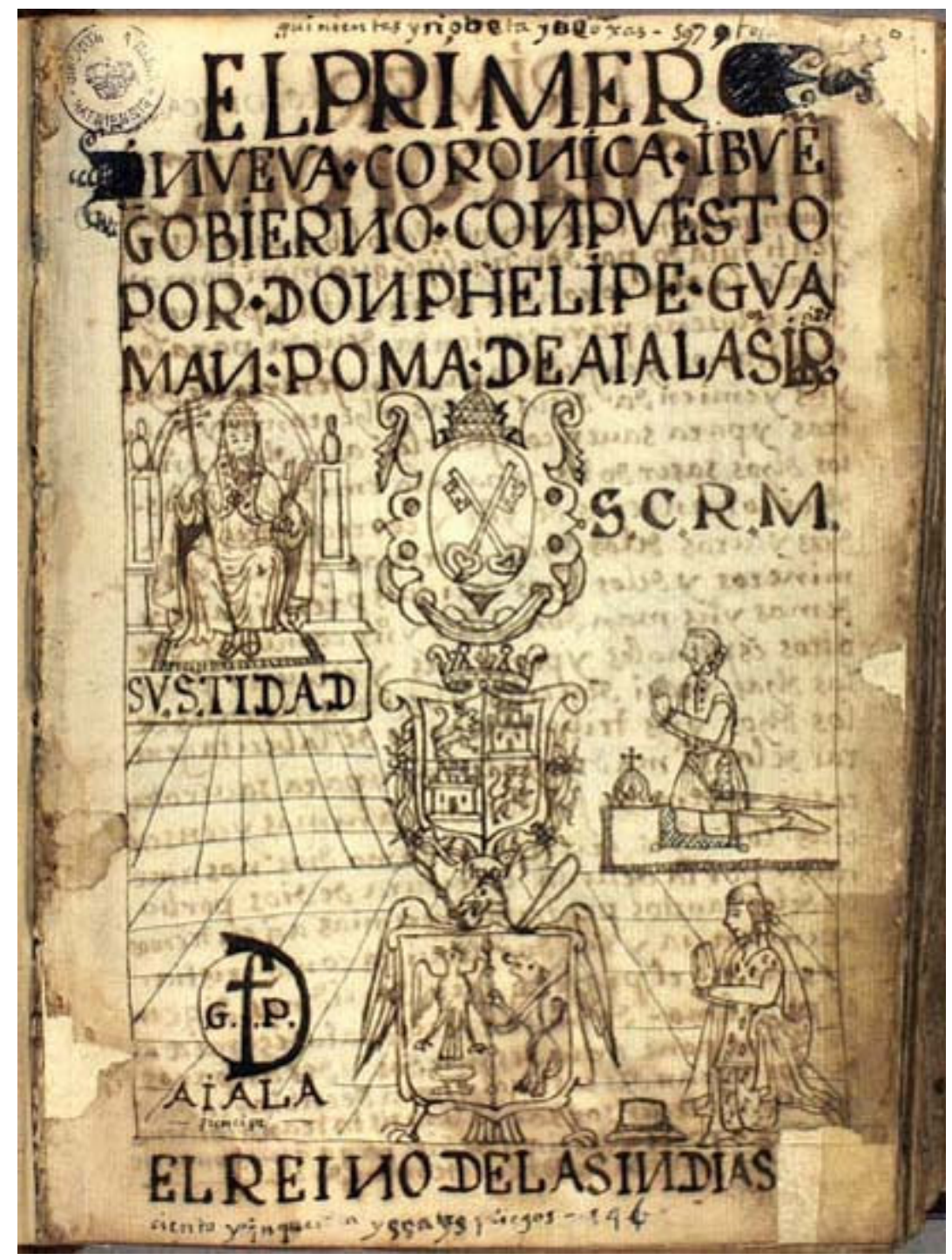

Lámina $\mathrm{N}^{\circ} 8$

Portada del libro de Felipe Guamán Poma de Ayala. El primer Nueva

Crónica y Buen Gobierno 1615-1616. 
Estos dibujos son particularmente valiosos por constituir una fuente directa de representación del habitante nativo de América, en contraposición con las imágenes idealizadas que circularon en Europa después de la llegada de Colón ${ }^{45}$ y que proliferaron luego con distinto grado de delirio en litografías confeccionadas en Londres y Paris.

Estas imágenes confeccionadas a partir de relatos, generaron además el respaldo que dio origen a innumerables relatos exuberantes sobre América.

45 Desgraciadamente esta valiosa obra textual y gráfica no tuvo mayor impacto en aquella época, ya que fue extraviada y sólo apareció 300 años después en Dinamarca. El documento se conserva en la Biblioteca Real de Copenhague y sólo fue dado a conocer por David Berry quien lo publicó en 1823. Esta obra resulta de un carácter similar al informe secreto que los científicos Jorge Juan y Antonio de Ulloa escribieron con motivo de su expedición a Sudamérica y que se conoce con el nombre de Noticias Secretas de América. Este documento fue publicado por la casa Juan de Zúñiga en Madrid en 1748. 


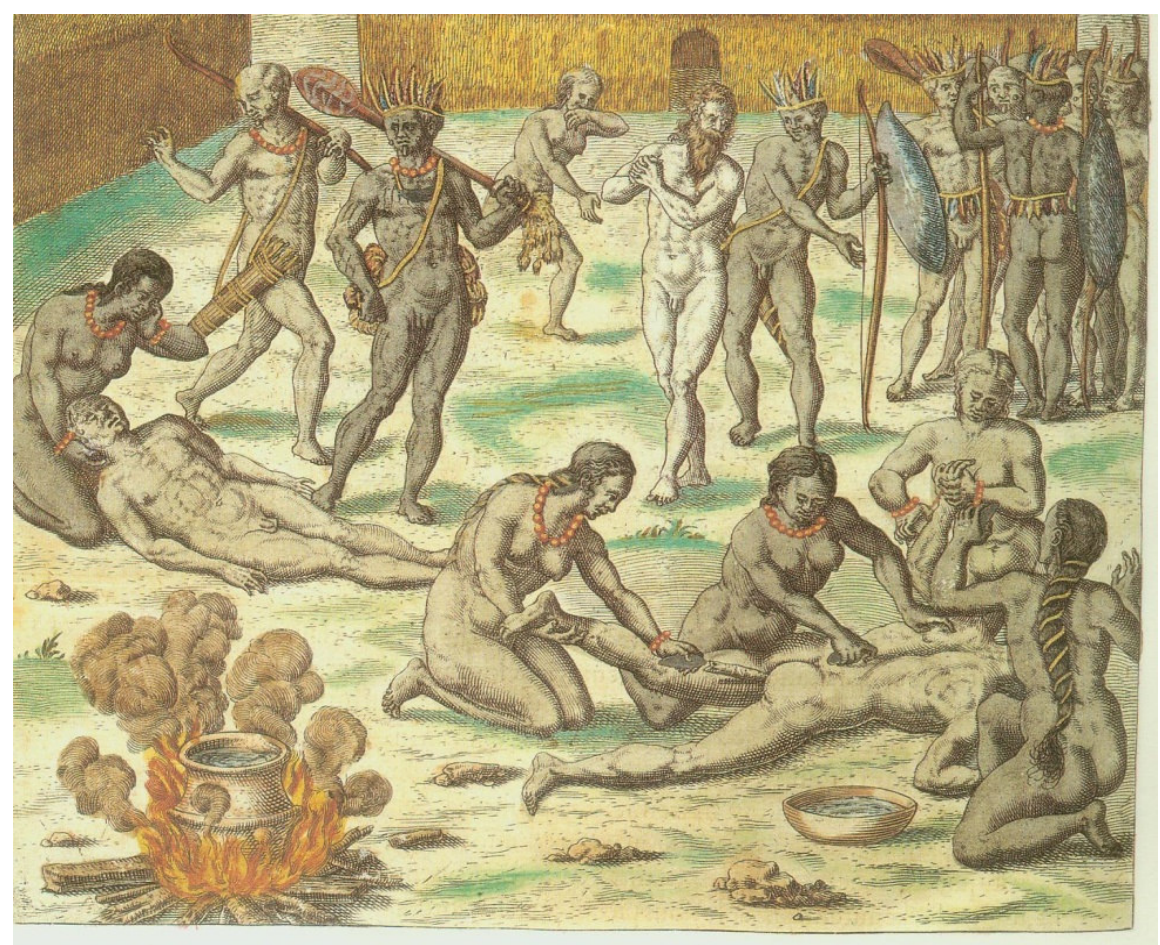

\section{Lámina $\mathrm{N}^{\circ} 9$}

Sacrificio de un prisionero. Lámina de Teodoro de Bry, libro tercero, tercera parte. Se trata de una imagen que muestra la forma en que una mujer indígena del Brasil, devora a su marido. Grabado en plancha de cobre, ejecutado entre 1556 y 1558. (Del Libro América de T.. de Bry) 


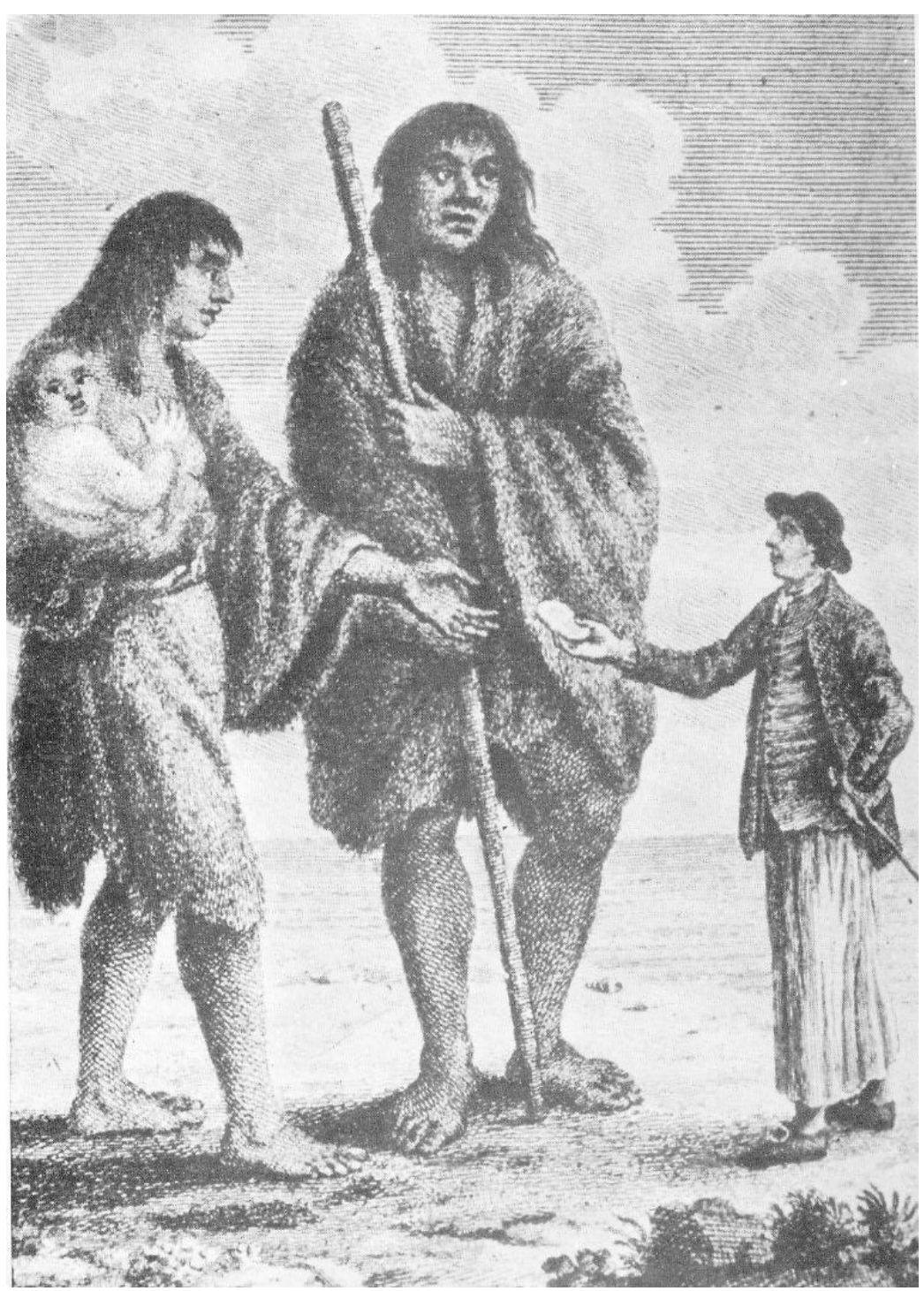

Lámina $\mathrm{N}^{\circ} 10$

Marinero dando una galleta a una mujer patagona. Atribuido a W. Hodges, del Byron's journal. Grabado en plancha de cobre, ejecutado entre 1764 y 1766. (Del libro La Imagen artística de Chile, de M. Rojas Mix) 
Es imposible revisar la herencia recibida por América del Sur sin mencionar finalmente la poderosa obra de Sor Juana Inés de la Cruz y de Carlos de Sigüenza y Góngora en México.

Entre los siglos XVII y XVIII la producción literaria de América imita en su desarrollo, la estructura literaria de Luis de Góngora y Luis de Tejada y Carvajal Robles en México.

Pese a la influencia que ejerció la obra de los grandes autores de siglos anteriores, el siglo XVIII en América no vio grandes luces en literatura, ni filosofía. Como ya dije antes, la vida en el continente sudamericano estaba fuertemente centrada en asuntos vinculados al comercio y la geopolítica, es decir, posibles nuevas distribuciones de las zonas de poder en función del debilitamiento de los imperios.

Pero volvamos a un aspecto central de la cultura de América del Sur. Un escenario muy particular se fue construyendo por un grupo de pintores en el alto Perú: se trata de la pintura cuzqueña.

Fuertemente vinculada a la Iglesia en sus inicios y más tarde a la aristocracia, la escuela de Cuzco, que dio origen al estilo "pintura cuzqueña", fue la matriz visual que dirigió las formas plásticas en el sector del Pacífico sur de América durante doscientos cincuenta $a_{n ̃ o s}{ }^{46}$. En efecto, esta escuela, que tuvo su origen con Juan Iñigo de Loyola hacia 1545, perfeccionó su

46 Como se verá más adelante, los rasgos que caracterizaron la pintura Cuzqueña desaparecen recién con la producción pictórica secularizada de José Gil de Castro y Pablo Rojas hacia fines del siglo XVIII. 
técnica y su desarrollo icónico, recibiendo en distintos momentos fuertes influencias de la pintura flamenca primero, italiana luego y finalmente española de corte manierista, tal como se describirá líneas más adelante. La pintura cuzqueña marcó, junto a la quiteña (es decir propia de la ciudad de Quito en Ecuador), un hito relevante en el estilo y el desarrollo de temas en la pintura sudamericana.

Potosí, en Bolivia, fue también un importante centro de trabajo pictórico en el período que revisamos ahora. Aunque de menor magnitud y producción que Cuzco, ambas estuvieron fuertemente vinculadas por su proximidad geográfica. De este sector del altiplano se destacaron artistas como Lorenzo Poveda, Luis Niño y Nicolás Chávez de Villafañe, quienes en sus obras presentan similares temas a los del Cuzco y algunas semejanzas en el tratamiento técnico asociado al manierismo. En la mención a esta zona denominada Alto Perú, debemos recordar que la aristocracia realista y la jerarquía de la Iglesia operaban en conjunto para efectos de la administración y el control de las haciendas, vinculación que contribuyó a establecer el sistema del encargo de obras. Esta práctica generó normas en las maneras de hacer pintura. Por esta causa no existe una notoria variedad en los temas y las técnicas, salvo al ojo más experto, que podrá determinar fechas a partir de los tipos de figuración, o variaciones leves del color.

Volviendo al Perú, es necesario señalar que desde mediados del siglo XVII y hasta principios del siglo XIX, la producción de obras en pintura se sostuvo bajo la fuerte influencia del pintor cuzqueño Diego 
Quispe Tito $^{47}$ y su escuela, que lograron marcar el punto de mayor desarrollo en la pintura de esta escuela andina hacia fines del siglo XVII. Los temas siguieron siendo los tradicionales asociados a vida de santos y en la iconografía abundan también las representaciones marianas, las que, en un análisis de los temas, resultan fuertemente sometidas a un canon, como los adornos y fondos de paisajes nunca andinos y bastante europeos. Respecto al dibujo podemos observar que es de corte realista, que intenta ser preciso en la morfología humana pero que sólo logra quedar como un dibujo ingenuo, precario y que generosamente podríamos calificar de expresionista. La pintura cuzqueña estuvo destinada fundamentalmente a la devoción religiosa, tal vez por ello el tratamiento de las vírgenes resulta casi como una reproducción bidimensional de las figuras de yeso; las telas incorporan dorados (brocateado) y colores rojo y amarillo de mucha saturación.

47 Cuzco, 1611. 


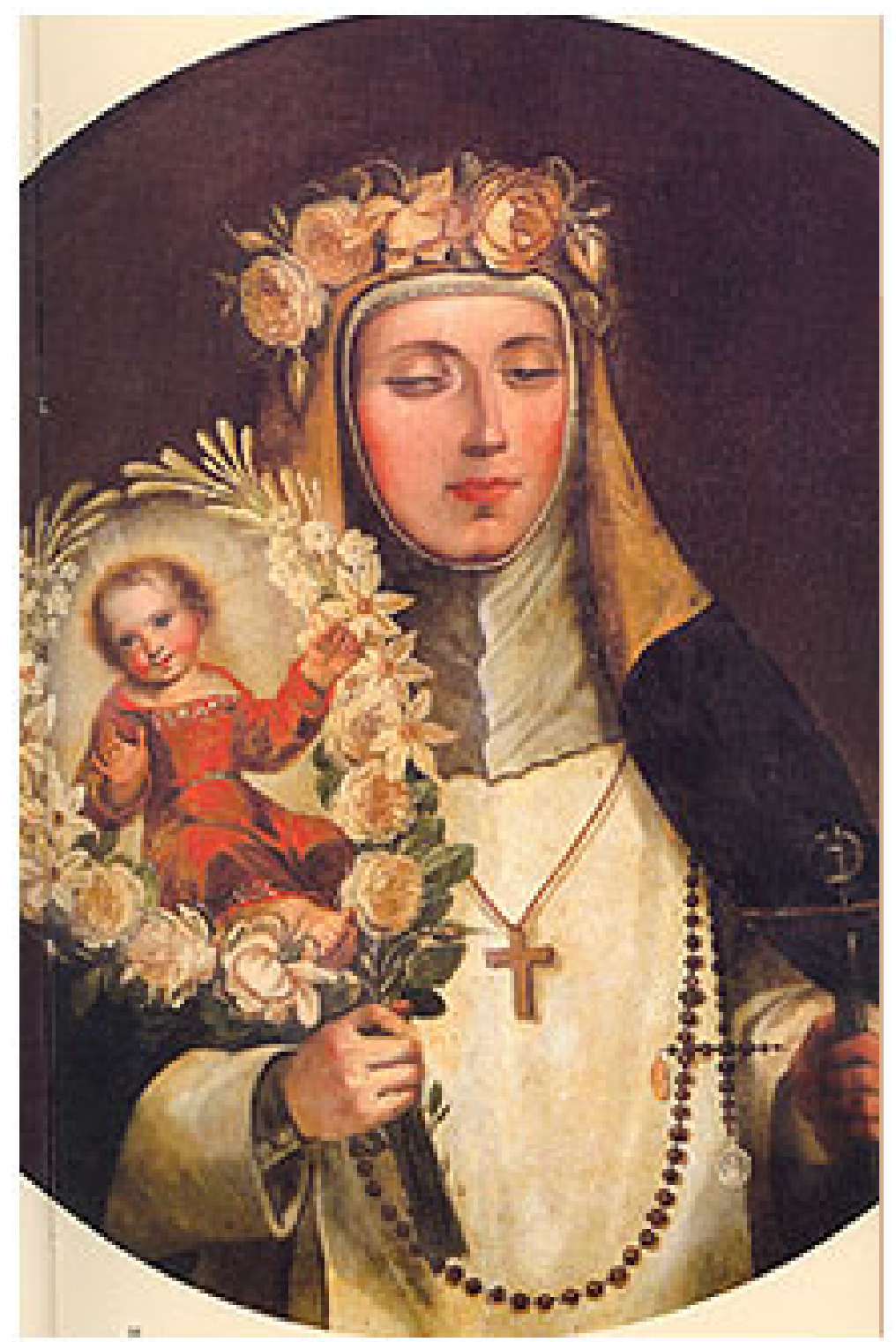

Lámina $\mathrm{N}^{\circ} 11$

Retrato póstumo de Santa Rosa de Lima. Angelino Medoro, 1617. (Basílica de Lima) 
Hacia la primera mitad del siglo XVIII, la pintura cuzqueña recibe influencias del barroco pero se desarrolla de manera bastante lenta sin cambios bruscos en las imágenes o técnica ${ }^{48}$. Dicha influencia fue sin duda heredada de Bernardo Bitti quien a fines del siglo XVI incorporó la "influencia italiana" a la escuela de Cuzco y por otros pintores como Quispe Tito, ya mencionado, y Angelino Medoro y prolongada en ese siglo por Marcos Zapata, Mauricio García y Delgado, Pedro Nolasco y García, e Isidoro Francisco de Moncada ${ }^{49}$ quienes fueron incorporando rasgos locales a las pautas europeas. Todas estas obras tienen en común los ya señalados rasgos: temas devotos y algunas constantes formales como el dorado, la eliminación de paisajes, la articulación de los cuadros mediante retratos sin perspectivas y con poco o nulo manejo del volumen y una fuerte dosis de mestizaje en los retratos.

Un hecho relevante y particularmente vinculado a esta investigación podemos detectar en la historia de la pintura peruana del siglo XVIII. Se trata de la escuela de dibujo y pintura que operó en Lima, desde el 25 de mayo de 1791, y que fue fundada por el pintor José del Pozo, miembro de la Academia de Sevilla ${ }^{50}$ e

48 Cfr. De Mesa, José y Gisbert, Teresa. El Arte en Perú y Bolivia (1800-1840). Universidad Mayor de San Andrés de Bolivia. Facultad de Filosofía y Letras. Centro de estudiantes. Publicaciones 4. La Paz. 1966. También en De Mesa, José; Gisbert, Teresa. Historia de la Pintura Cuzqueña. Fundación Augusto Wiese. Lima, 1982 Vol. 1317 pp. Vol. 2 233-830 pp.

49 Presidió el gremio de pintores y llegó a ser Alcalde Mayor del Cuzco según la investigación de De Mesa y Gisbert.

50 Varios croquis y una pintura de José del Pozo se registran en el catálogo del Museo Naval de Madrid. 
integrante de la expedición Malaspina a Chile, a la que me referiré en la sección II. 5.2. de este documento.

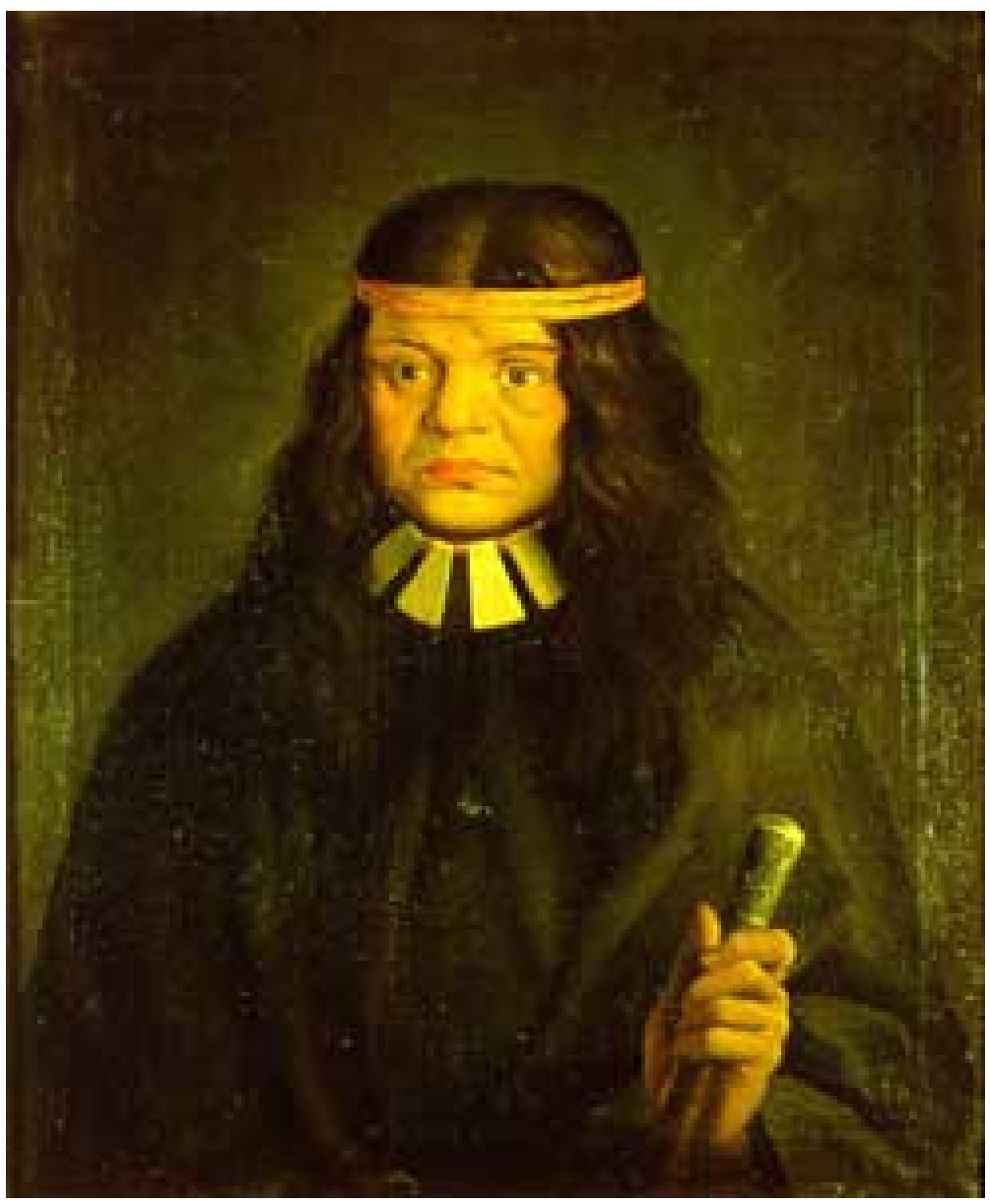

Lámina $\mathrm{N}^{\circ} 12$

Obra de José del Pozo. Oleo sobre tela 65 x 53 cms. 1790 aproximadamente. 
En esa misma época Lázaro de Ribera ${ }^{51}$ funda en Mojos, Perú, una academia de arte poniendo a la cabeza al pintor argentino Manuel Oquendo ${ }^{52}$. Los rasgos más relevantes de la pintura realizada al amparo de estas academias y que ya anuncia las características de la Ilustración, son el alejamiento de los temas religiosos y el acercamiento a una pintura histórica, social y de fuerte realismo en el tratamiento de los temas; se trata en pocas palabras, de una pintura de corte narrativo y austero.

A estas alturas la historia comienza a ser más clara: Perú fue un importante centro de producción cultural que irradiaba el conocimiento en el sector andino de América del Sur y que en materias de Bellas Artes señalaba a Chile el camino sobre las formas, temas y técnicas de la pintura.

Hacia fines del siglo XVIII aparece un artista que viene a renovar los temas mediante el abandono definitivo de la pintura religiosa. Se trata del pintor José Gil de Castro, conocido como el Mulato Gil ${ }^{53}$, quien junto a Pablo Rojas (1780-1840) se suma al cambio que ocurre en los sistemas de circulación de las obras de pintura, generando nuevos destinatarios (ya no sólo la Iglesia o los devotos) y cambiando el

51 Lázaro de Ribera fue Gobernador de Moxos o Mojos en 1794. Esta ciudad del Virreynato del Perú, ese denomina actualmente Departamento del Beni y pertenece a la República de Bolivia.

52 Ibídem, De Mesa y Gisbert. p. 181.

53 La fecha de su nacimiento varía según los autores. Antonio de Lavalle la ubica en 1783, en tanto De Mesa y Gisbert mencionan 1780. Del mismo modo, no está absolutamente establecida la fecha de la muerte de este pintor peruano que salió de Perú a los 12 años y residió en Chile más de 30. Se supone que hacia 1832 y luego de 30 años viviendo en el extranjero, vuelve a Lima donde fallece. Gil de Castro estudió pintura en la Academia de José del Pozo en Lima. 
tratamiento de las imágenes. La importancia y la pertinencia del Mulato Gil para esta investigación radican en que el inicio de su producción, a partir de su llegada a Chile en 1805, marca el fin de la pintura de influencia barroca y particularmente cuzqueña y señala el inicio de la pintura vernácula asociada a los intereses republicanos.

El Mulato Gil generó una obra destinada al consumo aristocrático, desvinculada totalmente de la Iglesia católica y cercana a su vez a la masonería ${ }^{54}$. El trabajo de este pintor lo acercó con fuerza al pensamiento de la Ilustración, dejando planteada la idea de una pintura laica, comercial (cobraba 60 pesos de la época por cada retrato), algo ingenua ${ }^{55}$, aristocrática y por lo tanto de élite.

No obstante, las formas de trabajo -técnicas e iconográficas- de estos artistas peruanos tienden a "españolizarse" hacia mediados del siglo XIX. Las influencias de Joaquín Sorolla serían evidentes en la evolución de esta pintura, pero esa es ya una historia diferente y ajena a nuestros intereses.

54 Mariátegui Oliva (1981) registra ocho lienzos del general José de San Martín, llamado Libertador de América, y cuatro de Bernardo O’Higgins, Gobernador Supremo de Chile luego de la caída del dominio español. Ambos militares mantenían fuertes vínculos con la Masonería (en Chile la Logia Lautariana o Lautarina), en una cadena de relaciones que vinculó a otros militares americanos protagonistas de los sucesos independentistas, lo que Salazar (2005) denomina el paso "al cesarismo militarista regido por la geopolítica continental de un club secreto". Ver. Mariátegui O., Ricardo. José Gil de Castro. El Mulato Gil. Vida y obra del gran pintor peruano de los libertadores. Lima, Perú. 1981. (sin editorial) 282 pp.

55 La pintura del Mulato Gil manifiesta poco desarrollo del dibujo, rostros de posición frontal tosca, manejo pobre de la perspectiva y posturas estandarizadas en sus retratados. 
En síntesis, Perú fue, como ya hemos dicho, una potencia en el área de la cultura y las artes, en el período que va desde la fundación de la Universidad de San Marcos en 1551 y hasta 1839, cuando pierde la guerra contra Chile ${ }^{56}$.

\section{II.5. Chile}

\section{II.5.1. $\quad$ Aspecto geopolítico}

Chile, por su ubicación geográfica -como capitaníaestaba bastante a resguardo -pero no exento- de las contingencias bélicas y la piratería y por esa misma causa ocupaba un lugar importante en el control estratégico de las naves que ingresaban desde Europa por Tierra del Fuego, en lo que hoy se conoce como Punta Arenas y la Patagonia. Este rasgo otorgó a esta capitanía su fortaleza, razón por la cual fue importante para España consolidar el dominio en la zona sur del país, lo que permitió la fundación de ciudades fortificadas como Valdivia o Chiloé. El panorama político llegó a ser desolador en estas latitudes, debido a una lenta y torpe administración colonial y sus modificaciones o adaptaciones a las circunstancias locales (guerras, terremotos, inundaciones). Inserta como colonia del Reino de España y en medio de los turbulentos cambios políticos y sociales que sacudieron a Europa (Revolución Francesa en 1789 y prisión de Fernando VII en 1808), la Capitanía General de Chile comenzó a desprenderse del dominio

56 La guerra entre Chile y la Confederación Perú Boliviana duró poco más de dos años, entre diciembre de 1836 y el 20 de enero de 1839 cuando la Confederación es derrotada en la Batalla de Yungay. 
español con mucha lentitud y sólo se logró en el siglo XIX, una vez generada la alianza militar conocida como el "Ejército Libertador". En el período colonial, una serie de gobernadores españoles ejercieron el gobierno aquí, algunos de los cuales generaron -en beneficio de España- un lamentable retraso en la estructura administrativa, económica y cultural de la región.

No comparto las ideas del historiador chileno Sergio Villalobos ${ }^{57}$ cuando sostiene que hacia $1700 \ldots$ “...el gobierno de Chile estuvo en manos de gobernadores prestigiosos que, en conjunto, fueron un claro repunte sobre sus predecesores. Funcionarios de carrera, honrados, atentos al progreso de la Colonia, dejaron la huella de su acción o cuando menos el recuerdo de su bondad. Los historiadores se han referido a ellos como < buenos gobernadores $>$..." 58

De la lista de gobernadores que podemos organizar a partir de los registros del Archivo Nacional ${ }^{59}$, Ibáñez

57 Me refiero a, historiador chileno contemporáneo. Las afirmaciones Sergio Villalobos acerca de que gobernadores de la época (fines del siglo XVII) tuvieron un mejor comportamiento que sus predecesores, no resultan hoy más que una aseveración condescendiente, ya que del total de gobernadores, los 3 que pudieron destacarse por gestos nobles, no logran cambiar el rasgo negativo, abusivo y corrupto que en su conjunto destacó al grupo de gobernadores españoles en esta Capitanía. Estos rasgos se exacerbaron con los últimos, Mariano Osorio y Marcó del Pont, a quienes les correspondió organizar a los ejércitos para las batallas por la reconquista hacia 1814 . 58 Ver, Villalobos, Sergio. Historia de los Chilenos. Tomo 1. Santiago de Chile, Taurus. 2006, p. 289.

59 En el transcurso de este trabajo nos referiremos permanentemente a diversos períodos de la historia de Chile, mencionando a sus gobernadores, quienes en los documentos consultados son 
de Segovia y Peralta, De Ustariz, Marcó del Pont, Osorio, García Carrasco, por nombrar sólo a algunos, dejaron una larga estela de robos, arbitrariedades, muerte y persecuciones. No podemos decir que en 100 años (1700-1800) los gobernadores españoles en Chile hayan favorecido el desarrollo del país. Cuando las acciones gubernativas fueron positivas para la región, fue por conveniencia de la corona o por iniciativa de la clase criolla intelectual, política, religiosa y acaudalada. Revisando los documentos, queda claro que Ambrosio O'Higgins y Manso de Velasco destacaron por su preocupación por la fundación de

llamados también presidentes. A continuación, detallo la lista de autoridades que ejercieron el gobierno colonial por mandato de la corona, desde 1700 y hasta el término del dominio español: Francisco Ibáñez de Segovia y Peralta (diciembre 1700 - febrero 1709); Juan Andrés de Ustariz de Vertizberea (febrero 1709 - diciembre 1716); José de Santiago Concha y Salvatierra (diciembre 1716 - diciembre 1717); Gabriel Cano y Aponte (diciembre 1717 - noviembre 1733); Francisco de Sánchez de la Barreda (noviembre 1733 - mayo 1734); Manuel Silvestre de Salamanca Cano (mayo 1734 - noviembre 1737); José Antonio Manso de Velasco (noviembre 1737 - junio 1744); Francisco José de Ovando (junio 1745 - marzo 1746); Domingo Ortiz de Rosas (marzo 1746 diciembre 1755); Manuel de Amat y Junient (diciembre 1755 - septiembre 1761); Félix de Berroeta (interino, septiembre 1761 - octubre 1762); Antonio de Guill y Gonzaga (octubre 1762 agosto 1768); Juan de Balmaseda y Censano Beltrán (agosto 1768 - marzo 1770); Francisco Javier de Morales (marzo 1770 - marzo 1772); Agustín de Jáuregui y Aldecoa (marzo 1772 - julio 1780); Tomás Alvarez de Acevedo Ordaz (julio 1780 - diciembre 1780 y luego abril 1787 - mayo 1788); Ambrosio de Benavides (diciembre 1780 - abril 1787); Ambrosio O’Higgins (mayo 1788 - mayo 1796); José de Rezabal y Ugarte (mayo 1796 - septiembre 1796); Gabriel de Avilés y del Fierro (septiembre 1796 - enero 1799); Joaquín del Pino Sánchez de Rojas (enero 1799 - abril 1801); José de Santiago Concha Jiménez Lobatón (abril 1801 - diciembre 1801); Francisco Tadeo Diez de Medina Vidanges (diciembre 1801- enero 1802); Luis Muñoz de Guzmán (enero 1801 -febrero 1808); Juan Rodríguez Ballesteros (febrero 1808 - abril de 1808); Francisco Antonio García Carrasco Díaz (abril 1808 - julio 1810); Mateo de Toro Zambrano y Ureta (julio 1810 - septiembre 1810 ); Mariano Osorio (1814-1815); Casimiro Marcó del Pont Ángel Díaz y Méndez (1815febrero 1817). 
nuevas ciudades, el desarrollo del comercio y algunos aspectos de la administración, pero esos casos no alcanzan a prestigiar a los gobiernos reales.

A partir de la revolución en Francia, diversas ideas liberales comienzan a extenderse en esta región. Los intelectuales de la época que habían servido al rey ya comenzaban a darle la espalda con cierto disimulo, siguiendo la causa de la independencia. Hacia fines del siglo XVIII, la tradición jesuítica barroca, principalmente venida de Baviera, era reemplazada por la ideología librepensadora de Francia. Este hecho influirá posteriormente en varios asuntos no menores en la marcha del sistema social, político, educacional y cultural, tal como se explica en el capítulo IV del presente documento.

Uno de ellos es la noción de libertad de trabajo, que marcha casi en conjunto con la Ley de Libertad de Vientre, que implica ni más ni menos que la abolición de la esclavitud en Chile, decretada en 1811. Otro es la separación de la Iglesia con respecto al estado y con ello, la disminución de la influencia de la Iglesia en las decisiones del poder político y las libertades de los individuos. El tercero es la idea desarrollista impulsada principalmente por los criollos que denominaré "revolucionarios" y que finalmente resultaron ser la estirpe intelectual que, apoyada en esta idea, da curso al desarrollo económico, al desarrollo de la cultura y, por ende, de la educación. 
El libro de Pereira Salas Historia del Arte en el reino de Chile $^{60}$ resulta ser el documento más completo por el detalle historiográfico pero lamentablemente -para efectos de esta investigación- centrado en asuntos vinculados a la arquitectura. No obstante, de una lectura detallada de esta obra podemos constatar que preocupación de los gobernantes en el siglo XVI se centraba en la consolidación de una ciudad, en el siglo XVII en el fortalecimiento de la administración del reino y en el siglo XVIII en el mejoramiento de la administración (justicia, gobierno central, urbanismo); sin embargo, en el siglo XIX, el trabajo, la educación y la salud, comenzaron a ser los motores de la actividad estatal. Comparto la idea de que las preocupaciones que movían al aparato administrativo variaron con el paso de un siglo a otro, lo que explica el descuido por el tema cultura-enseñanza hacia el siglo XVIII.

En la medida que se fortalecía el estado, la Iglesia que había llegado a ser preponderante en el sistema administrativo y político del Reino en los siglos XVI y XVII, fue decayendo en poderío hacia el siglo que nos interesa, el XVIII.

Hacia mediados del siglo XVIII surge la idea desarrollista de aumentar la mano de obra especializada y con ello la idea de regular el funcionamiento de los gremios, asunto que se analizará más adelante.

60 Pereira Salas, Eugenio. Historia del Arte en el reino de Chile. Santiago de Chile, Ediciones Universidad de Chile. 1965. 497 páginas. 
Por otra parte, la fuerte motivación del poder central por controlar a las poblaciones indígenas y mejorar las faenas agrícolas y mineras, generó en el siglo XVIII un fuerte repunte en la consolidación de las ciudades y pueblos. Si en un comienzo el movimiento de pobladores fue colonizador y por lo mismo se dio de manera centrífuga para efectos de copar el territorio, en el siglo XVIII se dio de manera centrípeta, pues el gobierno central trató de agrupar las poblaciones para efectos de aumentar su control sobre ellas ${ }^{61}$.

\section{II.5.2. $\quad$ Aspectos culturales}

Llama la atención que acerca de Chile, más sabían los europeos que los propios chilenos, aunque dicho conocimiento no siempre fue preciso. Una anécdota ilustra perfectamente esta idea. En 1629 llegó a Chile el sacerdote jesuita Diego Rosales, quien fue el autor de una importante obra escrita hacia 1660, que describe Chile desde el punto de vista geográfico y social: La Historia Jeneral del reino de Chile (sic). El documento sólo se conoció en Chile hacia fines del siglo XIX, pero había circulado hasta entonces en algunas bibliotecas y librerías europeas. La herencia de Rosales fue similar a la que dejaron otros historiadores o cronistas $^{62}$ que habían visitado este lugar, los cuales buscaron fortalecer la identidad de este rincón de América, cuya imagen en Europa

61 Villalobos, Op. Cit., p. 215.

62 Una interesante discusión al respecto plantea Germán Colmenares en su libro Las Convenciones contra la cultura, pp. 53-57. (Centro de Investigaciones Barros Arana, Dirección de Bibliotecas Archivos y Museos de Chile. Santiago de Chile, 2006). 
circulaba con una fuerte carga de mitos y leyendas ${ }^{63}$, tal como ya se señaló en el punto II, 4.2. Esa visión cultivada durante años persistió durante el siglo XIX, "Durante el siglo XIX el esfuerzo por ver la realidad americana debía seguir dependiendo de las convenciones historiográficas europeas" ${ }^{24}$.

Desde el punto de vista cultural, Chile se desarrollaba principalmente en Santiago, en una vida centrada en grandes haciendas, con una ciudad de centro pequeño destinada a la administración de gobierno. Hacia mediados del siglo que nos interesa, la vida intelectual y social era muy limitada, la existencia del primer periódico data recién de 1812 (13 de febrero) y la actividad en torno a la literatura, las Bellas Artes y la música era bastante restringida y ocurría principalmente en círculos cerrados de la aristocracia santiaguina.

Otros autores relevantes que aportaron al conocimiento y particularmente a la historia de Chile fueron: Alonso de Ovalle, jesuita autor del libro Histórica relación del Reyno de Chile $i$ de las Misiones i Ministerios que exercita la Compañía de Jesús (sic) (1646); Juan Ignacio Molina, también jesuita, autor de la magnífica obra Ensayo sobre la historia natural de Chile (1782); y Pedro Usauro

$63 \mathrm{Al}$ respecto consultar a Rojas Mix, Imagen Artística de Chile, Ed. Universitaria, Santiago de Chile, 1969. Dicha obra revisa la imagen de Chile colonial en Europa. También es relevante considerar en este aspecto que parte importante de las ilustraciones que se hicieron en el siglo XVII y que ayudaron a "organizar" una imagen de Chile en el extranjero, se realizaban en talleres europeos de artesanos estampadores y artistas ilustradores franceses y españoles. Ver láminas $\mathrm{N}^{\circ} 9$ y 10 en II.4.2, en este documento.

64 Colmenares, Op. Cit. p. 55. 
Martínez de Bernabé, militar de carrera, que escribió dos importantes obras que ayudaron a describir de manera acertada y desde variadas perspectivas la ciudad de Valdivia: Relación Histórica de la plaza, presidio, puerto y ciudad de Valdivia de 1780 y La verdad en Campaña de 1782.

A fines del siglo XVIII llega a Chile la expedición de Alejandro Malaspina. Este italiano, al servicio de la corona española, realizó entre 1794 y 1798 una de las expediciones más completas del siglo XVIII y la última que realizara el imperio español en posesión de sus tierras en las indias occidentales ${ }^{65}$. A bordo de sus naves Atrevida y Descubierta, viajaron eruditos de todo tipo; el cartógrafo Felipe Bauzá, los naturalistas Antonio Pineda, Luis Née y Thaddaeus Haencke; el astrónomo Dionisio Alcalá Galeano y José Guío y Sánchez, José del Pozo, Fernando Brambila ${ }^{66}$, Juan Ravent y el valenciano Tomás de Suría, quienes como pintores y dibujantes, ejecutaron imágenes que muestran la vida social, describen la arquitectura y realizan ilustraciones botánicas y zoológicas. Me atrevo a señalar que esta expedición fue tal vez la de más alto nivel en cuanto a la calidad de sus integrantes y las áreas del conocimiento que abarcaban.

65 La suerte de A. Malaspina no fue de las mejores. Entregado su informe y la suma de mapas, dibujos y estudios botánicos, cartográficos, hidrográficos y zoológicos, agregó un informe político donde sugería mayor libertad para los naturales de estas tierras. En una purga política fue apresado, considerado traidor y mantenido prisionero durante algunos años. Los documentos fruto de esta expedición se encuentran dispersos; en Chile hay sólo un par de dibujos de José del Pozo y Fernando Brambila.

66 Es pertinente mencionar que a este autor pertenece el Tratado de Principios elementales de perspectiva, publicado por la Academia de San Fernando en 1817. 
Lamentablemente no existen documentos que prueben que en Chile la expedición dejó una fuerte huella intelectual. La expedición estuvo poco tiempo en Valparaíso, la Patagonia y Santiago y sus integrantes tuvieron al parecer poco contacto con chilenos, lo que impidió que -a diferencia de lo que sucedería en el siglo siguiente con Rugendas, A. Humboldt, Gay o Phillipi- pudieran dejar una herencia de $\operatorname{conocimientos}^{67}$. No obstante, sabemos que la producción de los naturalistas y dibujantes se encuentra repartida en diferentes colecciones de América y Europa. De Fernando Brambila sólo se conocen en Chile algunos dibujos y grabados que se conservan en el Museo Histórico Nacional de Santiago de Chile.

67 De dicha expedición, Haencke fue el único que se radicó en el continente; se estableció en Bolivia y aportó a ese país sus conocimientos como químico, naturalista, historiador y médico. Falleció en 1816 en Cochabamba, Bolivia. 


\section{ORIENTACIONES ESTETICAS EN CHILE EN EL PERIODO ESTUDIADO}

\section{III.1. En la arquitectura}

Por la construcción de edificios seculares del tipo militar y que avanzaron a la par con la arquitectura religiosa, podemos conocer los estilos y tendencias arquitectónicas más definidas. Es muy sabido aquí que lo que hoy podemos identificar como del tipo mudéjar y plateresco ${ }^{1}$, en la pobre arquitectura civil del siglo XVII, resulta más bien un híbrido de influencia gótica en algunos casos, toscana en otros y por sobre todo del bajo renacimiento italiano, estilo que perduraría hasta avanzado el siglo XVIII' ${ }^{2}$.

El neoclasicismo se comienza a imponer en Chile a fines del siglo XVIII, principalmente con la llegada de Joaquín Toesca, arquitecto italiano que definitivamente se radica en el país al servicio del gobierno y que luego ejerce gran influencia en las actividades intelectuales en Chile. No obstante Guarda ${ }^{3}$, jesuita historiador de la arquitectura chilena, señala que Toesca no hizo más que continuar con el barroco clasicista italiano. Se desprende de tal aseveración que, si bien existió una diferencia entre las distintas versiones sobre el modelo arquitectónico de Joaquín Toesca, lo que queda claro es que el neoclasicismo apenas comenzaba a imponerse en Chile en 1782, fecha en que

1 Los pórticos y ornamentaciones de la Iglesia de San Francisco en Santiago de Chile, de 1572 y

aún en pie, son un buen ejemplo de estos estilos.

2 Pereira Salas. Op. Cit., p. 34-53

3 Cfr. Guarda, Gabriel. Historia Urbana del Reino de Chile. Santiago de Chile, editorial Andrés Bello, 1978. 1997. 
los planos del Palacio de la Moneda ${ }^{4}$ de Santiago estuvieron terminados. Este asunto no es menor; y lo que es preciso subrayar es que, si bien en esa época Europa estaba en pleno momento noeclacisista, el movimiento avanzaba sobre Latinoamérica con considerable atraso; por su parte, la corona de España no aplicaba necesariamente las ideas neoclásicas en sus construcciones de la misma manera y con la misma energía con que lo hizo Francia.

La tardanza en la difusión del estilo neoclásico sobre las colonias españolas en América, es lo que lleva a suponer que las obras ejecutadas aquí sólo podrían corresponder al neoclásico con posterioridad al 1800. Dicha influencia abarcaría incluso a la pintura.

\section{III.2. En Bellas Artes}

Las disciplinas o técnicas más recurrentes en materia de Bellas Artes $^{5}$, antes de la creación en Chile de los cursos de pintura (4 de enero de 1849) y arquitectura (17 de noviembre de 1850), eran naturalmente el dibujo y la pintura.

La práctica del dibujo tuvo lugar principalmente en la arquitectura, en la cual el ejercicio de la disciplina se centraba en la puesta en práctica de nociones de geometría descriptiva, alzado y planta. Posteriormente y ya en pleno siglo XIX, la noción de dibujo abarcó el "apunte" y el "croquis" sobre todo empleado por artistas, viajeros y científicos.

4 Edificio concebido como centro para la acunación de la moneda oficial en Chile. Posteriormente, en 1845, el inmueble comenzó a ser utilizado como sede del gobierno central, tal como hasta el día de hoy.

5 Emplearé aquí este concepto, sin embargo hago esta investigación permanentes referencias a su significado según el siglo en el que es aplicado. 
Los más destacados fueron Alexander von Humboldt, naturalista y geógrafo alemán quien residió en Chile en 1799, realizó planos, trazados y apuntes de su viaje; Claudio Gay, quien seguiría la tradición en el siglo siguiente con paisajes de Chile e ilustraciones de escenas costumbristas ${ }^{6}$; y Manuel Antonio Matta, con dibujos de escenas del campo chileno. En ese mismo siglo XIX, las contribuciones del siglo anterior se reflejaron en la obra de ilustración entomológica y botánica de Rodulfo Amando Phillipi.

Las ideas de la Ilustración generaron cambios en las prácticas en las Bellas Artes: aparte de lo ya señalado sobre la pintura quiteña y cuzqueña cabe decir que éstas eran las normalmente aceptadas como códigos de representación en Chile, y su transformación hacia un estilo menos religioso y más masivo y republicano ocurrió a finales del siglo que estudiamos y los primeros 20 años del siguiente, tal como se dijo, bajo la influencia de José Gil de Castro.

6 Me refiero al ya mencionado Atlas de la historia física y política de Chile. Ed. Thunot. 1854, conocido también como el Atlas de Gay. 


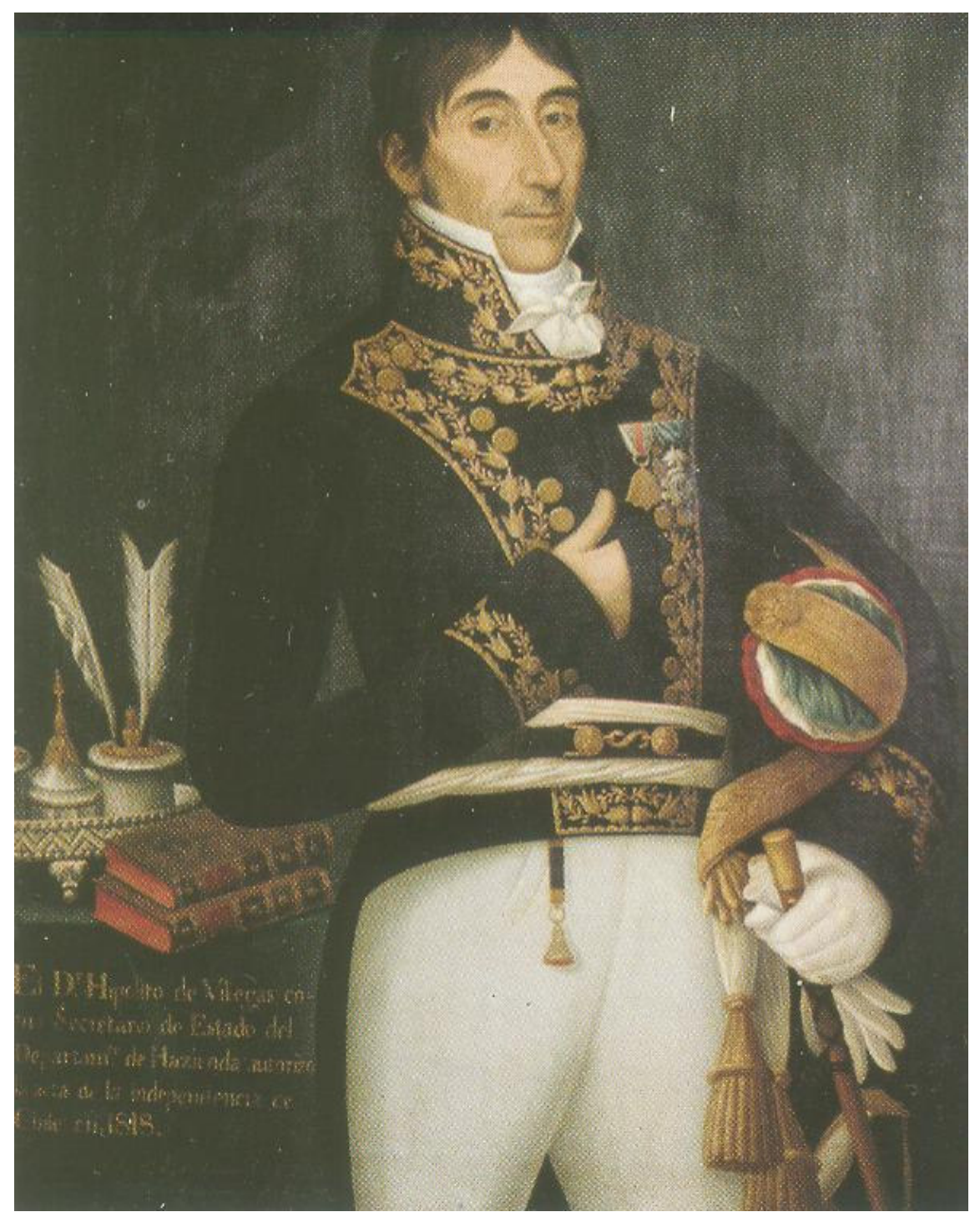

Lámina $\mathrm{N}^{\circ} 13$

Retrato del Dr. Hipólito de Villegas y Fernández. José Gil de Castro. 1822. (Del catálogo José Gil de Castro en Chile. Museo Nacional de Bellas Artes de Chile) 
Los cambios más radicales y el aumento de la masa de artistas activos se vieron reflejados más nítidamente en el siglo XIX. Debo mencionar aquí a Charles Wood, pintor inglés que llegó a Chile en 1819 y que desarrolló parte de su obra centrado en el paisaje y que marcó en gran medida el trabajo formal de la pintura narrativa e histórica que se desarrolló después en Chile durante la segunda parte del siglo XIX. Aunque no hay documentos serios al respecto, se dice que realizó clases como profesor de dibujo en el Instituto Nacional.

Pero llegados a este punto las discusiones son más complejas. La literatura y los documentos de época nos permiten cruzar interpretaciones acerca de las influencias estilísticas que recibió Chile en el siglo XVIII. Dichas interpretaciones no están exentas de visiones políticas acerca de lo que era o no era nuestro país y la manera en que hemos interpretado el desarrollo de nuestra historia. Romanticismo, Neoclasicismo y Barroco son en todo caso, las tendencias que directa e indirectamente se asomaron por Chile en esa época.

Revisemos una idea, que habitualmente ha circulado en Chile en el ámbito de las Bellas Artes:

“...ni la propia Academia de San Luis, fue capaz de retener y adecuar la tradición colonial con las nuevas concepciones. Profesores eminentes como Toesca, De Petris (sic) y Cavallero, incorporan la teoría neoclásica en el dibujo que respondía a las exigencias vigentes en Europa sin vislumbrar la originalidad del continente y de un país que se había nutrido de fuentes propias que no podían extinguirse repentinamente. Tan intensa fue la irrupción del mundo cultural europeo que 


$$
\begin{aligned}
& \text { sus valores se trasformaron en un } \\
& \text { imperativo". } 7
\end{aligned}
$$

A mi juicio, aseveraciones como ésta tergiversan la noción de desarrollo que existía en la Colonia. De hecho, la actuación de Manuel de $\operatorname{Salas}^{8}$ como creador de una academia que incorpora un primer curso de dibujo en Chile, es ya una contribución moderna que no fue capaz de hacerse por mano del gobierno central colonial. Tampoco podemos decir que la contribución de Toesca o de Petri podría considerarse como propiamente neoclásicas. Como se ha dicho en páginas anteriores, Guarda ya sostiene que no pasan de ser barrocas, por la formación de Toesca en la escuela del arquitecto barroco Francesco Sabatini, lo que puede comprobarse en la estructura de los frontispicios de sus obras.

Por otra parte, no es concebible que la cultura chilena se haya podido nutrir entonces de fuentes propias, ya que éstas, si bien existían eran simplemente invisibles en los estratos de poder y para la intelectualidad de la época. La idea de "fuentes propias" es por lo menos ingenua, ya que al parecer se basa en una concepción de originalidad cultural centrada en las manifestaciones de nuestros pueblos originarios. No obstante, no hay pruebas de que dichas manifestaciones fueran conocidas e incorporadas en la producción de la época; por lo mismo no podemos decir que hayan servido de nutriente en el desarrollo cultural y (o) visual de este sector del continente sudamericano. Por lo demás, en los años que nos interesa investigar, pueblos originarios como los huilliches, pehuenches y mapuches, fueron

7 G. Galaz y M. Ivelic, Historia de la Pintura en Chile (Valparaíso, Ediciones de la Universidad Católica de Valparaíso. 1999), pág. 40. Este texto ha sido referencia recurrente en artículos e investigaciones recientes.

8 Como ya he señalado, en esta tesis me referiré extensamente a Manuel de Salas, como un protagonista clave en el desarrollo de la enseñanza del dibujo en Chile 
dominados y algunos de ellos posteriormente sometidos a la "caza" hasta el exterminio, como el caso de los Selk'nam hacia 1885, bajo el pretexto primero de ejercer el control central sobre el territorio conquistado y luego bajo la idea de una incorporación a la naciente república. Desde la perspectiva actual, para dichos pueblos originarios, aquella acción militar, administrativa y financiera, no pasó de ser una forma de sometimiento a la explotación, el esclavismo y la posterior formación de una capa trabajadora entendida como "mano de obra barata" desde fines de la colonia y luego en tiempos de la república, situación que se ha mantenido -lamentablementehasta el siglo XXI.

Si observamos los hechos y revisamos documentos de la época, podemos constatar que en general, la irrupción de la Ilustración europea en el nuevo mundo resultó un imperativo, asumido de formas diferentes y en momentos distintos en toda América del Sur y del cual se advierten señales en los últimos veinte años del siglo XVIII. Me refiero puntualmente a los memoriales que se dirigen al rey, a las actas del Tribunal del Consulado y a los variados intentos por cambiar los códigos de comercio o las reglamentaciones sobre enseñanza a los "naturales" (indígenas). Sin embargo, y a partir de lo expuesto anteriormente al describir los aspectos culturales de América hacia el siglo que estudiamos (ver II.4.2), podemos determinar hoy algunos asuntos relevantes asociados puntualmente al mundo de las Bellas Artes. Destacamos tres:

Lo primero: debemos separar el desarrollo de las ideas en circulación de la práctica artística de la época. Si bien circulaban ideas neoclásicas en un mundo que giraba hacia la Ilustración, no es menos cierto que las nuevas ideas no podían llevarse a la práctica de manera inmediata, puesto que una separación violenta de las ideas de la Iglesia (en cuanto a los temas de la pintura, y al vínculo existente entre artistas e 
Iglesia) podía considerarse un atentando al sistema dominante. Al respecto recordemos el incidente del destierro de los intelectuales chilenos a la Isla Juan Fernández ${ }^{9}$ el 9 de noviembre de 1814, por atentar contra las ideas de la corona, en el momento de la descomposición del gobierno realista.

Lo segundo: El ya mencionado Manuel de Salas fundador de la Academia de San Luis en Santiago, bien pudo importar su modelo de academia y, al interior de ésta, los modelos de trabajo en dibujo, geometría y otras disciplinas, de la academia de pintura y dibujo creada en Perú por José del Pozo en 1791, que ya aplicaba modelos de trabajo que orientaban la práctica del arte hacia una producción secular. No olvidemos que Del Pozo visita Chile en 1794 y bien pudo traer consigo muchas ideas ya puestas en práctica en Perú.

9 Juan Fernández es el nombre del archipiélago chileno ubicado en el Océano Pacífico a 670 kms. de Valparaíso. Está conformado por la Isla Robinson Crusoe, denominada hasta 1966 como Más a Tierra, y la Isla Alejandro Selkirk (antiguamente denominada Más Afuera). La Cueva de los Patriotas (declarada monumento nacional), en la primera isla mencionada, alojó a los deportados por el gobierno español, acusados de instigadores del levantamiento contra la corona. Según el relato de Manuel de Salas, fueron detenidos por Juan Goyena a las 21 horas del 9 de noviembre de 1814. El relato es el siguiente: "Fuimos de navegación los siguientes, llevados al puerto (desde Valparaíso) en tres partidas: Don Ignacio de la Carrera; Francisco de la Lastra; Javier Videla; Juan Egaña; Juan Miguel Benavente; Gaspar Ruiz; Manuel Valdivieso Larraín; Santiago Muñoz Bezanilla; Mateo Arnaldo Hével. Segundo día: José Santiago Portales; Pedro Prado Jaraquemada; Ramón Arís; Ignacio Torres; Juan Crisóstomo Alamos; Carlos Correa de Saa; Francisco de la Sota; Agustín Eyzaguirre; Diego Lavaqui; Remigio Blanco. Tercer día: José Ignacio Cienfuegos; Juan Antonio Ovalle; Diego Larraín; Jerónimo Reinoso; Isidoro Errázuriz; Agustín Vial; Manuel de Salas; Pedro Nolasco Valdés; José María Argomedo; Juan José Echeverría; Baltasar Ureta; Francisco Echagüe; José Antonio Rojas". Cfr. Salas Lavaqui, Manuel., Escritos de Don Manuel de Salas relativos a él y su Familia. Tomo II. p.53

Otros detenidos que llegaron después a la isla fueron: el cura José Castillo; Juan Enrique Rosales; Manuel Blanco Encalada; Enrique Lasalle; Joaquín Larraín y Juan Rafael Bascuñán. Es preciso señalar que muchos de los nombres aquí registrados fueron grandes figuras en la construcción de la República de Chile. 
Lo tercero: La discusión de si la orientación estética de la pintura de fines del 1700 en Chile era barroca o neoclásica, no depende de lo que se producía como resultado en obras, sino de las ideas que subyacían a las iniciativas emprendidas en esa época a la luz de los acontecimientos políticos. Finalmente, sólo resulta un aporte de interés conocer con certeza la orientación estética del período, si lo que observamos como medular son las causas que dan origen a dichas orientaciones, asunto que resulta crucial a la hora de comprender cabalmente las causas del desarrollo de ideas, escuelas y disciplinas en el ámbito de las Bellas Artes. 



\section{ESTADO DE LA ENSEÑANZA EN GENERAL Y DEL DIBUJO EN PARTICULAR, EN CHILE HACIA FINES DEL SIGLO XVIII}

\section{IV.1. Rol de la Iglesia}

Sabemos que la Iglesia en Chile tuvo gran peso en la construcción de la sociedad y el estado. Junto con los primeros españoles, llegaron a Chile las primeras misiones evangelizadoras: los mercedarios, en 1549; los jesuitas, procedentes de Argentina, quienes se establecieron en Chile en octubre de 1553; los dominicos, que se instalaron en Chile cuatro años más tarde; y los agustinos, en 1595. Las órdenes se establecieron primero en la ciudad de Santiago y posteriormente expandieron sus posesiones hasta Chiloé por el sur, en la misma medida que los colonizadores militares trataban de controlar las vías de acceso de las naves hacia el Océano Pacífico. Tal como ya he señalado ${ }^{10}$ la unión entre conquistadores e Iglesia fue sumamente estratégica en el rol de "pacificación" de los pueblos indígenas en la zona sur de Chile. En este juego de conveniencias, la enseñanza jugó un papel relevante. Las órdenes religiosas formaron extensas redes sociales que, cercanas al poder y la aristocracia, lograron sostener la influencia política en la colonia por muchos años. Su rol social fue relevante. A falta de un sistema administrativo más ordenado y poderoso, la Iglesia conformó los primeros registros de civiles, con actas de nacimiento, bautizos, defunciones y matrimonios, hecho común y corriente por más de 300 años en toda América.

El distanciamiento pleno entre el estado y la Iglesia se produce en Chile recién hacia mediados del siglo XIX como resultado de

10 Ver I.6.1. en el presente documento. 
la secularización del proceso político gestada hacia fines del siglo XVIII ${ }^{11}$.

Los procesos de enseñanza en tanto, y por que no decirlo ahora, los procesos masivos en torno a la educación, que había comenzado en Chile justamente con la llegada de las órdenes religiosas, inició un proceso de independencia, al crearse los primeros cursos para estudiantes primarios por iniciativa de particulares o bien directamente vinculados a la corona ${ }^{12}$.

Ya decía líneas atrás que la influencia de la Iglesia en el desarrollo de la vida cultural, artística específicamente, en nuestro país, fue preponderante por más de 200 años. Educadores como Amanda Labarca, e historiadores como Gabriel Guarda, los hermanos Miguel Luis y Gregorio Amunátegui y Toribio Medina, así como otros historiadores contemporáneos de distinta ideología como Pinto, Villalobos o Vitale $^{13}$, concuerdan en señalar que la Iglesia ha sido la institución que por dos siglos ejerció la orientación -cuando no la administración- de la cultura nacional, con diferentes intensidades. Un rol preponderante les correspondió en particular a los Jesuitas.

La autorización de la corona de España, en 1664, para que un tercio de los integrantes de cada expedición a estas nuevas tierras pudieran ser extranjeros, fue dada por permanente en la

\footnotetext{
11 Recién hacia 1840 se prohíbe -por ejemplo- el entierro en las iglesias y sólo hacia esa misma fecha se crea la primera necrópolis estatal en Chile, el Cementerio General de corte laico, desvinculado de la Iglesia.

12 El Archivo Nacional en Santiago registra a tres maestros que mantenían escuelas básicas privadas entre 1768 y 1794: José Luis de Rebolledo, Julián del Rosario y Saturnino Peña.

13 Los nombrados son todos historiadores chilenos con visiones ideológicas de distinto tipo y que, por lo mismo, generan versiones algo diferentes de nuestra historia, con interpretaciones diversas de causas y efectos de los hechos.
} 
real cédula de 1743. Este hecho generó un extraño fenómeno: el ejercicio de las artesanías funcionales, fundamentales para la vida de la colonia, y la formación de los Maestros Mayores, destacados técnicos y artesanos disponibles para las autoridades en la construcción de inmuebles oficiales, infraestructura urbana y mueblería, que hasta entonces era realizada por parte de españoles y criollos, pasó a ser en gran medida ejercicio de sacerdotes bávaros, como consecuencia de la autorización antes mencionada. La venida de jesuitas bávaros a Chile no se detuvo sino hasta la expulsión de la orden, que ya se ha mencionado repetidas veces en este texto.

La influencia -que hoy podríamos denominar como "alemana"se ejerció principalmente desde las áreas de la artesanía, la enseñanza y el culto ${ }^{14}$.

Los archivos catedralicios, los archivos históricos de las órdenes religiosas y los documentos del Archivo Nacional de Chile dan cuenta de este notorio cambio. En efecto, la llegada a Chile de Juan Bitterich (1675-1720) escultor, arquitecto y tallador que junto a su colega Jacobo Kellner marcaron el inicio de la preponderancia jesuítica en el campo de la artesanía y las Bellas Artes aportando una clara influencia del barroco bávaro.

Sabemos que la Iglesia asumió la preocupación por la enseñanza ya desde la llegada de los españoles a estas tierras. Quien fuera

\footnotetext{
14 No está de más señalar la importancia de las artesanías en el desarrollo de la vida en la Colonia: desde los fundidores para campanas, los herreros, los carpinteros, carroceros, sastres, sombrereros y ebanistas hasta los forjadores, trazadores, talabarteros, tejedores y barberos tenían un estatus distinguido entre las clases sociales. Hacia fines del siglo XVII en Santiago de Chile, el Cabildo ejercía control sobre el ejercicio de estas actividades agrupadas en gremios. Los gremios sólo permitían el ingreso de Maestros Mayores, quienes para acceder al ejercicio de su actividad debían dar exámenes ante el Procurador General de la Ciudad y un "fiel ejecutor" (Archivo Nacional. Contaduría Mayor, vol. 700).
} 
Obispo de Santiago, Rodrigo González Marmolejo, ya dictaba clases a la llegada de Pedro de Valdivia hacia el 1500, las que junto a las cuatro operaciones aritméticas y la escritura incluían, como era de suponerse, instrucción católica. En los siglos XVII y XVIII la importancia del Convictorio Carolino, el Colegio Máximo de San Miguel (a cargo de los Mercedarios luego de la expulsión de los Jesuitas) y otros colegios de primeras letras, resulta fundamental para entender la historia de la educación en Chile, pero la escasa literatura sobre estas instituciones no permite conocer mucho acerca del establecimiento de cursos de arte y dibujo en particular.

\section{IV.2. Actuación de los gobiernos en la enseñanza}

El período que nos interesa podríamos definirlo como del fin de la colonia. Este hecho está marcado, como ya se dijo, por una lenta secularización de las instituciones de enseñanza; por lo mismo, ya se observan algunos pequeños centros de enseñanza primaria en manos de particulares pero por sobre todo comienzan a observarse signos de un tardío protagonismo de la corona por asumir el rol de la enseñanza. Este proceso se vio intensificado por la expulsión de los jesuitas en 1767.

Entre 1768 y 1800 se cuentan en Santiago cinco colegios privados, que son las primeras instituciones que lucraron con la educación, ya que cobraban algunos reales a las familias por la enseñanza de los hijos. Las parroquias hacen lo suyo y los datos registran escuelas primarias en las parroquias de San Lázaro, Santa Ana y San Isidro. Estas escuelas enseñan, casi sin distinción, escritura y las cuatro operaciones matemáticas. Hacia el 1800, debido a la abundancia de escuelas primarias se crea incluso un administrador visitador de los colegios a cargo de un 
denominado "Oidor de la Audiencia" 15 . Este crecimiento es un fenómeno generalizado en el país y ocurre particularmente en las principales ciudades de Chile; se registran más de 20 escuelas entre La Serena y Valdivia. Guarda hace una interesante observación acerca de la existencia de estas escuelas: si bien antes de la Independencia se registra este fenómeno expansivo en el número de establecimientos privados y de Iglesia, el número decae considerablemente después de instaurada la República ${ }^{16}$. Para comprender el fenómeno hay que situarse en la fecha concreta y observar que Chile vivió un estado de crisis política y administrativa permanente entre el fin del gobierno realista, constitución de la primera Junta Nacional de Gobierno y la constitución oficial y definitiva del Congreso Nacional ${ }^{17}$. En ese período, muchas de las instituciones coloniales siguieron operando, tal fue el caso del "Oidor de la Audiencia" que dependía primero de la institucionalidad realista (Real Audiencia) y luego lo hizo de la Junta de Gobierno, tal vez debido a que era un organismo regulador de la función de las instituciones responsables de la enseñanza pública y privada.

Cualquier intento por organizar el proceso de enseñanza básica significaba determinar la lengua de instrucción (latín o español), el nivel básico de conocimientos en letras y ciencias (incluyendo matemáticas) y la entrega de las clases de religión, asunto este último que comenzó a dejarse de lado hacia el siglo XIX. Manuel Irigoyen, asesor de la Real Audiencia en materia de escuelas y enseñanza, elabora una Instrucción, a modo de

15 Se trata de un funcionario de la Real Audiencia que ejercía las funciones que hoy realiza un inspector o superintendente.

16 Guarda, Op. Cit. p. 217.

17 En total 13 años, en los que el país tuvo que enfrentar 3 directores supremos, dos de ellos francamente dictadores (Carrera y B. O’Higgins), una invasión española (dirigida por Osorio) en el contexto de una guerra y varias convulsiones internas producto de la discusión por la forma en que se establecía el poder y la administración post colonial. 
compendio de normas básicas que el "Oidor de la Audiencia y Protector de las Escuelas" debía hacer cumplir. En el documento, se establecen normas comunes para las escuelas, principalmente en relación con la asistencia, las materias y los horarios. Es lo que podríamos interpretar hoy como un primer indicio -aunque algo tardío- de la intención del gobierno realista por ordenar el sistema de enseñanza, y un espacio que la administración colonial construye para acceder al control de esta actividad.

Es preciso señalar tres importantes instituciones de enseñanza ${ }^{18}$, que en 1776 ejercieron un rol fundamental en la constitución del sistema de la enseñanza básica o primaria, sin contar las iniciativas privadas de primeras letras, que ya existían ${ }^{19}$.

El primero se denominó Colegio de Naturales de Chillán, eufemismo para señalar una forma de adoctrinamiento y la aplicación de una política de "pacificación" - como ya se dijoestablecida hacia los pueblos originarios en el sur del país. Al de la ciudad de Chillán le siguió uno en Santiago, pero ambos -en manos de la orden franciscana- resultaron un gran fracaso. Labarca $^{20}$ señala que hacia 1790 , el colegio registraba sólo 11 alumnos en sus aulas.

El segundo es la Escuela Anexa al Colegio Máximo de San Miguel. El Colegio Máximo, que había sido fundado en el siglo

18 Cabe señalar que los tres establecimientos educacionales quedaban situados en calles muy próximas, debido a que los solares que originalmente les habían donado a los jesuitas hacia el siglo XVII pertenecían a las mismas familias. Particularmente el convictorio San Francisco Javier ocupaba el sitio donde hoy se levanta el Palacio de la Moneda, en Santiago de Chile, actual sede del gobierno de Chile.

19 Guarda G., señala que en 1794, por iniciativa propia, el particular Manuel Antonio Talavera crea una pequeña aula privada de filosofía de nivel universitario.

20 Labarca, Op. Cit, p.52 
XVII, había conseguido en 1625 el estatus de universidad, pese a que nunca operó como tal; también fue intervenido como parte de los bienes incautados a los jesuitas, razón por la cual el gobierno tenía tuición indirecta sobre las actividades, tanto del Colegio Máximo como de su Escuela Anexa.

El tercero es el Colegio ${ }^{21}$ San Francisco Javier o Convictorio San Francisco Javier, denominado antes Colegio San Pablo, mientras estuvo bajo la tuición de la orden jesuita. A cargo luego de los mercedarios, resultó tan depreciado en su calidad, que en 1777 un decreto real lo interviene ubicándolo como dependiente o anexo a la Real Universidad de San Felipe. Se le cambia de nombre, denominándolo oficialmente Real Seminario de Nobles de San Carlos, pero fue conocido como Colegio San Carlos y luego como Convictorio Carolino, en homenaje al rey Carlos III.

Los cambios generados en esta institución constituyen una fuerte señal de poder y dominio español sobre el sistema de enseñanza. No obstante, los hechos de los siguientes veinte años indicarán que ya era demasiado tarde para un control absoluto de la administración y de los contenidos de la educación en general y de la enseñanza en particular. De los tres, sólo este último -el Convictorio Carolino- logró ser más poderoso y sólido en cuanto a la calidad de su administración y la docencia. Este establecimiento enseñaba en tres años, lenguas modernas, literatura, historia, ciencias y matemática. Luego de su reforma, el Convictorio sólo abrió sus puertas a los primeros alumnos el 10 de abril de 1778. Su reapertura dificultosa se debió a la gran cantidad de problemas administrativos implicados en la

21 Frontaura, en su Historia del Convictorio Carolino, nos entrega una pertinente aclaración acerca de la palabra "colegio", puesto que en su significado actual en Chile es sinónimo de escuela; sin embargo los jesuitas denominaban así a sus residencias y conventos. Cfr. Frontarura y Arana, José M., Historia del Convictorio Carolino. Santiago de Chile, Imprenta Nacional. 1889. 82 pp. 
reparación del inmueble primero y en su reubicación definitiva después.

Los hechos acaecidos en Chile en 1810 (ver línea del tiempo en el capítulo II.1) y que generaron, por decisión de la aristocracia santiaguina, la autonomización administrativa de la capitanía mediante la constitución de la primera Junta de Gobierno independiente de España, tuvieron un impacto inmediato en la forma en que el nuevo gobierno, ya sin un representante del rey a la cabeza, pensaba instalar la ideología (Ilustración) del nuevo régimen.

En febrero de 1811, el director de la Academia de San Luis ${ }^{22}$, Manuel de Salas, envía una nota al gobierno central proponiendo que la academia que él dirige, más la Universidad de San Felipe, el Convictorio Carolino, y el Colegio de Naturales de Chillán (ya muy decaído y con una sede muy pobre en Santiago), formaran un nuevo núcleo más poderoso y laico destinado a la enseñanza formal con directa dependencia de la administración central (es decir, cabildo y tribunales).

Las contradicciones de un período de transición son evidentes hasta en la forma en que se denominan las instituciones. El Congreso del Reino ${ }^{23}$ acogió la propuesta y las consideraciones positivas formuladas por Manuel de Salas, en ese momento síndico del Tribunal del Consulado y el Tribunal de Minería. El acta del Congreso del Reino se firmó dando origen al Instituto

22 A la Academia de San Luis y a la figura de Manuel de Salas me referiré extensamente en las páginas siguientes.

23 Pese a haberse celebrado en 1810 una convocatoria que decidió la independencia de Chile del reino de España, dicha decisión sólo fue en términos administrativos, ya que en la declaración aún se menciona la obediencia al rey. De ahí que debemos decir aún "Congreso del Reino" y no Congreso Nacional o Congreso de la República. Recordemos además el caos administrativo que se vivió en la época, producto de la guerra contra España por la causa de la independencia. 
$\mathrm{Nacional}^{24}$, la entidad educacional de enseñanza básica y secundaria más antigua actualmente en funcionamiento en Chile.

El Instituto abre sus puertas ${ }^{25}$ el 10 de agosto de 1813, en las salas de la Universidad de San Felipe. El diario de la época publicó el decreto del presidente (Director Supremo), que decía $^{26}$ : (Por la importancia del texto, mantengo la forma de escritura del original)

Santiago, Enero 12 de 1813

Los cuidados que incesantemente ocupan al Gobierno no han bastado á distraer su atencion del objeto que debe influir mas segura i directamente en el bien público, cuya prosperidad pende de la formacion de Ciudadanos ilustrados, $i$ nutridos en los principios de virtudes que inspira la buena educacion. á ese fin ha reedificado el antiguo Colegio de S. Carlos i unido á él la Academia de matematicas, el Seminario de Indios, $i$ las aulas de primeras letras, $i$ latinidad, para que todos los jovenes de la capital $i$ de las provincias, que quieran recibir enseñanza, ó en calidad de alumnos, ó de solo concurrentes, oygan lecciones desde los rudimentos de la religion, $i$ el alfabeto, hasta la conclusion de las ciencias

24 A esta institución me dedicaré más extensamente en VII.1.

25 En el emplazamiento actual del teatro Municipal de Santiago, calles Agustinas y San Antonio, en pleno centro de la capital chilena.

26 Periódico La Aurora de Chile, Santiago de Chile, jueves 14 de enero de 1813, tomo 2, № 2, p. 1. 
abstractas, $i$ las de demostracion. El dia 3 de Marzo proximo se abrirá; $i$ para entonces se habran presentado los que aspiran á aprovecharse de las luces que alli se ministrarán; y los Gobernadores, Jueces, Parrocos y Prelados, que faciliten el acceso á los que por la distancia, falta de resolucion, ó de medios para venir, están expuestos á malograr talentos, ó aplicacion, que cultivados pueden ser utiles á la Patria, le harán el mayor servicio facilitandole los arbitrios de aprovecharse de la Doctrina, que se les preparara: en la inteligencia de que no los retraherá ni el luxo, ni las preferencias, que solo se dispensaran al merito i á los Indios, para reparar la dura humillacion á que los redujo la injusticia. Para que llegue á noticia de todo el Reyno, imprimase.

[firmado] Carrera - Portales

Hago notar que la Academia de San Luis era denominada en esta nota solamente como academia de matemáticas (el curso de dibujo había cerrado 15 años atrás). También salta a la vista el carácter selectivo del Instituto, ya que se accedía por sistema de selección, no obstante al haber integrado en su estructura al Colegio de Naturales denominado aquí Seminario de Indios, parte de la población indígena joven podía acceder. 


\section{IV.3. La enseñanza del dibujo en Chile en el siglo XVIII}

Llama la atención que según el censo del Cabildo de Santiago hacia 1614 en la Capitanía no se encuentra ningún dibujante ni trazador; sin embargo encontramos láminas con planos de iglesias, ejecutados directamente por la infinidad de artesanos que sí figuran en dicho censo, tales como albañiles, alfareros, forjadores, cordeleros, fundidores, herreros y zapateros. Esto hace pensar que la práctica del dibujo era una actividad no reglada y no considerada como parte de un oficio gremial, hecho gravitante para la decisión que se toma después, para crear un primer curso de dibujo. No obstante, es posible encontrar dibujos y mapas de quien creo es el primer dibujante, extranjero pero avecindado en Chile, hacia fines del siglo XVI. Se trata del fraile Diego de Ocaña ${ }^{27}$, perteneciente a la orden de Guadalupe, quien en 1599 ingresa a Chile por Perú para difundir el culto a la Virgen ${ }^{28}$. Desgraciadamente, no hay en Chile ningún dibujo de su autoría y hasta donde es posible rastrear, sólo la biblioteca de la Universidad de Oviedo guarda un manuscrito que le pertenece. La literatura indica que las huellas de Ocaña en Sudamérica se pierden en Bolivia luego de su paso por el sur de Chile, donde según algunas cartas, dibuja a los lugareños y establece mapas de la ruta.

Definitivamente no hay indicios del establecimiento de formas de enseñanza artística en Chile sino hasta 1652, momento en que es posible identificar como activos a tres artistas: Francisco de Escobar y Damián Muñoz, ambos pintores, y Crisóstomo Atahualpa, escultor. Los dos primeros ofrecían enseñanza a sus ayudantes, la que se basa fundamentalmente en el desarrollo de tres tipos de pintura, que en esa época eran los sistemas

27 Sabemos de su labor multifacética: fue cronista, dibujante, historiador y dramaturgo. Fue autor de la obra de teatro Comedia de la Virgen de Guadalupe.

28 Pereira Salas, Op. Cit., p. 28 
canónicos de enseñanza: por una parte la pintura de enseñanza fuertemente desarrollada en el $\mathrm{Cuzco}^{29}$ y que consistía en trabajos menores a modo de ejercicios, con influencia flamenca y posteriormente bávara; por otra parte la pintura de retrato muy poco desarrollada; y finalmente la denominada "pintura a la romana", que consistía en obra de pintura con una fuerte base de dibujo elaborada bajo el "modo" del Renacimiento europeo, cuyo eje temático central era el paisaje. Esta tipología persistió hasta el siglo XVIII y en ella se incluyó el dibujo como una base elemental y siempre bajo la idea de "dibujo del natural". En todo caso, estas formas elementales de enseñanza del arte, no constituyeron formas organizadas, ni siquiera próximas a algún modo de enseñanza reglada.

Hacia fines del siglo XVIII no se encuentran vestigios de formas de enseñanza de Bellas Artes en ninguna parte del sistema de enseñanza primaria, secundaria o superior en Chile, salvo el intento de Manuel de Salas de incorporar el curso de dibujo de los maestros Petri y luego Fernández Arrabal, el cual cierra definitivamente el 19 de diciembre de 1799. Este curso operó solamente 16 meses y no será sino hasta la fundación del Instituto Nacional en el siglo siguiente, que los archivos registren el nombre de un tercer profesor de dibujo en Chile ${ }^{30} \mathrm{y}$ con él un sistema ordenado y formal de enseñanza del dibujo. Esta carencia contrasta con los sistemas de enseñanza de pintura y dibujo que operaron en Mojos, Cuzco y Quito a los que ya me he referido antes.

El mismo Manuel de Salas, de gran vocación por el arte, la pintura y el dibujo en particular, no ha dejado testimonio de algún profesor, tutor o guía que lo orientara en sus estudios de pintura y dibujo, impulsados por cuenta propia en 1780. Su

29 Ver II.4.2.

30 Ver luego en VII.1. 
particular sistema -básicamente autodidacta- lo llevó a encargar libros y materiales, y a ejercer desde la experimentación, algunas formas de aprendizaje en materia de Bellas Artes. En cartas de febrero de 1772 y del 25 de enero de 1773, dice a su amigo y cuñado Antonio Rojas:

\section{"Estimaré a $V$. que agregue a mis encargos una flauta buena $i$ algunas estampas, tanto de humo como a buril, por que estoi tomando lecciones de dibujo..." (sic) ${ }^{31}$}

No ha sido posible establecer si efectivamente asistía a clases, tampoco ha sido posible saber con quien tomaba lecciones de dibujo. El intercambio epistolar contenido en el tomo 3 del libro Escritos de don Manuel de Salas y documentos relativos a el su familia $^{32}$ no recoge este importante hecho. Tampoco hay señales o registros en los documentos del Archivo Nacional de Santiago de Chile.

Pero pasemos a revisar los aportes de Manuel de Salas, que cambiarán en Chile el modo de valoración del dibujo y su aplicación. 



\section{MANUEL DE SALAS Y LA ENSEÑANZA DEL DIBUJO}

\section{V.1. Biografía}

Manuel Silverio Antonio de Salas y Corbalán fue hijo de Joseph Perfecto de Salas y los Ríos y de María Josefa Corbalán y Chirinos, nació en Santiago de Chile el 19 de junio de 1754 y murió en la misma ciudad el 28 de noviembre de 1841. Su familia integraba la más alta aristocracia del país; sus antepasados formaron parte de los soldados que operaron en los episodios para el control de la Araucanía hacia el 1600 en el sur de Chile.

Los registros más antiguos mencionan a Domingo García Corbalán, antepasado por la línea materna, con cargos de Mayorazgo primero y secretario de gobierno y guerra después, en tiempos del gobernador Francisco Lazo de la Vega en 1638. El hermano de don Domingo, Antonio, se casó con Magdalena Arias Molina, de quien nació Juan Luis Corbalán Arias, quien en 1721 se casó con Angela Chirinos de Posada (hija de Luis Chirinos y Luisa Lemus Barroso). De esta unión nacieron Clemente, Nicolasa y María Josefa, quien, luego de su matrimonio con Joseph Perfecto de Salas, sería la madre de Manuel de Salas.

De Joseph Perfecto se sabe que, habiendo nacido en Lima, estudió en los colegios de Santo Toribio, San Martín y Colegio Mayor de San Felipe en Lima. Hizo clases en la Universidad de Lima (San Marcos) y fue abogado de la Real Audiencia, ejerciendo la defensa de los imputados por el tribunal de la Santa Inquisición de Lima y de Callao.

Siendo Joseph Perfecto de Salas asesor del Virrey del Perú y luego Oidor de la Audiencia de Contratación en Cádiz (España) en 1776, la familia Salas y Corbalán debió viajar mucho, 
trasladándose de Lima a Santiago de Chile, para luego ir a Madrid, Cádiz y Mendoza en Argentina. Es preciso tener en cuenta que el Virreinato del Perú sólo se dividió dando origen al Virreinato de la Plata (actual Argentina) en 1778 y que no existía entonces la noción de Chile, Perú y Argentina (y otros países de Sudamérica) como repúblicas con fronteras y soberanía claramente establecidas: las fronteras entonces eran un asunto administrativo que permitía relacionar y coordinar los aspectos económicos, políticos y militares del imperio español, bajo distintas administraciones locales. Las distintas comunidades se dividían en intendencias al mando de un Virrey.

Los vínculos de la familia Salas y Corbalán con el poder fueron estrechos desde sus inicios (como familia), sosteniendo como era habitual en esa época una estructura claramente conservadora con predominancia de la masculinidad en cargos de poder y control del grupo como estructura, de ahí que los roles quedaran claramente asignados por masculinidad primero y por edad después.

Los documentos que permiten organizar la biografía de esta familia no revelan protagonismo alguno del conjunto de mujeres del grupo. De la madre, doña María Josefa, sólo sabemos de algunos viajes a Mendoza y que su hijo Manuel la cuidó hasta sus últimos días, como correspondía al hijo mayor. De la hermana María Mercedes poco se sabe. Sus hermanos Judas y José asumieron siempre cargos dejados por Manuel, el hermano mayor.

Cuando su padre fue nombrado asesor del nuevo Virrey del Perú, Manuel viajó a Lima, donde ingresó como alférez voluntario al Regimiento de la Nobleza de esa ciudad el 29 de enero de 1767, en momentos de la guerra de España contra Inglaterra; en 1770 obtuvo el grado de Teniente. El 18 de agosto de 1773 recibe el grado de Capitán de la $8^{a}$ Compañía. En forma 
paralela estudia en la Universidad de San Marcos, en las facultades de Teología y Filosofía, donde se dedica al estudio de la jurisprudencia civil y canónica. Estos estudios no fueron de su pleno agrado, como consta en carta dirigida a quien sería luego su cuñado, el acaudalado minero Antonio Rojas. No obstante, luego de una práctica recibe el título de abogado de la Real Audiencia en Lima. 


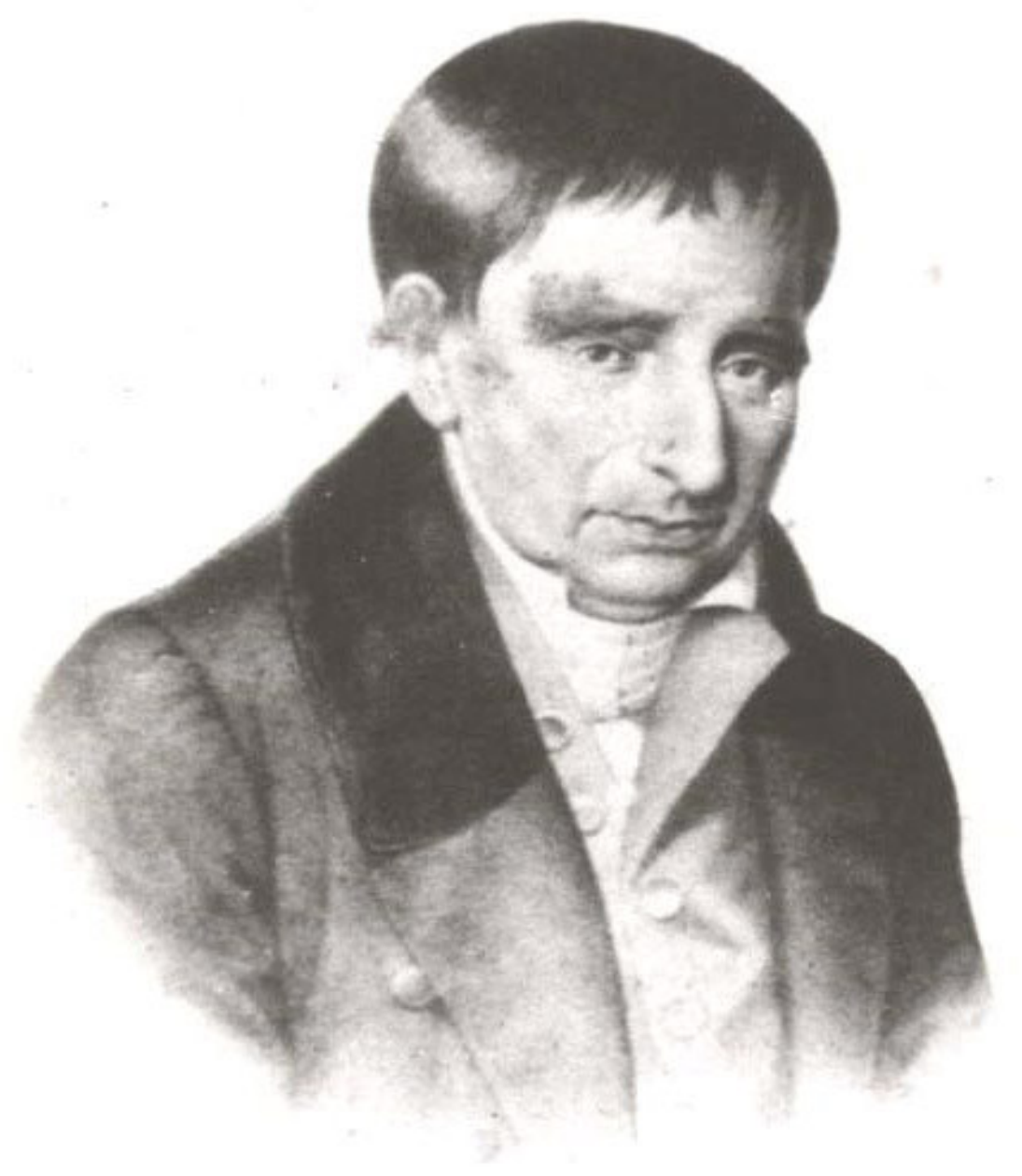

Lámina $\mathrm{N}^{\circ} 14$

Retrato de Manuel Silverio Antonio de Salas y Corbalán. (1754-1841) Dibujo

ejecutado a partir de una pintura actualmente desaparecida. 
Al año siguiente, recibió el cargo de abogado de la Real Audiencia de aquella ciudad. De regreso en Santiago de Chile y a principios de 1775 (enero 1), fue elegido alcalde del Cabildo de Santiago, iniciando así una larga carrera de servicio público que lo llevó a ser Superintendente General de la Población de Indios de La Calera (norte de Chile) bajo el gobierno del general Agustín de Jáuregui, y Procurador General del Cabildo y Abogado de la Real Audiencia de Santiago en 1776. Entre 1777 y 1782, permaneció en España. A su regreso, el Gobernador realista Ambrosio O'Higgins lo designó Superintendente de Obras Públicas, correspondiéndole dirigir la reconstrucción del tajamar del río Mapocho. Como regidor, supervisó la construcción del camino de Santiago a Valparaíso y la reparación del empedrado de las calles de Santiago. También se desempeñó como síndico del Tribunal del Consulado, nombramiento que le había conferido el Rey Carlos IV en 1778. Su preocupación por las cuestiones públicas llevó a Manuel de Salas a ser uno de los más ardorosos promotores de la instalación de la Primera Junta de Gobierno, pese a que antes de este hecho siempre demostró obediencia al Rey y cercanía con los gobernadores coloniales.

El 15 de febrero de 1786 Manuel de Salas se casa con Manuela Fernández Palazuelos, hija del Maestre de Campo Pedro Fernández Palazuelos y de Josefa Aldunate Acevedo. De esa unión nacieron seis hijos: Perfecto, Santiago, Manuel José, Pedro José, Antonia y Manuela.

Aparte de su cargo de Regidor del Cabildo de Santiago, fue Diputado por barrio en 1796 (concretamente del barrio de la Catedral de Santiago con cinco cuadras de jurisdicción), mismo año en que para nuestros efectos tuvo tal vez su más significativa participación en asuntos de enseñanza: la Orden Real del 24 de julio lo autoriza para crear la Escuela de Aritmética, Geometría y Dibujo que él mismo había propuesto 
años antes y que por razones de dinero, el Rey había denegado. El 6 de marzo de 1797 se le designa Director de la Academia de San Luis ${ }^{33}$. No obstante, la Real Orden del 7 de junio de 1802 suprime la Academia de San Luis por clara influencia del Tribunal de Minería que se negaba a apoyar con mil pesos, dicha iniciativa. Aun así, y desobedeciendo esta orden, la Academia continúa su labor. Las constantes apelaciones permiten que se emita finalmente un oficio real en 1806 en el cual de manera explícita se le permite subsistir como escuela. Finalmente De Salas renuncia a ella en el 21 de julio de 1808 a los 54 años.

Por esos mismos años, el Presidente Luis Muñoz de Guzmán le solicita crear el Hospicio de Santiago, lo que implicó la habilitación del antiguo Hospital de la Ollería, iniciativa ésta última que se constata en un documento del 15 de febrero de 1803.

Durante la Patria Vieja, es decir apenas promulgada la independencia de Chile, desempeñó varios cargos políticos: diputado por Itata en el primer Congreso Nacional; secretario de Relaciones Exteriores y miembro del Senado Consultivo.

La fuerte influencia que comenzaron a ejercer en Manuel de Salas las lecturas de Voltaire, Marolois, De Lairesse y Milton, hizo que su acercamiento a la causa de la Independencia fuera más decidida, lo que le significó incluso la prisión y el extrañamiento ${ }^{34}$.

Ya de lleno en la gestión republicana, Manuel de Salas intervino en la promulgación del Reglamento Constitucional de 1812, participó en la redacción del periódico La Aurora de Chile y fue

33 Cargo confirmado en Aranjuez, España, por Real Orden del 31 de enero de 1798.

34 Ver II.5.1 
miembro de la junta que elaboraría el reglamento de prensa. A su pluma se deben importantes documentos como El Diálogo de los Porteros y la Carta al Señor Patricio Español, en los que defendió el derecho de los chilenos a formar un gobierno autónomo. De Salas siempre demostró una profunda preocupación por la enseñanza: fundó -como ya ha dicho- la Academia de San Luis -asunto central en esta investigación- y en la Real Universidad de San Felipe creó la cátedra de Matemáticas. Su obra de mayor significación, y que lo retrata en su dimensión de humanista, fue la Ley de Libertad de Vientres de 1811, que decretó el término de la esclavitud para los hijos de esclavos que nacieran en Chile, desde la fecha de promulgación de dicho cuerpo legal, prohibiendo además el ingreso de nuevos esclavos al país. Posteriormente, en 1823, fue el promotor de la abolición total de esta institución.

A la caída de la Patria Vieja y con la retoma del poder por parte de España, la actividad política que había desarrollado le significó ser confinado por los realistas en el presidio de Juan Fernández, junto a un gran número de otros aristócratas que habían abrazado la causa independentista. Tras la victoria de Chacabuco $^{35}$, todos los confinados fueron repatriados por orden de O'Higgins. Recuperada su libertad, Manuel de Salas continuó ejerciendo una activa vida pública y asumiendo responsabilidades en las áreas tanto de la cultura (educación) como de la política. En 1818, fue nombrado bibliotecario de la Biblioteca Nacional. En 1823, colaboró con la Junta de Gobierno formada tras la abdicación de B. O'Higgins. Ese mismo año, fue electo diputado provincial por Santiago al Congreso Constituyente y presidente del Consejo de Estado. Una de sus últimas actividades públicas se relacionó con la fundación de la Sociedad de Agricultura, a través de la cual se

35 Me refiero a la Batalla de Chacabuco ocurrida el 12 de febrero de 1817, que permite proclamar la independencia militar del reino de España. 
esperaba introducir maquinarias, semillas y nuevas técnicas desarrolladas en Europa, a fin de mejorar la producción agrícola chilena.

La lectura de sus cartas, escritos, representaciones (cartas públicas), memoriales, actas de sesiones del Cabildo y otros documentos, me ha permitido organizar el perfil de un hombre adelantado a su época. Atrapado siempre en el poder del estado, la corona primero y la junta de gobierno después, poseía una verdadera vocación para servir al pueblo, a sus connacionales. Ideales propios de un ilustrado, déspota en un comienzo y revolucionario intelectual después, luego de que cortara sus lazos con el gobierno de España una vez que regresó de su presidio en Juan Fernández.

\section{V.2. Manuel de Salas, influencias políticas y morales: análisis de sus lecturas}

Por las numerosas y elocuentes cartas, reclamaciones, declaraciones, representaciones y memoriales que escribió Manuel de Salas podemos conocer la fundamentación de sus argumentos, los que nos muestran un verdadero ideario por el cual hace transitar su actuación pública desde 1775, fecha en que -a sus 21 años- es designado Superintendente General de la Población de Indios de la Calera y Alcalde Ordinario de Santiago. La carta que dirige a su amigo José Antonio Rojas en febrero de 1772 desde Lima, solicitándole el envío de una serie de libros, ya nos hace saber que De Salas muestra interés por ciertos autores $^{36}$, como se describirá a continuación. El 25 de enero de 1773 , un año después de la primera carta, los libros

36 Se trata de una carta breve donde concretamente menciona al Abate Grecourt, Milton y el libro

El Belisario. 
aún no llegan a sus manos y De Salas repite el encargo, en otra carta esta vez con más detalle.

Dice en este escrito (He respetado la forma de escritura del original):

"Estimaré a $V$. que agregue a mis encargos una flauta buena $i$ algunas estampas, tanto de humo como a buril, por que estoi tomando lecciones de dibujo; i para este mismo efecto envíeme V. a Palomino, 2 tomos; a Samuel Marolois, "De arquitectura y perspectiva”, 2 tomos; a Lebrun, "La Historia de Alejandro" i la de "Don Quijote”, estampadas; a Gerardo Lairesse, "Principios de Dibujo”, un tomo en folio; a Don José de Rivera, alias el españoleto. Añada $V$. a estos autores algunos colores que acá no se hallan, como son, alcorca de grano, carmín superfino de Florencia i azul ultramar. Mis hermanos me dicen le pida a V. "los Viajes de Ciro" en francés $i$ "Mil y un Día”. Para mí envíe V. "El Paraíso Perdido" de Milton; las "Poesías del Abate Grecourt", "El Esprit”, “El Filósofo Sans Souci”, "El Belisario”, y unas "Memorias sobre América y los Americanos", que nuevamente han salido en francés, anónimas en tres tomos (...).Renuevo a V, aunque parezca majadería, todos mis encargos. Me da motivo para esto, la satisfacción que de $V$. tengo i la escasez que hay por acá de todas las cosas, tanto que hasta las putas se han acabado; y así cuando $V$. venga, traiga cien 
cajones de ellas, que tendrán pronta

salida".

Cabe señalar que en la primera carta (de 1772), la palabra "Memorias..." (sobre América) es señalada como "Reflexiones" (sobre América). Sin seguir en orden las solicitudes de De Salas, debo señalar aquí que los datos para rastrear este documento son pobres. Memorias sobre América y los Americanos, en francés, anónimas y en tres tomos, no dice nada acerca del documento que le interesaba a De Salas. La Biblioteca de la Universidad de San Marcos en Lima registra algunos documentos en francés, relacionados con las ideas por las que De Salas demostró interés. Veamos éstos:

a) Journal des Observations Phisiques, Mathemathiques de Amerique Meridionale de Louis Feullée, de 1708.

b) De Amadeo Francisco Frézier Relations du voyage de la mer du sud aux costes du Chili et de Pérou.

c) Carta geográfica de la provincia de Río de la Plata, Tucumán y Paraguay con parte de los continentes de Chile, Perú, Santa Cruz y Brasil de Juan Ramón Koening (16231709). En español, pero supuestamente habría una versión en francés.

d) Noticias secretas de América, de Jorge Juan y Antonio de Ulloa. Texto de la Academia de Ciencias de Paris de 1735, que descarto de plano, ya que sólo fue dado a conocer en 1826.

En síntesis, no es posible identificar con precisión los documentos solicitados

Sobre los otros documentos, Pereira Salas ${ }^{37}$ averigua sobre los autores y deja vagas descripciones sobre forma y contenido de los textos. Señala Pereira que la obra de Palomino solicitada por Manuel de Salas sería El Museo Pictórico y escala Optica, de 
Antonio Palomino y Velasco, editado en España en 1715. En efecto, al parecer es la obra más conocida y difundida de este autor y bien podría resultar el fundamento de una posición acerca de la representación gráfica, como veremos más adelante.

De Arquitectura y perspectiva de Samuel Marolois, Pereira Salas lo identifica efectivamente como Fortificaction ou Architecture militaire, tant offensive que defensive, publicado en Ámsterdam en 1627.

Los Principios de Dibujo de Gérard de Lairesse (1640-1711), tratadista holandés de quien Pereira Salas no logra obtener datos precisos, pero a quien atribuye fuertes influencias del neoclásico. Por último, la carta no explica nada respecto a la solicitud en torno a José de Ribera (Xátiva 1591), alias "El españoleto", por lo que resulta imposible averiguar acerca de un pedido en concreto.

Un análisis más detallado de la bibliografía mencionada en la carta de 1773, nos rebela valiosos antecedentes respecto a esos autores, que permiten comprender la base teórica y las preocupaciones de Manuel de Salas. Iré en el mismo orden que propone De Salas en su carta: Palomino, Marolois, Lebrun, Lairesse, para luego referirme al segundo grupo de autores.

1. Palomino: La carta de Manuel de Salas se refiere concretamente a Acisclo Antonio Palomino de Castro y Velasco (Bujalance $^{38}$ 1653- Madrid 1726), pintor cordobés de la corte de Carlos II. Su obra es considerada hoy clave en la producción de la pintura mural del barroco español, y en ella se destacan particularmente los murales realizados en la Iglesia de los santos Juanes y la Iglesia de San Nicolás (Valencia). En esa misma 
región, más precisamente en Vall d'Uixó deja su última obra, los frescos del ábside de la parroquia del Santo Ángel.

Palomino elaboró además importantes textos de estudio. En este sentido, la obra más conocida de Palomino y a la que con toda seguridad se refiere Manuel de Salas es El museo pictórico y escala óptica, sólo que De Salas al parecer cuando la solicita a su amigo Rojas no conocía el tomo 3, ya que encarga únicamente dos. Sabemos que la primera edición corresponde al tomo 1, de 1715, impreso por Lucas Antonio de Bedmar, impresor del reino. Conocemos además la edición realizada en 1795 en la imprenta Sancha de Madrid.

El tomo I se denomina: El museo pictorico y escala optica: theórica de la pintura, en que se describe su origen, esencia, especies y qualidades y se prueban con demonstraciones matemáticas y filosóficas sus mas radicales fundamentos. El texto está compuesto por tres libros: el aficionado, el curioso y el diligente. En el primero, se entregan definiciones y técnicas de la pintura; se abordan además definiciones sobre luz, simetría, perspectiva y explicaciones acerca de los argumentos (temas) de la pintura y la metáfora. El libro segundo, analiza diferencias entre ciencia y arte y está dedicado a teorizar acerca de la práctica del arte y en particular de la pintura. Realiza además aquí una suerte de taxonomía de las artes. Un asunto particularmente relevante ocurre en el capítulo $\mathrm{X}$ de este segundo libro del tomo 1. En él, Palomino realiza lo que podríamos hoy denominar una revisión bibliográfica de los textos o tratados sobre la pintura, donde incluye sus propias fuentes teóricas. Este capítulo nos entrega una valiosa panorámica de sus lecturas citando 44 textos de claro origen renacentista escritos en italiano, 12 en francés, uno en inglés y uno en flamenco. 
El libro tercero -llamado El diligente- aborda la proyección de los cuerpos, con claro énfasis en la geometría; la proyección de la luz y la proyección del color.

El tomo II se titula: El museo pictorico y escala optica: practica de la pintura, en que se trata del modo de pintar a el olio, temple, fresco, con la resolución de todas las dudas que en su manipulación pueden ocurrir.... Este tomo está compuesto por seis libros, que siguen en su numeración el correlativo en relación al tomo anterior. De esta forma el texto está compuesto por El Principiante (libro IV); El Copiante (libro V); El Aprovechado (libro VI); El Inventor (libro VII); El Práctico (libro VIII); El Perfecto (libro IX), todos referidos secuencialmente a los distintos grados en que divide a los pintores, asunto que se refleja en el título de cada libro. Se incluyen materias como perspectiva práctica, técnicas de la pintura, herramientas y utensilios para pintar, importancia del dibujo en la pintura, simetría del cuerpo humano, anatomía de huesos del cuerpo humano y otros tópicos de ayuda al pintor.

Finalmente, el tomo III se denomina: El museo pictorico y la escala optica. El parnaso pintoresco laureado con las vidas de los pintores, y estatuarios eminentes españoles, que con sus heroycas obras. Este tomo consta de referencias a la vida de 226 pintores y escultores españoles, es posible constatar hoy algunas imprecisiones respecto a estas biografías, asunto que ya es señalado por Salvador Aldana Fernández ${ }^{39}$.

Un libro más antiguo de su autoría es el Indice de los términos privativos de la pintura (Madrid, 1705). Sabemos también que Palomino fue autor de Las ciudades, iglesias y conventos en 
España, donde ay obras de los pintores y estatuarios...españoles puestos en orden alfabético. (Londres, H. Woodfall, 1746).

Palomino cursó filosofía, teología y leyes, y en forma paralela ejerció como pintor de la corte. Muy pronto comparte su carrera de pintor con la de teórico en pintura, emprendiendo una verdadera investigación acerca de las técnicas, así como también el catastro de artistas de 1705. A juzgar por su obra, Palomino poseedor de una base cultural y de conocimientos tal vez similar a los artistas del Renacimiento, poseía una metodología y una lógica investigativa que caracterizaría luego a la Ilustración. La edición de 1795 de El museo pictórico y escala óptica cae justo en el momento en que las ideas de la Ilustración estaban ya en circulación. Fue un pintor que, como pocos en su época, pudo elaborar a inicios del siglo XVIII una teoría de manera racional y sistemática, y más aún hacerla convivir con su desarrollo de obra pictórica. Tanto por el idioma, como por la contundencia del contenido y el carácter "científico" de sus postulados, nos parece sin lugar a dudas que la obra de Palomino ejerció una gran influencia en Manuel de Salas.

A juzgar por los datos que nos entrega De Salas en sus cartas y discursos, la estructura del conocimiento concebida por Palomino calza exactamente en el modelo de pensamiento e ideas que manejaba el propio De Salas; pese a que si lo comparamos con la erudición de un sabio europeo, detectamos en el chileno un precario manejo sobre arte, geometría y matemática. No obstante esta diferencia, las acciones que emprendió De Salas muestran una notable correspondencia con las ideas de Palomino, fundamentalmente por la vinculación entre geometría y dibujo, relación que una vez implementada pasaría a ser un curso de dibujo lineal. La obra de Palomino enseña a su vez, la forma más ordenada de organizar un curso 
general de dibujo y entrega instrucciones de cómo vincular esta disciplina en etapas superiores a la pintura. Tal vez estas lecturas constituyen la base y el origen del más relevante aporte teórico que se haya realizado en Chile en materias asociadas a la enseñanza de las Bellas Artes: el modelo de pensamiento y de trabajo de Antonio Palomino.

\section{EL MUSEO PICTORICO,}

Y ESCA L A Ó TICA.

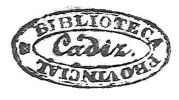

TEÓRICA DE LA PINTURA,

EN QUE SE DESCRIBE

SU ORIGEN, ESENCIA, ESPECIES

Y QUALIDADES, CON TODOS LOS DEMAS ACCIDENTES

QUB LA ENRIQUECEN É ILUSTRAN.

Y SE PRUEBAN CON DEMONSTRACIONES

MATEMATICAS Y FILOSOFICAS SUS MAS RADICALES

FUNDAMENTOS.

POR DON ANTONIO PALOMINO

DE CASTRO Y VELASCO.

TOMO PRIMERO.

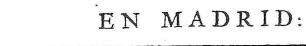

EN LA IMPRENTA DE SANCHA.
ANO DEM DCCXCV.

Se hallará en su Libreria en la Aduana vieja.

Lámina $\mathrm{N}^{\circ} 15$. Portada de Museo Pictórico y Escala Optica, de Palomino, edición de 1795.

Biblioteca de Cádiz. 
2. La obra de Samuel Marolois. Mathematicum opus absolutissimum: continens geometriae, fortificationis, architecturae \& perspectivae theoreticae ac practicae regulas, demonstrationes, \& figuras perfectissimas. Studio atque opera Alberti Girardi; mathematici Cl. Recognitum ac multis notis illustratum, incluye trabajos de Jan Vredeman de Vries y aportaciones de Hendrik Hondius discípulo de Marolois.

Samuel Marolois fue un matemático francés que publicó en los Países Bajos, con la ayuda del editor Janssonius en 1638.

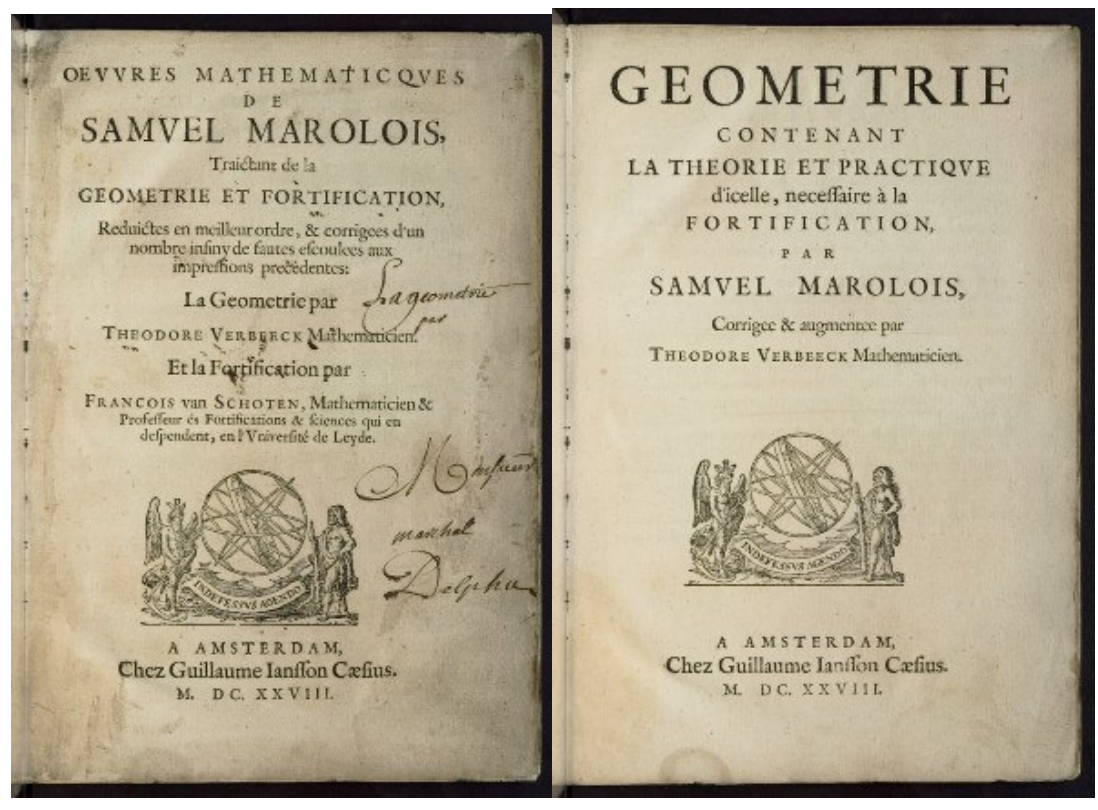

Láminas $\mathrm{N}^{\circ} 16$ y 17

Portadas de dos ediciones de Marolois. El título original de esta obra, tanto para las ediciones en latín como para la francesa, fue realizado en huecograbado por el editor. Sin embargo el título de la portada de la derecha, lleva una enmienda en el lugar donde se indica la fecha, 1638; posteriormente y a mano se corrigió con la fecha "1658". Ambas ediciones son de la misma casa editora. 
Esta edición fue corregida por Albert Girardi, tal como explica el libro en su portadilla. El trabajo de Marolois en esta edición consta de explicaciones sobre las láminas, las que fueron ejecutadas de manera bastante pictórica o "artística" y se refieren a geometría, si bien explican y se aplican a problemas asociados con medidas, proporciones, perspectiva y vistas. Marolois trabajó primero en temas asociados a las fortificaciones (texto publicado en 1615) en lo que resultó ser un libro -ricamente ilustrado- acerca del arte alemán de la fortificación, tal vez el más completo que se haya escrito hacia comienzos del siglo XVII. En todo caso, la aproximación de Marolois al problema en ese libro fue estrictamente de carácter geométrico.

$\mathrm{Su}$ obra, que en francés se denomina Opera mathematica: Oeuvres mathématiques traictans de géométrie, perspective, architecture et fortification fue muy popular y se reimprimió varias veces en el siglo XVII. Al igual que la obra de Palomino, por su erudición y estilo didáctico (podríamos decir además "artístico") puede imaginarse el fuerte impacto que debió de ejercer en las formas de enseñanza y los contenidos de cursos en matemáticas, geometría y dibujo, materias que en este tipo de literatura se encontraban bastante vinculadas. 


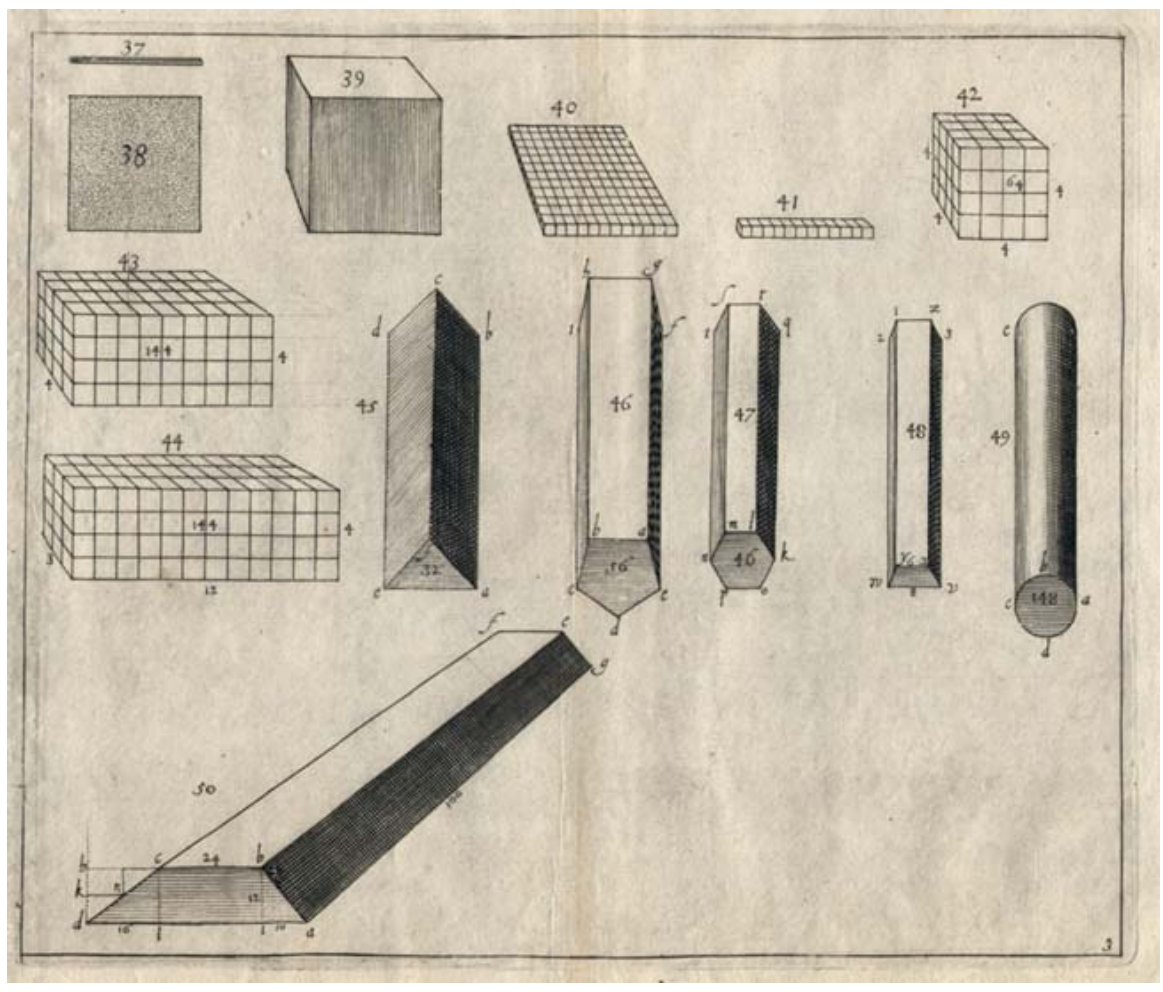

Lámina $\mathrm{N}^{\circ} 18$

Lámina No 3 del libro Geometría, de S. Marolois.

3. Lebrun: La sola frase de De Salas en su carta, solicitando "... a Lebrun, La Historia de Alejandro y de Don Quijote, estampadas...", ha motivado una pequeña investigación bibliográfica para determinar la línea teórica e ideológica de esta literatura. La Biblioteca Nacional de Francia registra 333 autores de apellido Lebrún; en muchos casos se trata del mismo sujeto que queda registrado bajo distintos pseudónimos "Lebrún". Así, tenemos por ejemplo a Lebrun Citoyen y a Antoine Lebrun-Tossa ambos nombres para un mismo autor. La selección que buscó descartar a aquellos que tenían menos de 15 
años al momento de escribirse la carta analizada aquí, ha dejado a 13 personas como posibles autores de la "Historia de Alejandro y de Don Quijote, estampadas...".

De Salas no menciona nada más que el apellido "Lebrun" y sabemos que hay cinco intelectuales de ese nombre que ejercieron a su vez como políticos, filósofos y escritores. He procedido a manejar las coordenadas fecha, país y materia para determinar a este autor, ya que la "Historia de Alejandro y la Historia de Don Quijote, estampadas...", constituye un parámetro muy amplio; los buscadores de biblioteca no arrojan concordancias entre autor y obra. ${ }^{40}$

No obstante, he podido encontrar un libro de menor importancia del autor francés Gilbert du Verdier del cual hay dos versiones.

40 Autores de apellido Lebrun que registra la Biblioteca Nacional de Francia en agosto de 2006 (en orden de fecha de nacimiento):

Lebrun, Charles. (1619-1690). Pintor. No escribió documentos históricos.

Lebrun Desmarettes, Jean-Baptiste (1651-1731). Escritor religioso, autor de obras acerca de la Iglesia en la antigüedad.

Lebrun, Corneille (1652-1727). Grabador. Autor de láminas (grabados) sobre Persia y las Indias orientales.

Lebrun, Pierre (1661-1729). Autor de textos sobre oratoria y liturgia eclesial.

Lebrun, Antoine-Louise (1680-1743). Autor de obras de teatro lírico.

Lebrun, Ponce Denis Écouchard (1729-1807). Poeta, autor de novelas.

Lebrun, Jean-Étienne Écouchard (1738-1765) llamado también Lebrun de Grandville o Lebrun Pindare y Le Pindare Française.

Lebrun Charles-Françoise (1739-1824) Duque de Plaisance. Llamado también Charles Lebrun, Lebrun, Prince Lebrun, Charles Lebrun Plaisance. Hombre de Estado, Cónsul de Bonaparte; autor de novelas históricas. Sería por la temática de sus obras el autor más cercano al mencionado por Manuel de Salas.

Lebrun, J.P.P. (Citoyan Lebrun) (1748-1813). Catálogo de obras a la venta. También denominado Jean Baptiste Pierre Lebrun.

Lebrun, P.A. (Abate) (1749-1840).

Lebrun-Pigault, Charles. (1753-1835). Llamado también Le Brun, Le Brun Pigault y Charles Le Brun-Pigault. 
En efecto, L'histoire entière d'Alexandre Le Grand (Historia completa de Alejandro el Grande) tiene una versión de 1671 (Paris) con 12 láminas y otra de 1697 con grabados (Paris, 744 páginas). Creo que la descripción de la primera se acerca a la del libro que Manuel de Salas encargó, pero tratándose de otro autor no es pertinente ahondar en él. Finalmente, la fuente más confiable y concordante con el libro al que hace referencia Manuel de Salas, se encuentra justamente en El museo pictórico y escala óptica de Antonio Palomino a quien me he referido en páginas anteriores. En el párrafo sexto, del capítulo $\mathrm{X}$ del tomo primero, Palomino dice:

$$
\begin{aligned}
& \text { Monsieur Filibien, escribió sobre las } \\
& \text { pinturas de los triunfos de Alejandro } \\
& \text { Magno, del insigne Monsieur Lebrun; } \\
& \text { (cuyas estampas nos dan claro testimonio } \\
& \text { de la eminencia de sus obras) y además de } \\
& \text { ser este libro de suma elocuencia, incluye } \\
& \text { muy importantes dogmas, para la buena } \\
& \text { economía de la pintura. }{ }^{41}
\end{aligned}
$$

Las últimas líneas obviamente hacen referencia al libro de Filibien.

Se trata entonces con seguridad, del mismo documento al que alude Manuel de Salas y es muy probable que esta referencia provenga de la lectura que Manuel de Salas hizo en su momento de Escala Optica, pues pese a no tener en su biblioteca un ejemplar, es muy probable que haya tenido en sus manos la obra de Palomino durante su estadía en Lima. Por esa causa me parece que las láminas que solicita De Salas sólo pueden corresponder a dos posibles artistas ya conocidos por Palomino

41 El Museo Pictórico y Escala Optica. Palomino, Antonio. Edición facsimilar. Madrid, editorial Aguilar. 1947, p. 260. 
en 1715: Corneille Lebrún o Charles Le Brun de la Academia de Paris.

A juzgar por las ideas de Manuel de Salas y el perfil de Charles Le Brun, cuyo modelo de academia de pintura era sobradamente conocido por los intelectuales chilenos, sumado al hecho que Luis XIV encargó a este pintor una serie de obras sobre las batallas de Alejandro Magno, no puedo más que reconocer que se trata de este pintor francés nacido en 1619, del que seguramente se editaron láminas o estampas en formato de carpetas (folios).

4. Gérard de Lairesse. Pintor, dibujante y grabador valón. Hijo del pintor y decorador Renier de Lairesse y de Catherine Taulier. A la edad de 23 años abandona su ciudad natal -BoisLe-Duc, Lairesse- y se establece en Utrecht; en 1665 se instala definitivamente en Ámsterdam. En aquella época el Principado de Lieja no era un lugar muy tranquilo, ya que se encontraba en el centro de variadas disputas territoriales, en medio de las cuales este Principado luchó por mantenerse independiente. La llegada de la contrarreforma generó una fuente importante de trabajo para los pintores, escultores, dibujantes y grabadores, muchos de los cuales operaron desde diversas ciudades de lo que hoy conocemos como Países Bajos, pero teniendo como principal cliente a la Iglesia. Tal fue el escenario donde Lairesse desarrolló su obra principalmente como dibujante y grabador. 
4,353

\section{GODEFRIDI BIDLOO,}

Medicinæ Doctoris \& Chirurgi,

\section{A N A TOM I A \\ $\begin{array}{lllllllllllllll} & \mathrm{H} & \mathrm{V} & \mathrm{M} & \mathrm{A} & \mathrm{N} & \mathrm{I}\end{array}$ \\ C O R P O R I S,}

Centum \& quinque TA BVLIS,

Per artificiofiff. G. DE L A I RESSE ad virum

delineatis,

D E $\quad M \quad O \quad N \quad S \quad T \quad R$ A $T$ A,

$1, \$ 43$

Veterum Recentiorumque Inventis explicata plurimisque, hactenus non detectis,

$\begin{array}{lllllllllll} & \mathrm{L} & \mathrm{L} & \mathrm{V} & \mathrm{S} & \mathrm{T} & \mathrm{R} & \mathbf{A} & \mathrm{T} & \mathbf{A} \text {. }\end{array}$

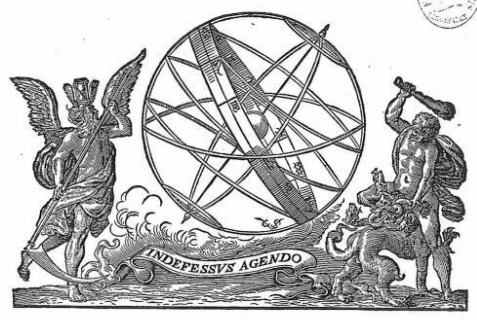

$\triangle M S T E L O D A M I$

Sumptibus Vidux JOANNIS à SOMEREN, Hxredum JOANNIS à DYK HENRICI \& Vidur THEODORI BOOM.

M DC LXXXV.

Lámina $\mathrm{N}^{\circ} 19$

Portada del libro Anatomia Humani Corporis de Bidloo, con ilustraciones de G. de Lairesse. 
De 1685 conocemos las ilustraciones de Anatomia Humani Corporis, con texto de G. Bidloo, en cuyas planchas trabajó además Abraham Blooteling.

Habiendo quedado ciego hacia 1690, De Lairesse publica con la ayuda de sus hijos la obra Grondlegginge der Teekenkunst (1701), que podríamos traducir como Principios fundamentales del arte del dibujo (o del diseño) y que es la obra a la que se refiere Manuel de Salas.

Seis años más tarde, De Lairesse publica el Gran Libro de la Pintura. Muere en Ámsterdam a los 70 años de edad.

La obra que nos interesa-Grondlegginge der Teekenkunst- fue impresa en Amsterdam por G. Wetstein en 1713 (115 páginas) y se trata de un manual para aprender a dibujar. De hecho la versión francesa consultada denuncia el estilo libre, bastante coloquial, en su título Les Principes du dessein, ou Méthode courte et facile pour aprendre cet art en peu de temps (Ámsterdam, 1746; con 23 láminas grabadas), versión que seguramente fue la que conoció De Salas, dado que dice en su carta, refiriéndose a De Lairesse “...un tomo en folio...”, es decir un tomo con láminas en formato de carpeta. Recordemos que cuando Manuel de Salas solicita el texto, estaba en proceso de aprender a dibujar ${ }^{42}$, por lo que un manual bien pudo ser de gran ayuda en su labor autodidacta. La base del texto de De Lairesse se centra en un modelo de aprendizaje por ejercicios de copia, junto a "consejos" del maestro, en este caso el autor. La base teórica de este texto es científica y didácticamente estructurada, muy acorde con la estructura de Manuel de Salas.

42 Vuelvo a lo señalado antes en IV.3. La enseñanza del dibujo en Chile en el siglo XVIII. No hay datos que señalen que sus "lecciones de dibujo", como menciona en su carta a su amigo Rojas, fueran efectivamente dictadas por un profesor, por lo que podemos deducir que su trabajo era una práctica autodidacta. 
5. El Paraíso Perdido de John Milton. No llama la atención el que Manuel de Salas tuviera a Milton entre sus lecturas. El Paraíso Perdido (1667) fue un trabajo heroico según señala Jenaro Talens en la presentación de la última edición bilingüe del poemario (Ed. Galaxia Gutenberg, 2005) ${ }^{43}$. El texto fue escrito estando su autor ciego y perseguido por razones políticas, como consecuencia de la sangrienta lucha desatada cuando los Estuardo retomaron el control del gobierno de Gran Bretaña (Restauración) concluyendo así el protectorado de Cronwell, de quien Milton había sido Secretario de Lenguas Extranjeras.

Recordemos que el gobierno de Cronwell reemplazó temporalmente a la monarquía, aprobando leyes que entre otras cosas hacían posible el divorcio, liberalizaban el comercio y favorecían la navegación mercantil; logró desbaratar el poder español sobre Jamaica. El gobierno del Lord Protector Oliver Cronwell tuvo un marcado acento protestante, anticatólico y puritano. En el poemario aludido (12 sonetos), Milton trata asuntos morales y éticos, como la justicia, la corrupción, la verdad y la fe; no obstante la obra posee la carga ideológica protestante, pero defensora de los valores de la sociedad que el mundo europeo vería hacia fines del siglo siguiente. No puedo dejar de señalar que en 1644, John Milton publica sus reflexiones Sobre la educación en las cuales relaciona los aspectos beneficiosos de la educación aplicados a un ciudadano para el mejoramiento de su país con aspectos propios de la religiosidad (valores y moral), dato no menor a la hora de subrayar las preferencias de autores de Manuel de Salas.

43 Hago referencia a El Paraíso Perdido de J. Milton en su edición más reciente de 2005 (Galaxia

Gutenberg-Círculo de Lectores) debido a que se trata de una obra muy conocida. Resulta intrascendente entonces hacer referencias a ediciones cercanas a M. de Salas o bien a la edición original en inglés de 1667. 
6. Abate Goucourt. Primero, habrá que considerar que Manuel de Salas tiene 19 años en el momento de escribir su pedido bibliográfico al amigo Rojas. En segundo lugar, y a juzgar por el tono coloquial e íntimo de la carta, debo señalar que el muchacho en ese entonces bien podía darse algunas licencias que de adulto, tal vez, ocultó. Subrayo las líneas finales del párrafo de esa carta de 1773:

\begin{abstract}
"Renuevo a $V$, aunque parezca majadería, todos mis encargos. Me da motivo para esto, la satisfacción que de $V$. tengo y la escasez que hay por acá de todas las cosas, tanto que hasta las putas se han acabado; y así cuando $V$. venga, traiga cien cajones de ellas, que tendrán pronta salida"
\end{abstract}

No es un desvío de este trabajo señalar este rasgo distinto de Manuel de Salas. El Abate Goucourt, de quien se solicitan "poesías", resulta ser más precisamente el Abate Jean-Baptiste Willart de Grécourt, poeta francés, efectivamente abate de la Iglesia de Saint Martín de Tours, quien pierde su calidad de cura, al atribuírsele una homosexualidad declarada y la autoría de una fuerte sátira a la Iglesia católica contenida en forma de poesía en el libro Philotanus. En 1796, (cincuenta años después de su muerte) se publica la edición de sus obras completas con muchos grabados y que contiene además textos inéditos como La Mule du Pape, par le chevalier de Saint-Gile que de seguro fue el documento que, en su momento, le costó la expulsión de las filas de la Iglesia. Es, como bibliografía de un joven, un libro prohibido, nada altruista y que considero no tuvo más impacto en De Salas que el descubrir una faceta del mundo licencioso, marginal y proscrito en la sociedad chilena de fines del siglo XVIII. Tal vez por ello, Manuel de Salas se refiere a este autor en un apartado de la larga carta en donde los primeros libros 
solicitados poseen un corte erudito, docto, en tanto el segundo párrafo contiene libros de literatura variada y superficial, como Belisario, las poesías del Abate Grécourt, El filósofo Sans Souci y otros ya mencionados.

7. Belisario. Jean-François Marmontel, autor de Belisario, nace el 11 de julio de 1723 en Bort-les-Orgues (Córreze) y se registra muerto el 31 de diciembre de 1799 en Abloville (Eure). Perteneció a la Academia Francesa desde 1763 y fue además director del periódico El Mercurio de Francia. Autor multifacético, exploró la comedia y el drama elaborando libretos para obras cortas y óperas, fue novelista y poeta. Como libretista para ópera y ballet, puso en boga un cierto tipo de obra sencilla, pero muy popular en París en 1770, de corte histórico, cuando no épico y galante. Zémire y Azor, comedia ballet en cuatro actos cuyo texto le pertenece, por ejemplo, fue estrenada en Francia e Italia en 1771 con bastante éxito. Otra, como Céphale et Procris de André-Ernest-Modeste Grétry es una tragedia lírica; en esta obra, los textos de Marmontel se basaron en otros de Ovidio; posteriormente, al incluírsele danza clásica, la obra fue denominada ballet heroico. Fue estrenada en el Théâtre Royal de Versailles el 30 diciembre 1773, con motivo del matrimonio del Conde de Artois con la princesa MarieThérèse de Savoie.

Los contenidos de la producción de Marmontel ya nos indican que se trata de un escritor de fuerte contenido novelesco histórico. Textos adaptados, historias rescatadas de episodios verdaderos pero distorsionados u otros basados en textos de la antigüedad, fueron la línea de escritura de este autor, que le sirvió para generar una obra liviana de contenido moral. Es este rasgo el que con toda seguridad provocó un fuerte impacto en la intelectualidad de los países de América, en los momentos en que se gestaba la independencia del reino español y las ideas de la Ilustración se comenzaban a instalar en estas latitudes. En 
otras palabras, la narrativa moral de Marmontel subrayó virtudes como la fidelidad, la lealtad, el respeto de los hijos a los padres, la amistad, la honradez, el patriotismo, la felicidad de los individuos, la independencia y el respeto al rol del ciudadano, asuntos de los que se comenzaba a hablar en el Virreinato hacia fines del Siglo XVIII y que obviamente pertenecían a la lógica que impregnó a la Revolución Francesa. No obstante, Marmontel utilizó técnicas recurrentes en su literatura, tales como los finales felices, las reconciliaciones, o las moralejas. Los biógrafos de Marmontel señalan que su obra más exitosa en América fue Bélisaire, que hemos traducido aquí -al igual como lo hizo Manuel de Salas- como Belisario. El libro de 272 páginas publicado en París (París, Merlin) en 1767, es tal vez el documento más representativo de la narrativa moral que hemos descrito. Junto a los otros textos del mismo autor [Les] Incas, ou la Destruction de l'empire du Pérou (París, Lacombre, 1777) y Contes Moraux (Paris, Belin, 1819), fue parte de la biblioteca de los intelectuales de fines del siglo XVIII y principios del siguiente. No obstante, quienes se han dedicado con detención al estudio de la obra de Marmontel en América, señalan que su obra fue muy perseguida por la Inquisición ${ }^{44}$, llegando a ser literatura proscrita en Perú, cuando no en Francia misma El mismo Marmontel sufrió la prisión en La Bastille. La idea de la moralidad narrativa, fue un estilo que circuló profusamente en Inglaterra, de la mano de Samuel Richardson, para luego difundirse como género con las obras de Voltaire (Cándido, 1759) y de Diderot (La religieuse; Contes Moraux y nouvelles idylles, 1773).

Tan fuerte fue el afán de difundir ideas moralistas, que las tramas en la producción de Marmontel -guiones y novelaspodían contener rasgos de incoherencia que sus lectores tal vez

44 Cfr. Nuñez, E. La Narrativa Moral: Marmontel. Lima: Universidad Nacional San Marcos. 1997. 267 pp. 
no detectaron o a los que no les dieron importancia, ya sea por ignorancia o simplemente por la pasión con que consumían aquella producción, tal vez comparable con los guiones de las actuales comedias de televisión. En Incas, ou la Destruction de l'empire du Pérou, Marmontel mezcla en el relato ideas, nombres y culturas tan lejanas como disímiles al referirse a los Incas (Perú) y a los Aztecas (México) en la construcción de la trama de su novela. Este texto, al igual que El Belisario toca asuntos concretos ligados a la Iglesia y a la estructura del estado francés de la época. Eran estas novelas verdaderos llamados de atención y queja frente al orden establecido y en nuestro medio circularon a manera de textos clandestinos. No cabe duda de que las nuevas ideas acerca de la estructura de la sociedad, estaban entrelazadas aquí con autores concretos y libros precisos, algunos muy livianos. Este tipo de literatura mezcla la descripción de hábitos, costumbres, hechos históricos; narraciones épicas y moralejas. No podemos decir que se trata de literatura profunda, pero a la edad de Manuel de Salas en el momento de solicitar este libro, no cabe duda de que su interés es más adolescente que maduro o docto.

8. Acerca del libro El Filósofo Sans Souci. Me parece que De Salas hace una mala traducción del título de esta obra. Encontramos un libro al parecer de mucha circulación en Europa hacia 1770 denominado Le philosophe sans prétention. Este libro tiene un nombre completo más complejo: Le philosophe sans prétention ou L'homme rare: ouvrage physique, chymique, politique et moral.

Debemos suponer que conoce el título de la obra en francés, pero que al recordarlo (al parecer en castellano) e intentar reconstruirlo en francés ocupa la palabra preocupación (souci), en lugar de pretensión. Esta obra que circula en Francia como folletín hacia 1770, es impresa en formato de libro dos años después de que De Salas la solicita (París, Clouiser, 1775, 350 
páginas). Su autor, que firmaba con las iniciales L. F., M. D. o L. M. D. F. y La Folie C-L es Louis-Guillaume de La Folie (1739-1780), nacido y muerto en Rouen, Francia (SeineMaritime). El libro es curioso y particular, pero coincide a mi juicio cabalmente con las inquietudes intelectuales de Manuel de Salas. No se trata de un libro superficial como los dos anteriores ya descritos; su fundamento es relativamente científico, de moderada liviandad, otorgada principalmente por la imprecisión de los datos que contiene, acordes con el conocimiento científico de la época. En los 27 capítulos, el libro toca casi todos los asuntos "científicos" de interés. Por mencionar sólo algunos, de una larga lista de temas que podríamos construir, señalaré:

Astronomía (acerca de los planetas, la luna); la gravedad; electricidad; física del fuego; metafísica; phlogistique; usos del carbón; física de fluidos; el vitriolo como ácido incontenible; alquimia, medicina y aspectos acerca de la atmósfera y el medio ambiente.

La lectura y análisis de las innumerables cartas y discursos, memoriales y representaciones de Manuel de Salas, muestra el conocimiento -tal vez algo salvaje- que tenía acerca de temas científicos y tecnológicos, que muy probablemente provenían de literatura como la señalada. El informe de 1801 acerca del invento de un tal Herrera, quien intentaba fabricar una máquina para "beneficiar metales" (fundir cobre) y otros de 1800 y 1802 dirigidos al Tribunal de Minería, contienen razonamientos acerca de la importancia de la lucidez, la observación y el ingenio, por encima -muchas veces- del conocimiento (empirismo y desarrollo tecnológico). Manuel de Salas demuestra tener además un conocimiento de los procesos propios de la minería, hecho que lo hace argumentar de buena forma sobre los beneficios económicos del desarrollo técnico de 
esa industria. De esta forma, observando la literatura que consultó, podemos comprender el origen de sus conocimientos.

\section{V.3. Otras influencias relevantes en Manuel de Salas}

En enero de 1801 Manuel de Salas, como Síndico del Consulado, escribe una Memoria que es leída por el secretario del organismo Tomás Turín. El texto, no obstante estar lleno de ideas propias de la Ilustración, aplaude y rinde pleitesía al rey. Con un lenguaje casi poético celebra los avances del reino en materias de educación e industria.

Lo interesante de este documento es que Manuel de Salas demuestra tener aquí un conocimiento bastante más acabado del concepto de "educación", ya no sólo del de "enseñanza". Menciona y alaba la obra de Campomanes Discurso sobre la educación popular de los artesanos de 1775. Este hecho nos entrega un detalle más completo de la visión de De Salas acerca de la educación (insisto, ya no sólo la enseñanza). En parte de esa Memoria se lee:

"Nuestra España, siempre fecunda de
grandes hombres, sólo espera para
producirlos que se les presente ocasión de
distinguirse. Poetas guerreros ilustres,
políticos consumados, teólogos insignes,
todo lo ha tendido cuando las
circunstancias lo han requerido, y más que
todo, cuando los dispensadores del honor
les han dirigido nuestras miradas benignas.
(...) huyen cubriéndose los ojos, el interés
particular, la indecisión, el amor a los
errores antiguos, el error a las verdades
nuevas; y sustituyéndose en lugar del fatal 
egoísmo aquel espíritu público que sólo halla morada en las almas virtuosas y grandes, se limpia el horizonte, y su libro de oro, La Industria y Educación Popular, se lee con entusiasmo". 45

Las ideas de Campomanes reflejadas en sus acciones y textos son bastante similares a las que defendió con posterioridad Manuel de Salas, particularmente la idea de entregar educación de primeras artes, letras y matemáticas a quienes se desempeñaban en oficios menores y mayores. No obstante, y a diferencia del chileno, Campomanes defendió la idea del ejercicio libre de la artesanía al margen de la gremialización de las actividades, debido a lo limitante que resultaba el trabajo de cofradías $^{46}$. Resulta de particular interés constatar este paralelismo entre ambos intelectuales, para los cuales la mezcla de intereses por el desarrollo de las personas, los oficios, y el establecimiento de un sistema de entrega de conocimientos básicos a modo de enseñanza elemental, son los pilares del discurso.

Pedro Rodríguez Campomanes y Pérez, Conde Campomanes desde 1780, escribió sus célebres textos Discurso sobre el fomento de la industria popular (1774) y Discurso sobre la educación popular de los artesanos y su fomento ${ }^{47}$ (1775)

45 Cfr. Salas Errázuriz, Juan., Escritos de Manuel de Salas relativos a el y su familia, Tomo 1, Santiago de Chile, Imprenta Cervantes. 1910, p. 216. y también en Archivo Nacional, Fondos Varios. Vol. 275.

46 Cfr. Rodríguez, Pedro. Conde de Campomanes. Discurso Sobre el Fomento de la Industria Popular. [en línea]. [23 de julio 2006]:

http://www.cervantesvirtual.com/servlet/SirveObras/02461674212913274754491/index.htm

47 Madrid, Imprenta de Antonio de Sancha, 1775, 480 páginas. Campomanes escribió además otros valiosos textos siempre bajo el sello de la ilustración, entre los que destacan La Respuesta 
basado en sus ideas sobre economía e historia. Los historiadores lo señalan como el representante típico del despotismo ilustrado, debido por una parte a la fuerte ligazón con la corona a la que contribuyó con ideas acerca del comercio libre y el desarrollo de la economía a base del trabajo de los privados; y, por otra parte, a su notoria preocupación por el campesinado y los artesanos. Sus permanentes acciones en desmedro de los bienes de la Iglesia, lo llevaron a apoyar la expulsión de los jesuitas y a favorecer el uso por parte de campesinos sin tierra del suelo agrícola sin cultivar de propiedad de la Iglesia.

Pero antes de continuar, me permito una breve reflexión respecto a la debilidad del concepto de artesano, en las postrimerías del siglo XVIII. Hasta aquí, y vista con los ojos del siglo XXI, la definición de artesano resulta confusa, pues se trata de una actividad que ejercida en el siglo XVIII es pobre, limitada y a su vez multifacética.

Pobre, debido a la falta de entrenamiento de los integrantes de los gremios, todos habiendo aprendido sus oficios por enseñanza hereditaria y con poca educación formal. Se suma a lo anterior la práctica de una actividad limitada, debido a que la excesiva gremialización y especialización de las actividades, impedía la formación de un trabajador multifacético y dificultaba a la vez, el trabajo conjunto con vistas a un plan mayor. Cambiar de disciplina, implicaba cambiar de gremio. Además, y para agravar la limitante, quien no estuviera gremializado no podía ejercer ningún oficio. El fenómeno fue descrito magistralmente por Campomanes, quien por lo mismo y como ya se dijo, se oponía a la gremialización de los artesanos:

fiscal sobre abolir la tasa y establecer el comercio de granos de 1764; Tratado de Regalía de amortización de 1765 y el Memorial ajustado sobre los abastos de Madrid de 1768. 
"Las competencias de jurisdicción se oponen a la industria tanto como a una bien ordenada policía...” Y agrega: “...la utilidad pública está en contradicción con estos cuerpos aislados y separados, porque de esa manera, el que no es del gremio no puede hilar, tejer ni ocuparse de tales faenas... ${ }^{48}$

Por último, el artesano resulta paradojalmente un personaje multifacético en la medida que un mueblista (ebanista) por ejemplo, bien podía arreglárselas tanto con la elaboración y tallado de un pórtico, como con la construcción de una humilde silla.

48 Cfr. Campomanes, Op. Cit. Cap. XV, p. 17. 


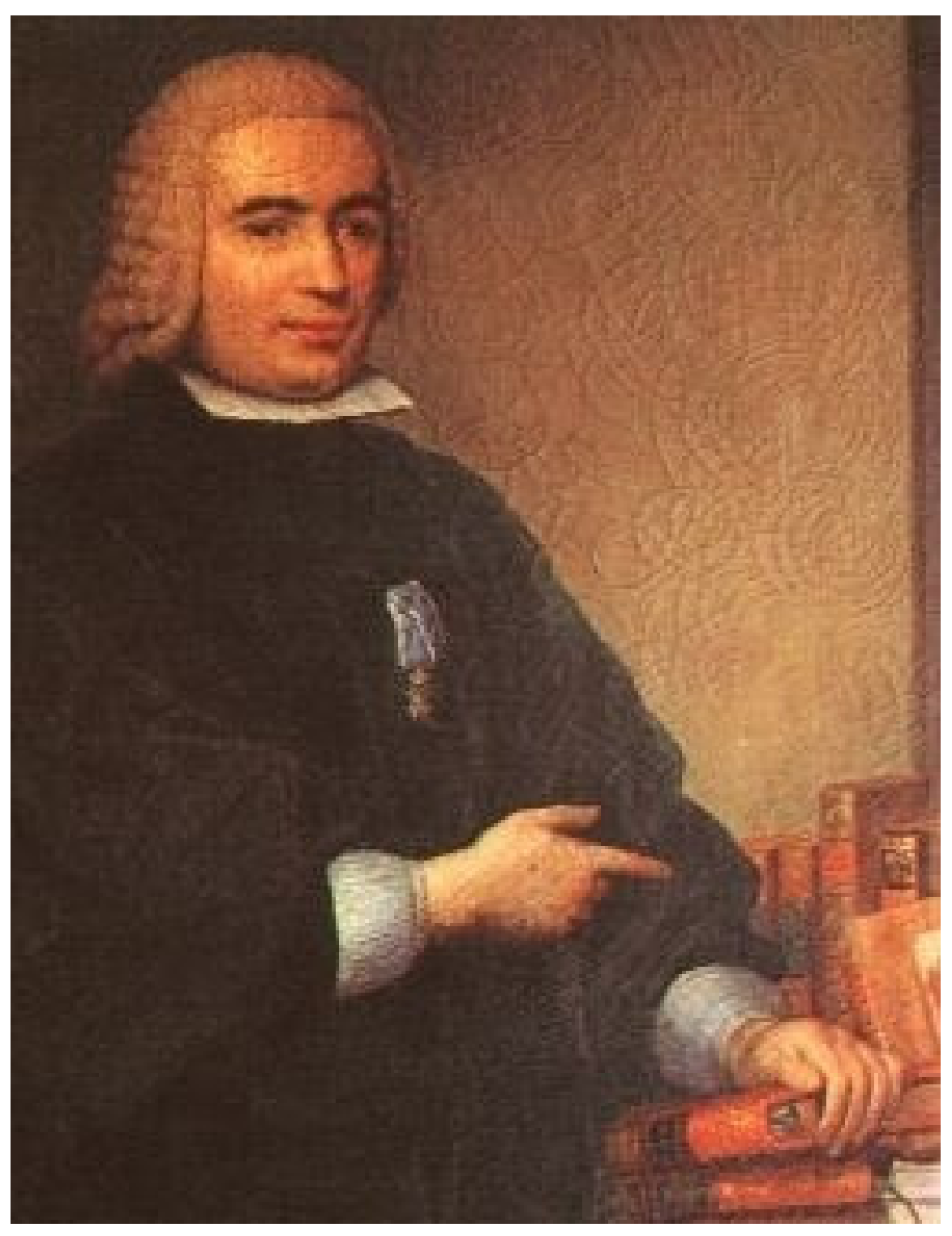

Lámina $\mathrm{N}^{\circ} 20$

Pedro Rodríguez Campomanes y Pérez, Conde Campomanes.

$1723-1803$ 
Sin embargo, la idea que comenzó a circular en Europa y que rápidamente fue capturada por la intelectualidad chilena, era que un adiestramiento básico sobre una base disciplinar común a todos los gremios, podía mejorar la cantidad y la calidad de la producción, en tanto constituía un valor base de conocimientos: el dibujo. La idea la vemos declarada por Campomanes:

"En los gremios de artesanos hay
poquísima enseñanza. Falta dibujo en los
aprendices, escuela pública de cada oficio y
premios de cada oficio y premio a los que
adelanten o mejoren la profesión. Todo es
tradicionario y de poco primor en los
oficios por lo común." (sic)

A diferencia del lenguaje más erudito de Campomanes, De Salas transparenta sus ideas sobre la relación entre maestro y aprendiz y la forma de enseñanza de los artesanos en el Reglamento del Gremio de Plateros, de fecha 9 de abril de 1802, en un nivel bastante más concreto. En una mirada más contemporánea, podemos decir que su discurso es paternalista y autoritario, debido a que protege y obliga, y aún con menciones sobre lo cristiano, más bien por hábito que por convicción. Veamos el artículo 8 de ese reglamento enviado al presidente del Gobierno de Chile, Muñoz de Guzmán ${ }^{50}$ :

$$
\begin{aligned}
& \text { " } 8 .^{\circ} \text { Durante este tiempo, será obligación } \\
& \text { del maestro enseñarle el oficio y la doctrina } \\
& \text { cristiana, darle buen ejemplo, procurar que } \\
& \text { aprenda á leer, escribir, la aritmética } \\
& \text { vulgar y el dibujo, como requisitos todos, } \\
& \text { sin los que jamás podrá poner tienda }
\end{aligned}
$$

49 Ibídem, p. 18

50 Reglamento del Gremio de Plateros. Biblioteca Nacional de Chile 
pública. Deberá vestirlo modestamente, darle alimentos y cama proporcionada a un muchacho pobre. Si al entrar el aprendiz trae vestuario y cama, se le señalará menos tiempo que al que sea necesario costearle uno y otro, al arbitrio del Juez, para que la mayor duración del servicio compense el gasto. Podrá ser corregido de sus faltas o desaplicación, pero del modo que lo sería un hijo, y sin usar jamás del afrentoso azote, que solo sirve para envilecerlos y prostituirlos."

Como podemos ver, la idea de enseñar a una persona, se asociaba a la noción de maestro, es decir, una suerte de padre que orienta al aprendiz en su vida, para convertirlo en "oficial" que, como artesano, equivale al grado siguiente luego de la graduación como aprendiz. Una idea paternalista de la enseñanza, bastante vertical, pero que sin embargo pone al aprendiz a resguardo de los abusos que se podían cometer. Sin duda esta idea contiene además un perfil ciertamente político y social. Debo señalar que la adquisición de un nivel de educación en los gremios de artesanos, hasta llegar al grado de "oficial mayor" de un gremio cualquiera, ubicaba al portador en una clase social más alta, lo que -una vez concluida la coloniaequivalía a ser ciudadano con derecho a voto ${ }^{51}$.

El mecanismo de enseñanza operaba como un internado y el maestro hacía las veces de profesor de tres materias a la vez.

51 Salazar. Op. Cit., p. 193. Este autor hace mención de que en el reglamento de las elecciones de 1823, Egaña (de seguro bajo instrucciones del presidente R. Freire, nos dice el autor) señaló en el artículo $5^{\circ}$ que entre otros "habitantes libres" tenían derecho a voto los maestros mayores de un oficio. 
Luego del egreso de la etapa de aprendizaje el artesano quedaba obligado a trabajar con su maestro ${ }^{52}$.

Pero la estructura de la Academia de San Luis no sólo tuvo influencias teóricas. De varias cartas de Manuel de Salas, podemos deducir que utilizó como modelo de academia, entre otras, la estructura de las escuelas de artesanos de España. 



\section{LA ACADEMIA DE SAN LUIS, PRIMERA INSTITUCIÓN QUE IMPARTE UN CURSO DE DIBUJO EN CHILE}

De las cartas, representaciones, memoriales, notas y actas, podemos acordar que la noción de enseñanza que poseía Manuel de Salas era bastante más adelantada que la de sus pares chilenos. En relación a la enseñanza del dibujo, puedo señalar que no existe un antecedente de que alguien, en años o décadas anteriores, hubiera tenido la claridad de pensar y concretar un curso de dibujo para jóvenes y adultos, es decir, más allá de la enseñanza primaria o "de primeras letras". De Salas además estableció tres principios claves en su noción de enseñanza:

a) Lo primero, podríamos decir, es un principio de simetría, igual relevancia o no exclusión. En otras palabras, que todas las disciplinas son relevantes, sin que existan áreas de primera, segunda o tercera categoría. De Salas lo plantea claramente ${ }^{53}$ y con ello marca una línea divisoria entre una universidad y una academia, la primera dedicada a la formación de la clase dirigente y orientada a los estudios superiores (filosofía, leyes, artes -entendida como retórica y humanidades y posteriormente medicina); la segunda entendida como una formación práctica más vulgar, tendiente a la generación de una mano de obra altamente calificada y vinculada estrechamente al comercio y la industria $^{54}$.

"No debiendo dudarse de la necesidad que hay de tener principios de geometría, aritmética y dibujo, para tratar con acierto la agricultura, comercio e industria (...) sin la aritmética no habrá un comerciante capaz de hacer un cálculo exacto ni una combinación útil, ni de expedirse con

53 Carta del 1 de diciembre de 1795. Ver la carta completa en las páginas siguientes de este texto.

54 "Academia de Práctica" le llamará la Junta Nacional de Gobierno en el decreto del 2 de agosto de 1813 . 
seguridad; sin el dibujo, no pueden hacer las artes el menor progreso; $y$, finalmente el trabajo de las minas, tan recomendado, nada adelantaría sin unos elementos que conducen al acierto de la metalurgia, mineralogía, maquinaria y química."

b) Lo segundo, que la enseñanza del dibujo, en el proyecto de Manuel de Salas, derivó por razones prácticas en la noción de "dibujo del natural", lo que implica una práctica con modelos reales ${ }^{55}$ y no una enseñanza basada en las nociones de dibujo lineal, tan acostumbrada en aquella época y que resultaba la mezcla ideal entre geometría y dibujo. Aquí, por el contrario, se trató de dibujo de formas, realizado con modelos tridimensionales reales.

"Como en los principios de un
establecimiento es difícil proporcionar todos
los artículos que deben constituirlo, se
empezó por el estudio del dibujo al
natural..."

c) Lo tercero, es que el dibujo puede enseñarse adoptando un modelo instruccional, lo cual implica la necesidad de expertos como maestros y la aplicación de un plan sistemático de instrucción. En este modelo, De Salas genera una vinculación entre dibujo y arte, asociación que si bien era obvia por la práctica habitual del pintor que enseña a sus

55 En su informe sobre la academia, De Salas menciona que las clases de dibujo se realizan por la noche y para ello ha dispuesto el trabajo de dibujo con 100 modelos. En: Salas E., J. Op. Cit. pp. 573 y 574 .

56 Informe de Manuel de Salas al rector de la Real Universidad de San Felipe, acerca de un profesor de la Academia de San Luis que pretende la Cátedra de Matemáticas en dicha Universidad. Noviembre 16 de 1802. 
discípulos $^{57}$, no lo era al momento de hablar de enseñanza o instrucción pública.

En su Representación al consulado sobre la necesidad de establecer un aula de matemáticas, escrita en Santiago de Chile el 1 de diciembre de 1795, Manuel de Salas vincula dibujo con arte y lo separa de la enseñanza de la geometría, pero manteniendo la estrecha concomitancia entre ambos saberes, como lo indicaba la tradición renacentista. La enseñanza sistemática del dibujo fue entonces una propuesta destinada a acercar la práctica de la representación al arte, pasando obviamente por un sistema de trabajo vinculado al perfeccionamiento gremial y a la enseñanza de $\operatorname{artesanos}^{58}$.

A continuación, transcribo dicha carta o representación al Consulado ( se ha respetado la ortografía y sintaxis del original):

"Señores de la Junta del Consulado de Chile:

No debiendo dudarse de la necesidad que hai de tener principios de jeometría, aritmética i dibujo, para tratar con acierto de la agricultura, comercio é industria, parece que de ningún modo pueden VV.SS. llenar mejor el encargo de proteger $i$ promover estos tres ramos que proporcionando á la juventud tales conocimientos. Ellos son esenciales para los objetos enunciados, pues sin geometría no se pueden pasar los umbrales de la

57 Véase lo referido a Francisco de Escobar y Damián Muñoz, ambos pintores, y Crisóstomo Atahualpa, escultor, en el capítulo III de este documento: Orientaciones estéticas en Chile en el período estudiado.

58 Véase lo referido a Otras influencias relevantes en Manuel de Salas en V.3, en este documento. 
física, i sin la ayuda de ésta la tierra ni varía de producciones, ni los usos de ellas son conocidos en toda la extensión de que somos capaces; sin la aritmética no habrá un comerciante capaz de hacer un cálculo esacto ni una combinación útil, ni de expedirse con seguridad; sin el dibujo, no pueden hacer las artes el menor progreso; $i$, finalmente, el trabajo de las minas, tan recomendado, nada adelantaría sin unos elementos que conducen al acierto de la metalurgia, mineralogía, maquinaria $i$ química.

Convencido de esta verdad, creo de mi obligación proponer los medios de ocurrir á este defecto, esperando que VV.SS. abracen con gusto una ocasión de ser sólidamente benéficos.

Lo conseguirán destinando la sala inmediata al tribunal, que durante el día sirve de recibimiento ó antesala, para que en ella oigan al principio de la noche, lecciones de estas tres partes de las matemáticas los alumnos que quieran, sin haber más gasto que el de papel. Así se iniciarán en unos elementos que convienen á todas las profesiones i son absolutamente necesarios para las ciencias esactas, en las horas que, cuando no se cumplen mal, se desperdician, dedicándolas al ocio, que hace frecuentemente inútiles $i$ aun perjudiciales las más excelentes cualidades.

Dos requisitos necesarios $i$ cuya falta podría detener la ejecución de este rasgo de amor al público por parte de VV.SS., que 
son maestros y modelos, los hay por felicidad. El maestro es don Joaquín Toesca, arquitecto y aprobado por las academias de Roma y San Fernando, i cuyo talento es notorio; i los modelos completos los tengo i ofrezco dar graciosamente.

El costo para colocarlos, el de bancos, mesas y candeleros ha de ser corto; el de luces $i$ salario del maestro subirá a seiscientos pesos anuales. Puede hacerse del fondo del Consulado, pues á este fondo difícilmente se le encontrará empleo más conforme á su destino. Estoy seguro que la benignidad del rey lo aprobará, tal vez mandando que se costee de otro ramo, atendida la escasez de éste. Para el caso de que uno ú otro no suceda, me obligo á reintegrar cuanto se haya consumido hasta el día en que llegue la noticia de la real voluntad; $i$ si aún así ocurre una dificultad, pueden VV.SS. mandar hacer el gasto del salario que me corresponda como Síndico, á que añadiré la cantidad en que éste sea alcanzado.

Para verificarlo, se servirán VV.SS. mandar que se tenga de todo una prolija cuenta $i$ elegir un sujeto que cuide particularmente de llevar á efecto esta empresa, ó dividir la atención á ella entre varios, ó como lo tengan por más conveniente, precediendo á todo la licencia del Superior Gobierno.

Santiago de Chile i Diciembre 1. ' de 1795” 
Este documento es el primero en que Manuel de Salas enuncia en forma oficial la idea de crear una academia, hecho que aparece junto a la necesidad de establecer un aula de matemáticas. Tiene mayor valor aun, y es lo que deseo poner de relieve aquí, por cuanto es la primera declaración escrita que emite un chileno expresando la importancia de la impartición reglada de tres disciplinas en igualdad de condiciones: el dibujo, la aritmética y la geometría.

Como podemos ver, en dicha carta el dibujo aparece como una materia agrupada junto a las matemáticas y la geometría, las cuales según De Salas indudablemente aportan al desarrollo del comercio, la agricultura y la industria. La carta es bastante pobre y desordenada en sus fundamentos. De hecho, el autor no expone los resguardos teóricos que lo llevan a sostener tales afirmaciones. Salvo el argumento, bastante obvio, de que el comerciante sin matemáticas no podrá llevar una buena administración y menos hacer cálculos exactos, los alegatos en favor de la física, la geometría y el dibujo, aparecen bastante desprovistos de fundamentos y, por el contrario, cargados de sentido común. Subrayo:

"...sin el dibujo, no pueden las artes hacer el menor progreso..." dice Manuel de Salas en la carta.

Pese a que la representación se eleva al consulado sólo para solicitar el aula de matemática, el contenido se compone de aproximaciones a la química, la metalurgia, el dibujo, la física, la mineralogía y la mecánica.

En los años siguientes Manuel de Salas repetirá incansablemente los beneficios de crear una academia. El 12 de enero de 1796, el Consulado le responde por escrito a Manuel de Salas. La carta con la negativa a crear la Academia dice entre otras cosas ${ }^{59}$.

\footnotetext{
"Vista la representación del Síndico sobre que da cuenta del Consulado se fomente la
}

59 Salas E., J. Op. Cit., p.569. 
instrucción de los jóvenes en las artes $i$ en las matemáticas, geometría, aritmética i dibujo, precisas para tratar con acierto de la agricultura, comercio é industria, en la Junta de Gobierno resolvieron los SS. que la componen que por ahora es inadaptable el proyecto aunque laudable por los objetos de pública utilidad que embebe en sí con respecto á que los fondos del Consulado aun no sufragan para la moderada dotación de sus empleados."

Sin cansancio, De Salas ese mismo día escribe una nueva carta, rogando por la Academia, lo cual da origen a una Real Orden emitida el 24 de julio de 1796, firmada por el Rey en Aranjuez ${ }^{60}$. Esa orden pide que se ejecute la creación de una Escuela de Aritmética, Geometría y Dibujo ${ }^{61}$, pero no le da aún la existencia legal.

No parece extraña la relación entre las tres áreas señaladas (geometría, aritmética y dibujo), que se repite muchas veces en sus documentos. Sabemos que las influencias que recibe Manuel de Salas se orientan claramente por las ideas de Palomino; otras fuertes influencias recibe de su admiración por Grecia, de la escuela renacentista (Leonardo, Durero) y de la obra del matemático Samuel Marolois ${ }^{62}$, entre otros, todos los cuales no hacen más que reunir las nociones de matemáticas, geometría y dibujo, entendido éste último como la representación visual concreta de asuntos más abstractos.

60 Archivo Nacional de Santiago de Chile, Vol. 754.

61 Todos estos datos están contenidos en el informe del 10 de abril de 1801, que elabora Manuel de Salas acerca del funcionamiento de la Academia, y que dirige a don José Santiago Concha, Presidente de Chile.

62 Remitirse a los detalles ya estudiados en V.2, de este documento. 
Dieciséis meses después de la real orden que la crea ${ }^{63}$, la Academia obtiene el decreto que le da existencia legal (31 de enero de 1798) ${ }^{64}$, denominándose San Luis en homenaje a la reina Luisa, esposa de Carlos III, a quien nos referimos anteriormente.

La Academia de San Luis recibe a sus primeros alumnos el 18 de septiembre de 1797, con un presupuesto inicial de 1.500 pesos por una sola vez y un presupuesto anual de 2.375 pesos. De Salas pide que sean erogados por el Ayuntamiento, el gremio de mineros y el comercio. Sólo un año después, en $1798^{65}$ se ordena al Tribunal de Minería ${ }^{66}$ que colabore con 1.000 pesos más al año.

El curso de dibujo comenzó a funcionar en las noches en una casa arrendada ubicada frente a la del propio Manuel de Salas en las cercanías de las actuales calles San Antonio con Santo Domingo, hoy pleno centro de Santiago, pero que en esa época constituía el inicio de la periferia de Santiago (proximidades del río Mapocho). Partió con 100 modelos de dibujo, candeleros, algunas mesas y bancos ${ }^{67}$. De todas las cartas que escribe Manuel de Salas podemos colegir que:

a) Martín Petri, de paso en Chile, camino a Perú, se estableció en Santiago solamente 16 meses, lo suficiente para ser, junto a Joaquín

63 De seguro esta gestión contó con la ayuda y el beneplácito del Presidente Gabriel de Avilés y del Fierro, que por fortuna para De Salas había asumido su cargo en septiembre de 1796.

64 Archivo Nacional de Santiago de Chile. Vol. 747.

65 Me refiero a la Real Orden del 31 de enero de 1798 artículo № 14.

66 Luz María Méndez define al Tribunal de Minería como “...la proyección institucional de la organización minera que la corona española adoptó para sus posesiones americanas a fines del siglo XVIII.” El tribunal de Minería entró en vigencia el 22 de diciembre de 1787 . Hacia 1819 y con el gobierno de O’Higgins se denominó Administración de Minería. En: Catálogo del Archivo del tribunal de Minería, por Méndez, L. M. Revista de Derecho de Minas y Aguas. Vol. 1, Santiago de Chile, 1990, pág. 403.

67 Datos que constan en la "Representación al consulado sobre la necesidad de establecer un aula de matemáticas”. Manuel de Salas, diciembre 1 de 1795. 
Toesca, uno de los dos profesores fundadores de la Academia, el primero en dibujo, el segundo en aritmética y geometría.

b) La puesta en marcha de la Academia con un programa pobre pero "moderno" como éste, que incluía por primera vez en Chile cursos de aritmética, geometría y dibujo, se debió al oportuno aprovechamiento de una casualidad: la cercanía personal de Manuel de Salas con las Bellas Artes y la presencia del profesor Petri de paso en Chile. Esta "cercanía personal" de De Salas con las Bellas Artes se confirma a la partida de Petri: mientras que el curso de Química tuvo un intento de comenzar recién en 1799 ya que no había profesor de esa disciplina, ni dinero para contratarlo, De Salas se preocupa más por el curso de dibujo; encuentra y contrata rápidamente a un reemplazante de Petri, el maestro Ignacio Fernández Arrabal, segundo profesor de dibujo en Chile, artesano platero de la Casa de Moneda y ex alumno de la Academia de San Luis. 


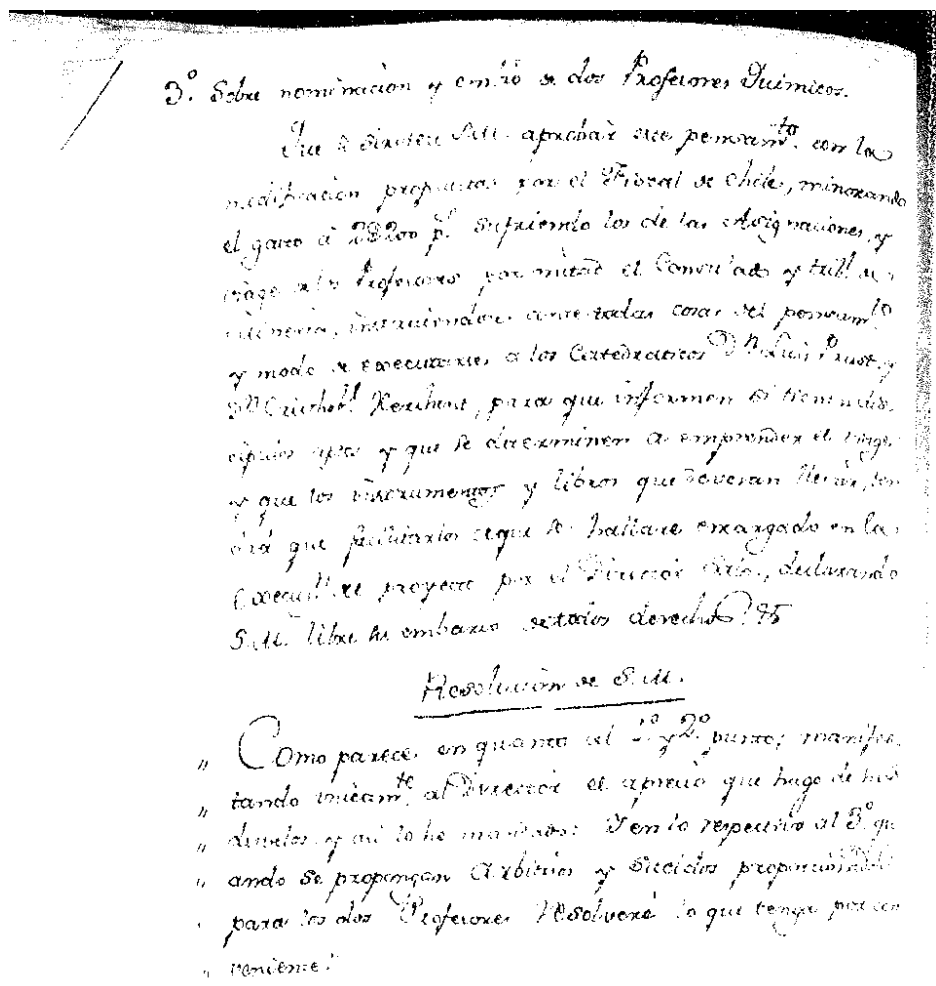

Lámina $\mathrm{N}^{\circ} 21$

Parte final de la carta (28 de julio de 1805) de respuesta del rey de España, ante la consulta del Consejo de la Real Audiencia de Santiago que solicitó recursos financieros para solventar el sueldo de dos profesores de química. Nótese que aún en esa fecha la enseñanza de la química no estaba asegurada en la Academia de San Luis. La resolución de S.M. (en la parte inferior de la carta) señala que se autorizan los dineros para sueldo de dos profesores.

(Archivo Nacional de Santiago de Chile, Fondos Varios, vol. 156) 
Muchos de los estudiantes de la Academia eran artesanos, a quienes -de acuerdo con el Reglamento- para pasar a la tercera etapa denominada "maestro" (de artesanos) se les recomendaba saber dibujar. Estas clases se realizaban en forma gratuita y fuera de las horas de trabajo, según señala el mismo reglamento en su artículo $14^{\circ}$. Tal vez por la necesidad de atender a los aprendices fuera de las horas de trabajo, la Academia de San Luis ofrecía el curso de dibujo en jornadas vespertinas: Los gramáticos asisten de día a la sala que sirve para el dibujo por la noche... dice de Salas en una carta. ${ }^{68}$

Sin embargo, el 12 de agosto de 1802, Manuel de Salas debe escribir una nueva carta, esta vez dirigida al presidente, rogando para que no ponga en vigencia la Orden Real del 7 de junio de 1801, que suspende el pago de 1.000 pesos del Tribunal de Minería. En la práctica, las cuentas de la Academia estaban siendo objetadas. El Tribunal de Minería no consideraba a De Salas como uno de sus favoritos, ya que el director de la Academia había objetado siempre que dicho Tribunal no hubiera sido el que impulsara un colegio de minería, como lo ordenaba el propio estatuto del Tribunal. Esta falta la denunciaba De Salas públicamente al decir, por ejemplo, que la enseñanza de la minería, la geometría, la aritmética y el dibujo "está expresamente encargada al gremio de mineros" (Tribunal de Minería) ${ }^{69}$.

Al cortársele la subvención de 1.000 pesos, se ahogaba a De Salas, forzándolo a cerrar la Academia.

68 Carta de Contestación a los reparos hechos por el Tribunal de Minería a las cuentas de los gastos de la Academia de San Luis, dirigida al presidente José de Santiago Concha el 18 de septiembre de 1801, donde De Salas expone las precarias condiciones de trabajo. Archivo Nacional de Chile, Fondo Varios, vol. 155.

69 Esta observación la realiza don Miguel Luis Amunátegui, basado en la lectura que hizo en su momento de dichos estatutos, hoy desaparecidos. Ver Amunátegui Miguel Luis, Don Manuel de Salas. Tomo 1. Santiago de Chile, Imprenta Nacional. 1895, p. 75. Sin embargo este hecho se denuncia en tres representaciones de De Salas dirigidas al Tribunal de Minería y al Presidente. 
"La voluntad del Rey, no es extinguir una Escuela, a cuyo favor a expedido siete Ordenes Reales..." dice De Salas al Presidente, en su carta donde solicita amparar la subsistencia de la Academia, y agrega:

"Lo que se manda (el Rey) es únicamente suspender sus rentas por ahora, esto es, mientras subsisten las causas que representó el Tribunal de Minería. Siendo pues éste el término de la Real Orden, siendo de tan malas consecuencias cualquiera otra inteligencia que se le dé, y no resultando inconveniente alguno de concebirla así, no dudo que convendrán en su permanencia los mismos Cuerpos á quienes debe el ser." 70

El argumento, propio de un abogado, se centraba en los hechos y no en las consecuencias, por lo que la Academia no se cerró. Más aún, en 1803, se otorgaban premios en dinero a los mejores alumnos. Según las cuentas de la Academia, se destinaban doscientos pesos entre los seis mejores alumnos de matemáticas.

Como se ve, las órdenes emitidas por el rey en lo concerniente a esta Academia fueron durante mucho tiempo confusas y como otras, llegaban muchas semanas después de emitidas, situación que aprovechaba Manuel de Salas para proceder, en el espacio de tiempo que quedaba entre cada carta y su respuesta. No obstante, estos documentos no alteraron la existencia de esta institución, pese a que las

70 Carta de Manuel de Salas enviada al Gobernador (Presidente) de Chile Luis Muñoz de Guzmán, el 12 de agosto de 1802. Archivo Nacional de Chile, Fondo Varios, vol. 155. 
órdenes que mandaban suprimir la subvención y otras que derogaban la orden anterior eran bastante tajantes. ${ }^{71}$

Finalmente, en 1806 llega una orden, firmada en agosto de 1805, que le da vida a la Academia. Esta orden, curiosamente, llegaba nueve años después de que los primeros alumnos ingresaran a la Academia (septiembre de 1797).

Del listado de profesores de la Academia de San Luis podemos inferir el éxito bastante relativo de esta iniciativa académica, lo difícil de sostener una presencia académica en el tiempo y el peso de las respectivas disciplinas que allí se enseñaron. En su mejor momento, alrededor de 1810, la Academia contó con 96 alumnos en todos sus cursos. Se había cambiado de casa y su rector era Francisco de la Puente, maestro de latín.

$71 \mathrm{Al}$ respecto el Archivo Nacional de Santiago guarda sólo algunos documentos: En el volumen 749 , II, se encuentra desaparecido el documento de 7 de junio de 1801, con la real orden que suprime la creación de la academia de geometría (sic) y dibujo (como menciona el catálogo Capitanía). El 18 de agosto de 1805 se emite una nueva orden que deroga la anterior, dándole vida a la Academia. Sin embargo y de manera confusa hay además una resolución del rey sobre el establecimiento de esta Academia de fecha 23 de julio de 1805. (Archivo Nacional de Chile, vol. 245 , pieza $\mathrm{N}^{\circ} 15$, Fondo Varios dos fjs. Como se puede ver, a estas alturas Manuel de Salas ya llevaba siete años y once meses de marcha con su Academia. 


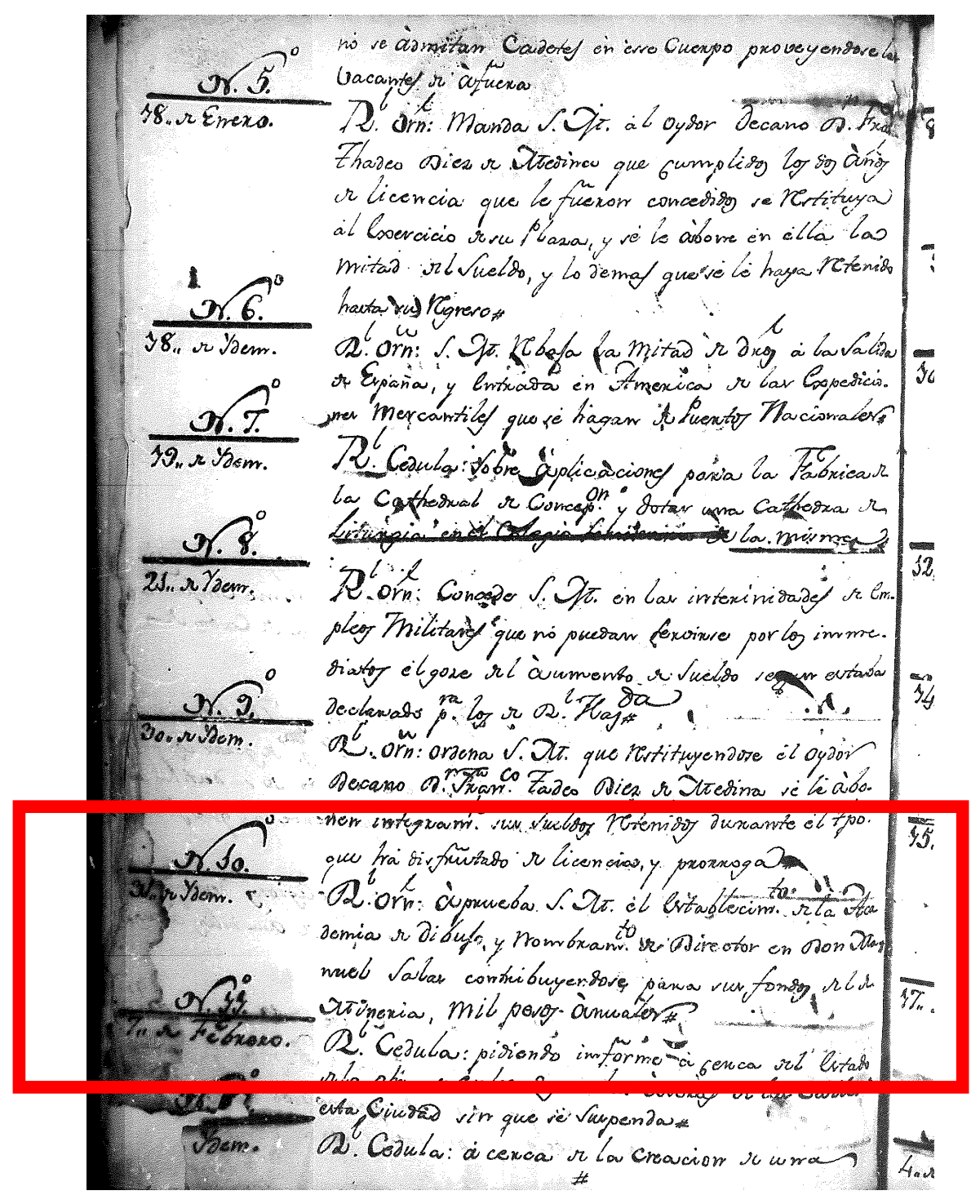

Lámina $\mathrm{N}^{\circ} 22$

Real Orden del 31 de enero de 1798, que aprueba el establecimiento de la primera Academia de Dibujo en Chile. Nótese que el decreto que la crea definitivamente llega a Chile seis años más tarde. (Archivo Nacional de Chile. F. Capitanías. Volumen 1201 747) 
Láminas $\mathrm{N}^{\circ} 23,24$ Y 25

Real Orden llegada a Chile en 1806 que crea definitivamente la Academia de San Luis. (Archivo Nacional de Santiago de Chile). Tres folios

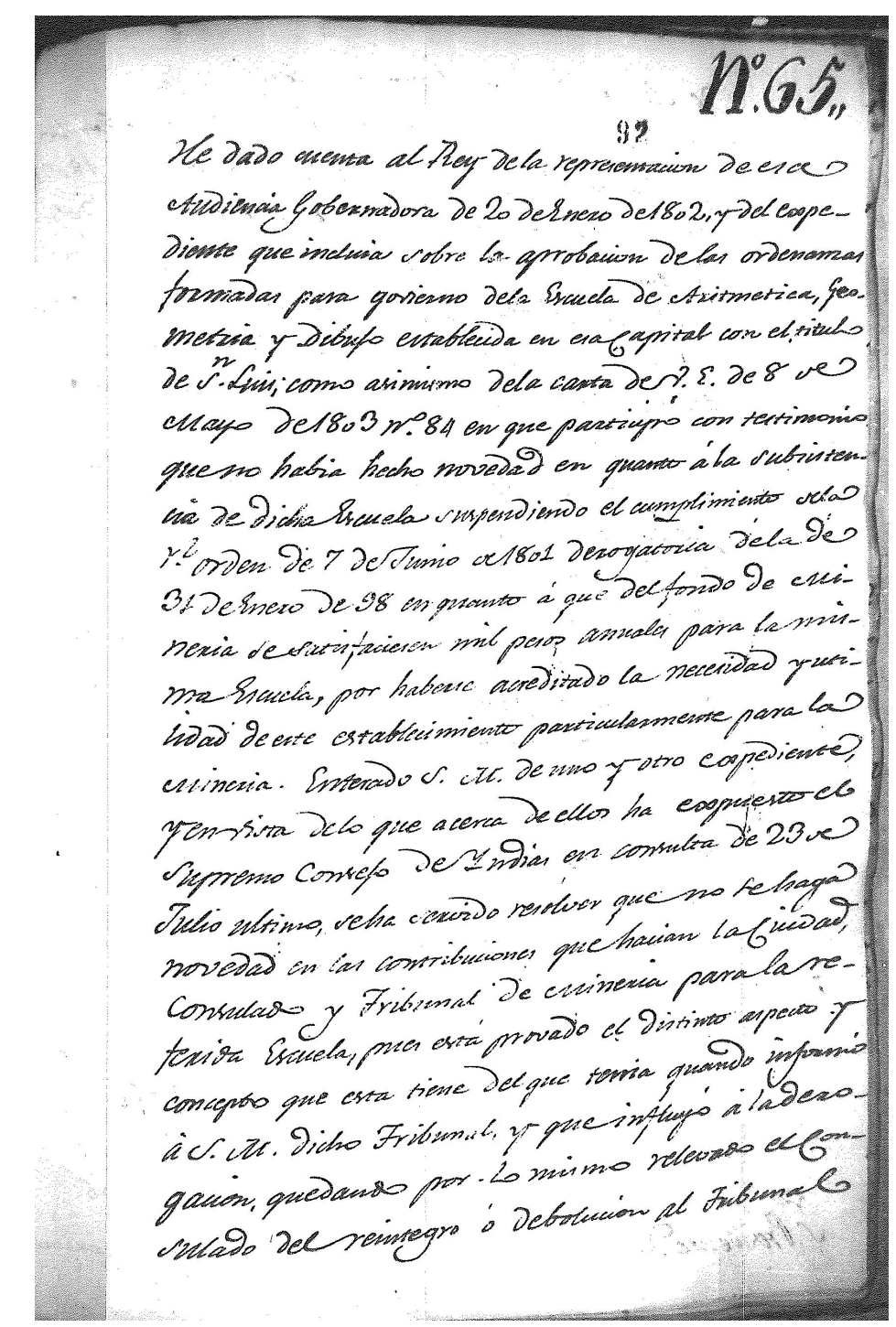

(folio 65-1) 


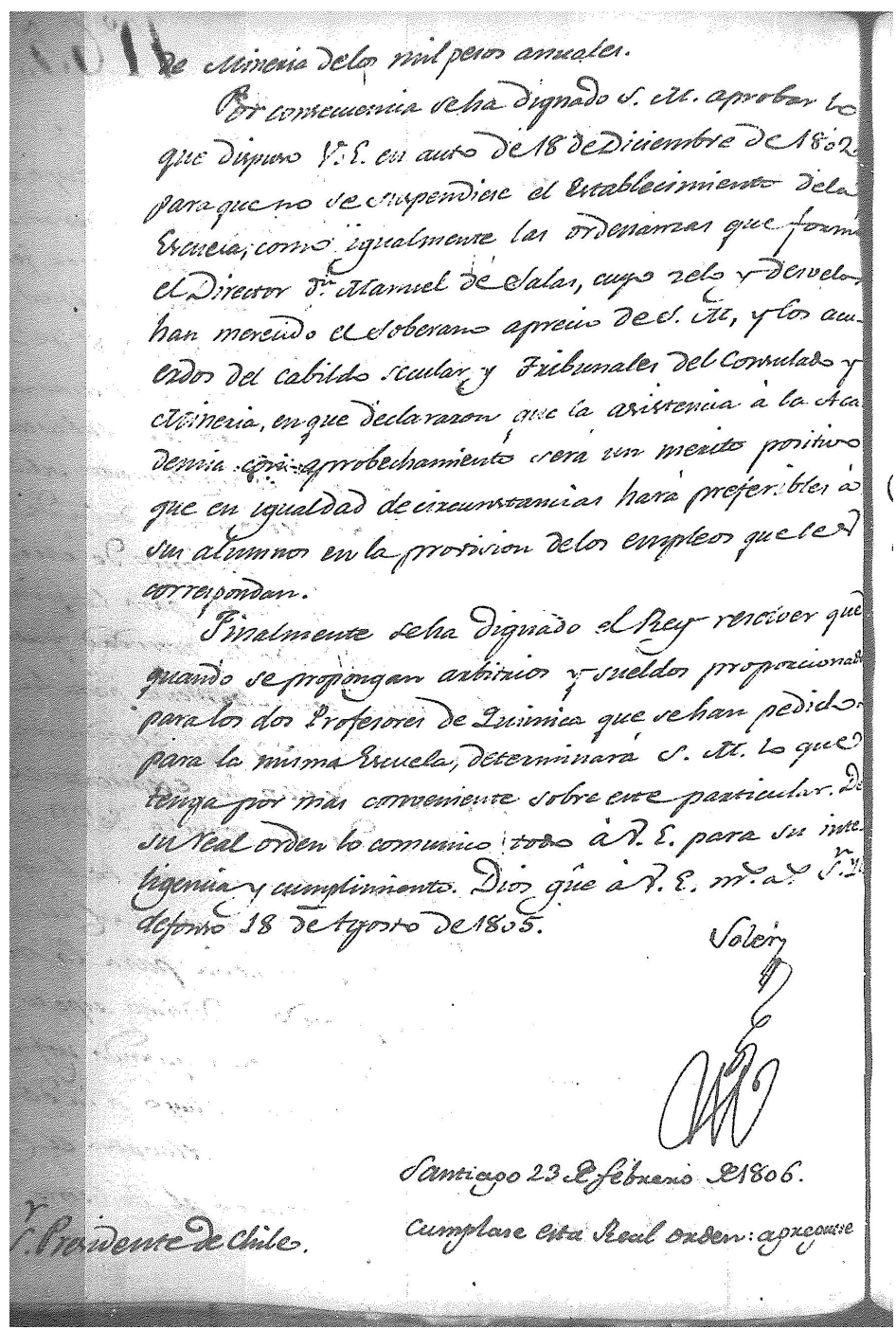

(folio 65-2) 


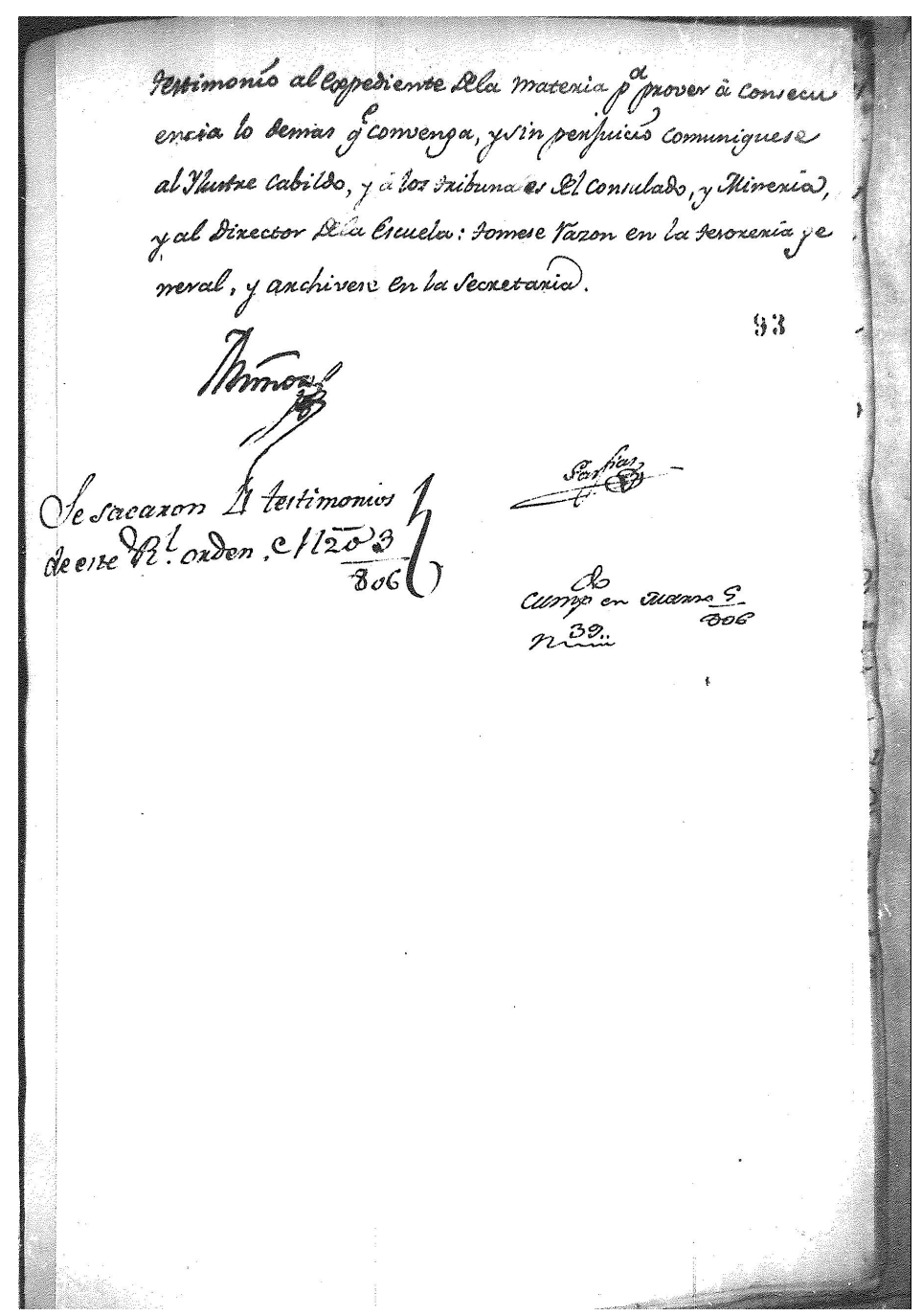

(folio 65-3) 
Revisemos la nómina de docentes entre 1797 y $1810^{72}$ :

Dibujo: a cargo de Martín Petri desde el 18 de septiembre de 1797 al 17 de diciembre de 1798. \$400 anuales de sueldo. Ignacio Fernández Arrabal (diciembre de 1797 a diciembre de 1799).

Matemáticas: Joaquín Toesca, arquitecto italiano discípulo de Sabatini; y desde el 1 de octubre de $1799^{73}$, Agustín Marcos Caballero (Capitán de Milicias), que en 1802 dictaba además lecciones de hidráulica. Como profesor auxiliar para un segundo curso, se nombró a partir del 1 de septiembre de 1800 al teniente de milicias José Ignacio Santa María y a Isidoro Errázuriz, quien en esa misma fecha asume como auxiliar y desde el 9 de enero de 1802 se dedica a preparar a los alumnos de la Academia para que rindan en el mes de febrero de ese año los exámenes públicos de aritmética (con principios de álgebra). Sueldo de $\$ 300$ anuales para cada uno. En 1802 la cátedra contaba con un ayudante, Manuel José Villalón. Desde 1804 la cátedra es dirigida por Miguel de Atero.

Primeras letras: José Riveros desde el 1 de octubre de 1798. \$150 anuales de sueldo. Fue sucedido por Diego Antonio Elizondo. Desde el primero de marzo de 1802 asume Andrés Maruri, quien ejerce hasta septiembre de 1804 y es sucedido por Manuel Martínez.

Gramática Latina: Pedro Ramón de Silva Bórquez desde el 18 de septiembre de 1797 al 17 de octubre de 1800. Sueldo de $\$ 250$ anuales. Desde 1802, asume el monje Franciscano Francisco de la Puente, ya mencionado.

72 Libro de cuentas de la Academia. Biblioteca Nacional de Chile. Puede consultarse además a Amunátegui Solar en Los Primeros años del Instituto Nacional (imprenta Cervantes. Santiago de Chile, 1889).

73 En la carta del 16 de noviembre de 1802, menciona el 30 de septiembre como la fecha exacta de dicha incorporación. 
Como se puede observar, no existen datos acerca de uno o más profesores de química. Debo recordar lo ya dicho en relación a que los fondos de la Academia debían provenir en parte del Tribunal de Minería, y ese aporte se justificaba en tanto se creara un curso de química. En la lámina $\mathrm{N}^{\circ} 21$ expuse que en 1805 ya había problemas de dinero para contratar a dos profesores de esta disciplina. Se trataba entonces de los profesores Cristóbal Marchant y Luis Prust, para quienes el Rey concedió los dineros. En otra carta de 1805 se maneja la idea de crear un curso de mineralogía bajo la conducción de Francisco Rodríguez Brochero, ensayador de minerales de la Casa de Moneda. Esta nómina de profesores del Libro de Cuentas de la Academia, nunca mencionó la existencia real de algún profesor de química y mineralogía.

Un informe sobre la marcha de la Academia, presentado por Manuel de Salas el 10 de abril de 1801, expone las causas que lo movieron a establecer esta institución. De aquí podemos inferir que el modelo empleado para impulsar su iniciativa fue netamente español: " $E l$ ejemplo de otros establecimientos idénticos, como los de Madrid, Sevilla, Málaga, Segovia, Vergara y Gijón, en que se ha adoptado un método igual para los mismos fines, persuade de su conveniencia",74 Líneas más adelante declara que la química y la metalurgia se entregará tal como enseñaba como en Nápoles, Puzol, Cumberland, Lemnos y Laravia.

En 1810 y luego de que se estableciera la primera Junta Nacional de Gobierno $^{75}$, Manuel de Salas abandona su rol obediente de la corona y del Rey. Aliado ahora a las emergentes ideas criollas que luchan por el fin de la colonia, adopta un perfil bajo pero siempre activo en los acontecimientos que ayudaron a la independencia. El destino de la Academia cambió, como todo en Chile en esa época, con los turbulentos sucesos que siguieron a la proclama de la Primera Junta Nacional de Gobierno.

74 Salas E., J. Op. Cit. p.579

$75 \mathrm{Me}$ remito a lo ya señalado en el capítulo $\mathrm{V}$ de este documento. 
Casi en forma simultánea a los acontecimientos políticos, y tal vez previendo que una Academia nacida bajo el amparo real, no tendría mayor futuro en la nueva estructura de país, Manuel de Salas declara la necesidad y voluntad de unir la Academia al Colegio Carolino (conocido también como Colegio de San Carlos o Convictorio Carolino).

En su carta Manuel de Salas deja entrever su ánimo de refundar el curso de dibujo, cerrado hacía ya 11 años.

"Llenaría todas estas miras y deseos del
público el establecimiento de un colegio en
que se enseñasen los principios de toda
buena educación, esto es las primeras
letras, idioma, dibujo, moral, aritmética,
geometría y demás que sirven á formar el
juicio y preparar para estudios más
serios. "76.

No hay cursos de dibujo en Chile en aquella época. La Junta Nacional, como se verá luego, no toma en consideración la sugerencia contenida en esta carta. No obstante, los archivos dan cuenta de un movimiento de educación público y privado, de explosivo crecimiento, que será el que sostiene la enseñanza en este período de caos. En efecto, luego de la creación del Instituto Nacional -al que me referiré extensamente en los párrafos que siguen- se crean entre 1817 y 1818 la primera Academia Militar y la Academia de Guardiamarinas; luego, en 1822, el monje Camilo Henríquez plantea abrir una escuela industrial. José Joaquín de Mora, venido de Argentina, abre en 1828 el Liceo de Chile y en forma paralela viaja desde Francia el profesor Pedro Chapuis, quien intenta organizar un colegio particular. Fracasado el plan, el grupo de

76 Carta de Manuel de Salas del 20 de febrero de 1811, dirigida al Presidente y a los vocales de la Junta Provisional de Gobierno. 
profesores que Chapuis había logrado reunir, se independiza y organiza el Colegio de Santiago. El diario El Araucano ${ }^{77}$ señala la existencia en Santiago de tres importantes colegios: el Instituto Nacional, el Colegio de Santiago y el Liceo de Chile, que junto a otras iniciativas menores como las de los profesores José Cabezón, Francio de la Puente, Germán Córdova, Martín Urrutia y Manuel Hernández, sostenían el sistema de enseñanza para alumnos de primaria y secundaria. Muchas de estas iniciativas habían adoptado para esa fecha el método Lancasteriano ${ }^{78}$ traído a Chile en 1821 por Diego Thomson. Cabe señalar aquí que en estas instituciones de enseñanza secundaria sólo el Instituto Nacional y el Colegio de Santiago impartían el ramo de dibujo, con 49 alumnos en el primero y 35 en el segundo ${ }^{79}$.

El gobierno, en materia de educación, tenía otros planes. La preocupación principal de los actores políticos era la consolidación del nuevo gobierno. El país está bajo guerra con España, que reclama la administración sobre el virreinato. Algo más de 300 años de dominio estaban en juego aquí. En pleno gobierno militar de José Miguel Carrera, vemos a De Salas como parte del grupo que redacta la constitución provisoria de $1812^{80}$.

Si bien esta etapa está despoblada de acciones académicas y artísticas, no deja de ser una etapa clave para el desarrollo del país. En medio de los trastornos propios de un cambio drástico de administración, la

77 El Araucano, 15 de enero de 1830

$78 \mathrm{El}$ sistema de enseñanza, denominado método Lancasteriano se incorporó en casi la totalidad de los países de América Latina, apenas comenzaron las independencias de los distintos países del continente. Denominado también método de enseñanza mutua, consistía en la división de los estudiantes de un establecimiento, en grupos de diez; cada grupo recibía la atención de un monitor, que era simplemente un estudiante más avanzado y de poca más edad que ejercía de instructor. De esta forma el método permitía un avance considerable en la entrega de conocimiento, con la menor cantidad de profesores responsables.

79 Labarca. Op. Cit. p. 85.

80 Salazar. Op. Cit. p. 136. 
gestión por mantener un país mínimamente en marcha, daba resultados. Es así como apenas asume el nuevo gobierno, y pese a las amenazas externas e internas (grupos aliados a las fuerzas realistas alojados en el aparato administrativo) se crea la Comisión de Educación, que tiene entre sus planes la creación de un gran centro de educación estatal que idealmente debiera reunir a la Universidad, la Academia y algunos colegios gobernados por el nuevo estado. Se trata del primer intento de control del aparato cultural por parte del gobierno naciente.

El Decreto de la Junta de Gobierno se emite prontamente y en él se hace evidente la forma lapidaria y autoritaria de poner término al antiguo régimen. En parte del decreto que incorpora la Real Universidad de San Felipe al Instituto Nacional, se lee lo siguiente:

"El Supremo Gobierno del estado, en acuerdo constitucional con el muy Ilustre Senado, trajo a la vista al concordato eclesiástico, plan de estudios y constituciones formadas por la Comisión de Educación para la organización del Instituto Nacional, civil, eclesiástico y reunión de las diversas casas de estudios de esta capital; y habiendo examinado todos los puntos que contiene, decretó en lo respectivo al Cuerpo de la Universidad, lo que transcribe a U.S. para su inteligencia:

Queda sancionado en todas sus partes el establecimiento del Museo Nacional en la Universidad de San Felipe, con todos los demás artículos y propuestas que hizo la Comisión de Educación en su informe del 22 de julio de ochocientos trece, y comisionados especialmente los sujetos que se proponen para verificar los respectivos establecimientos científicos y económicos 
con los acuerdos del tribunal o Comisión de Educación, asignaciones de fondos y ramos que se expresan en dicho informe y en las ordenanzas; a cuyo efecto se despacharán los respectivos oficios a los sujetos señalados. Que igualmente se aprueba y sanciona el plan de ordenanzas del Instituto Nacional formado el 17 de julio de 813, bajo las adiciones y correcciones que presentó la misma Comisión en 22 de julio de 813.

Lo propuesto por la Comisión, decretado, sancionado y mandado ejecutar es, a la letra, del tenor siguiente:

Como la Universidad queda incorporada al Instituto, del modo prevenido en el prólogo, será en adelante la academia de los sabios y el museo de las ciencias de que serán miembro los doctores, maestros $y$ bachilleres recibidos hasta la instalación de esta constitución; pero en adelante sólo obtendrán estos grados los que en cada profesión hayan observado el tiempo y estudio que señala la misma.(...) Se une a la Universidad, la Sociedad Filantrópica, la Academia de Práctica ${ }^{81}$, bajo sus respectivos reglamentos.

(...) En las diversas salas de la misma Universidad se deberán situar el gabinete de historia natural, para lo que se

81 El Decreto se refiere a la Academia de San Luis, como Academia de Práctica. Recordemos que el nombre "San Luis" fue puesto por Manuel de Salas en homenaje a la reina Luisa, por lo que un rápido cambio de nombre resultaba políticamente más correcto. En algunos textos la Academia es denominada también “...de Dibujo” o bien “...de Aritmética”. 
trasladará allí el principio colectado que existe en la Academia, con sus correspondientes estantes. (...) Su custodia y primera clasificación correrá al cargo de los catedráticos de Chímica (sic), Botánica y Física, bajo la inmediata inspección del virtuoso ciudadano don Manuel de Salas, promotor originario de este establecimiento." 82

Existe un movimiento político y administrativo caracterizado por la rapidez en los cambios que se implementaban y, para el caso que aquí nos ocupa, existía particularmente una premura por la puesta en vigencia de la nueva organización (inédita) de educación. Tal rapidez era, de seguro, motivada por la fragilidad del nuevo gobierno y la forma en que se gestó la nueva institucionalidad del país, lo que dejaba a los chilenos a la espera de la reacción española que tarde o temprano se dejaría caer con toda su fuerza.

Un sentimiento de orgullo y de cierto autoritarismo, se traslucía en los discursos de los gobernantes. La comunicación interna que hace llegar el gobierno -siete días después del decreto anteriormente citado- a sus órganos y reparticiones administrativas a propósito de la ceremonia de fundación del Instituto Nacional, así lo demuestra:

"Santiago y agosto 13 de 1813

El día noveno del corriente está destinado para la solemne, y pomposa instalación del Instituto Nacional. Los magistrados y cuerpo públicos que, como los más interesados en la gloria y prosperidad de la

82 Decreto de la Junta Nacional de Gobierno que incorpora la Universidad de San Felipe al Instituto Nacional. Firmado en Palacio de Gobierno: Francisco Antonio Pérez, Agustín de Eyzaguirre, Juan Egaña y José Tadeo Mancheño. Santiago de Chile, 2 de agosto de 1813. 
patria, deben concurrir á celebrar ésta función, han de presentarse en ese día á acompañar al Gobierno, y así se espera a V.S. con los individuos de su oficina á las 91/2 de la mañana en ésta sala. El Gobierno cree que ninguno faltará á un acto tan solemne, en donde la puntual concurrencia de los convidados acreditará su rol público. Dios guarde a V.S. M a S.S. Palacio de Gobierno. Agosto de 1813 Agustín de Eyzaguirre. Juan Antonio Meneses. "83 


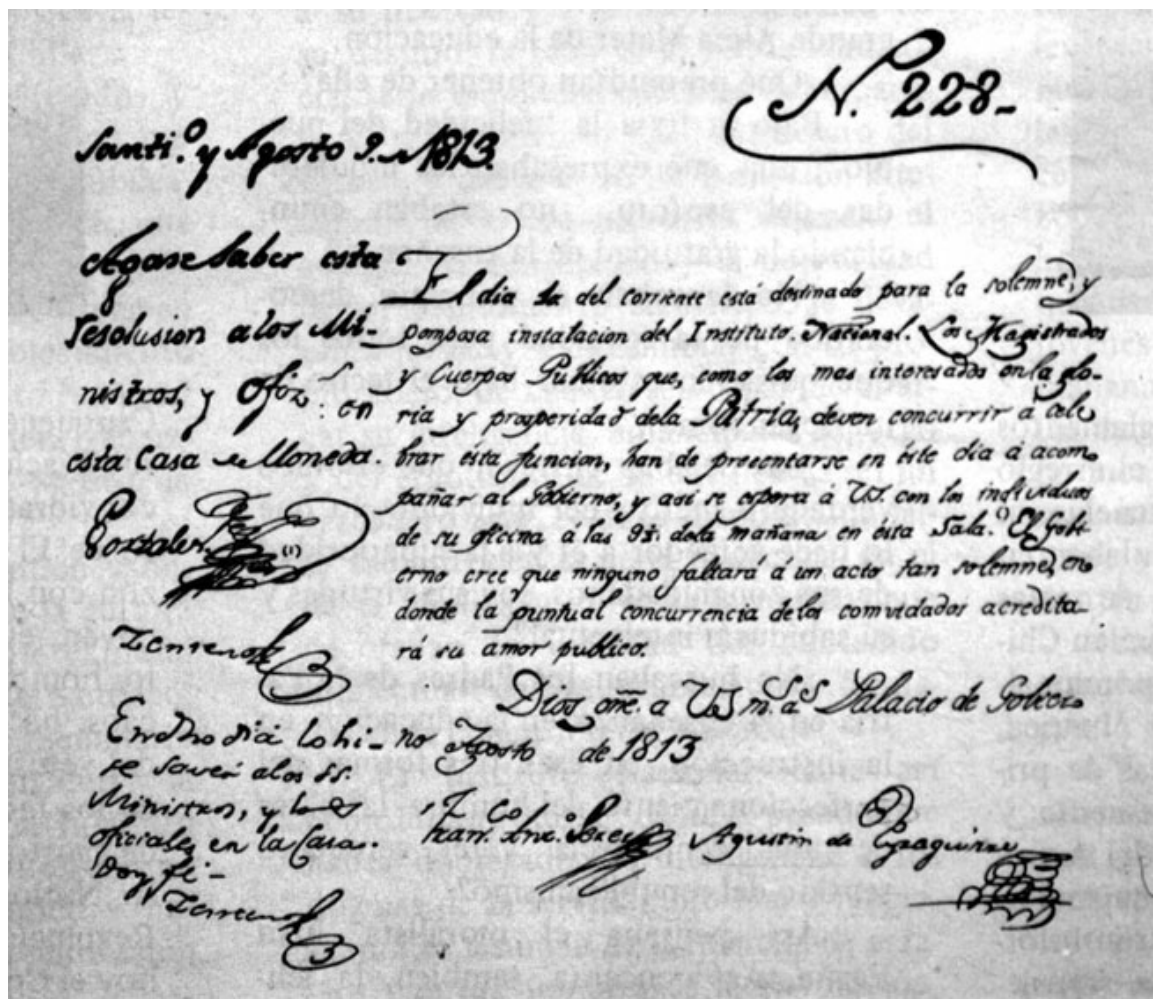

Lámina $\mathrm{N}^{\circ} 26$

Comunicación que hiciera circular el gobierno en 1813.

(Museo del Carmen de Maipú. Santiago de Chile)

Llama la atención que la nueva estructura conserva parte de la forma que tenía la Academia de San Luis, esto es: la incorporación y convivencia de materias como matemática, geometría, latín; pero también da cuenta de la aparición de otros cursos nuevos que nunca se dictaron en la Real Universidad de San Felipe, pero que sí estaban planteados por De Salas en su Academia, como son la química y la botánica. Esta "casualidad" nos permite inferir que la operación planeada por Manuel de Salas, daba resultados en orden a: 
a) Mantener la tutela sobre un sistema de enseñanza liberal, transversal, de tipo técnico-profesional.

b) Lograr una suerte de continuidad con miras a perfeccionar su plan de estudios que nunca -bajo el régimen anterior- llegó a tener el éxito al que aspiraba, en términos de orientarlo hacia los gremios de artesanos.

c) Dar vida a los cursos de ciencias que siempre pensó en implementar pero que nunca pudo levantar concretamente en la Academia.

La Academia de San Luis, en los momentos en que se incorporó al Instituto Nacional, tenía solamente 94 alumnos y se le entregaban $\$ 2.400$ al año, dineros que pasaron a formar parte del presupuesto de la nueva organización.

El siguiente curso de dibujo en Chile correrá por cuenta del Instituto Nacional, una vez disminuido el peso de la Universidad de San Felipe y absorbida la Academia de San Luis. Si la experiencia de la Academia de San Luis sirvió en algo para la creación del Instituto Nacional de Chile, fue fundamentalmente en el traspaso de las ideas que traía Manuel de Salas y las formas de aplicación de las matemáticas, la geometría, el dibujo y la química como base elemental en la formación de un ciudadano que orientara su vida hacia la práctica en sus diversas manifestaciones: la producción industrial y el arte. Nótese que en su Academia, De Salas nunca introdujo cursos de teneduría de libros, balanza, o mercadeo ${ }^{84}$.

84 Quiero decir concretamente que De Salas nunca orientó el programa de estudios de la Academia de San Luis hacia el comercio, asunto al parecer reservado exclusivamente a la aristocracia criolla. Al respecto Gabriel Salazar ubica a Manuel de Salas como un representante de la clase social que acumuló riquezas bajo distintas formas de comercio. Salazar, Op. Cit. p. 81. 


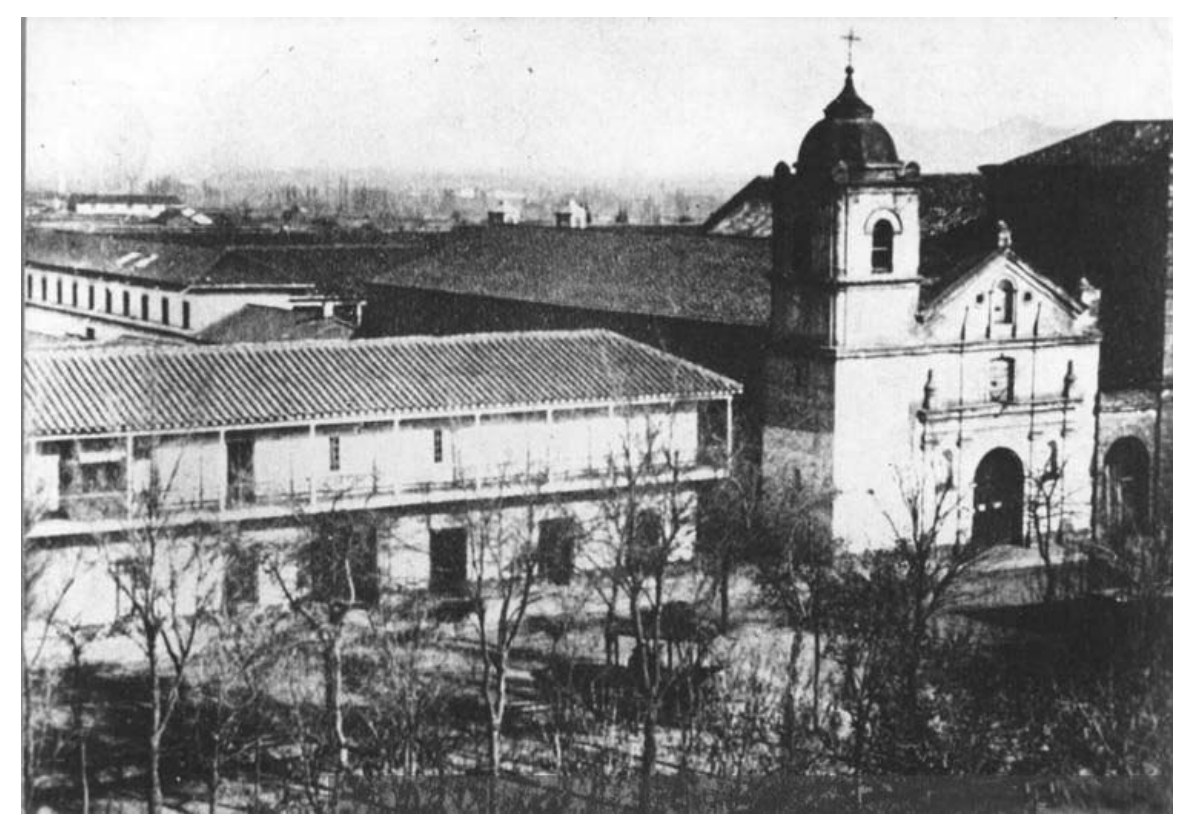

Lámina $\mathrm{N}^{\circ} 27$

Fotografía del primer recinto donde funcionó el Instituto Nacional en Santiago de Chile, año 1857.

(Biblioteca Nacional de Chile) 


\section{DESARROLLO DEL DIBUJO EN LA NUEVA REALIDAD CHILENA DEL SIGLO XIX}

Colonia, Patria Vieja, Reconquista y Patria Nueva son palabras que en Chile representan un período nunca bien comprendido, muy mal explicado y sobre el cual aún existen versiones encontradas, según las interpretaciones ideológicas o los modos de pensamiento del siglo XX. Por tal motivo seré breve al mencionar los hechos que nos permiten ubicarnos en el escenario de la Patria Vieja, es decir, del período que va desde 1810 a $1814^{1}$.

Entre 1810 y 1832 ocurrieron varios hechos que hicieron pasar al país por episodios de franco caos, desorden y crisis, producto de los acomodos de la clase política dirigente, la aristocracia, los comerciantes y los latifundistas, a la nueva estructura del país.

Al finalizar la Colonia, se inició en el país la etapa de administración independiente -La Patria Vieja- que por años fue más una fantasía que una realidad. El período se caracterizó por la inestabilidad, las luchas por el control del poder, la distribución de cuotas de poder entre las familias poderosas y la reorganización de la vida política y administrativa. Se conoce como Reconquista al período -entre 1814 y 1818- durante el cual España retoma por algunos años el control de Chile y, al mismo tiempo, los patriotas organizan el ejército libertador que bajo las órdenes de Simón Bolívar esparce la organización militar profesional por toda América del Sur y logra finalmente terminar con el dominio colonial español. Este período está caracterizado por la persecución, la implantación de una nueva imagen del rey de España, el retroceso de las formas de organización independiente y el endurecimiento de las formas de lucha por el control del territorio.

1 Es decir, el período comprendido entre la instalación de la primera Junta Nacional de Gobierno y la reconquista del poder por parte de España. 
La Patria Nueva -por último- es el resultado de la derrota de España en el control de los territorios hasta la ciudad de Temuco. Recordemos que Temuco, Osorno y Chiloé quedaron bajo el dominio de España hasta 1820.

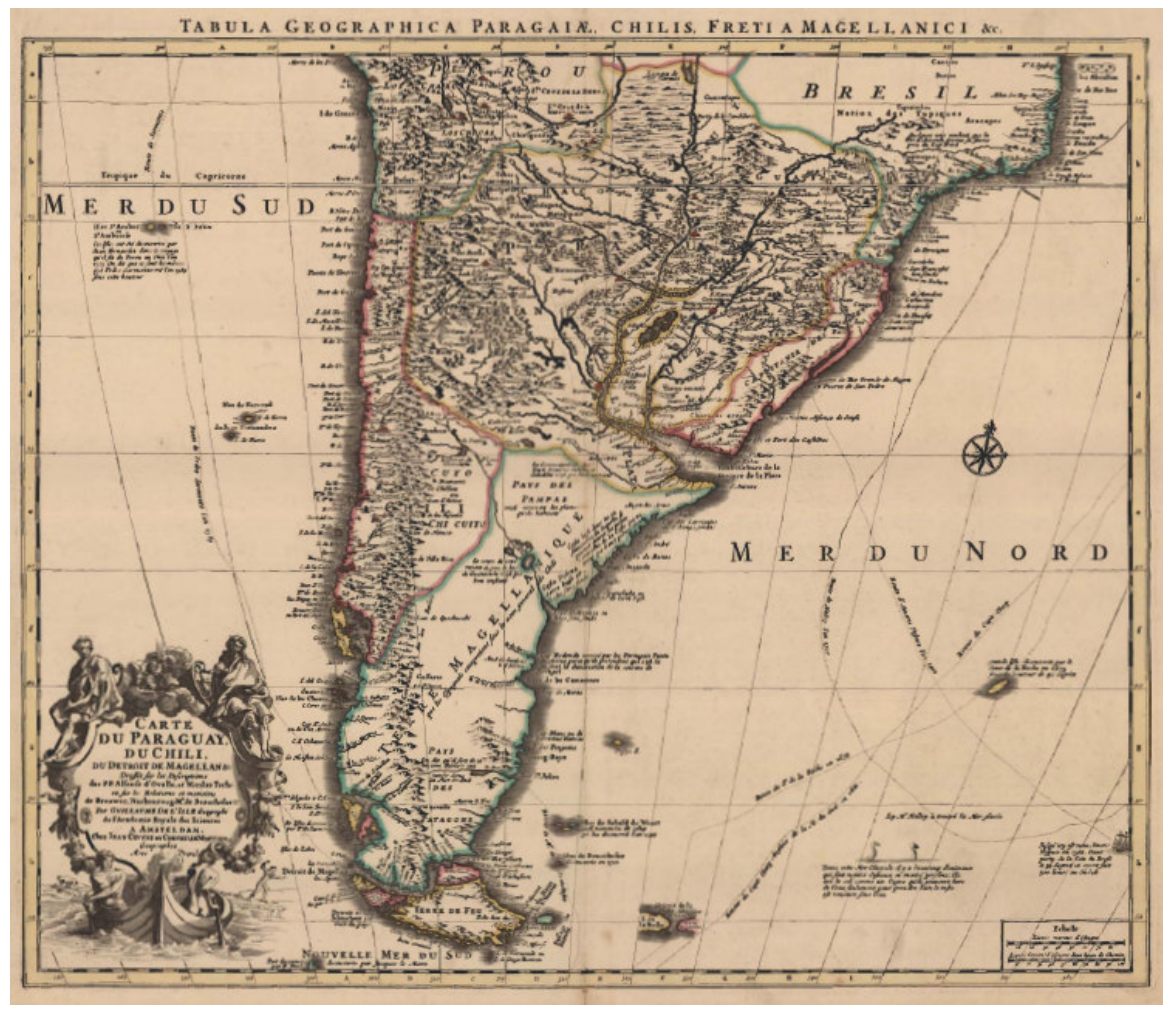

Lámina $\mathrm{N}^{\circ} 28$

Mapa de Chile en el siglo XVIII por Guillaume de L'Isle (1675-1726). En ese siglo, Chile como Capitanía comenzaba en las cercanías de Tal Tal por el norte y solamente hasta la actual ciudad de Puerto Montt. En la lámina aparece con borde rojo en el costado izquierdo que bordea el "Mer du Sud". Estas fronteras se mantendrían hasta después de 1817, fecha de la Batalla de Chacabuco, que marca la independencia militar con el Reino de España. Incluso después de esa fecha, España mantuvo el control del territorio austral de Chile hasta 1820. 
Podríamos decir entonces que es en esta última etapa cuando Chile logra organizarse realmente como república, pese a que las convulsiones internas y externas más graves (dos guerras con los vecinos Perú y Bolivia) se extenderían durante todo el siglo XIX.

Veamos pues cómo se desarrolló la enseñanza del dibujo en este nuevo escenario político y social del siglo XIX.

\section{VII.1. El Instituto Nacional y el dibujo del natural}

La creación del Instituto Nacional fue el gran logro en materia de cultura y educación (diré educación ahora, ya no sólo enseñanza) del régimen naciente. Su historia se divide en dos segmentos: el primero correspondiente a su fundación, a la cual ya nos referimos en el capítulo anterior; y el de su reorganización, que ocurre apenas España es derrotada en su intento por reconquistar Chile.

Las visiones sobre quién ideó el Instituto Nacional como concepto son múltiples y varían según las simpatías que los historiadores chilenos tienen frente a los diversos protagonistas de aquellos hechos. Juan Egaña aparece como el autor y promotor más directo de esta iniciativa ${ }^{2}$, ya que junto a José Francisco de Echaurren emitió el informe de julio de 1823 que hizo posible el nacimiento del Instituto un mes después. Otro protagonista fundamental es Manuel de Salas, sólo que interrumpe su participación en la gestión por el viaje que realiza a Uruguay en nombre del gobierno chileno y en plena guerra contra España.

2 Juan Egaña escribe en 1823 el Almanak Nacional para 1824. En la página 104 comienza a

indicar las formas de organización de la Educación e Instrucción Pública y de la existencia del superintendente y Consejo de Educación. En ese mismo documento (página 105) señala estar comisionado para la reorganización del Instituto Nacional Normal ideado el 10 de agosto de 1813. 


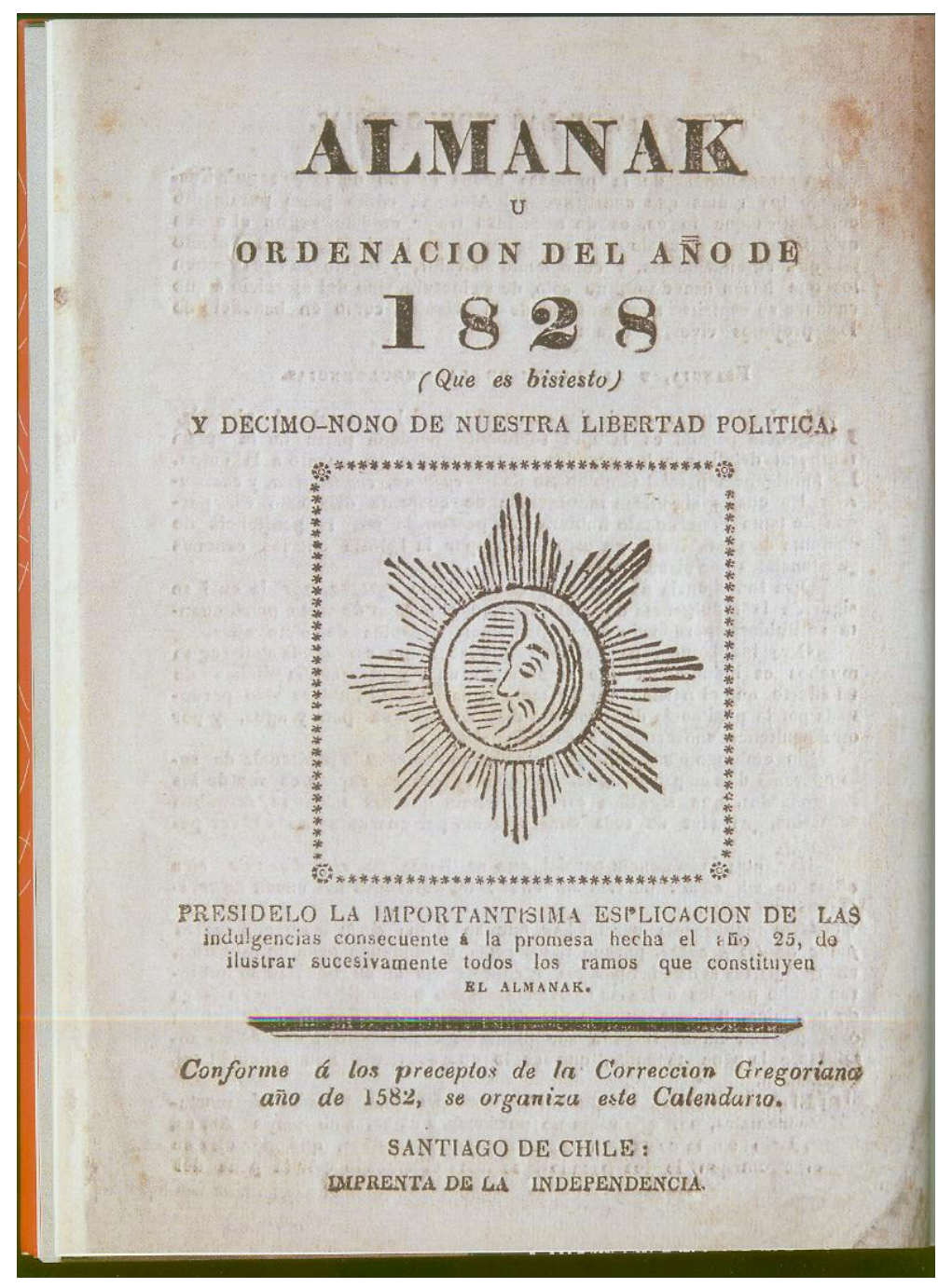

Lámina $\mathrm{N}^{\circ} 29$

Almanak. En 1823, se editó para el año siguiente, el primer texto escrito por Juan Egaña. En 1825 se oficializó la redacción de las tareas de gobierno mediante la edición sucesiva de estos textos. La ilustración corresponde a la edición de 1828.

(Biblioteca Nacional de Chile) 
El Instituto Nacional nace en el gobierno de José Miguel Carrera. La idea fue crear una estructura compleja ${ }^{3}$, tanto así que la idea de Juan Egaña en su proyecto de reorganización de 1823 contempló incluir en el Instituto Nacional una Academia de Leyes y Práctica Forense, un Jardín Botánico, un Gabinete de Historia Natural, un Laboratorio Químico, un Anfiteatro Anatómico, una Escuela de Dibujo, una Escuela de Pintura y Escultura, un Gimnasio y una Escuela Normal de enseñanza mutua. En esta estructura estaría alojada además la Academia Chilena.

Llama la atención que en la enumeración de organismos dependientes que elabora Egaña se recogen ideas como el Gabinete de Historia Natural, que ya había creado Manuel de Salas en forma rudimentaria en la Academia de San Luis, lo mismo que la Escuela de Dibujo y el Laboratorio Químico, que aunque nunca llegó a funcionar, fue creado por De Salas con motivo de la preparación de cursos asociados a la minería.

No cabe duda de que estamos ahora frente al nacimiento de la idea de lo que será -años más tarde- la Academia de Pintura y finalmente la Escuela de Bellas Artes.

El Instituto se organizó como un centro de enseñanza que reunía disciplinas de distinta índole, combinando materias de tipo científico y humanista, destinadas tanto a estudiantes de primeras letras como a estudiantes de estudios más avanzados. Si la organización inicial estuvo en manos de Manuel de Salas, su reorganización quedó a cargo de Juan Egaña.

3 El Instituto Nacional todavía existe en Chile y es conocido sólo como un liceo de hombres -el más antiguo del país- de carácter estatal y de mucho prestigio. Valga esta aclaración para señalar a continuación que el Instituto Nacional en la época a la que nos referimos en esta investigación -en 1813 y posteriormente en su reorganización en 1818- es una organización múltiple que tiende a centralizar el desarrollo de la cultura y la educación en Chile. 
La estructura, tanto del Instituto Nacional como de la futura Universidad de Chile, tendían a corresponder a las ideas de Diderot, planteadas en la Enciclopedia ${ }^{4}$. En efecto, la estructura antigua de los estudios daba un lugar preponderante al latín y a la filosofía. En ese sentido, los estudios llamados prácticos (química, física, dibujo) no tuvieron lugar en la Universidad de San Felipe, que como ya vimos ponía su acento en la filosofía, la teología y los estudios jurídicos. Como afirma muy claramente Contreras ${ }^{5}$, la misma Universidad de Chile, creada en 1848, “...no tenía aún funciones docentes; era más bien, un conjunto de cinco facultades, donde se cultivaba el conocimiento científico y humanista, al modo de las academias francesas."

Al observar la organización del Instituto en 1813 y de los cursos de dibujo, podemos observar dos rasgos detectados a partir del análisis de los documentos de la época.

a) Se mantiene la idea de un curso de dibujo asociado a la práctica de otras disciplinas ${ }^{6}$.

b) Un análisis del programa de trabajo, permite ver que la enseñanza se tiende a alejar de la idea de un dibujo que tiene como base la geometría y el estudio de sólidos, enfocándose en

\footnotetext{
4 Me he basado en el análisis acerca del impacto de la Universidad de Chile en los inicios del la república chilena, contenido en Universidad y Nación, Chile en el siglo XIX por Serrano, Sol. Ed. Universidad de Chile. Santiago de Chile. 1994.

5 Cfr. Contreras, Gonzalo, Oses, Darío y Arancibia, Eduardo. Universidad de Chile:160 años haciendo historia.

6 Gran cobertura a la instalación del Instituto da el periódico Monitor Araucano. En su edición del martes 17 agosto de 1813. Tomo 1 (56), menciona en la lista de profesores a José Gutiérrez, maestro de Dibujo.
} 
un trabajo práctico asociado a las Bellas Artes, particularmente el retrato y el paisaje.

Un documento sin fecha, pero que por el correlativo del archivo donde se encuentra, puede datarse en 1827, da cuenta de todos los profesores del Instituto junto a una reseña de las materias que imparten, a modo de plan de estudios. Particularmente ilustrativa es la página cinco del documento ${ }^{7}$ que alude a la noción de dibujo del natural. Dice el documento:

\section{Dibujo del Natural ${ }^{8}$ \\ Este curso se hace diariamente y de día para los internos y externos; se hubiera hecho también de noche desde que se hubiera hallado la lámpara necesaria; como lo previene la constitución, para los artesanos. $^{9}$}

Como se puede observar la noción de dibujo del natural, se confunde con el nombre de un curso. Se entiende por dibujo del natural a la representación de objetos, empleados como modelos. En relación a otros tipos de dibujo, veamos lo que se puede deducir de la referencia que se hace al profesor de dibujo, don Enrique Fermín. Dice el mismo documento:

7 Archivo Nacional de Chile, Fondo Varios. Vol. 801.

8 Se refiere a la Cátedra de Dibujo que se imparte en el Instituto Nacional en la fecha mencionada.

9 Se refiere al Reglamento de Artesanos redactado por Manuel de Salas en el siglo anterior y que hemos mencionado antes en esta investigación. Al nombrarse a internos y externos, se hace alusión a que el Instituto Nacional tenía régimen de internado tanto para profesores, como para estudiantes. "Vivir en la calle" equivalía entonces a ser externo al Instituto, es decir, al hecho de no vivir en sus dependencias. 
"De toda exactitud y buena voluntad. Muy pacífico. Vive en la calle por tener que ocuparse de hacer retratos y paisajes." 10

Encontramos entonces tres tipos de dibujo que podríamos traducir al término actual como:

a) Dibujo de objetos. Curso que a juzgar por los profesores que habían y la herencia de la Academia de San Luis debió tener una fuerte carga de estructura, perspectiva y geometría.

b) Dibujo de paisaje, asociado fuertemente a las Bellas Artes y con herencia clara de la "pintura a la romana" ejecutada hacia fines del siglo XVIII y comienzos del XIX.

c) Dibujo de retrato, que obviamente debió tener la influencia tardía de la escuela cusqueña y las actualizaciones estilísticas que comenzaban a operar de la mano del trabajo de pintores como José Gil de Castro.

El 16 de mayo de 1828, el Rector, Juan Francisco Meneses, emite un informe acerca de la plantilla de profesores, sus categorías y sueldos. Nótese que las materias que se imparten equivalen a la mezcla perfecta entre la Universidad de San Felipe y la Academia de Dibujo, salvo que aún en esta fecha no se incluyen botánica, química, ni geometría:

\section{"Instituto Nacional. Nómina de su profesorado y cátedras que enseñan: \\ Rector Juan Francisco Meneses 1000 pesos anuales $^{11}$}

Vice-rector Blas Reyes. 600 pesos

10 "vivir en la calle" equivalía a ser externo al Instituto, es decir, el hecho de no vivir en sus dependencias físicas.

11 La renta que se registra en este informe corresponde a la que recibía en 1813, es decir durante la Patria Vieja; para subvencionar dicha remuneración, se le asigna un ayudante en 1828, con un sueldo de 390 pesos anuales. 
Inspector de Manteístas: José María Fernández, 400 pesos.

Catedrático de Derecho Canónico y Civil: Eusebio Sepúlveda. 500 pesos.

Catedrático de Derecho Natural y de Gentes. José Santiago Iñiguez, 500 pesos.

Catedrático de Teología. Manuel Carrasco. 500 pesos.

Catedrático de Filosofía. José Miguel Baras (sic) 500 pesos.

Catedrático de Mayoristas, de Gramática latina. José Gregorio Echagüe. 500 pesos.

Catedrático de Minoristas. Pedro Fernández Garfias. 500 pesos.

Catedrático de Idioma francés y de elocuencia: Buenaventura Marín, 250 pesos por cada cátedra.

Catedrático de Idioma inglés. Juan García. 250 pesos.

Primer Catedrático de Matemáticas. Andrés Gorbea. 500 pesos. ${ }^{12}$

Segundo Catedrático de Matemáticas. Antonio Gatica $\$ 400$ pesos.

Catedrático de Primeras Letras (método de enseñanza mutua) Juan Solano Pérez. 500 pesos.

Maestro de Dibujo. Vacante desde el primero de mayo de 1828 en que se separó al Sr. Enrique Fermin ${ }^{13}$. Sueldo (para el cargo). 500 pesos.

12 Quince años más tarde, veremos a este catedrático como Director del Museo Nacional, dependiente del Instituto Nacional.

13 En otros documentos de la época se le menciona como Enrique Jennin. 
Catedrático jubilado de Elocuencia. Juan

Egaña. 500 pesos."14

El documento menciona además a tres inspectores, un mayordomo, un abogado y un procurador. Sin embargo, lo relevante de esta nómina lo constituyen tres hechos:

a) Que en 1828 no había en Chile un curso de dibujo en plenas funciones.

b) Que el profesor de dibujo no era considerado catedrático, sino sólo maestro, categoría asignada a los profesores de los gremios de artífices, tal como ocurría en el siglo anterior ${ }^{15}$.

c) Que la mayor falta de continuidad -a estas alturas- la tenía el curso de dibujo, que contaba en Chile a esta fecha sólo con 4 profesores: Petri y Fernández Arrabal, en la Academia de San Luis; José Gutiérrez en el Instituto Nacional en su etapa de fundación; y Enrique Fermín en el Instituto Nacional en etapa de reorganización.

El que se denomine Dibujo del Natural al curso de Enrique Fermín (o Jennin) nos indica una sola cosa: que los estudios de dibujo se basaban en las fórmulas de Manuel de Salas respecto a una asociación entre dibujo con modelos y aplicaciones de las nociones de geometría. Sin embargo, la aparición del retrato y el paisaje, en ese mismo maestro, nos señala una aproximación nunca antes vista a la enseñanza del dibujo con una aplicación directa a las Bellas Artes. Lamentablemente el alejamiento de Fermín en 1828 deja inconcluso el desarrollo de esta materia.

14 Instituto Nacional, Apuntes sobre su profesorado. Archivo Nacional de Chile, Fondo Varios. Vol. 801.

15 Recordemos tan sólo a los maestros mayores, de los gremios de artesanos. 
Esta aseveración nos permite concluir con certeza que la influencia del modelo de Manuel de Salas se aplica en la estructuración de cursos de dibujo en Chile con orientación hacia las Bellas Artes propiamente tales con la implantación del Instituto Nacional y sólo entre 1823 y 1828.

\section{VII.2. La enseñanza del dibujo en Chile después de 1828}

En 1828 comprobamos que no existen indicios de cursos de dibujo en Chile. El escenario de la enseñanza del dibujo (y otras materias por supuesto) en el Chile republicano, particularmente en la Patria Nueva y en ese año en especial, cambió radicalmente en relación a lo que ocurría durante la colonia, en el siglo anterior.

Chile estaba convulsionado, era urgente el reestablecimiento del poder de las instituciones. Poco a poco, el nuevo gobierno, después de la derrota definitiva de España, logró tomar el control administrativo del país.

Si hasta 1810 el país se veía "ordenado", silencioso y con una vida que transcurría en los interiores de casas e instituciones, el siglo XIX comenzó a ocupar espacios más públicos ${ }^{16}$. Esto

16 Sabemos que hubo prácticas cotidianas que comenzaron a desarrollarse más colectivamente, como es el caso del lavado de ropa, la búsqueda y compra del agua, la misa, etc. Durante la colonia, en cambio, las manifestaciones públicas eran bastante pocas y se limitaban a los castigos que aplicaba el tribunal de la Santa Inquisición en las plazas públicas, y a la actividad en las ramadas y chinganas (locales públicos de precaria edificación, generalmente ubicados en las márgenes de la ciudad y que tuvieron su origen en la celebración de Pascua, Cuaresma y Corpus Cristi). En el siglo XIX y probablemente con el fin del control español, se produjo un relajo en las costumbres de la ciudad. En 1818, y luego en 1824, se dictan leyes y decretos que prohíben y regulan la existencia de ramadas y chinganas, pues alteraban el orden público. Respecto a este 
generó que algunas prácticas más privadas comenzaran entonces a ser compartidas. Un desarrollo evidente se percibió en la música, el teatro y las Bellas Artes, que comenzaron a difundirse, a masificarse, naturalmente en la escala de producciones que era posible en un país pequeño, pobre y sumido en la confusión post colonial. La enseñanza a nivel nacional comenzó a ser ordenada y con visos de una planificación nunca antes observada ${ }^{17}$.

La sociabilidad generó un fenómeno particular, que aunque iniciado en el siglo XVIII, se extendió en el siguiente. Se trata de las tertulias. Famosas fueron las que tenía lugar en casa de Isidora Zegers ${ }^{18}$. A ellas concurría una buena parte de los artistas e intelectuales de la época. Mauricio Rugendas y Andrés Bello, futuro rector de la Universidad de Chile, fueron algunos de ellos.

Los efectos del pensamiento de la Ilustración y el interés por conocer este apartado lugar del mundo, provocaron la llegada a Chile de naturalistas y científicos que a principios del siglo XIX se asentaron en diversas zonas del territorio nacional. Por esa misma fecha llegaban a Chile Claudio Gay e Ignacio Domeyko,

tema, se puede consultar a Porcell, Fernando en su libro Diversiones y Juegos

Populares.(Ediciones DIBAM, Santiago de Chile, 2000)

17 En octubre de 1825 aparece el primer periódico dedicado a la educación, El Redactor de la

Educación, dirigido por el rector del Instituto Nacional, Carlos Ambrosio Dossier, ingeniero francés que propició grandes reformas en el sistema de enseñanza chileno. Junto al periódico mencionado, proyectó una biblioteca, un observatorio astronómico, un gabinete de física, química e historia natural y generó cambios en el reglamento de castigos de los estudiantes, reemplazando los azotes por estímulos morales y consejos.

18 Isidora Zegers (Madrid 1803 - Santiago de Chile 1869) llegó a Chile en 1823 y fue activa integrante de la intelectualidad chilena. Participó en la creación de la Sociedad Filarmónica en 1827 y en la fundación del Conservatorio Nacional de Música en 1852. Sus amistades incluían a músicos, juristas, pintores y dibujantes de la época. 
naturalistas que se destacaron por el uso del dibujo en sus investigaciones. Ellos comenzaron a integrarse a grupos intelectuales nacionales como el de la señora Zegers, generando elites asociadas al pensamiento más avanzado.

No obstante, una clara diferenciación se tejió entre los dibujantes y quienes enseñaban el dibujo. Los primeros se adhirieron al grupo donde se concentraban los protagonistas de las manifestaciones artísticas, como la música, el canto, el teatro y la pintura. En ese grupo se combinó la participación de intelectuales, escritores y algunos políticos, y también de los científicos y artistas extranjeros antes mencionados.

Los profesores de dibujo, en tanto, se mezclaron con el conjunto de profesores de distintas disciplinas, generalmente asociados a diferentes formas de producción de bienes. Recordemos que la Casa de Moneda, a fines del siglo XVIII, generaba bastante empleo a talladores, dibujantes, grabadores y a una gama de oficios asociados, como químicos, fundidores, prensistas, vaciadores, etc. Sin ir más lejos, recordemos que Ignacio Fernández Arrabal, profesor de dibujo de la Academia de San Luis, ejerció a fines del siglo XVIII como dibujante y tallador de matrices de moneda, en la Real Casa de Moneda en Santiago. Esa formación, dada por la práctica en la producción de diversos bienes de consumo, generó la distancia con respecto a los dibujantes-artistas, escasos en el siglo XVIII y más abundantes en el siglo siguiente. En los inicios del siglo XIX, vemos al maestro Fernández Arrabal como profesor de dibujo del Instituto Nacional.

Esto permitió que hoy, por los documentos de la época, podamos saber que las categorías y disciplinas cercanas al dibujo, se asociaban a pintores, escultores, grabadores (asociados a la estampa y la ilustración científica), talladores y arquitectos. De hecho, la clasificación laboral de "dibujante" no 
se registra en ningún documento anterior a 1820. Podemos constatar hoy que la distinción actual, que nos parece tan "natural", entre arquitectos, artistas y artesanos, no era entonces tan clara ni diferenciadora. Sólo que los artistas tenían una fuerte vinculación a la clase cultural acomodada.

\section{VII.3. Creación de la Academia de Pintura}

Tal como señalé al describir los detalles de la constitución del Instituto Nacional de Chile, su origen está marcado por una suerte de semejanza con la iniciativa francesa del siglo XVIII, el Collège. Esto implicaba la sumatoria de diversos organismos públicos destinados al desarrollo de la ciencia y las humanidades, en sus diversas formas: la producción, la enseñanza, la creación, la investigación; en otras palabras, el desarrollo de la cultura en el nuevo escenario de la Patria Nueva. Sólo la fundación de la Universidad de Chile el 17 de septiembre de 1843 viene a definir la estructura de la educación chilena, dejando el conocimiento universitario, más diversificado ahora que en la anterior Universidad Real, en manos de un ente estatal de enseñanza superior, y la enseñanza secundaria y técnica en el Instituto Nacional, también estatal.

Pero para el nuevo gobierno era necesario sumar a los demás organismos, una Academia de Pintura, que a juicio de las autoridades permitiría el florecimiento de las Bellas Artes en el país.

La idea de una academia de pintura tuvo un curioso origen. Un informe emitido en 1832 por Manuel Montt, Ventura Marín y Juan Godoy contenía un plan de estudios humanistas para estudiantes del Instituto Nacional, tal vez el primero estructurado en Chile de manera orgánica, que incluía latín, geometría, aritmética, castellano, inglés, francés, trigonometría 
rectilínea, historia civil, griego y filosofía, mas no dibujo, que hasta 1828 sí se enseñaba, como ya se señaló, en el Instituto Nacional. En otras palabras, la propuesta fue una excelente mezcla entre una academia y un liceo público que vendría a reforzar las actividades del Instituto Nacional ya en plena actividad, otorgando como un valor agregado, metodologías nuevas a la noción de enseñanza pública. El hecho de eliminar el curso de dibujo en la nueva estructura, generó por defecto, la necesidad de otorgarle un espacio propio a esta disciplina, acercándola a las Bellas Artes, por la vía de la pintura. Fue así como al madurar la idea bajo el gobierno de Manuel Bulnes, se creó la Academia de Pintura, siendo entonces Salvador Sanfuentes el ministro de instrucción pública.

Para ese efecto, y como un primer intento, el gobierno chileno invitó al pintor francés Raymond Monvoisin a crear dicha academia. Monvoisin llega a Chile en enero de 1843 y luego de 14 años regresa a Francia, sin concretar definitivamente el proyecto por el cual se estableció en Chile. Entre las muchas causas que se asocian al incumplimiento, se encuentra la idea de que este pintor no portaba precisamente los ideales del modelo francés que se trataba de imponer; otras causas se asocian a su mayor interés por el trabajo de retratista y paisajista por encargos, lo que le llevó a acumular alguna pequeña suma de dinero que le permitía sin muchos esfuerzos un buen pasar en esta tierra. De esta forma pasaron los años y la idea de una academia de pintura se fue postergando, más aún cuando Chile y su gobierno se encontraban concentrados en los problemas con los países limítrofes.

En el intertanto, nuevas ideas se irían acumulando, las cuales hicieron posible concretar la idea. Manuel Bulnes Prieto -presidente de la república- emite por fin el decreto que crea la 
Academia de Pintura, el 4 de enero de $1847^{19}$, es decir, 21 años después de la fecha en que desaparece de los registros el profesor Fermín del Instituto Nacional y cuatro años después de la llegada de Monvoisin. Llama la atención que en marzo de ese mismo año se crea la Escuela de Artes y Oficios.

La nueva Academia de Pintura funcionó bajo el alero del Instituto primero y luego de la Universidad de Chile.

No es coincidencia que la omisión y carencia de un curso de dibujo en el plan propuesto por M. Montt, V. Marín y J. Godoy diera pie luego a que el oficio o decreto que crea la Academia de Pintura, centrara su interés en el dibujo. Para efectos de este estudio, debo subrayar lo que ya dije: no se trata de una coincidencia. El plan contemplaba para el dibujo un lugar más destacado. El dibujo fue propuesto como la base de la enseñanza de Bellas Artes, no en su decreto de creación sino en el reglamento incluido en dicho decreto, que señala lo siguiente ${ }^{20}$ :

“Capítulo 1.

Objeto de la Academia

Art. $N^{o}$ 1. En la Academia de Pintura de Santiago se suministrará la enseñanza elemental del dibujo, para servir de introducción a todos los ramos de artes que suponen su conocimiento. Más su principal objeto es un curso completo de pintura histórica, para los alumnos de número de la Academia.

19 La Academia de Pintura sólo comienza sus actividades con la inauguración oficial ocurrida en mayo de 1849.

20 Publicado en Anales de la Universidad de Chile, correspondiente al año de 1849. Primera sección, Decretos del Gobierno. Santiago de Chile, enero 4 de 1849. Biblioteca Nacional de Chile. 
Art. $N^{o}$ 2. El curso principal de la Academia constará de las siguientes clases: $1^{a}$ de dibujo elemental a la estampa, dividida en tres secciones. La $1^{a}$ sección, estudiará principios y cabezas; la $2^{a}$ extremidades; la $3^{a}$ la figura entera. La $2^{a}$ clase pertenecerá a la imitación del relieve o estatuas, $i$ tendrá las mismas secciones que la anterior. La $3^{a}$ completará el curso de dibujo para la composición histórica, por medio de la imitación del modelo vivo, de un curso de anatomía práctica i otro de pintura i ropajes al natural."

Como se puede ver en este documento, el protagonismo lo tiene el dibujo, no la pintura.

La Academia de Pintura tenía alumnos regulares y alumnos supernumerarios $^{21}$. Los cursos para éstos últimos se dirigían a quienes "...quieran estudiar el dibujo por afición o para dedicarse a otros ramos..." Claramente preparaba a alumnos que no tenían por vocación el arte, sino otras materias asociadas a los gremios de artesanos, que en buenas cuentas eran los que tenían el mismo perfil de los alumnos de la antigua Academia de San Luis, 60 años antes. Al crearse la Escuela de Artes y Oficios, los cursos para los alumnos supernumerarios de la Academia pasaron a ser preparatorios para la Escuela de Artes y Oficios.

La inauguración de la Escuela de Artes y oficios, en marzo de 1847 , formó parte de una escalada de innovaciones que tuvo al dibujo como centro. En esta oportunidad la naciente escuela era el espacio, propiamente tal, destinado a la formación de 
artesanos. La Academia de Pintura, en cambio, sería el espacio destinado únicamente a las Bellas Artes, contratándose para su dirección al pintor italiano Alejandro Ciccarelli ${ }^{22}$. Se marca aquí, definitivamente la separación entre la noción de Bellas Artes y la de artesanía.

Un hecho curioso viene dándose, no obstante, desde 1845 en Santiago de Chile. En una sala del Convento de San Agustín en pleno centro de la ciudad, el profesor Luis Prieto comenzó a dictar clases de dibujo, según el método del arquitecto A. Bouillon denominado Principios de Dibujo Lineal ${ }^{23}$. La escuela, denominada precisamente Escuela de Dibujo Lineal pero rápidamente conocida como la escuela de la Cofradía del Santo Sepulcro, se trasladó luego a una sala de la Iglesia de San Francisco y llegó a reunir a cerca de medio centenar de alumnos. Un curioso decreto de 1843 eximía de la milicia a quienes estudiaran dibujo lineal, razón por la cual el ejército se opuso a las clases del profesor Prieto y poco a poco la escuela comenzó a declinar. En su momento, esta escuela no hizo más que asumir la enseñanza del dibujo como disciplina básica para el ejercicio de un oficio en el gremio de artesanos. Este gremio arrastraba una estructura administrativa proveniente de la colonia y no tenía amparo en el aparato estatal republicano, por lo que la iniciativa privada del profesor Prieto resolvía un problema al gobierno y llenaba un vacío en la formación elemental de los artesanos; esa fue la causa de la existencia de tal decreto.

22 El 18 de julio de 1848 Ciccarelli firma en Brasil su contrato para venir a Chile a hacerse cargo de la Academia de Pintura. Ciccarelli estaba contratado por el entonces rey de Brasil Pedro II para enseñar a su esposa María Teresa, como profesor particular de pintura. Será el Cónsul de Chile en Río de Janeiro, señor Hochkolf, quien gestione su viaje a Chile.

23 Edición en español a cargo de Pascual Hernández, Imprenta Guillot y Julián, Paris. 54 páginas. (s.f.) 


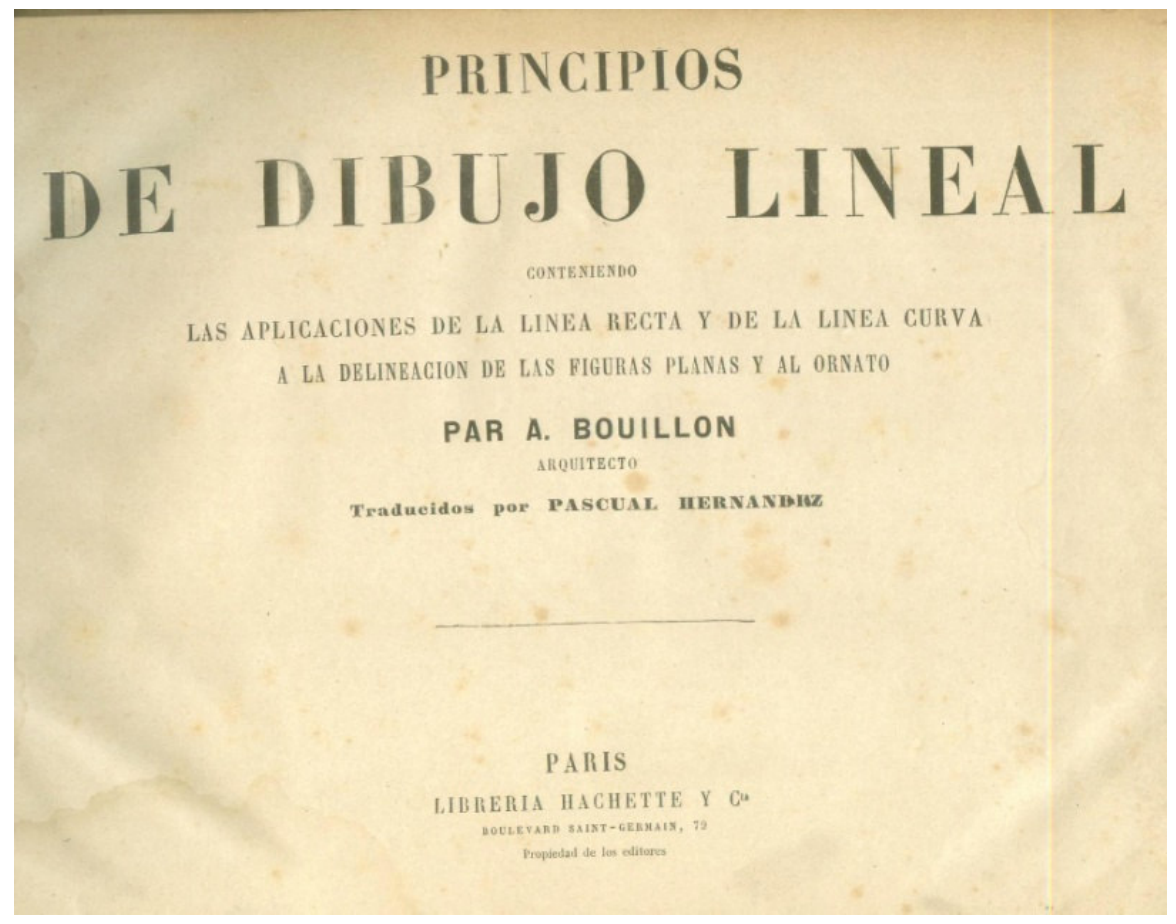

Lámina $\mathrm{N}^{\circ} 30$

Principios de Dibujo Lineal del arquitecto A. Bouillon, traducido por Pascual Hernández (París, Hachette, s.f.). Empleado en Chile en los cursos de dibujo del profesor Prieto, en la Cofradía del Santo Sepulcro.

Con una fuerte arremetida, el profesor Prieto no cierra su escuela y extiende sus actividades con intenciones de incorporar música y canto, pretendiendo fundar además una escuela con esas disciplinas, hecho que no ocurrió. Finalmente la Escuela de Dibujo Lineal de la Cofradía del Santo Sepulcro establece una alianza con la escuela de ornamentación en 1854, que daría pie después a la creación del curso de escultura dirigido por Augusto Francois. 
En efecto, el 17 de noviembre de 1850 se crea el curso de arquitectura $^{24}$, en 1854 el de ornamentación y el 30 de agosto de 1858, el curso de escultura ya mencionado, con Augusto Francois a la cabeza. Ese mismo año, estas cuatro materias que en algún momento se reunieron bajo el nombre de "Sección de Bellas de Artes" del Instituto Nacional, mantiene su nombre pero pasa a depender de la Universidad de Chile. Esta nueva agrupación, reemplaza la administración de la Academia de Pintura que mantiene su estructura. En la práctica, y tal como ya señalé en I.2.2., es la primera Academia de Bellas Artes en Chile

Sin embargo, un nuevo decreto, del 7 de enero de 1859, divide el curso de escultura en dos partes, denominándose una como estatuaria y la otra como escultura ornamental. Esa fue la última modificación legal que hizo el gobierno de Chile para consolidar la partida formal de la enseñanza de las Bellas Artes en general y del dibujo, la pintura y la escultura en particular.

En medio de estos decretos de gobierno, el desarrollo del dibujo estaba claramente definido. La Escuela de Artes y Oficios incorporó un dibujo orientado a la formación de técnicos (torneros y hojalateros), trabajando en forma conjunta un dibujo del natural y un dibujo técnico. El curso de arquitectura consideró el dibujo como lenguaje entendido como boceto y dibujo técnico. Finalmente los cursos de escultura y pintura desarrollaron el dibujo como una disciplina básica para apoyar la formación del artista escultor y pintor respectivamente. En estos cursos el dibujo se realizó fundamentalmente a base de modelos objetos, yesos de figuras humanas y modelos vivos de figura humana, lo que sentó las bases del sistema de trabajo que continúa con mayores o menores cambios, hasta el día de hoy, en donde el dibujo desempeña un rol asistencial o de apoyo para

24 Dirigida por el arquitecto francés Claude Brunet des Baines. 
otras disciplinas. No será sino hasta 1891, que se crea en Chile la Escuela de Bellas Artes en la Universidad de Chile. 



\section{CONCLUSIONES}

Muchas de las conclusiones de esta investigación, ya pueden visualizarse en el cuerpo mismo de este trabajo. Por esa causa, este capítulo posee también el carácter de resumen y es la razón por la cual parece más pertinente entenderlo como una síntesis conclusiva.

Queda claro que las causas que desarrollan el proceso de estructuración de la institucionalidad para la enseñanza en Chile, comienza en la colonia con un fuerte respaldo de la Iglesia Católica, alcanzando alguna complejidad a fines del siglo XVIII, para continuar en el segundo decenio del siglo XIX con una planificación gubernamental cívicomilitar propia (chilena) y con clara influencia de la Ilustración. Es en ese periodo de 30 años que aparece la figura de Manuel de Salas a quien señalo tajantemente como el principal gestor de la enseñanza del dibujo en Chile. Pero, no es todo: Manuel de Salas ejecutó para Chile importantes aportes que modificaron el proceso de enseñanza/aprendizaje en todos sus niveles. ¿Por qué ahora planteo la relación de dos palabras, como contenidas en el sistema de educación chilena en los inicios del siglo XIX en Chile?

Pues bien, Manuel de Salas ejecutó cambios en las metodologías de enseñanza, incorporando la noción de curso regular dentro de un programa, es decir que las materias no dependían de las ideas de un profesor, sino que estaban establecidas en un programa mayor y poseían un objetivo más allá de la propia sala de clases. Los modos de entregar la materia, estaban en directa relación con lo que interesaba que el alumno aprendiera. De Salas entendió el proceso como algo dinámico y no sólo en una determinada dirección. Según esta idea, la suma de materias -fundamentalmente prácticas- daría por resultado un sujeto apto para realizar oficios, una institución otorgaría la certificación correspondiente. Este simple paso genera un cambio de paradigma en un proceso que hasta esa fecha era estrictamente vertical y se centraba en la enseñanza, es decir la entrega de información. 
Sin embargo y siguiendo el pensamiento de Manuel de Salas se puede concluir que la creación e incorporación de un curso de dibujo, tiene en su base, un carácter y objetivo destinado al perfeccionamiento de los miembros de los gremios de artesanos. Este componente resulta muy concordante tanto con la clase social de la que proviene Manuel de Salas, como de su actividad mercantil. No se debe dejar de lado que de Salas ejerció como síndico del Tribunal del Consulado ${ }^{25}$ y desde ese puesto ejerció parte del control administrativo de la colonia en materias de mercadeo, donde amasó su pequeña fortuna. Sin ir más lejos, su más cercano amigo y luego pariente político, el magnate José Antonio Rojas, fue un destacado industrial minero, por lo que es muy factible que el conocimiento adquirido por Manuel de Salas en materias propias de la minería, hayan tenido esa fuente. Buenas razones financieras y muy personales tenía De Salas, como para generar estrategias que mejoraran la mano de obra en la precaria industria de la época (principalmente minera) y en los magníficos negocios de compra y venta de materia prima.

Sostengo además que Manuel de Salas tuvo una motivación personal por el dibujo dado que de joven y junto a sus lecturas que comprenden textos de matemáticas, literatura, ciencias, geometría, pintura y dibujo, también pinta y dibuja ${ }^{26}$.

Los aportes de Manuel de Salas se pueden dividir en dos áreas: el dibujo y la enseñanza. Será entonces alrededor de ellas que se organizan a continuación las conclusiones más relevantes de esta investigación.

No obstante lo anterior, las conclusiones serán planteadas en orden a despejar primero un asunto epistemológico previo y más amplio

25 Cargo público equivalente a una actual Cámara de Comercio

26 "Estoy aprendiendo a dibujar, creo que cuando venga Vm, ya pintaré, y así traiga de aquellos colores que aquí no se hallan, como arcorsa de grano, carmín superfino de Florencia, etc., y buenas estampas". Carta de Manuel de Salas a su amigo José Antonio Rojas, ya citada. Lima, febrero de 1772. En Salas E., J. Op. Cit., p.111. 
asociado a los mitos fundacionales y errores históricos en el marco de la investigación aquí desarrollada:

\section{VIII.1. Respecto a los mitos fundacionales: confusiones y errores históricos sobre el origen de las Bellas Artes y el dibujo en Chile, y la influencia extranjera}

En el terreno de la cultura del siglo XVIII e inicios del XIX, en Chile la investigación histórica y teórica se ha dedicado bastante al estudio de las causas políticas de la independencia de Chile con España; se ha dedicado también con esmero al estudio de las formas de desarrollo de manifestaciones culturales en general, como el teatro, la música y la literatura; y al estudio de las actividades sociales, como las tertulias, las misas, los paseos y los juegos. Lo planteaba ya en el comienzo de esta investigación $^{27}$ : la existencia de mitos y errores históricos acerca del origen y desarrollo de las Bellas Artes en general y el dibujo en particular en Chile, ha generado reiteradas imprecisiones y confusiones acerca de los hechos y sus contenidos. Será bueno ahora enumerar cuatro de dichas imprecisiones, confusiones y mitos, y plantear a modo conclusivo la rectificación.

27 Remito al lector a los puntos I.1.1 y I.1.2 de esta investigación. 


\section{VIII.1.1. Arte y artesanía}

La literatura colonial y del primer periodo republicano chileno no se refiere al "arte", tampoco a la "artesanía", como conceptos diferentes, ni distingue entre artesano y artista. Las investigaciones del siglo XIX y las más recientes del siglo XXI, tampoco han aportado a aclarar este punto. El único autor (historiador) que analizó esa materia -sin profundizara mediados del silgo XX, fue Eugenio Pereira Salas en los documentos ya referidos en esta investigación. Tal vez el origen de esta carencia se aloja en el hecho que la palabra "arte" se ha aplicado habitualmente al siglo $\mathrm{XX}$, XIX y anteriores, sin distinciones epistemológicas severas, dándose por hecho que se trata de la misma actividad o bien se trata de un concepto que alude siempre a las mismas actividades. Obviamente es un error utilizar la palabra "arte" bajo la concepción más contemporánea que la acerca a "artes plásticas" y más aún a "artes visuales" para referirse a las manifestaciones disciplinares y sus usos -asociados al conocimiento- (escultura, ornamentación, pintura, dibujo, arquitectura, artes y oficios o artesanía) desarrollados en la colonia, particularmente en los siglos anteriores al XIX. En ese contexto de ideas, efectivamente las manifestaciones visuales más concordantes con nuestro uso actual de la palabra "arte" se comienza a dar solamente a partir del siglo XIX y, concretamente a partir del uso de la palabra Bellas Artes, empleada en Chile por primera vez en el informe de Montt, Marín y Godoy de 1832, ya referido en VII.3 en esta investigación.

Hasta 1828, momento en que se terminó de enseñar dibujo en el Instituto Nacional, el concepto "dibujo" 
se empleaba significando una base genérica de conocimientos visuales y adiestramiento motriz tanto para estudiantes en general, artesanos y artistas, alarifes y trazadores. "Pintura", en cambio, cuando se crea el curso de pintura en el Instituto Nacional, comienza a ser, sin nombrarse, sinónimo de Bellas Artes como al poco tiempo después lo fue la palabra "escultura". Esa es la confusión: lingüísticamente puedo asociar el error a la operación de considerar una parte por el total. Aquí una disciplina es sinónimo de un conocimiento. Esa es la causa por la cual se ha creado la falsa idea de que en Chile las Bellas Artes o el "arte", nació recién en 1847 con la creación de la Academia de Pintura. Lo que sí es correcto señalar, que la noción de Bellas Artes, al modo en que manejamos como concepto actualmente, si comienza a ser similar en esa fecha. 


\section{VIII.1.2. La "influencia" francesa}

Se habla habitualmente de un modelo francés del siglo XVIII $^{28}$ para el arte, importado a Chile en el siglo siguiente. Esa aseveración habitual en los libros de historia del arte chileno y que se repite a diario en los cursos de esa materia en las escuelas de arte en Chile, desconoce la proveniencia del conjunto de ideas que llegaron a Chile de la mano de las ideas de la Revolución Francesa y la Ilustración. En nuestro medio, la influencia francesa operó solamente en la segunda mitad del siglo XIX. En el momento de la creación de la Academia de Pintura, las ideas que habían movilizado a Chile en la primera mita del siglo XIX provenían de las fórmulas teóricas que orientaban la Ilustración, que si bien en su origen eran francesas, llegaban a Chile desde España, no de Francia. En esta aseveración no puedo desconocer que Mariano Egaña (ver VIII.1) se encontraba en Francia en el momento en que invita a Monvoisin a establecerse en Chile Sin ir más lejos, la labor de este pintor en Chile, no pasó de ser un trabajo personal centrado en el retrato y el paisaje y nunca fue incluido en la Academia de Pintura, siendo un italiano su primer director.

28 En 2000 La Municipalidad de la comuna de Las Condes en Chile, edita un catálogo denominado La Academia de Pintura, en el documento se puede leer: “...esta Academia (refiere a la Academia de Pintura chilena) fue una copia del modelo institucional francés y por lo tanto, todos los elementos conceptuales en relación a los principios básicos que orientaban la formación de alumnos franceses, fueron traspasados a los futuros alumnos chilenos." En otra parte del documento, señala: "El modelo francés imperante desde el siglo XVIII, se trajo a Chile sin pensar en las consabidas paradojas materiales y teóricas que tendría su inserción en nuestro medio, siendo una de ellas los escasos recursos de infraestructura con que contó en sus primeros años esa Academia”..(se refiere a la de pintura) Navarrete, C. En: La Academia de Pintura (catálogo) Corporación Cultural de Las Condes. Santiago de Chile, mayo 2000. 
VIII.1.3 La influencia española

Sólo cuatro autores chilenos se refieren a la existencia en Chile de un proceso enseñanza vinculado al arte: Labarca, Guarda, Pereira, y Errázuriz. Ninguno de ellos, sin embargo, alude a las bases ideológicas contenidas en dicho proceso. El análisis de la literatura y los autores que ejercieron influencia en la construcción del modelo de enseñanza en Chile, es posible concluir que dicho modelo es español.

Hubo en Chile, sin lugar a dudas, una reflexión -no masificada- acerca de la noción de arte y enseñanza, en la que las ideas de dos importantes figuras desempeñaron un papel relevante: Campomanes $\mathrm{y}$ Palomino.

\section{VIII.1.4 La influencia de Palomino y Campomanes en Chile}

Fueron las ideas difundidas en el siglo XVIII, las que ejercieron influencia en la construcción de una base política e ideológica asociada a la enseñanza y el arte en Chile. El resultado de esta investigación pone a Manuel de Salas como el ejecutor de la implantación de dichas ideas.

Palomino para la enseñanza del arte (término que me permito emplear ya en su concepción moderna) y Campomanes para el destino de dicha enseñanza. En efecto, el modelo metodológico que se emplea en Chile para entender y enseñar el concepto de dibujo y aplicarlo a variados campos del conocimiento, proviene de las lecturas que realizó De Salas de la obra Escala Optica de A. Palomino. Si bien podemos 
afirmar que las ideas de Palomino pudieron configurarse con aquellas propias del renacimiento italiano, como las de Vignola, Leonardo, Durero y Marolois entre otros, no es menos cierto que aquí fueron recibidas directamente desde España, no de Italia y a una distancia de 60 años de la primera edición de la Escala Optica (1715), es decir neoclásico y barroco, y a más de 250 años del renacimiento italiano.

Esta influencia permaneció hasta la muerte de De Salas, debido a que ejerció fuerte influencia en la creación del Instituto Nacional y este organismo, a su vez, fue la base que permitió la creación de otras instituciones de menor tamaño pero igual importancia. Es decir, las ideas y estructura que orientaron la creación de la Academia de Pintura, la Escuela de Artes y Oficios y los cursos de ornamentación, arquitectura y escultura, contenían el arrastre de las ideas de los primeros años del siglo XIX.

En cuanto al destino de la enseñanza, las ideas contenidas en el Discurso para la educación popular de los artesanos de Pedro Rodríguez Campomanes, fueron las que guiaron la implantación de la idea de educación popular en Chile. Estas ideas persistieron hasta 1847 con la creación de la Academia de Pintura y se incluyeron en su reglamento. Eliminado de la Academia un curso sobre dibujo técnico y claramente centrado ahora el dibujo en la idea de "figura humana" aplicado a las Bellas Artes, la Academia dejó -no obstante- un espacio abierto para el ingreso de los "supernumerarios", es decir aquellos alumnos que deseen estudiar dibujo "para dedicarse a otros 
ramos" $^{, 29}$. Esos alumnos supernumerarios -artesanosserían traspasados luego a la Escuela de Artes y Oficios. Es obviamente una idea basada en Campomanes la que orienta los contenidos de esta escuela que al correr de los meses comenzó a recibir fuertes influencias -ahora si-francesas.

\section{VIII.2. Dos aportes de Manuel de Salas al dibujo en Chile}

Como ya he señalado incansablemente, la noción de arte, artesanía y dibujo artístico, en tiempos de la colonia y los primeros años de la era republicana en Chile, eran conceptos bastante desapegados al significado que le otorgamos hoy. Sin embargo, en Europa, dichos conceptos, si bien se han ampliado, ya estaban estructurados bajo la noción de Bellas Artes, similar a la que hoy conocemos. Esta observación pretende contextualizar las conclusiones, debido a que el "dibujo" como materia de enseñanza, orientado a los artesanos, tenía una aplicación ciertamente artística, en el entendido que el artesano ejercía "arte".

Dicho lo anterior, puedo señalar que, fundamentalmente son dos los aportes que Manuel de Salas ejecutó en el ámbito del dibujo y que permitió el desarrollo directo e indirecto de esta materia en los años posteriores:

VIII.2.1 Crea en Chile el primer curso de "dibujo del natural" y una metodología para su enseñanza

Manuel de Salas, ejerce en su Academia una noción de enseñanza a base de la unión de materias que de manera inédita en Chile reúne a la aritmética, la

29 Ver VII.3 Reglamento de la Academia de Pintura, en este documento. 
geometría y el dibujo. En este modelo de trabajo los estudiantes de la Academia de San Luis que ejercían como artesanos, debían -de acuerdo al reglamentoaprobar un curso de dibujo que les permitía acceder a la tercera etapa denominada "maestro" (de artesanos). Este requisito fue idéntico al que según De Salas se introdujo en la Academia de San Fulgencio de Murcia en $1783^{30}$, se trata entonces de un modelo de trabajo orientado a una enseñanza para artesanos que ya estaba probado en escuelas de similar tipo, aunque la literatura sobre esta academia española para artesanos no la registra con particular acento. En la Academia de San Luis, las clases se realizaban en forma gratuita y en horario vespertino, según señala el mismo reglamento en su artículo $14^{\circ}$. Tal vez por la necesidad de atender a los aprendices fuera de sus horas de trabajo, la Academia optó por ofrecer el curso de dibujo en la noche. Dependiendo de su especialidad, el estudiante debía inscribir un curso de aritmética y(o) geometría en concordancia con el modelo español, algunas de cuyas ideas ya había expresado Campomanes. De esta forma, los artesanos alarifes, talabarteros, mineros, sombrereros, plateros y otros artesanos especialistas, debían darle mayor o menor importancia a alguna de estas disciplinas dependiendo de sus necesidades profesionales ${ }^{31}$.

$30 \mathrm{Al}$ respecto, dice Manuel de Salas "Ya esta ciudad (Murcia), pidió una cosa semejante y que se ordenase que no sean admitidos sin examen de dibujo a las maestrías de las artes que requieren estos principios...”. M. de Salas. Informe sobre la Academia dirigido al presidente interino don José de Santiago Concha. Abril 10 de 1801.

31 Un curso de química se incorpora a la Academia hacia el final de su existencia. Esta disciplina, que fue fundamental para el financiamiento de la Academia y que no pudo incorporarse por falta de profesores, apoyaría a la minería en tanto se incorporaba al plan de estudios de minerología y era útil para el gremio de fundidores y campaneros. La carencia del ramo, fue motivo de roces con 
El curso de dibujo del natural, implicaba entonces la representación figurativa de un modelo natural ${ }^{32}$, ya sea mediante el empleo de modelos tridimensionales o bien, dibujando paisajes o escenas de la calle. Tal como lo señalé antes, la carta de 1801 dirigida a José de Santiago Concha, Manuel de Salas confiesa haber adquirido para ese fin un conjunto de modelos, antes del inicio de la Academia. No obstante, en otra carta dice:

$$
\begin{aligned}
& \text { "Como en los principios de un } \\
& \text { establecimiento es difícil proporcionar } \\
& \text { todos los artículos que deben constituirlo, } \\
& \text { se empezó por el estudio del dibujo al } \\
& \text { natural..."33 }
\end{aligned}
$$

Esto implica que la noción de "dibujo del natural", es amplia y no necesariamente regida por una convicción metodológica, sino más bien por una carencia económica. No obstante es posible pensar que los "modelos", eran entendidos como objetos que contenían datos para la comprensión de problemas y conceptos de la representación.

Esta forma de trabajo de representación gráfica, implica desde ya un aporte metodológico y teórico a una noción de enseñanza del dibujo. Junto a lo

el Tribunal de Minería, uno de los organismos coloniales que financiaban a la Academia de San Luis.

32 No de la naturaleza, que podría entenderse entonces como un dibujo de paisaje.

33 Informe de M. de Salas al rector de la Real Universidad de San Felipe, acerca de un profesor de la Academia de San Luis que pretende la Cátedra de Matemáticas en dicha Universidad. Noviembre 16 de 1802. 
anterior, es necesario señalar que Manuel de Salas establece otro aporte relevante, inédito hasta ese momento en Chile: el dibujo puede enseñarse adoptando un modelo instruccional, una metodología, lo cual implica la necesidad de expertos como maestros y la aplicación de un plan sistemático de instrucción. Este sistema, que se puso en práctica con el curso de dibujo en la Academia de San Luis que sólo duró 16 meses, permitiría dictar el curso cuantas veces fuera necesario repitiendo sus contenidos con la menor variación de metodologías y por supuesto respetando sus objetivos sin importar el profesor que llegara.

\section{VIII.2.2 Incorpora en la enseñanza la relación entre arte (dibujo) y ciencia}

La asociación entre dibujo y pintura era obvia por la práctica habitual del pintor y particularmente en aquel que enseña a sus discípulos ${ }^{34}$, sin embargo no lo era al momento de hablar enseñanza o instrucción pública, en donde sólo se enseñaba dibujo, no pintura.

La desvinculación entre dibujo y pintura en un sistema de enseñanza orientado a un público que no necesariamente pertenecía al mundo del arte, puede parecernos muy natural. Lo que si pudo y aún puede resultar extraño de comprender a simple vista, es la vinculación entre arte y ciencia a fines del siglo XVIII en Chile, más específicamente entre dibujo, como

\footnotetext{
34 Pereira Salas identifica a dos artistas que ya, hacia 1652, realizaban clases de pintura a sus ayudantes y discípulos. Se trata de Francisco de Escobar y Damián Muñoz. Los casos de enseñanza de arte son pocos y mal documentados. Pereira Salas. Op. Cit., p 64
} 
parte del área del arte y la geometría, como parte del área científica.

En su Representación al consulado sobre la necesidad de establecer un aula de matemáticas de fecha 1 de diciembre de 1795, Manuel de Salas vincula dibujo con arte y lo separa de la enseñanza de la geometría, pero manteniendo la relación entre todos estos conocimientos. Es aquí que se hace relevante el pensamiento de Antonio Palomino en esta idea, al que me volveré a referir en el punto subsiguiente. La enseñanza sistemática del dibujo fue entonces una propuesta destinada a acercar la práctica de la representación al arte, pasando obviamente por un sistema de trabajo vinculado al perfeccionamiento gremial y a la enseñanza de $\operatorname{artesanos}^{35}$, en donde la enseñanza de las ciencias era primordial. El postulado de Manuel de Salas, se apoyaba en la idea de mezclar (transversalizar) conocimientos y destrezas para obtener artesanos con alta especialización en dibujo, que requerían además de conocimientos elementales de química y matemática. Esos conocimientos podían favorecer además a quienes -como él-se inclinaban por la práctica del arte.

\section{VIII.3. Una casualidad y el curso de dibujo}

¿Qué tan planificada y exitosa fue la iniciativa de Manuel de Salas en torno al dibujo? Latente en De Salas la idea aprender a dibujar, busca los resquicios para incorporar esta disciplina a un plan de formación sistemático. La gran oportunidad llega cuando el profesor Martín Petri, visita Chile en tránsito al Perú.

$35 \mathrm{Me}$ refiero nuevamente al ya mencionado Campomanes. 
Este hecho ocurre apenas es aceptada por el rey, la idea de crear la Academia de San Luis. Petri se incorpora a la Academia, pero finalmente su estadía es efímera. Luego de unos pocos meses, sigue rumbo a Lima y es reemplazado aquí por Ignacio Fernández Arrabal, quien asume en forma interina.

En total el curso de dibujo dura 16 meses. Resulta imposible saber el destino de la idea de Manuel de Salas, de no haberse cruzado de manera fortuita con un profesor de dibujo. La historia da cuenta de lo difícil que fue sostener en pie un curso de esta disciplina en Chile. Sólo es posible observar dicha materia incluida en un plan de enseñanza secundaria en el segundo decenio del siglo XIX y por fin incluida de lleno en el mundo de las Bellas Artes propiamente tal, 60 años después del primer intento. Durante todo ese tiempo, los profesores de dibujo fueron asumiendo su rol más por casualidad que por una doctrina o por un plan determinado.

La instalación del dibujo como ramo, en la estructura de enseñanza chilena, fue de evidente fragilidad. En el espacio de 20 años sólo se contabilizan en Chile 4 profesores de dibujo, reconocidos por las instituciones donde ejercían docencia: Martín Petri e Ignacio Fernández Arrabal, en la Academia de San Luis, entre septiembre de 1797 y diciembre de 1798; José Gutiérrez en el Instituto Nacional, en el período de fundación (1813) y Enrique Fermín (o Jennin) en el Instituto Nacional, en etapa de reorganización (1817).

Muy posteriormente y cerca de los límites de esta investigación, aparece el profesor de dibujo Luis Prieto a cargo de la Escuela de Dibujo Lineal de la Cofradía del Santo Sepulcro ${ }^{36}$ (1845) y los profesores Guettier y Maurin a cargo de los cursos de dibujo

36 Este curioso nombre ya fue explicado oportunamente en VII.2. 
de la Escuela de Artes y Oficios fundada en 1849. Esta nómina se observa con mayor claridad en el cuadro siguiente:

\begin{tabular}{|lc|}
\hline \multicolumn{2}{|c|}{ Profesores de dibujo en Chile $1797-1849$} \\
& \\
Martín Petri & 1797 \\
Ignacio Fernández Arrabal & 1798 \\
José Gutiérrez & 1813 \\
Enrique Fermín (o Jennin) & 1817 \\
Luis Prieto & 1845 \\
Profesor Guettier & 1849 \\
Profesor Maurin & 1849 \\
\end{tabular}

\section{VIII.4. Estrategia para el financiamiento de la Academia de San Luis}

Una academia que incorpore como estudiantes a un grupo importante de artesanos mayores, requería de un financiamiento igualmente importante. El fundador de la Academia de San Luis calculó que la Academia tendrá un costo de "mil quinientos pesos de una vez y 2.375 por año"37, cantidad que solicitó repetidas veces a la Real Audiencia. En la primera carta dirigida al rey acerca de ese tema, ofreció incluso, costear los gastos con sus propios ingresos. El Marqués de Avilés, protector de Manuel de Salas, acaudalado representante del rey en su rol de gobernador de la época, aporta 1400 pesos, mil provenientes del Tribunal del Consulado ${ }^{38}$ y 400 del Cabildo.

37 Carta dirigida al gobernador Avilés, por Manuel de Salas, escrita el 28 de mayo de 1797.

38 Tribunal del Consulado era la institución equivalente a una actual Cámara de Comercio, que reunía a los grandes mercaderes. 
Se urdió entonces una estrategia que permitió obtener parte de los recursos que se requerían, más no todo el dinero.

Según Miguel Luis Amunátegui en su libro Don Manuel de Salas $^{39}$, el Tribunal de Minería, que tal como ya se aclaró, era el órgano colonial que resguardaba los intereses de la corona y propiciaba los negocios de ese rubro, estaba obligado a crear por mandato de sus propios estatutos, una escuela de minerología y metalurgia, asunto que nunca había cumplido.

Como la química permite desarrollar la fundición y la mineralogía, De Salas incluye en su Academia un curso de química, con el propósito de demostrar su interés por iniciar los estudios en las disciplinas asociadas al rubro minero y de paso resolverle el incumplimiento al Tribunal de Minería, asunto que a esta institución le costaría nada menos que mil pesos al año.

De esa forma el Tribunal más próspero y acaudalado de la colonia concurrió con dineros para sostener esta iniciativa por tres años. Las cartas y memoriales -que iban y venían- tanto del gobernador como del Tribunal de Minería y finalmente del rey, demuestran la conflictiva relación entre dicho Tribunal y la Academia de San Luis. El 7 de junio de 1801 el Tribunal suspende la ayuda, lo que se confirma luego con las objeciones que hace ese organismo a Manuel de Salas, con motivo de su rendición de cuentas de la Academia, en diciembre de ese año, respecto a los dineros que se le dieron a la Academia entre 1798 y $1800^{40}$. En el documento de objeciones, se justifica la suspensión del aporte de mil pesos anuales, lo que implicaba en la práctica el cierre paulatino de la Academia. Tanto los documentos de la época, como la literatura posterior explican con poca claridad las razones por las cuales el curso de química

39 Santiago de Chile, Imprenta Nacional, 1895; 298 páginas.

40 Según consta en la real Orden del 31 de enero de 1798, número 14 
en la Academia nunca se dictó, pese a que De Salas finalmente habría encontrado un profesor para ese ramo.

Por otra parte, la crisis que se vivía en España en esos momentos, hizo desatender la obligación del Tribunal de Minería respecto a sus estatutos. A esas alturas, el organismo no estaba interesado, ni económica ni políticamente en dejar en Chile una mano de obra preparada para la explotación minera y el desarrollo de esa industria. Se trataba de mantener el control político, administrativo y financiero de todos los recursos estratégicos, incluida obviamente la minería. El rey, por medio de sus ordenanzas, había prohibido que se cruzaran los intereses financieros de la corona con aquellos de los mercaderes locales. Se trataba, en buenas cuentas, de no permitir el desarrollo de una oligarquía chilena. Dice al respecto Salazar:

"Naturalmente, la propensión de las burguesías coloniales a privilegiar la acumulación local por sobre la nobleza imperial anunciaba líneas de quiebre $y$ fisuras significativas en los conceptos universales sobre los que descansaba y se sostenía el orden politico del Imperio." ${ }^{41}$

Entre julio de 1796 y diciembre de 1800 Manuel de Salas recibió para la Academia de San Luis, la suma de seis mil setenta y seis pesos, con cinco y medio reales. La estrategia del curso de química -que nunca existió- le había dado frutos.

41 Salazar, Op. Cit., P. 80. 


\section{VIII.5. Una manera distinta de enseñar}

Manuel de Salas crea en Chile por primera vez en 1975, una forma de enseñanza distinta a las escuelas de primeras letras y los convictorios religiosos, también llamados colegios ${ }^{42}$ que proliferaron en el período colonial sudamericano en general y chileno en particular. Dicha forma de enseñanza ocurrió en nuestro país con la influencia de un modelo instruccional que tiene como objetivo, en la base, las ideas de Campomanes.

Puedo señalar que De Salas, comienza a incubar la idea de una academia politécnica, según el modelo que observa personalmente en Cádiz entre 1782 y 1783 y otros de los que se entera por sus lecturas de fechas anteriores y que logra poner en el papel a fines del siglo XVIII, exactamente el 1 de diciembre de 1975. Este modelo rompe con el ejercicio tradicional de enseñanza, ejercida en Chile hasta entonces por el imperio español y la iglesia católica y que Labarca califica, tal como ya se dijo en el capítulo I (I.6.1), como un excelente medio para la dominación y sometimiento de los indígenas ${ }^{43}$. La idea de De Salas, consistía en formar una capa de artesanos mayores, el equivalente a un actual técnico con formación superior. Esta idea se perfecciona con la lectura de uno de sus inspiradores, el ya mencionado Campomanes, al que menciona insistentemente en la Memoria leída en el Tribunal del Consulado el 12 de enero de $1801^{44}$. Las ideas de De Salas son análogas a las que el autor español expuso en 1775, es decir 26 años antes, particularmente la idea de entregar educación de primeras artes, letras y

42 En su acepción española (jesuita) el colegio era la denominación para la institución de educación destinada a alumnos en régimen de "internado".

43 Labarca. Op. Cit., p. 52

44 Salas E., J. Op. Cit. Tomo I, página 216. También en Archivo Nacional, Fondos Varios Vol. 275. El lector puede remitirse además a lo ya dicho sobre este autor español en V.3 de este documento. 
matemáticas a quienes se desempeñaban en oficios menores y mayores, es decir artesanos. Queda claro entonces que compartiendo el tronco común con el español, las ideas del chileno comprendían para los artesanos, la conformación de gremios para quienes ejercían distintas disciplinas en la artesanía y un rango mayor para quienes contaban con estudios especializados. El español, en cambio, defendió la idea del ejercicio libre de la artesanía al margen de la gremialización de las actividades. No obstante, ambos intelectuales, manifestaron en la base de sus ideas, dos intereses claros y en los cuales concuerdan: un interés por el establecimiento de un sistema amplio y normado para la entrega de conocimientos básicos a modo de enseñanza elemental y popular, entendido esto como herramienta de desarrollo y progreso, y un interés por el desarrollo del conocimiento especializado en el desempeño de los oficios. En síntesis: la profesionalización de la práctica laboral.

Ya manifestamos la idea que el modelo instruccional desarrollado por Manuel de Salas y depositado en la Academia de San Luis, tuvo un rasgo que es pertinente repetir aquí. Me refiero a lo que en el capítulo VII denominé como principio de simetría, igual relevancia o no exclusión.

En la plataforma de ideas de Manuel de Salas, todas las disciplinas o materias son relevantes si en conjunto apuntan a un tipo de formación definida. Esta clase de formación orientada en este caso a los gremios, no permitía la existencia de exclusiones de materias o una clasificación de las instituciones ya sea por categorías (suponer que una disciplina es de más alta categoría que otra), por clase social (suponer que hay disciplinas que sólo estudia un tipo determinado de persona dependiendo de su clase) o status (suponer que hay disciplinas que otorgan más poder y estatus que otras), pese a que distinciones como estas si estaban presentes en una sociedad clasista y segmentada 
fuertemente por el estatus social. La única taxonomía posible a su entender lo establecía el tipo de enseñanza y el destino e intereses de sus educandos. De Salas lo plantea claramente ${ }^{45}$ y con ello marca una línea divisoria entre una universidad y una academia, y entre ésta y un colegio. Lo que divide precisamente estas estructuras de enseñanza, es la aplicación del conocimiento, es decir, el desempeño social y económico de la actividad. En otras palabras, para él, una academia no es menos que una universidad; simplemente es algo distinto. Esta idea toma cuerpo verdadero, sólo cuando en el periodo de la Patria Nueva se implanta la idea de crear un órgano centralizado (estatal) para la educación chilena, que bajo el nombre de Instituto Nacional, incluye diversas instituciones de la cultura en un modelo complejo; años más tarde veremos a la Academia de Pintura en este modelo.

\section{VIII.6. El Instituto Nacional: ideas de Manuel de Salas y la enseñanza transversal}

Recordemos que el Instituto Nacional nace de la unión de tres organismos de educación: La Universidad de San Felipe, el Convictorio Carolino y la Academia de San Luis. La reunión de materias diversas como matemáticas, geometría o latín se entienden como pertinentes en la nueva estructura de un Instituto Nacional (de enseñanza y cultura) en tanto esta organización posee además la estructura de un liceo y por lo mismo es la continuación lógica del Convictorio. Sin embargo, el Instituto hereda de la Academia de San Luis tres cursos que nunca estuvieron ni en la universidad ni en el convictorio

45 Carta de representación al Consulado escrita el 1 de diciembre de 1795, ya aludida innumerables veces en esta investigación. 
mencionados: botánica, química ${ }^{46}$ y dibujo. Con la permanencia de estas disciplinas, difícil de eliminar en una estructura de enseñanza republicana que pretendía ser completa y popular, Manuel de Salas extendía su influencia sobre un sistema de enseñanza liberal y transversal de tipo técnico-profesional. Parte de sus aspiraciones, en todo caso, se vieron frustradas ya que ni el desarrollo del dibujo ni la orientación de la educación hacia los gremios, tuvo una fuerte acogida en la nueva iniciativa. Logró, tal vez por inercia y por la lógica de la nueva estructura, que el curso de química que existiendo sólo nominalmente en la Academia, sí pudiera operar realmente ahora en el Instituto Nacional. Esta transversalidad se aplicó perfectamente a la enseñanza de estudiantes secundarios, pero no se trasladó completamente al sistema de enseñanza profesional. La Academia de Pintura, por ejemplo, no incorporó cursos de matemáticas ni geometría, como lo entendía De Salas, pues estaba claramente dirigida a las Bellas Artes.

\section{VIII.7. Bajo perfil del dibujo en la era republicana}

Durante el período que va desde el cierre de la Academia de San Luis (1813) hasta el término de la Reconquista en febrero de 1817 , momento en el cual se vuelve a abrir el Instituto Nacional con un curso de dibujo, no existió en Chile ningún curso de dibujo similar al que ideara Manuel de Salas en 1795 y que llevó a la práctica en 1797. Fueron 4 años de silencio para el dibujo, primero porque la creación del Instituto Nacional eliminó la posibilidad de que la iniciativa de una academia con materias que se vinculaban transversalmente prosperara y se desarrollara en Chile; en segundo lugar, la presión del imperio

46 Pese a que ya lo he señalado antes, vuelvo a insistir: el curso de química nunca llegó a

funcionar, no obstante, siempre existió en las declaraciones de Manuel de Salas y fue el pretexto para obtener el financiamiento del Tribunal de Minería. 
español que esperaba volver a controlar estas tierras, hizo que las preocupaciones más relevantes de los chilenos se centraran en el reordenamiento político que consideraba, entre otras cosas, eludir la represión. Sin embargo, apenas se reinstala un gobierno nacional en 1817 y comienza por segunda vez sus actividades el Instituto Nacional, el dibujo se dicta nuevamente por breve espacio de tiempo y quien asume dicha responsabilidad no tiene el estatus de catedrático, sino sólo de maestro.

En el Instituto, el curso de dibujo es pobre y marginal en relación con las otras asignaturas. Los profesores de esta materia no tienen continuidad en su cargo y frecuentemente, en la nómina de profesores de esta institución, el cargo de profesor de dibujo está vacante.

En síntesis, desde la independencia y hasta 1847 la creación de la Academia de Pintura en Chile, el dibujo tuvo un papel menos destacado, concentrándose su enseñanza sólo a nivel de educación básica y secundaria, y con bajo perfil. En el terreno de la práctica artística ocurre un fenómeno similar.

\section{VIII.8. Manuel de Salas impacta en las formas y contenidos de la enseñanza del arte en el siglo XIX en Chile}

El desarrollo primario de las Bellas Artes en Chile, de la mano de la enseñanza del dibujo, tuvieron definitivamente una base en las ideas de España ejecutadas aquí por Manuel de Salas entre 1795 a 1859, en forma directa primero y por su influencia después de su muerte. Iniciada en Chile una nueva institucionalidad con la independencia de España, se ejecutaron -en el ámbito de la enseñanza y el arte- diversos planes para el desarrollo de cursos, academias y escuelas. Hemos visto que Manuel de Salas participó directa e indirectamente hasta su muerte, en 1841, en diversas iniciativas sobre educación y 
cultura. El arte no le era ajeno, por lo mismo su influencia no sólo se extendió sobre el Instituto Nacional apenas fue creado, sino además sobre los cursos de arquitectura, artes y oficios, escultura y ornamentación que se fundarían encadenadamente, desde la creación de la Academia de Pintura, pocos años después de su muerte; el reglamento de dicha academia, así lo demuestra.

A partir de ese momento límite, en que finaliza esta investigación, y ya con la Academia de Pintura en marcha plena, se desarrollaron en la segunda mitad del siglo XIX, nuevas iniciativas e instituciones de enseñanza en general, de las Bellas Artes y el dibujo en particular, con nuevas influencias y personas, en nuevos contextos políticos y sociales. Esa es, justamente, la historia más conocida sobre el arte en Chile. 



\section{REFERENCIAS BIBLIOGRÁFICAS}

\section{IX.1. Autores en libros, revistas, anales, tesis y catálogos impresos}

AGUIRRE A., Imanol. Teoría y práctica de la educación artística: ideas para una revisión pragmática de la experiencia estética. Pamplona, Editorial Universidad de Navarra, 2000. 346 p.

ALEGRE, Antonio. La enseñanza de las Artes. EN: L'Academia de Santa Barbara i la Reial de les Tres Nobles Arts de Sant Carles. Aliaga, Joan (Coord.). Valencia, Universitat Politècnica de València, 2004. 365 p.

AMUNÁTEGUI Solar, Domingo. Los primeros años del Instituto Nacional: 1813-1833. Santiago de Chile, Imprenta Cervantes, 1889. $724 \mathrm{p}$.

Recuerdos del Instituto Nacional. Santiago de Chile, Ed. Universidad de Chile, 1941. $118 \mathrm{p}$.

AMUNATEGUI, Miguel Luis. Apuntes sobre lo que han sido las Bellas Artes en Chile. En: Revista de Santiago. (II). (Imprenta Chilena. Santiago de Chile): 37-47, abril 1849.

Don José Joaquín de Mora. En.: Revista de Santiago. II. (Imprenta Chilena. Santiago de Chile): 40, 1873.

Don Manuel de Salas.

Santiago de Chile, Imprenta Nacional, Tomo 1, 1895. 298 p. 
Los primeros años del

Instituto Nacional 1813-1833. Santiago de Chile, Imprenta Cervantes, $1889.724 \mathrm{p}$.

ARAÑO, G. Juan Carlos. La enseñanza de las Bellas Artes en España (1844-1980) Tesis (Doctorado en Bellas Artes).

Madrid, Editorial de la Universidad Complutense de Madrid, 1988. 544 p.

ARECHAVALA SERRANO, Marisol "et al". La Academia de San Luis. Tesis (Grado profesor de Historia, Geografía, Economía Política). Santiago de Chile, Universidad Católica de Chile, $1970.51 \mathrm{p}$.

ARNHEIM, Rudolf. Consideraciones sobre la educación artística. Barcelona, Editorial Paidós, 1993. 100 p.

AVILA Martel, Alamiro. Mora y Bello en Chile. Santiago de Chile, Ediciones Universidad de Chile, 1982. 197 p.

Reseña de la Universidad de Chile. Santiago de Chile, Ediciones Universidad de Chile, 1979. $79 \mathrm{p}$.

BELLO, Emilio. La fundación del Instituto Nacional en 1813. Discurso histórico. Santiago de Chile, Imprenta Nacional, 1863. $32 \mathrm{p}$.

BINDIS, Ricardo. La pintura chilena desde Gil de Castro hasta nuestros días. Santiago de Chile, Phillips Chilena. S.A., 1984. $221 \mathrm{p}$.

BINDIS, Ricardo. Rugendas en Chile. Santiago de Chile, editorial Los Andes. 1989, 111 p. 
BOERO L., Ernesto. Crónicas de siglo y medio del Instituto Nacional. Santiago de Chile, Ediciones Boletín del Instituto Nacional, 1963. 190 p.

CALDERON Ruiz de Gamboa, Carlos. Gobernantes de Chile: de Pedro de Valdivia a E. Frei Ruiz-Tagle. Santiago de Chile, Editorial La Noria, 1995. 82 p.

CASTRO Eugenia y CASTAÑEDA, Ema. Las artes plásticas en la educación chilena. Tesis (Título de profesora de estado en artes plásticas). Santiago de Chile, Facultad de Filosofía y Educación, Universidad de Chile, 1965. 35 p.

CELIS, Luis. El pensamiento político de Manuel de Salas. Santiago de Chile, Editorial Universitaria, 1954. 154 p.

Manuel de Salas: Pensamiento educativo en tiempos de transición. En: Revista Pensamiento Educativo, (Santiago de Chile) 34 (1):18-27, junio 2004.

CHINOY, Ely. La sociedad. $4^{\mathrm{a}}$ ed. México, Fondo de Cultura Económico, 1966. 423 p.

CICARRELlI, Alejandro. Discurso pronunciado en la inauguración de la academia de pintura, por su director D. Alejandro Ciccarelli, seguida de la contestación en verso leída por don Jacinto Chacón. Santiago de Chile, Imprenta Chilena, 1849. $27 \mathrm{p}$.

CONTRERAS, Gonzalo, OSES, Darío y ARANCIBIA, Eduardo. Universidad de Chile: 160 años haciendo historia: 1842-2002. Santiago de Chile, Editorial Universitaria, 2002. $108 \mathrm{p}$. 
COLMENARES, Germán. Las convenciones contra la cultura. Santiago de Chile, Centro de Investigaciones Barros Arana. Dirección de Biblioteca Archivos y Museos de Chile, 2006. 177 p.

De LAVALLE, José y LANG, Werner. Arte y tesoros del Perú. $3^{\mathrm{a}}$ Parte, (Pintura Contemporánea). Lima, Banco Crédito del Perú, 1979. 177 p.

De MESA, José y GISBERT, Teresa. El arte en Perú y Bolivia (1800-1840). La Paz, Universidad Mayor de San Andrés de Bolivia. Facultad de Filosofía y Letras. Centro de estudiantes. Publicaciones 4, 1966.

Historia de la pintura

cuzqueña. Vol. 1 y Vol. 2, Lima, Fundación Augusto Wiese, 1982.

De RAMON, Armando. Santiago de Chile (1541-1991): Historia de una sociedad urbana. Santiago de Chile, Editorial Sudamericana, 2000. 287 p.

Breve Historia de Chile. Santiago de Chile, Editorial Biblos, 2001. 316 p.

EGAÑA, Juan. Notas varias. En: [s.a] Almanak u ordenación del año. Santiago de Chile, Imprenta de la República. 1824. p. 90-120.

EGAÑA, Mariano. Discurso de inauguración del Instituto Nacional. Anales de la Universidad de Chile, CXXXIII, año 71. (Litografía Barcelona), 1913. 
ERRAZURIZ, Luis H. Enseñanza de la historia del arte en la educación artística escolar. En: Revista Universitaria. (58): 5560, 1997.

Historia de un arte marginal. Santiago de Chile, Ediciones Universidad Católica de Chile, 1994. 207 p.

100 años de educación artística en Chile. Informe de investigación. (Sin editar). 2 Vols. Santiago de Chile. Universidad Católica de Chile, Santiago de Chile, 1985

FACUNDO M., Alberto. El dibujo, enseñanza aprendizaje. Valencia. Universidad Politécnica de Valencia, 1999. 376 p.

FERNÁNDEZ R., Fernando. "Inauguración de la Academia de Pintura". En: Revista de Santiago. Primera época. (Imprenta chilena, Santiago de Chile) (II): 375-378. Septiembre 1848.

FERRATER Mora, José. Diccionario de filosofía abreviado. $15^{\text {a }}$ Ed. Buenos Aires, Editorial Sudamericana, 1984. 478 p.

FRONTAURA Y ARANA, José Manuel. Historia del Convictorio Carolino. Santiago de Chile, Imprenta Nacional, 1889. $82 \mathrm{p}$.

FUENZALIDA, Alejandro. Historia del desarrollo intelectual en Chile (1541-1810). Santiago de Chile, Imprenta Universitaria, 1903. $576 \mathrm{p}$.

GALAZ, Gaspar e IVELIC, Milan. La pintura en Chile, desde la colonia hasta 1981. $2^{a}$ Ed., Valparaíso, Ediciones Universitarias de Valparaíso, 1981. 399 p. 
GAY, Claudio. Atlas de la historia física y política de Chile. París, Ed. Thunot, 1854. 250 p.

GOMEZ Molina, Juan José "et al". Estrategias del dibujo en el arte contemporáneo, Madrid, Cátedra, 1999. 662 p.

GOMEZ Molina Juan José “et al". Los nombres del dibujo, Madrid, Cátedra, 2005. 576 p.

GREZ, Vicente. Antonio Smith: Historia del paisaje en Chile. Santiago de Chile, Establecimiento tipográfico de La Epoca, 1882. $83 \mathrm{p}$.

GREZ, Sergio (compilador). La cuestión social en Chile. Ideas y debates precursores (1804. 1902). Santiago de Chile, Editorial DIBAM, 1995. 577 p.

GUAMÁN Poma de Ayala, Felipe. Nueva crónica y buen gobierno. Paris: Université de Paris, Institut d'ethnologie, 1936. Edición facsimilar [manuscrito original 1613]. xxviii, 1168 [i.e. 1178] p.

GUARDA Gabriel, O.S.B.: El arquitecto de la Moneda, Joaquín Toesca, 1752-1799: una imagen del imperio español en América. Santiago de Chile, Ediciones de la Universidad Católica de Chile, 1997. 339 p.

Historia urbana del reino de Chile.

Santiago de Chile, Editorial Andrés Bello, 1978. 509 p.

HAMPE, Teodoro (compilador). Sobre la escolástica virreinal peruana: el P. Leonardo de Peñafiel, comentarista de Aristóteles (1632). En su: La tradición jesuítica en el Perú virreinal. Lima, Fondo editorial UNMSM, 1999. 344 p. 
INSTITUTO NACIONAL. Programa de dibujo lineal arreglado para los exámenes del Instituto. Santiago de Chile, Imprenta Nacional, 1860. 10 p.

Anales de la Universidad de Chile. Decretos del Gobierno. Santiago de Chile, Imprenta de los Tribunales, 1847.

Decretos del Gobierno.

Santiago de Chile, Imprenta de los Tribunales, 1848.

Decretos del Gobierno.

Santiago de Chile, Imprenta de los Tribunales, 1850.

JUAN, Jorge y DE ULLOA, Antonio. Noticias secretas de América. Buenos Aires, Editorial Mar Océano, 1953. 531 p.

LABARCA, Amanda. Historia de la enseñanza en Chile. Santiago de Chile, Imprenta Universitaria, 1939. 364 p.

MARIATEGUI Oliva, Ricardo. José Gil de Castro ("El Mulato Gil") Vida y obra del gran pintor peruano de lo libertadores. Lima (sin editorial), 1981. $282 \mathrm{p}$.

MEDINA, José Toribio. Diccionario biográfico colonial de Chile. Santiago de Chile, Imprenta Elzeviriana, 1906.1006 p.

La educación en el siglo XVIII en Chile. Santiago de Chile, Imprenta Elzeviriana, 1901.

La instrucción pública en Chile desde sus orígenes hasta la fundación de la Universidad de San Felipe. Imprenta Elzeviriana, Santiago de Chile, 1905 (v.1 textos), 492 p. 
La Real Universidad de San Felipe. Santiago de Chile, Imprenta y Litografía Universo, 1928. Tomo I texto 650 p y II Documentos. 373 p.

MÉNDEZ, Luz María. Catálogo del Archivo del Tribunal de Minería. En: Revista de Derecho de Minas y Aguas. 1: 403-405. 1990.

MENDEZ Bejarano, Mario. Historia de la filosofía en España hasta el Siglo XX. Madrid, Editorial Renacimiento, 1927. 563 p.

MILTON, John. El paraíso perdido. Madrid, Editorial Galaxia Gutenberg-Círculo de Lectores, 2005. 734 p.

MUÑOZ Hermosilla, José. Historia elemental de la pedagogía chilena. Santiago de Chile, Casa editorial Minerva (M. Guzmán Maturana), 1918. 309 p.

MUSEO NACIONAL DE BELLAS ARTES. José Gil de Castro en Chile. Catálogo exposición retrospectiva, ciclo reactivando la memoria. Santiago de Chile, Museo Nacional de Bellas Artes. Junio-Julio 1994. 52 p.

NUÑEZ, Estuardo. La narrativa moral: Marmontel. Lima, UNMSM Fondo Editorial, 1997. 267 p.

OTXOTORENA, Juan. Sobre dibujo y diseño. Pamplona, T6 ediciones, 1996. $174 \mathrm{p}$.

PALOMINO DE CASTRO, Acisclo Antonio. El Museo Pictórico y Escala Optica. Edición Facsimilar. Prólogo de Juan Cean. Madrid, Ediciones Aguilar, 1947. 1222 p.

PEREIRA Salas, Eugenio. Historia del arte en el reino de Chile. Santiago de Chile, Universidad de Chile, 1965. 497 p. 
Estudios sobre la historia del arte en Chile republicano. Santiago de Chile, Ediciones Universidad de Chile, 1992. 344 p.

PHILIPPI, Rodulfo A. Vistas de Chile. Santiago de Chile, Editorial Universitaria. 1973. 115 p.

PEREZ G., José. Historia natural, civil, militar y sagrada del Reino de Chile. (Con una nota biográfica de José T. Medina.) Tomo 1. Santiago de Chile, Imprenta Elzeviriana, 1900. 509 p.

PEASE G.Y., Franklin. Temas clásicos en las crónicas peruanas de los siglos XVI y XVII. En: HAMPE Martínez, Teodoro (comp.), La tradición clásica en el Perú virreinal. Lima, Fondo Editorial UNMSM, 1999. 344 p.

POBLETE DE ESPINOZA, Olga. Ideario de Manuel de Salas: 1754-1841: homenaje en el primer centenario de su muerte. Santiago, Ministerio de Educación Pública, 1941. 51 p.

PORCELL T., Fernando. Diversiones y juegos populares. Formas de sociabilidad y crítica social. Colchagua: 1850-1880. Santiago de Chile, Ediciones de Dirección de Bibliotecas archivos y Museos (DIBAM); LOM Editores; Centro de Investigaciones Barros Arana, 2000. 148 p.

PRIETO DEL RÍO, Luis Francisco. Muestra de errores y defectos del diccionario biográfico colonial de Chile de José Toribio Medina. Santiago de Chile, Imprenta y Encuadernación Chile, 1907. 124 p.

RIVARA de Tuesta, María Luisa. La influencia de los clásicos en la filosofía colonial peruana. Fray Jerónimo de Valera (15681625). En: HAMPE Martínez, Teodoro (comp.) La tradición 
clásica en el Perú virreinal. Lima, Fondo Editorial UNMSM, 1999. $344 \mathrm{p}$.

RODRIGUEZ CAMPOMANES, Pedro. Discurso sobre la educación popular de los artesanos y su fomento. Madrid, Imprenta de Antonio de Sancha, 1775. 480 p.

RODRIGUEZ Mendoza, Emilio. Discurso en la ceremonia de inauguración del Museo de Bellas Artes. En: Anales de la Universidad de Chile. CXXIX, $2^{\circ}$., Santiago de Chile, Universidad de Chile, 1911.

RODRIGUEZ, Hernán. Primera visión de Chile. Dibujos de la colección Germán Vergara Donoso. Santiago de Chile, Museo Histórico Nacional / Esso Chile / Morgan, 1988.

ROJAS Abrigo, Alicia. Historia de la Pintura en Chile. Libro Audio Visión (100 diapositivas +2 cassettes), Tomo I. Santiago de Chile, Banco Español-Chile 1981.

ROJAS Mix, Miguel. Imagen artística de Chile. Santiago de Chile, Editorial Universitaria, 1970. 153 p.

ROMERA, Antonio. Historia de la pintura chilena. Santiago de Chile, Editorial Andrés Bello, 1976. 224 p.

SAGREDO, Rafael y GAZMURI, Cristián (compiladores). Historia de la vida privada en Chile. $4^{\mathrm{a}}$ Ed. Tomos I y II. Santiago de Chile, Editorial Taurus, 2005. 378 p.

SAGREDO, Rafael y GONZÁLES, J. I. La expedición Malaspina en la frontera austral del imperio español. Santiago de Chile, Editorial Universitaria, 2004. 939 p. 
SALAS Errázuriz, Juan R. (compilador). Escritos de don Manuel de Salas y documentos relativos a él y su familia. Tomo 1. Santiago de Chile, Universidad de Chile, Imprenta Barcelona, 1914. $648 \mathrm{pp}$.

SALAS Lavaqui, Manuel. (compilador). Escritos de don Manuel de Salas y documentos relativos a él y su familia. Tomos 2 y 3. Santiago de Chile, Universidad de Chile, Imprenta Barcelona, 1914. 886 pp.

SALAS Neumann, Emma. Seis ensayos sobre historia de la educación en Chile. Santiago de Chile, Editorial Universitaria, 1997. $101 \mathrm{p}$.

SALAZAR, Gabriel. Construcción de estado en Chile (17601860). Santiago de Chile, Editorial Sudamericana, 2005. 550 p.

SALVATIERRA, Manuel. Escuela de dibujo lineal. En: Monitor de las escuelas primarias, Santiago de Chile. 1, (2) Septiembre de 1852.

SANFUENTES, Salvador. Reglamento de la Academia de Pintura. En: Anales de la Universidad de Chile, correspondientes al año 1849. Primera sección. Decretos de Gobierno. Santiago de Chile, Universidad de Chile, Enero de 1849 .

SERRANO, Sol. Universidad y nación: Chile en el siglo XIX. Santiago de Chile, Editorial Universitaria, 1994. 276 p.

SIEVERNICH, Gereon. América de Bry. 1590-1634. 2ª edición. Madrid, Editorial Siruela. 2000. 479 p.

SILVA Castro, Raúl. Fundación del Instituto Nacional (18101813). Santiago de Chile, Imprenta Universitaria, 1953. 31 p. 
STUARDO Ortiz, Carlos. El Liceo de Chile 1828 -1831. Santiago de Chile, Imprenta Universitaria, 1950. 146. p.

VELEZ Cea, Manuel. El dibujo del fin del milenio. Granada, Universidad de Granada. 2001. 189 p.

VICUÑA Mackenna, Benjamín. Biografía de don Manuel de Salas. Santiago de Chile, Imprenta el Mercurio, 1872.

VILLALOBOS R., Sergio. Historia de los chilenos. Santiago de Chile, Editorial Taurus, 2006. 324 p. 


\section{IX.2 Documentos electrónicos}

AA.VV. [en línea]. [2 de enero 2008]. Disponible en:http://sisbib.unmsm.edu.pe/

AA.VV. [en línea]. [4 de enero 2007]. Disponible en: http://www.bnf.fr/

AA.VV. [en línea]. [12 de septiembre 2007]. Disponible en: http://pares.mcu.es/)

AA.VV. [en línea]. [20 de julio 2007]. Disponible en: http://www.memoriachilena.cl/

FERNÁN -NÚÑEZ, (1898). Vida de Carlos III. Apéndice y notas de A Morel-Fatio y A. Paz y Meliá. [en línea]. [20 de junio 2007]. Disponible en:

http://www.cervantesvirtual.com/servlet/SirveObras/357383523

23140053754491/index.htm

FRATICOLA, Paola. La ilustración: el racionalismo cartesiano [en línea]. [15 de noviembre 2007]. Disponible en: http://www.imageandart.com/tutoriales/estetica/esteticafundamentos5.html

GARCÍA, Rafael. Promesas y peligros de las artes: Diderot, Sade, Rousseau. [en línea]. [20 de octubre 2007]. Disponible en: http://www.es/info/nomadas/2/rgalonso1.htm

LÓPEZ PIÑERO, José María. Los saberes morfológicos y la ilustración anatómica desde el Renacimiento hasta el siglo XX. [en línea]. [30 de noviembre 2007].

Disponible en:

http://www.faximil.com/descargas/estudiopinero.pdf 
MONITOR ARAUCANO. Tomo 1 (55), Santiago de Chile, jueves 12 agosto de 1813. [en línea]. [30 de noviembre 2007]. Disponible en:

http://www.historia.uchile.cl/CDA/fh_article/0,1389,SCID\%25

3D1972\%2526ISID\%253D169\%2526JNID\%253D9,00.html

Tomo 1 (56), Santiago de Chile, martes 17 agosto de 1813. [en línea]. [30 de noviembre 2007]. Disponible en:

http://www.historia.uchile.cl/CDA/fh_article/0,1389,SCID\%25

3D1972\%2526ISID\%253D169\%2526JNID\%253D9,00.html

RODRIGUEZ, Pedro Conde de Campomanes. Discurso Sobre el Fomento de la Industria Popular. [en línea]. [23 de julio 2006]:

http://www.cervantesvirtual.com/servlet/SirveObras/024616742 12913274754491/index.htm

ZAMORANO, Pedro y CORTES, Claudio. Tradición y modernidad en la pintura chilena durante la transición de siglo: el conflicto, el escenario, los protagonistas [en línea]. [4 de diciembre 2007]. Disponible en:

$<$ http://www.universumtalca.cl/contenido/index-96/zamoranocortes.html>

\section{IX.3. Periódicos}

EL ARAUCANO. $\mathrm{N}^{\circ}$ 10, Santiago de Chile, 15 de enero de 1830.

$\mathrm{N}^{\mathrm{o}} 24$, Santiago de Chile, 26 de febrero de 1831. 
$\mathrm{N}^{\circ} 33$, Santiago de Chile, 30 de abril de

1831.

LA AURORA DE CHILE. N ${ }^{\circ}$ 2, Tomo 2, Santiago de Chile, Jueves 14 de enero de 1813.

LA CLAVE DE CHILE. No 70, Tomo 2, Santiago de Chile, 15 de enero de 1829.

\section{IX.4. Documentos en el Archivo Nacional de Chile. (Sede Antigua)}

IX.4.1. Fondo Antiguo

$\mathrm{N}^{\circ} 41$

1.- Academia de Bellas Artes.- Libro de actas de sesiones. 1875 - 1876. Vol. 306. Presidente José Victorino Lastarria.

2.- Academia de San Luis.- Resolución de S. M. sobre su establecimiento. Stgo., 23 de Julio de 1805. Vol. 245.- Pieza $15^{\mathrm{a}}$ (b).- 2 fs.

3.- Dampier, R.- Colección de 22 dibujos originales al lápiz con vistas de Chile. 1826. (Obsequio de Mr. Hume). Vol. 137.

4.- Domeyko, Ignacio. Apuntes y borradores de sus trabajos científicos. Vol. 664 - 665.

5.- Ecole d'Arts et métiers. S.M.- Note demandée par le Gouvernement du Chili pour l'étabissement d'une école d'Arts et Métiers. S/f. Vol. 52. fs. y 3 cuadros. 
$\mathrm{N}^{\mathrm{0}} 44$.

1.- Domeyko, Ignacio.- Originales de su libro "La Araucanía y sus habitantes" 1845. Vol. 33.- Pieza 7a.117 pp., 1 y dos planos. (Publicado en 1845).

2.- Educación.- Informe sobre el proyecto de educación pública presentado por don Manuel de Salas. S/f. Vol. 23.- Pieza 10 a.- fs. 166. (trunco).

3.- Educación.- Plan de Estudios. S/f. Vol. 23.- Pieza $14^{\text {a }}$. 55 fs. (orígenes del Instituto Nacional)

4.- Gay, Claudio.- Borradores acerca de la fundación de las ciudades de Castro, Osorno y Valdivia. S/f. Vol. 52.- fs. 120 y 121.

5.- Gay, Claudio.- Cuadernito de apuntes geográficos y de historia natural de la región de la araucana. S/f Vol. 112.- Pieza $7^{\mathrm{a}}$.- 24 fs.

6.- Gay, Claudio.- Legajo de sus apuntes, borradores, croquis y planos de Chile austral. S/f Vol. 52.- fs. 1 a 112.

7.- Juan Fernández, Desterrados de.- Copia de la representación dirigida al Virrey del Perú por los confinados por el general Osorio a aquella isla.- 1814 . Vol. 35.- Piezas $39^{\mathrm{a}}$. Y $46^{\mathrm{a}}$.- 4 fs.

8.- Martínez de Bernabé, Pedro Usauro.- La verdad en campaña. Relación histórica de la plaza y puerto y presidio de Valdivia. 1782. Vol. 25.- Pieza 1 ${ }^{\mathrm{a}}$.- 202 pp. 
y dos croquis. (copia hecha en 1835). Véase: "Archivos Varios", Vol. 207.

9.- Martínez Farías, Manuel.- Presentación a don Manuel de Salas sobre enseñanza comercial. S/f. Vol. 24.- Pieza $38^{\mathrm{a}}$.- 2 fs.

10.- Salas, Manuel de.- Representación del síndico del Real Consulado de Santiago, sobre el estado de la agricultura, industria y comercio del Reino de Chile. 1796. Vol. 24.- Pieza 17a .- 29 fs. (incompleta y escrita a mano)

11.- Salas, Manuel de.- Representación sobre la necesidad de cultivar las artes e industrias en Chile. 1801. Vol. 23.- Pieza 24a ${ }^{\mathrm{a}}$ - 13 fs. (escrito a mano. También publicado en obra "Escritos de Don Manuel de Salas...”).

12.- Salas, Manuel de.- Expediente promovido sobre reunión de estudios.

Representación sobre la fundación de un colegio

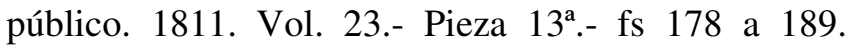
(orígenes del Instituto Nacional).

\section{IX.4.2. Catálogo Claudio Gay}

1.- Memoria de don Manuel de Salas sobre el estado de comercio, industria y agricultura de Chile.

(1796).Vol. 19. fs. 163 - 172.

2.- Copia de la presentación de don Manuel de Salas, pidiendo la creación de la Real Academia de San Luis. Vol. 28, fs. 130 - 132. 
3.- Real Orden sobre fomento de las ciencias y arte en sus dominios, en especial de la botánica. (17-IX1791). Vol. 28. fs. $138-140$.

4.- Comunicación al Tribunal de Minería sobre la creación de la Real Academia de San Luis. (1796). Vol. 41. fs. 194 - 195.

\section{IX.4.3. Catálogo Colección Ministerio de Educación}

$\mathrm{N}^{\mathrm{0}} 66$

1.- 1842 - 1877. Documentos varios. Contienen: Informes relativos a planes de estudios para el Conservatorio Nacional de Música, escuelas de Artes y Oficios y normales preceptoras y preceptores sobre el Reglamento para escuelas de Arauco y Chiloé; creación de Tribunal Médico y a otras materias, elevados por particulares al Ministerio. En: [clan; medu. v. 318].

2.- $1851 / 08$ - 1852/04. Oficios enviados a diversas Intendencias del país, a la Academia de Pintura, a las escuelas de Artes y Oficios y Normal de Preceptores, y otros servicios públicos. En: [clan; medu. v. 37].

3. 1855. Oficios enviados a diversas Intendencias del país, Academia de Pintura de Santiago y otros servicios públicos. En: [clan; medu. v. 66].

4.- 1857 - 1861. Contrato del Director de la Academia de Pintura Alejandro Cicarelli (1848 septiembre), 
proyecto del reglamento del Museo Nacional. En: [clan; medu. v. 84].

IX.4.4. Catálogo Colección Ministerio del Interior ( $\mathrm{n}^{\circ}$ 65)

1.- 1859 - 1861. Estatutos de la Asociación de Artesanos. En: [clan; mint. v. 2512]

IX.4.5. Catálogo Colección Vicuña Mackenna $\left(n^{\circ} 54,55,56\right)$

1.- DOMEYKO, Ignacio. Volumen 356.

2.- GAY, Claudio. Volumen 349 y 361.

3.- De SALAS, Manuel. Volumen 345 y 383. 



\title{
X. APENDICE
}

\section{X.1. Índice onomástico}

\author{
Alamos, Juan Crisóstomo, 106 \\ Alberti, León Battista, 68 \\ Alcalá Galeano, Dionisio, 97 \\ Aldana Fernández, Salvador, 135 \\ Aldunate Acevedo, Josefa, 127 \\ Alegre, Antonio, 71 \\ Alvarez de Acevedo Ordaz, Tomás, 92 \\ Amunátegui, Gregorio, 110, 178 \\ Amunátegui, Miguel Luis, 110, 171, 226 \\ Arancibia, Eduardo, 194 \\ Argomedo, José María, 106 \\ Arias Molina, Magdalena, 123 \\ Arís, Ramón, 106 \\ Arnheim, Rudolf, 33 \\ Atahualpa, Crisóstomo, 119, 163 \\ Baras, José Miguel, 197 \\ Bascuñán, Juan Rafael, 106 \\ Batteux, Abate Charles, 68 \\ Baumgarten, Alexander, 63 \\ Bauzá, Felipe 97 \\ Bello, Andrés, 36, 200 \\ Benavente, Juan Miguel, 106 \\ Bengoa, José, 21 \\ Berry, David, 79 \\ Bidloo, Govard (Godefridi), 144, 145 \\ Bitterich, Juan, 111 \\ Bitti, Bernardo, 86 \\ Blanco Encalada, Manuel, 32, 106 \\ Blanco, Remigio, 106 \\ Blas, Juan, 38 \\ Blooteling, Abraham, 145 \\ Bolívar, Simón, 33, 189 \\ Bouillon, A., 206, 207 \\ Brambila, Fernando, 97, 98 \\ Brunet des Baines, Claude, 208 \\ Bulnes Prieto, Manuel, 26, 203 \\ Buonaparte, Napoleón, 71
}


Buonarotti, Miguel Angel, 68

Caballero, Agustín Marcos, 103, 178

Cabezas, Lino, 43, 44

Cabezón, José, 181

Campomanes (Pedro Rodríguez Campomanes y Pérez, conde de) 152-157,

217-219, 223, 228

Cano y Aponte, Gabriel, 92

Carlos II, 133

Carlos III, 63, 70, 71, 115, 133, 168

Carlos IV, 71, 127

Carlos V, 72

Carrasco, Manuel, 197

Carrera, José Miguel, 113, 118, 181, 193

Castillo, José, 106

Cicarrelli, Alejandro, 206

Cienfuegos, José Ignacio, 106

Clemente XIV, 63

Colmenares, Germán, 95, 96

Concha Jiménez Lobatón, José de Santiago, 92, 167, 171, 220, 221

Concha y Salvatierra, José de Santiago, 92

Contreras, Gonzalo, 194

Corbalán Arias, Juan Luis, 123

Corbalán y Chirinos, Clemente, 123

Corbalán y Chirinos, María Josefa, 123, 124

Corbalán y Chirinos, Nicolasa, 123

Córdova, Germán, 181

Correa de Saa, Carlos, 106

Cronwell, Oliver, 146

Chapuis, Pedro, 180, 181

Chávez de Villafañe, Nicolás, 83

Chinoy, Ely, 36

Chirinos de Posada, Angela, 123

Chirinos, Luis, 123

D'Alembert, Jean le Rond, 65

Da Vinci, Leonardo, 167, 218

De Amat y Junient, Manuel, 92

De Artois, Conde, 148

De Atero, Miguel, 178

De Avilés y del Fierro, Gabriel (marqués de Avilés) 92, 168, 225

De Balmaseda y Censano, Beltrán Juan, 92

De Bedmar, Lucas Antonio, 134

De Benavides, Ambrosio, 92 
De Berroeta, Felix, 92

De Bry, Teodoro, 80

De Echaurren, José Francisco, 191

De Escobar, Francisco, 119, 163, 222

De Eyzaguirre, Agustín, 106, 184, 185

De Fonseca, Pedro, 76

De Góngora, Luis, 82

De Grécourt, Abate Jean-Baptiste Willart, 130, 147, 148

De Guill y Gonzaga, Antonio, 92

De Guzmán, Luis Muñoz, 172

De Jáuregui y Aldecoa, Agustín, 92, 127

De Jovellanos, Gaspar M., 65, 71

De L'Isle, Guillaume, 190

De la Carrera, Ignacio, 106

De la Cruz, Juana Inés, 82

De la Folie, Guillaume, 151

De la Lastra, Francisco, 30, 106

De la Puente, Francisco, 173, 178, 181

De la Sota, Francisco, 106

De la Vega, Inca Gracilazo, 76

De Lairesse, Gérard, 128, 131, 133, 143-145

De Lairesse, Renier, 143

De Lavalle, Antonio, 88

De Loyola, Juan Iñigo, 82

De Mesa, José, 86, 88

De Moncada, Isidoro Francisco, 86

De Mora, José Joaquín, 39, 180

De Morales, Francisco Javier, 92

De Moya, Gabriel, 38

De Ocaña, Fray Diego, 50, 119

De Oña, Pedro, 76

De Ovalle, Alonso, 50, 96

De Ovando, Francisco José, 92

De Peñafiel, Leonardo, 76

De Porres, Martín, 77

De Rebolledo, José Luis, 110

De Rezabal y Ugarte, José, 92

De Ribera, José (El Españoleto), 131, 133

De Ribera, Lázaro, 88

De Salamanca Cano, Manuel Silvestre, 92 
De Salas y Corbalán, Manuel, 26, 28, 30, 38, 39, 42, 43, 104, 106, 116, 120, $121,123,124,126,127,128-131,132,133,134,136,140,141,142,143,145$,

$146,147,149-152,153,157,159,161-163,166-169,171-173,179,180,183$, $184,186,187,191,193,195,198,199,211,212,217-223,224,225-232$

De Salas, Antonia, 127

De Salas, José, 127

De Salas, Joseph Perfecto, 123

De Salas, Judas, 124

De Salas, Manuel José, 124, 127

De Salas, Manuela, 127

De Salas, María Mercedes, 124

De Salas, Pedro José, 127

De Salas, Perfecto, 127

De Salas, Santiago, 127

De San Martín, José, 87

De Sánchez de la Barreda, Francisco, 92

De Savoie, Marie-Thérèse, 148

De Sigüenza y Góngora Carlos, 82

De Silva Bórquez, Pedro Ramón, 178

De Suría, Tomás, 97

De Tejada y Carvajal Robles, Luis, 82

De Toro y Zambrano y Ureta, Mateo, 92

De Ulloa, Antonio, 79, 132

De Ustariz de Vertizberea, Juan Andrés, 92

De Valdivia, Pedro, 112

De Varela, Jerónimo, 72

De Velasco, José Antonio Manso, 92

De Villarroel, Gaspar, 77

De Villegas, Hipólito, 102

De Vries, Jan Vredeman, 138

De Yrala, Mathías, 68

Del Pino Sánchez de Rojas, Joaquín, 92

Del Pozo, José, 86, 87, 97, 106

Del Rosario, Julián, 110

Descartes, René, 68

Diderot, Denis, 65, 67, 149, 194

Diez de Medina Vidanges, Francisco Tadeo, 92

Domeyko, Ignacio, 200

Dossier, Carlos Ambrosio, 200

Du Verdier, Gilbert, 141

Durero, Alberto, 167, 218

Echagüe, Francisco, 106 
Echagüe, José Gregorio, 197

Echeverría, Juan José, 106

Egaña, Juan, 33, 184, 191, 192, 193, 198

Egaña, Mariano, 158, 216

Elizondo, Diego Antonio, 178

Errázuriz, Isidoro, 106, 178

Errázuriz, Luis Hernán, 217

Federico I, 69

Feijoo, Jerónimo, 65, 71

Fermín, Enrique (ver también Jennin Enrique), 195, 197, 204, 224, 225

Fernández Arrabal, Ignacio, 120, 169, 178, 201, 224, 225

Fernández Garfias, Pedro, 197

Fernández Palazuelos, Manuela, 127

Fernández Palazuelos, Pedro, 127

Fernández, José María, 197

Fernando VII, 71, 90

Ferrater Mora, José, 65

Feullée, Louis, 133

François, Augusto, 207, 208

Freire, Ramón, 158

Frézier, Amadeo Francisco, 133

Frontaura y Arana, José Manuel, 115

Fuenzalida, Alejandro

Galaz, Gaspar, 104

García Carrasco Díaz, Francisco Antonio, 92

García Corbalán, Antonio, 122

García Corbalán, Domingo, 122

García y Delgado, Mauricio, 86

García, Juan, 197

Gatica, Antonio, 197

Gay, Claudio, 51, 52, 54-56, 98, 101, 200

Gazmuri, Cristián, 19

Gil de Castro, José, 82, 88, 89, 101, 102, 196 (también Mulato Gil)

Girardi, Albert, 139

Gisbert, Teresa, 86,88

Godoy, Juan, 202, 204, 214

Goicovic, Igor, 19

Gómez Molina, Juan José, 42, 45, 46

González Marmolejo, Rodrigo, 112

Gorbea, Andrés, 197

Goucourt, Abate (ver De Grécourt)

Goyena, Juan, 106 
Grétry André-Ernest-Modeste, 148

Guamán Poma de Ayala, Felipe (también Huamán) 77, 78

Guarda, Gabriel, 99, 110, 113, 114, 217

Guettier, profesor, 224, 225

Guío, José, 97

Gutiérrez, José, 194, 224, 225

Haencke, Tadeo, 97, 98

Hempe, Teodoro, 75

Henríquez, Camilo, 180

Hernández, Manuel, 181

Hernández, Pascual, 206, 207

Hével, Mateo Arnaldo, 106

Hodges. W., 81

Hogart, Williams, 68

Hondius, Hendrik, 138

Huamán Poma de Ayala, Felipe (ver Guamán Poma)

Humboldt, Alexander von, 98, 101

Hume, David, 65

Ibáñez de Segovia y Peralta, Francisco, 92

Iñiguez, José Santiago, 197

Irigoyen, Manuel, 113

Ivelic, Milan, 104

Jennin Enrique (ver Fermín, Enrique)

Juan, Jorge, 79, 132

Kant, Inmanuel, 65, 66

Kellner, Jacobo, 111

Koening, Juan Ramón, 132

Labarca, Amanda, 35-38, 110, 114, 181, 217, 228

Larraín, Diego, 106

Larraín, Joaquín, 106

Lasalle, Enrique, 106

Lavaqui, Diego, 106

Lazo de la Vega, Francisco, 123

Lebrún, Antoine-Louis, 140

Lebrún, Charles, 131, 133, 141, 143

Lebrún, Charles-François, 141

Lebrún, Corneille, 141, 142

Lebrún, Jean Baptiste, 141

Lebrún, Jean-Etienne, 141

Lebrún, JPP Citoyen, 140, 141

Lebrún, P.A (Abate), 141

Lebrún, Pierre, 141 
Lebrún, Ponce Denis, 141

Lebrún-Tossa, Antoine, 140

Lemus Barroso, Luisa, 123

Losada, Antonio, 51

Luisa, reina, 183

Malaspina, Alessandro, 87, 97

Mancheño, José Tadeo, 184

Marchant, Cristóbal, 179

Marcó Del Pont Ángel Díaz y Méndez, Casimiro, 91, 92

Mariátegui Oliva, Antonio, 89

Marín, Buenaventura, 197

Marín, Ventura, 202, 204, 214

Marmontel, Jean-François 148, 149, 150

Marolois, Samuel, 128, 131, 133, 138-140, 167, 218

Marques de Avilés (ver De Avilés y del Fierro, Gabriel)

Martínez de Bernabé, Pedro Usauro, 97

Martínez, Jusepe, 68

Martínez, Manuel, 178

Maruri, Andrés, 178

Matta, Manuel Antonio, 101

Maurín, profesor, 224, 225

Medina, Toribio, 39, 110

Medoro, Angelino, 85, 86

Méndez, Luz María, 168

Meneses, Juan Antonio, 185

Meneses, Juan Francisco, 196

Milizia, Francesco, 68

Millar, René, 19

Milton, John, 128, 130, 131, 146

Molina, Juan Ignacio, 96

Montesquieu (Carlos de Secondant, Barón de), 65

Montt, Manuel, 202, 204, 214

Monvoisin, Raymond, 203, 204, 216

Mulato Gil (ver Gil de Castro, José)

Muñoz Bezanilla, Santiago, 106

Muñoz Correa, Juan Guillermo, 19

Muñoz de Guzmán, Luis, 92, 128, 157, 172

Muñoz, Damián, 119, 163, 222

Nauman, Bruce, 45

Navarrete, Carlos, 206

Nee, Luis, 97

Niño, Luis, 83 
Nolasco y García, Pedro, 86

Núñez de Vela, Blasco, 72

Nuñez, Estuardo, 149

O’Higgins Ambrosio, 92, 127

O'Higgins, Bernardo, 89, 113, 129

Oquendo, Manuel, 88

Ortiz de Rosas, Domingo, 92

Oses, Darío, 194

Osorio, Mariano, 91, 92, 106, 113

Otxotorena, Juan, 44

Ovalle, Juan Antonio, 106

Ovidio, Publio, 140

Pablo III, 75

Palomino, Asisclo Antonio, 68, 133, 134, 136, 137, 139, 142, 217, 223

Pedro II, 206

Peña, Saturnino, 110

Pereira Salas, Eugenio, 94, 99, 119, 132, 133, 214, 217, 222

Pérez, Francisco A., 184

Petri, Martín, 103, 104, 120, 169, 178, 223-225

Phillipi, Rodulfo Armando, 54, 98, 101

Pineda, Antonio, 97

Pinto G., Aníbal, 36

Pinto Santa Cruz, Aníbal, 103

Porcell, Fernando, 200

Portales, Diego, 128

Portales, José Santiago, 106

Poveda, Lorenzo, 83

Pozzo, Andrea, 64

Prado Jaraquemada, Pedro, 106

Prieto, Luis, 206, 207, 224

Prust, Luis, 179

Quispe Tito, Diego, 84, 86

Ravent, Juan, 97

Reinoso, Jerónimo, 106

Retamal F., Julio, 19

Reyes, Blas, 196

Richardson, Samuel, 149

Riveros, José, 178

Rodríguez Ballesteros, Juan, 92

Rodríguez Brochero, Francisco, 179

Rojas Mix, Miguel, 81, 86

Rojas, José Antonio, 30, 106, 121, 125, 130, 134, 145, 212 
Rojas, Pablo, 82, 88

Rosales, Diego, 95

Rosales, Juan Enrique, 106

Rousseau, Jean-Jacques, 65

Rugendas, Johann Moritz (Mauricio), 46-48, 50, 54, 98, 200

Ruiz, Gaspar, 106

Sabatini, Francesco, 104, 178

Sagredo, Rafael, 19

Salas Errázuriz, Juan, 153, 162, 166, 179, 212, 228

Salas Lavaqui, Manuel, 121

Salazar, Gabriel, 19, 36, 89, 158, 181, 187, 227

Salinas Meza, René, 19

Sanfuentes, Salvador, 203

Santa María, José Ignacio, 178

Santo Tomás, 76

Sepúlveda, Eusebio, 197

Serrano, Sol, 194

Smith, Adam, 65

Solano, Pérez, Juan, 197

Sorolla y Bastida, Joaquín, 89

Suarez, Francisco, 76

Talavera, Manuel Antonio, 114

Talens, Jenaro, 146

Taulier, Catherine, 143

Thomson, Diego, 181

Toesca, Joaquín, 52, 99, 103, 104, 165, 169, 178

Torres, Ignacio, 106

Turín Tomás, 152

Ureta, Baltasar, 106

Urrutia, Martín, 181

Valdés, Pedro Nolasco, 106

Valera, Blas, 77

Valdivieso Larraín, Manuel, 106

Vasari, Giorgio, 68

Vial, Agustín, 106

Videla, Javier, 106

Vignola (Giacomo Barozzi de Vignola, llamado), 218

Villalobos, Sergio, 19, 91, 95, 110

Villalón, Manuel José, 178

Vitale, Luis, 110

Voltaire (François Marie Arouet, llamado), 65, 128, 149

Wood, Charles, 103 
Zapata, Marcos, 82

Zegers, Isidora, 200, 201

Zuccari, Tadeo, 68 
